UNIVERSIDADE DE SÃO PAULO

FACULDADE DE FILOSOFIA, LETRAS E CIÊNCIAS HUMANAS

DEPARTAMENTO DE GEOGRAFIA

PROGRAMA DE PÓS-GRADUAÇÃO EM GEOGRAFIA HUMANA

ANDRÉ DE FREITAS GONÇALVES

\title{
Avaliação de Território e Coremática. Aplicação ao Município de São Paulo
}

Versão corrigida. O exemplar original se encontra disponível no

CAPH da FFLCH (Centro de Apoio à Pesquisa Histórica). 
UNIVERSIDADE DE SÃO PAULO

FACULDADE DE FILOSOFIA, LETRAS E CIÊNCIAS HUMANAS

DEPARTAMENTO DE GEOGRAFIA

PROGRAMA DE PÓS-GRADUAÇÃO EM GEOGRAFIA HUMANA

\section{Avaliação de Território e Coremática. Aplicação ao Município de São Paulo}

André de Freitas Gonçalves

Dissertação apresentada ao Departamento de Geografia da Faculdade de Filosofia, Letras e Ciências Humanas da Universidade de São Paulo, para obtenção do título de Mestre em Geografia.

Orientadora: Profa. Dra. Neli Aparecida de Mello-Théry

Versão corrigida. O exemplar original se encontra disponível no

CAPH da FFLCH (Centro de Apoio à Pesquisa Histórica).

De acordo 


\section{Agradecimentos}

Quero agradecer primeiramente a minha mãe pelo apoio, carinho e atenção de sempre. Por sua incansável luta de me fazer lembrar os prazos. Ao meu pai e irmãos pela preocupação e força.

A professora Neli Aparecida de Mello-Théry, por aceitar ser minha orientadora formal. Pelo apoio, confiança e pelas sugestões fortes, que procurei aplicar da melhor forma possível.

Agradecimento especial ao professor Hervé Théry, que aceitou ser meu orientador informal. Foi seu trabalho que me inspirou a realizar essa pesquisa. Agradeço muito sua confiança, ajuda e paciência.

Ao professor Ailton Luchiari, por suas colocações e sugestões na banca de qualificação.

A professora Mónica Arroyo, por seu humanismo, apoio e ajuda efetiva em um momento difícil e por seu entusiasmo e rigor profissional.

Ao José Marcos Pereira de Araújo, por sua ajuda fundamental e amizade.

Agradecer aos meus colegas da Secretaria Municipal de Desenvolvimento Urbano, especialmente os colegas do Dipro. Em particular a José Benedito de Freitas pela ajuda na parte econômica; ao Akinori Kawata pelas informações cadastrais; a Liane Lafer Schevz e Maria Isabel Paulino pela ajuda com os dados e mapa de predominância de uso e ocupação e área construída.

Agradecimento pela preocupação, conselhos e motivação de Juliana Colli Munhoz, Fabiana Valdoski Ribeiro, André Rodrigues Nagy, Silvia Anette Kneip, Tomás Wissenbach e Vagner Bessa.

Quero também agradecer ao Hugo Leonardo de Almeida por sua colaboração nas traduções, revisões e pela paciência que teve principalmente nos últimos meses. Ao Jonas Pinheiro pela revisão e prontidão em ajudar, mesmo sob condições desfavoráveis. A minha prima Nélia pela ajuda na tradução. E agradecer a Rodrigo Matos (In memorian) pelas vezes que me mandou largar o vídeo game. 


\section{Resumo}

Em um período no qual as transformações ocorrem de maneira acelerada, com a atuação de um número cada vez maior de atores, bem como de processos gerais que refletem direta ou indiretamente nas dinâmicas locais, é preciso encontrar instrumentos de análise capazes de auxiliar na compreensão desse contexto. Mesmo sabendo que os eventos globais influenciam fortemente o local, cada vez mais as escalas menores têm adquirido mais e maiores responsabilidades, pois é no local onde as desigualdades sociais e espaciais aparecem de forma explícita. As características do período contemporâneo nos impõem o desafio de pensar e renovar as técnicas de análise. Considerando que uma das dimensões da sociedade é o espaço geográfico, e que o bom entendimento da realidade presente passa pela avaliação de nossos territórios, acreditamos pertinente o uso da avaliação de território e da coremática como formas de executar essa tarefa. Entendidos como instrumentos teórico-metodológicos, a avaliação de território e a coremática fazem parte do esforço de compreender a realidade contemporânea, emergidos da necessidade de conhecer melhor, de forma mais clara e objetiva a organização do espaço geográfico, a dinâmica territorial, como também realizar, por meio de critérios e parâmetros, uma avaliação da situação de determinado espaço. Essas técnicas de análise têm a mesma origem teórica e se complementam mutuamente. Tiveram suas primeiras formulações feitas por Roger Brunet, que liderava um grupo de geógrafos franceses que desenvolveram uma série de trabalhos e, assim, puderam aprimorá-las teórica e metodologicamente. Demonstraremos seu uso ao aplicarmos a metodologia na análise do município de São Paulo.

Palavras-chave: Avaliação de território; coremática; modelização gráfica; teoria dos Coremas; cidade de São Paulo. 


\section{Abstract}

In a period where the changes occur at an accelerated way, operating a growing number of actors and the general processes that directly or indirectly reflect the local dynamics, we need to find analytical tools that can assist in understanding these changes. Even though global events strongly influence the location, increasingly smaller scales have greater responsibilities, because it is the place where the social and spatial inequalities appear explicitly. The characteristics of the contemporary period imposes us to the challenge of thinking and renew the technical analysis. Whereas the dimensions of a society is the geographical space, and good understanding of current reality involves the evaluation of our territories, we believe to be pertinent using the appropriate evaluation of territory and coremática as a way to achieving this task. Understood as theoretical methodological tools, the evaluation of territory and coremática are part of efforts to comprehend the contemporary reality, emerged from the need to better understand, more clearly and objectively, the organization of geographical space and the territorial dynamic and be able to, by means of criteria and parameters, an evaluation of the situation of a certain space. These analysis techniques have the same theoretical source and they complement each other. Their first formulations were composed by Roger Brunet, who led a group of French geographers who developed a series of investigations and therefore could improve them theoretically and methodologically. We will validate its use by applying the methodology in the analysis of São Paulo City.

Key words: Evaluation of territory; coremática; graphical modelin; theory of corema; São Paulo City. 


\section{SUMÁRIO}

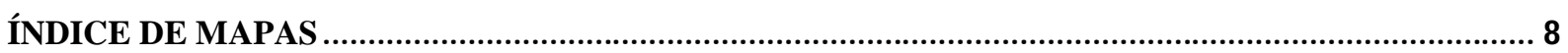

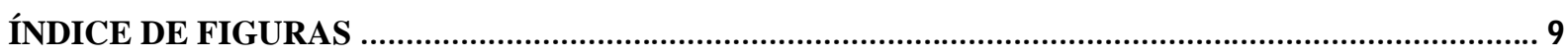

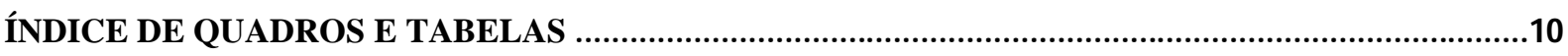

ÍNDICE DE GRÁFICOS

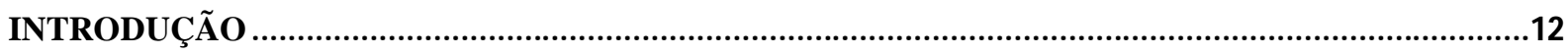

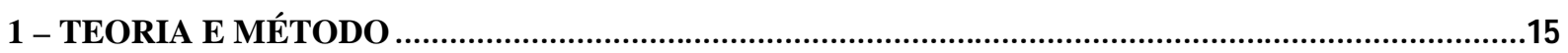

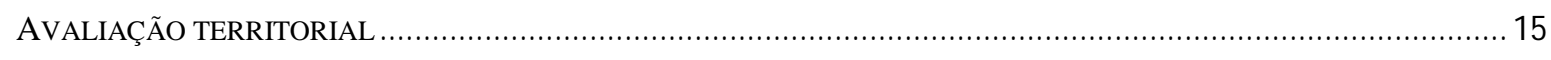

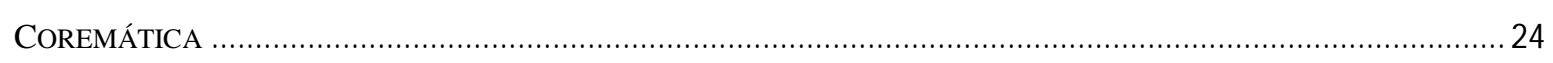

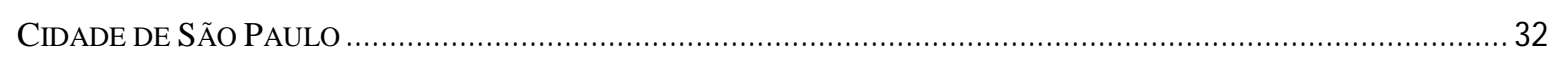

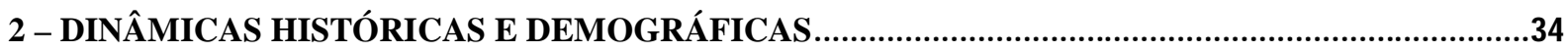

CIRCULAÇÃO, GÊNESE DO TERRITÓRIO E DINÂMICA DEMOGRÁFICA ……......................................................... 35

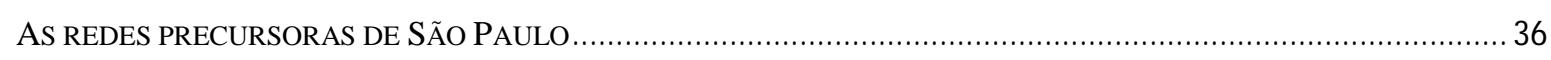

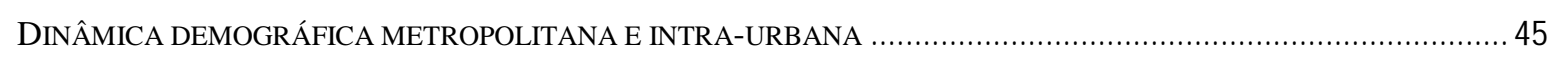

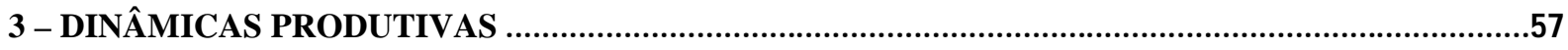

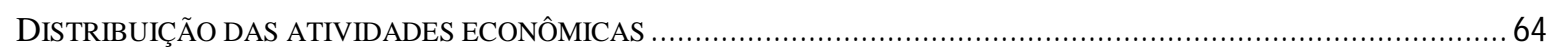

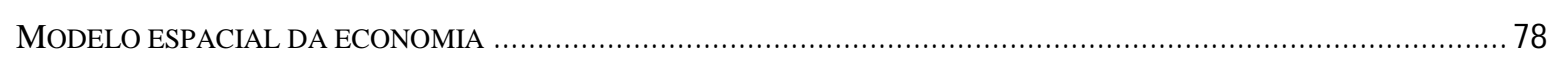

4 - DINÂMICAS URBANAS

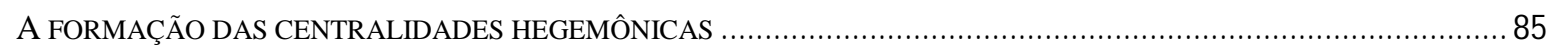

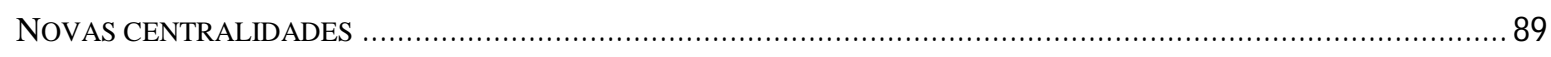

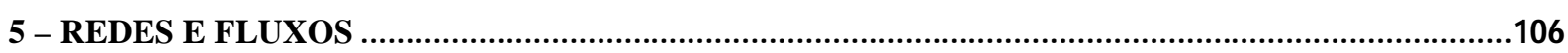

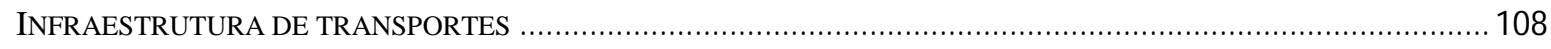

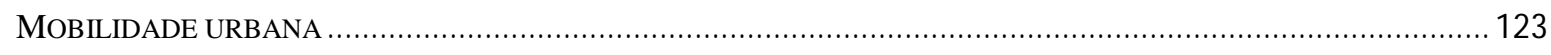

6 - MODELIZAÇÃ̃o GRÁFICA DA CIDADE DE SÃO PAULO .............................................134

CONSIDERAÇÕES FINAIS

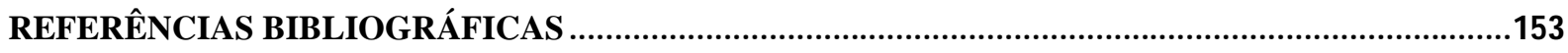




\section{Índice de mapas}

Mapa 1 - Os principais caminhos em fins do século XVIII Página 39

Mapa 2 - População do Município de São Paulo, 1950-1970 Página 48

Mapa 3 - População do Município de São Paulo, 1980 - 2000 Página 49

Mapa 4 - Taxas de crescimento anual da população, Município de São Paulo Página 51

Mapa 5 - Mapa - densidade demográfica 2010, Página 53

Mapa 6 - Mapa população 2010 Página 54

Mapa 7 - Mapa Tipologia dos distritos, segundo comparação das taxas de crescimento da população 1991/2000 e 2000/2010 Página 55

Mapa 8 - Uso do Solo Predominante - Indústria, 2006 Página 66

Mapa 9 - Variação da área construída da indústria, 1991/2010 Página 68

Mapa 10 - Tipologia dos distritos segundo variação da área construída e do terreno da indústria 1991/2010 Página 69

Mapa 11 - Variação do emprego no setor da indústria, 1996/2006 Página 71

Mapa 12 - Distribuição do emprego no setor da indústria, Página 72

Mapa 13 - Distribuição do emprego no setor de serviços, Página 75

Mapa 14 - Variação do emprego no setor dos serviços, 1996/2006 Página 76

Mapa 15 - Complexo Corporativo Metropolitano Página 88

Mapa 16 - Planos e projetos de intervenção urbana, 2012 Página 101

Mapa 17 - Planos e projetos de intervenção urbana e rede de alta capacidade, 2012 Página 103

Mapa 18 - Planos e projetos de intervenção urbana e rede de alta capacidade até 2025 Página 104

Mapa 19 - Sistema de transporte coletivo, 2012 Página 112

Mapa 20 - Volume de passageiros, 2011 Página 118

Mapa 21 - Anéis viários e estrutura rodoviária, 2012 Página 121

Mapa 22 - Regionalização de São Paulo Página 125

Mapa 23 - Fluxo total de viagens por Regiões de São Paulo, 1997 Página 130

Mapa 24 - Fluxo total de viagens por Regiões de São Paulo, 2007 Página 131 
Mapa 25 - Variação do número de viagens por Regiões do Município de São Paulo, 1997/2007 Página 133

Mapa 26 - Proteção ambiental, 2012 Página 135

Mapa 27 - Mancha da área urbanizada Página 136

Mapa 28 - Viagens produzidas pelos municípios da Região Metropolitana de São Paulo, 2007 Página 137

\section{Índice de figuras}

Figura 1 - Sistema de produção e dominação do espaço Página 26

Figura 2 - Resultados atingidos pela colonização paulista em fins do século XVIII Página 41

Figura 3 - Rede de bondes e trens da cidade de São Paulo, 1913 e 1916 Página 43

Figura 4 - Pontos de referência Página 79

Figura 5 - Localizações específicas Página 80

Figura 6 - Três setores e quatro áreas estratégicas Página 82

Figura 7 - Regiões de escritórios Página 93

Figura 8 - Demanda por transporte coletivo, Região Metropolitana de São Paulo, 2011 Página 109

Figura 9 - Esquema teórico do Plano de Avenidas Página 120

Figura 10 - Limite de São Paulo Página 138

Figura 11 - Limite Página 139

Figura 12 - Barreira Página 140

Figura 13 - Rede Página 141

Figura 14 - Centralidade Página 143

Figura 15 - Eixo Página 144

Figura 16 - Indústria Página 145

Figura 17 - Densidade Página 145

Figura 18 - Fluxo Página 146 
Figura 19 - Pressão Página 146

Figura 20 - Conflito Página 147

Figura 21 - Elementos de composição da modelização gráfica Página 148

Figura 22 - Modelo da cidade de São Paulo Página 149

\section{Índice de quadros e tabelas}

Quadro 1 - Coremas propostos por Brunet Página 27

Tabela 1 - Estabelecimentos e Empregos Formais por Subsetor de Atividade Econômica, Brasil, Região Metropolitana e Município de São Paulo, 2010 Página 59

Tabela 2 - Participação do Município e Região Metropolitana de São Paulo no Valor Adicionado Fiscal do Estado de São Paulo, 2009, Página 61

Tabela 3 - Valor Adicionado por Setores de Atividade Econômica a Preços Correntes, Unidades da Federação e Município de São Paulo - 2009 Página 62

Tabela 4 - Estoque de locação e novos estoques de escritório Página 95

Tabela 5 - Rede de metrô em grandes cidades, 2012 Página 117

Tabela 6 - Evolução da Divisão Modal e da Taxa de Motorização, Região Metropolitana de São Paulo Página 123 


\section{Índice de gráficos}

Gráfico 1 - Imigrantes no Brasil e no Estado de São Paulo, 1872-1972 Página 46

Gráfico 2 - Taxas de crescimento anual da população residente, Região Metropolitana e Município de São, Paulo, 1940-2010 Página 47

Gráfico 3 - Participação do Produto Interno Bruto Brasileiro, 1999 a 2009 Página 63

Gráfico 4 - Novos estoques, Página 91

Gráfico 5 - Demanda de passageiros nos ônibus municipais, Município de São Paulo, 2002 a 2011 Página 110

Gráfico 6 - Demanda de passageiros de ônibus intermunicipal, Região Metropolitana de São Paulo, 2002 a 2011 Página 115

Gráfico 7 - Demanda de passageiros no metrô e trem, Município de São Paulo, 2002 a 2011 Página 116

Gráfico 8 - População e emprego, Regiões do Município de São Paulo, 1997/2007 Página 126

Gráfico 9 - Viagens produzidas, Regiões do Município de São Paulo, 1997 Página 127

Gráfico 10 - Viagens produzidas, Regiões do Município de São Paulo, 2007 Página 128 


\section{Introdução}

Esta pesquisa foi motivada principalmente pela aproximação que tivemos da teoria dos coremas, quando da participação no projeto do Atlas Seade da Economia Paulista, no qual foi possível acompanhar de perto o trabalho de Hervé Théry (2006), responsável pelo capítulo "Chaves para a leitura do território paulista", apresentando um modelo gráfico do estado de São Paulo. Posteriormente, tivemos participação em outro projeto denominado Metamorfoses paulistanas: atlas geoeconômico da cidade, onde são apresentados "Modelos gráficos da competitividade paulistana” (THÉRY, 2012), aplicando a modelização gráfica ou coremática para cidade de São Paulo. Em seguida, cursando a disciplina de pós-graduação “Avaliação Prospectiva dos Territórios”, Théry apresentaria a segunda metodologia de análise sobre a qual versa o nosso trabalho. A avaliação de território implica uma análise que considera uma visão prospectiva dos territórios por parte do pesquisador. A ideia está implícita no método e se constitui parte da avaliação, por isso, seguindo seus principais formuladores, chamaremos simplesmente de avaliação de território. A coremática, por sua vez, é apresentada por alguns autores como modelização gráfica. Neste trabalho trataremos como sinônimos.

Sabemos que o diagnóstico é uma ferramenta de análise básica utilizada em diversos tipos de trabalho e por diferentes campos do saber, assim como o mapa, que não é uma ferramenta de uso exclusivo do geógrafo, mas que este tem a obrigação de mostrar como deve ser feito e como deve ser utilizado, de modo a não reduzi-lo a mera ilustração. O uso dessas ferramentas para compreender a organização do espaço geográfico e a dinâmica do território é frequente tanto na esfera da administração pública quanto na iniciativa privada, em estudos técnicos e acadêmicos. Quando desenvolvemos um diagnóstico de determinado espaço geográfico e representamos seus objetos, suas estruturas, seus movimentos e sua organização por meio da cartografia, podemos potencializar este trabalho com os instrumentos teórico-metodológicos da avaliação de território e a coremática. A cartografia e a coremática são complementares. "Os dados qualitativos e quantitativos extraídos da cartografia temática contribuem para a apreensão do espaço. Porém, sua síntese e os principais elementos da organização espacial são revelados pela modelização gráfica" 
(PANIZZA, 2004, p. 55). A avaliação de território é, sobretudo, um diagnóstico, porém avança em termos de procedimentos metodológicos e adequação teórica. É imprescindível o fundamento teórico dentro do processo de avaliação, assim como o rigor metodológico, por meio de uma série de práticas a serem adotadas, estabelecendo critérios e parâmetros por meio da experiência e herança científica.

O objetivo do trabalho é apresentar a avaliação de território e a coremática demonstrando que são complementares no processo de análise de um território, da mesma maneira que o diagnóstico e o mapa, mas que representam um avanço nos estudos, contribuindo para uma melhor apreensão do espaço geográfico no período atual. Aplicaremos os procedimentos teórico-metodológicos das duas técnicas ao município de São Paulo, que será analisado de uma forma ampla, ressaltando alguns aspectos importantes de sua realidade. Não se pretende aqui um diagnóstico exaustivo, mas objetivo e conciso conforme apresenta a metodologia utilizada.

Procuramos resgatar a ideia de síntese que é tão característica da Geografia. Algo simples, direto e comunicativo, mas que não prescinde do rigor teórico e metodológico. A modelização gráfica não dispensa a crítica social; considera o tempo no processo de análise; os fatos e processos sociais; trabalha e pondera o conflito; as continuidades e descontinuidades; o risco e o choque. Não procura estabelecer ou indicar uma harmonia suprema e não pretende construir um modelo eterno. Este é provisório e permanece efetivo até se criar um novo modelo que possa substituí-lo.

É preciso saber avaliar os territórios, encontrar as perguntas importantes a serem feitas e respondê-las. Identificar as figuras-chave que representam as estratégia e dinâmicas essenciais, estruturas elementares do território. É mister conhecer o território em suas várias faces, os seus movimentos, os atores responsáveis por seu movimento, suas características próprias e específicas, sua formação, seus processos, etc. para compreender o presente em busca de uma ideia de futuro.

No primeiro capítulo, abordaremos as questões teóricas e metodológicas da avaliação de territórios e da coremática. Os preceitos teóricos, seus formuladores e apresentação dos instrumentos em si. Ainda neste capítulo, falaremos da complexidade de se analisar a cidade de São Paulo no período atual. 
No segundo capítulo, entraremos no estudo de caso da cidade, iniciando com a análise das dinâmicas históricas e demográficas, a partir da perspectiva da circulação e gênese do território, descrevendo o processo de surgimento do que hoje conhecemos como uma das maiores metrópoles do mundo, suas redes precursoras até a dinâmica demográfica intraurbana e metropolitana.

No terceiro capítulo, analisaremos as dinâmicas produtivas da cidade, a importância da indústria e a força dos serviços, bem como todo o processo de reestruturação econômica e produtiva por que passou a cidade. Também estão aqui presentes as transformações recentes na estrutura produtiva e dos arranjos espaciais formados por sua interação com o território da cidade, apontando para seu movimento dos últimos anos, partindo da distribuição das atividades econômicas até alcançar um modelo espacial da economia.

No quarto capítulo, reconheceremos a ação dos atores locais na transformação da cidade, na formação de centralidades hegemônicas que exercem grande força de atração econômica e de pessoas, sendo símbolo de controle econômico e territorial. Sua influência ultrapassa os limites municipais, alcançando o país inteiro. Também, procuramos reconhecer novas centralidades, a indicação dessa formação por meio de dados concretos e por um conjunto de projetos instaurados na cidade.

No quinto capítulo, analisamos as redes e os fluxos da cidade, por meio da caracterização de sua infraestrutura de transportes e apresentando as questões referentes à crise de mobilidade urbana. Buscamos levantar o estado atual da rede de transporte e os projetos para o futuro, que envolvem diferentes atores e escalas de governo. Sobre a mobilidade, procuramos apresentar de maneira ampla os deslocamentos na cidade e as suas principais características por meio da mais importante pesquisa produzida sobre o tema, a pesquisa origem e destino.

No último capítulo, modelização gráfica da cidade de São Paulo, apresentamos o procedimento de modelização que resultará em um modelo gráfico, o qual terá como base o diagnóstico realizado.

Fecharemos, então, com as considerações finais, onde apontaremos para os resultados alcançados com o uso do método. 


\section{Teoria e método}

\section{Avaliação territorial}

O geógrafo francês Roger Brunet é responsável pela formulação da coremática e da avaliação de territórios. A primeira surgiu no início dos anos 1980, ao passo que a segunda começou a ser utilizadaa partir dos anos de 1990. Outros geógrafos e pesquisadores participaram de seus desenvolvimentos e aprimoramentos teórico-metodológicos, de maneira mais ativa com trabalhos criados dentro do grupo GIP RECLUS.

A criação do Groupement d'Intérêt Public (GIP) chamado de Réseau d'Etude des Changements dans les Localisations et les Unités Spatiales (RECLUS), do Ministério da Pesquisa e Tecnologia da França, teve participação de outros ministérios e diversos organismos públicos como Centre National de la Recherche Scientifique (CNRS) e o Office de la Recherche Scientifique et Technique Outre-mer (ORSTOM) que é o atual Institut de Recherche pour le Développement (IRD). Universidades e autoridades locais também fazem parte da grande rede de pesquisa que se formou, somando algo em torno de 25 organizações de pesquisa.Seu ano de inauguração foi 1984. Os principais objetivos eram trabalhar sobre a dinâmica dos territórios e desenvolvier duas grandes coleções: a Géographie universelle e Atlas de France. Porém,outros tantos livros foram públicados. Como exemplos, merecem destaque o dicionário critico Les mots de lagéographie, dictionnaire critique, de 1993, e trabalhos publicados principalmente nas revistas L'Espace géographique (criada em 1972 por Roger Brunet) e Mappemonde, que a partir de 2004 passou a ser uma revista eletrônica chamada M@ppemonde. Para dar suporte técnico, foi criada a Maison de la Géographie, e com o apoio das comunidades locais, esse centro foi instalado na cidade de Montpellier, no sul da França, e representou um esforço para a descentralização do progresso científico e técnico.

Essa iniciativa está amparada nas soluções técnicas da época. Com o surgimento dos microcomputadores, foi possivel desenvolver estudos nas áreas de estatística e cartografia, auxiliando os trabalhos. O grupo contava com uma política editorial que deu visibilidade aos trabalhos que logo ganharam notoriedade e obtiveram diversos acordos com ministérios, autoridades locais, associações e empresas. Foi possível trabalhar junto às universidades com a formação de diversos estudantes. O grupo também entrou em acordos internacionais e pesquisas na União Europeia. 
Em função de um novo quadro político na França, em 1997 o GIP RECLUS é fechado, e sua liquidação legal é completada em 1999, tendo seus bens e direitos concedidos para outras instituições de pesquisa. Sua contribuição é enorme, seja pelo volume de material de pesquisa publicado, ou as novidades e avanços dentro do saber geográfico.Suas ideias estão presentes em vários trabalhos até os dias de hoje. Tendo como principais meios de divulgação duas revistas eletrônicas ${ }^{1}$, a francesa M@appemonde, dirigida atualmente por Denis Eckert e a franco-brasileira Confins, dirigida por Hervé Théry.

O primeiro resultado que procura sistematizar as ideias em volta da avaliação de território é apresentado por Roger Brunet nos anos de 1990 na Conférences sur la géographie sob o título de Évaluation et prospective des territoire (ECKERT, 1996), e publicado no mesmo ano em trabalho ${ }^{2}$ do GIP RECLUS sob o título de Evaluation des territoires et cartomatique (BRUNET, 1990). O autor reconhece a participação dos pesquisadores do grupo RECLUS na elaboração das ideias que permeiam o trabalho. Em 1996, o geógrafo Denis Eckert publica o livro Évaluation prospective des territoires, resultado de sua tese defendida em 1992 na Universidade Paris-I Sorbone sob o título de Evaluation prospective des territoires. Méthodes et concepts appliqués à l'Europe occidentale. Esse trabalho é responsável por avançar no tema e se aprofundar em questões ainda não trabalhadas por Brunet. O livro de Eckert apresenta as definições, o conteúdo da avaliação, preocupações, indicações, muito próximas das apresentadas por Brunet, mas avança no debate teórico, na proposição de uma abordagem, considerando o que chama de «sistemas territoriais». Por fim apresenta uma série de exemplos. $\mathrm{O}$ autor cita o trabalho que desenvolveu e aqueles que pôde acompanhar no GIP RECLUS como basilares na construção do arcabouço teórico e metodológico em volta da avaliação de territórios, ou avaliação prospectiva de territórios. Veremos a seguir que sempre que falamos em avaliação de território está implícita a ideia de prospectiva.

De uma maneira geral, avaliação pode ser definida como procedimento que julga ou calcula a qualidade, importância, quantidade, intensidade ou valor de alguma coisa. A avaliação envolve não somente variáveis objetivas, mas também variáveis subjetivas, como

\footnotetext{
${ }^{1} M @$ ppemonde, disponível em: <http://mappemonde.mgm.fr/>; e Confins, disponível em: <http://confins.revues.org/>.

2 BRUNET, R. Evaluation des territoires et cartomatique. In: BRUNET, R. (dir.), THÉRY,H.; PHILIPPE, W (coord.). Réseau cartomatique des départements et territoires d'outre-merpour l'information et l'aide à ladécision: rapport à M. le Ministre des Départements et Territoires d'Outre-Mer. Montpellier, Maison de la Géographie, 1990, 76 p. Disponível em: <http://horizon.documentation.ird.fr/exl-doc/pleins_textes/divers0801/010010797>.
} 
expectativas futuras, incitando a uma análise de desempenho. "A avaliação precisa da valoração. Mas a avaliação não é valoração". "Lugares e territórios são demasiado complexos para que possamos colocar um valor em uma escala, até mesmo pela combinação dos resultados de análises, mais ou menos ponderada" (BRUNET, 1990, p. 10). É preciso medir tudo o que se pode medir para especificar o que queremos. Logo, o uso de indicadores não só é importante como é recomendado, mas uma vez que os mesmos façam sentido e estejam dentro do contexto estudado, podem identificar os sistemas locais e determinar seus desempenhos. Como nos diz Brunet (1990, p. 10), "tudo o que pode ser medido é bom para avaliação, mas a avaliação não pode ser limitada àquilo que pode ser medido”.

Avaliamos algo ou alguém, e fazemos isso o tempo todo. Perguntamo-nos se isso ou aquilo é bom ou ruim, se esse ou aquele funciona melhor ou pior. Comparamos e comparamos sempre. Procuramos referências de qualidade em tudo, a ponto de dizer que isso é pior que aquilo. Buscamos critérios e parâmetros para nossas avaliações. Muitos campos do saber fazem uso da avaliação. Avaliação do ensino-aprendizagem, avaliação econômica do cenário internacional, da macroeconomia, da microeconomia, etc., avaliação da situação política ou geopolítica, avaliação sociológica, entre outras. O geógrafo faz avaliação geográfica sobre os lugares, sobre o espaço geográfico, sobre os territórios. Quando olhamos para eles o que perguntamos?

... o que podemos, que devemos pensar nesse lugar, nesse espaço? Como ele está, quais são seus pontos fortes, suas limitações, sua experiência ${ }^{4}$, suas tensões, seus riscos, suas conexões e sua dinâmica? Quais os principais problemas e perspectivas futuras. O que podemos fazer, o que pode ser feito? (BRUNET, 1990, p. 7).

Um dos objetivos da avaliação de território é a criação de um diagnóstico e seu objetivo final é a formulação de um julgamento. Isso se dá por meio da busca das melhores maneiras de avaliar as transformações contemporâneas, as dinâmicas recentes dos territórios. Com foco em procurar pistas de uma razoável e previsível evolução da situação atual, para assim poder identificar as condições sob as quais ela se transformou. A avaliação deve se

\footnotetext{
${ }^{3} L$ 'évaluation a besoin de valuation. Mais l'évaluation n'est pas la valuation (BRUNET, 1990, p. 10).

${ }^{4}$ Savoir-faire (em inglês Know-how), traduzido literalmente significa "saber fazer". É um conhecimento ou uma capacidade desenvolvida para executar alguma tarefa; logo, aquele indivíduo, grupo ou organização tem conhecimento de causa e experiência em determinada tarefa.
} 
voltar a um diagnóstico global, que possa medir a qualidade de um território (ECKERT, 1996).

Algumas ideias de Brunet (1990): o autor discorda de alguns pesquisadores quando falam que não há avaliação em si, mas apenas uma avaliação em relação a um objetivo previamente definido. Acrescenta que uma resposta deve ser abrangente, global, necessita levar em conta a integração com o entorno; deve ser complexa, não pode basear-se em dados isolados de um contexto, tendo sempre em consideração as características do local, as qualidades do ambiente e movimento ao longo do tempo. É possível concluir em poucas frases e imagens fortes uma avaliação, com respostas simples no lugar de trabalhos, possivelmente, muito pesados ou extensos; o geógrafo pode apreciar um lugar, um território em sua totalidade de uma forma global, melhor do que em um estudo específico de um determinado problema social.

Outra preocupação, quando se pretende fazer uma avaliação de território considerada por Brunet (1990), é o não comprometimento dos resultados com o juízo de valor do pesquisador. Ainda que reconheça a verdade em se ter juízo de valor sobre determinado espaço, por exemplo: a cidade dinâmica, um lugar violento, sem vida, etc., deve ser evitado. Pode-se apontar com objetividade as características de um lugar, comentar sobre o desempenho de determinado território, considerando que este pode funcionar bem para objetivos específicos que podem representar valores éticos detestáveis, mas o que não impede este de funcionar e de se reproduzir. Ainda assim, Brunet considera que devemos analisar risco, dano e destruição potencial de nosso objeto de estudo. Um exemplo é a qualidade do ambiente natural, seus efeitos adversos, ainda que o sistema se mantenha e até se expanda. Isso faz parte da avaliação, os desastres reais ou potenciais, ambientais ou de outra essência, não podendo ser negligenciados.

Uma vez feitas às primeiras considerações de forma geral sobre avaliação, Brunet passa a apresentar os conteúdos de uma avaliação prospectiva do território. Começa afirmando não haver um "modelo" de avaliação, e que nunca é bom trabalhar atrás de uma grade. A prática fez com que desenvolvesse um tipo de protocolo de trabalho, e que ainda assim esse deve ser adaptado para cada situação. Definiu cinco estágios:

\section{1 - Avaliação da situação geográfica}

Trata-se do estudo, um exame cuidadoso dos grandes campos espaciais. Esses campos correspondem não só à distribuição dos fenômenos no espaço, mas a uma organização dessa 
distribuição. Podem ser representados como: frentes, gradientes, rupturas, conquistas, margens, flutuações. E podem ser de ordem cultural e social, com fortes dimensões históricas (estruturas familiares, estrutura fundiária, comportamento demográfico, atitudes políticas, etc.), de ordem física (em especial bioclimática), de ordem econômica e técnica (fluxos turísticos, situação em relação a grandes cidades, redes de cidades, vias principais de transporte, etc.). "Os campos são de natureza essencialmente relacional: um lugar está "localizado", e mais ou menos "exposto" em relação aos grandes fluxos de comércio, migrações, invasões..." (BRUNET, 1990, p. 11). Em função dessa característica, toda avaliação territorial deve considerar que a análise nunca se limitará ao perímetro da área. A observação e a reflexão devem ser realizadas utilizando diversas escalas. "A avaliação deve, portanto, ser tomada como uma noção trans-escalas: o que torna impossível confiná-la no âmbito da análise regional" (ECKERT, 1996, p. 19). Em destaque, temos aqui o uso de mapas e modelos cartográficos como instrumentos para se conseguir identificar em meio às contingências locais as estruturas fortes do espaço.

\section{2 - Medindo a posição estatística}

Sabemos que para avaliar é necessário um conjunto de medições, um conjunto de dados e informações. Essa importância se dá quando se faz uma comparação, se tem de situar o território avaliado em relação a um espaço de referência, para apreciar melhor sua singularidade. Isso pode ser feito também por meio da comparação de espaços-irmãos, para aqueles que se assemelham e estão em situação semelhantes. Contudo, cabe uma avaliação

das estatísticas disponíveis. É de conhecimento que existem inúmeros indicadores. A dificuldade está em definir quais são mais pertinentes ao estudo e quais podem ser comparados, tendo em vista sua inadequação, principalmente quando têm origens distintas, de países, regiões ou instituições diferentes. Cabe aqui o esforço do pesquisador em escolher os indicadores mais "relevantes" em meio a tantos, indicadores que atraiam a atenção para fatos desconhecidos ou obscurecidos.

\section{3 - (Re) Construção do sistema}

Após possuir uma série de informações por meio de mapas, modelos espaciais e quadros estatísticos bem estudados, para uma avaliação não ser considerada superficial, ela deve contar com uma "representação dos sistemas que operam no espaço determinado" (BRUNET, 1990, p. 12). É necessário identificar os processos e atores que atuam naquele espaço, entender as conexões entre eles. É possível apresentar a interpretação do sistema por 
meio de um texto ou de uma representação gráfica. Como não se excluem mutuamente, podemos fazer ambos. Contudo, o segundo tem a vantagem de levar a melhor análise das ligações, das contradições, domínios, convergências e o que está ligado ao sistema. Podemos descrever as estratégias dos tomadores de decisões, porém, isso só é possível por meio de novas informações, que não estão nos quadros estatísticos.

\section{4 - A avaliação de desempenho}

Sobre a avaliação de desempenho de um território, devemos olhar para as diferenciações internas. Isso implica uma reflexão sobre a lógica interna, de como os componentes se relacionam, modos de regulação, risco de mau funcionamento, a expansão ou integração com outros espaços. Em outra escala, é importante a avaliação em comparação com espaços-irmãos e de que forma eles resolvem ou não os problemas semelhantes. E temos que levar em conta os grandes projetos, mesmo que "nem sempre seja certo que pese muito sobre o futuro" (BRUNET, 1990, p. 14). De outra forma, temos:

A ideia de um desempenho de um território, por mais estranho que possa parecer à primeira vista, é que se pode medir a atividade e destino dos chamados sistemas territoriais. Esse desempenho não tem, obviamente, nada a ver com uma nota ou um julgamento moral. A avaliação de desempenho deve ser construída em critérios objetivos, internos ao território (capacidade reprodutiva / armazenamento), ou externos (desempenho em comparação com objetos semelhantes). A avaliação de desempenho é essencial. Isto é o que nos permite considerar a avaliação de territórios como uma forma de julgamento e não como uma forma puramente discursiva. (ECKERT, 1996, p.18).

\section{5 - O diagnóstico}

Toda avaliação pressupõe um diagnóstico. Este deve ser encarado como positivo, deve apresentar as funções e disfunções, apontar para os riscos e oportunidades, revelar um conjunto de qualidades que alguns poderiam considerar como defeitos. "Além do diagnóstico, decisões e ações não são mais da responsabilidade da avaliação prospectiva". (BRUNET, 1990, p. 14). "A qualidade do diagnóstico depende das ferramentas da geografia em geral e do conhecimento local para avaliar" (ECKERT, 1996, p. 106). 


\section{Problemas de metodologia}

A avaliação deve ser realizada com rigor, uma boa revisão das fontes, das metodologias e todo o fundo teórico sobre a organização do espaço. O que é prospectivo são o "exame das tensões e os movimentos no sistema, o processo de acumulação, o significado e alcance das respostas a mudanças esperadas no ambiente, infraestrutura, estratégias" (BRUNET, 1990, p. 16). A prospecção é inseparável da avaliação, pois está intrínseca no processo de análise, quando se estuda a organização do espaço e se especula sobre as direções possíveis dos movimentos do sistema territorial. Caso isso aconteça, em termo espacial e temporal, é provável se ter tal efeito. Caso não se faça nada, é provável ir nessa direção. Em grande parte, a avaliação é uma questão de interpretação (BRUNET, 1990).

Como preocupações do avaliador, Eckert (1996) levanta as seguintes: compreender o funcionamento e criação de um território, ou seja, com quem, em contato com o que e quais são as alavancas que, postas em ação, poderiam alterar a estrutura das atividades exercidas ou o desempenho do sistema; a avaliação dos territórios deve ter como um dos objetivos a validade universal, não se pode restringir a validade neste ou naquele canto do mundo, ou este ou aquele tipo de espaço; o espaço geográfico é feito de práticas cotidianas de homens, indivíduos ou grupos. Logo, é necessário que o avaliador considere as lutas entre esses grupos de atores. No diagnóstico, deve-se observar o comportamento do sistema territorial, por meio de sua dinâmica procurar identificar sua capacidade em se reproduzir, de forma simples ou estendida, ou se ele segue em direção a uma transformação radical ou simplesmente desaparece. Isso facilitará a avaliar o desempenho do sistema, o que poderá indicar sua capacidade de sobreviver em sua estrutura ou, para preservar sua atividade, ter a necessidade de modificar sua estrutura, inovando afim de responder às perturbações do meio ambiente. "O objetivo é basicamente fazer suposições sobre o futuro desenvolvimento do território, tendo em conta fatores externos e internos: a avaliação do desempenho é fundamentalmente uma perspectiva" (ECKERT, 1996, p. 60).

O tempo é elemento fundamental na análise do espaço geográfico, considerando que os objetos geográficos estão suscetíveis as transformações constantes em sua estrutura e função. Essas mudanças são produzidas pelos grupos de atores que atuam no lugar e promovem alterações em elementos estruturais dos sistemas territoriais. Por isso, devemos examinar as ações e projetos dos atores, que são utilizados como alavancas na organização espacial. "As estruturas dos territórios não falam, contudo os atores locais são muito falantes" (ECKERT, 1996, p. 37). 
Denis Eckert (1996) argumenta que para que se possa realizar uma avaliação de território de maneira efetiva é necessário aceitar a hipótese suplementar da existência de sistemas territoriais, que são formados pelo arranjo da relação dos lugares e os atores do espaço, tomados em seu ambiente. Isso é explicável por uma totalidade que se organiza. É um conjunto num determinado espaço geográfico, tomado em sua maior extensão, onde se manifesta a sua atividade. É possível identificar os sistemas territoriais em diferentes níveis, bairro, cidade, região, clúster, megalópole. A questão está na capacidade do sistema em adotar uma organização para se diferenciar do seu entorno (meio ambiente). Sendo assim, não existe nenhuma escala a priori. Os sistemas territoriais podem estar sobrepostos. É importante não confundi-los com sistemas sociais ou econômicos, "embora este último, obviamente, contribui para qualificar os territórios" (ECKERT, 1996, p. 41), ou mesmo com sistemas cuja dimensão espacial é evidente, como as redes de transporte.

Os sistemas territoriais possuem elementos que podem ser chamados de processadores, que são responsáveis por contribuir na produção do espaço. Logo, o conjunto de processadores identificados e interligados forma a estrutura do sistema territorial. Sabendo disso, é possível reprogramar sua estrutura para determinado fim. Essa capacidade de conduzir alterações no layout dos processadores, ou inventar novas conexões, é exercida por um sistema de controle territorial. Todo o sistema territorial é gerido por um sistema de controle que regula o funcionamento do território e é formado por ações de seus principais interventores: grupos, indivíduos e instituições-chave. "O sistema territorial deve ser caracterizado pela capacidade de seus atores em definir e implementar projetos" (ECKERT, 1996, p. 51). O sistema de controle pode ser representado por seus projetos e decisões de seus “jogadores”, suas necessidades, prioridades, execução e alocação de recursos disponíveis, isto é, os fatores de produção, incluindo o próprio espaço (ECKERT, 1996).

Segundo Eckert (1996), ao final do processo, o avaliador deve ser capaz de responder às seguintes perguntas:

\section{O que se faz lá?}

Envolve medir a atividade do território, isto é, descrever a equação local da mobilização de recursos e de pessoal.

\section{O que é?}

Pensa-se aqui emsituar o território no seu ambiente mais próximo ou distante, tangível ou intangível. 


\section{O que vale a pena?}

Responder a esta pergunta é observar as qualidades do território: o que é proprio, o que ele sabe fazer melhor ou pior em relação aos outros, o que ele pode ou não pode fazer.

\section{Quem faz mover?}

O território é produto de uma atividade social e se deve identificar seus atores: quem (ou que grupos) é capaz de agir sobre as estruturas e o funcionamento do território.

\section{Com o que se faz mover?}

Procurar reconhecer as alavancas: pontos fracos ou fortes do sistema, os meios de transformação.

\section{Aonde vai?}

A questão-chave, de maior dificuldade, deve conduzir o fim do trabalho para uma declaração sobre o futuro do território: sua capacidade para se manter em suas principais características, a fim de melhorar seu próprio desempenho, para se transformar parcialmente ou completamente, ou mesmo para sua destruição.

De uma forma muito simples e direta, o autor consegue elencar as perguntas fundamentaisque uma avaliação de território procura responder. Tanto Eckert (1996) quanto Brunet (1990) dizem não ser produtivo amarrar a elaboração de tal avaliação por meio de uma grade rígida, ou seja, não devem existir receitas prontas e acabadas, que não abram espaço para novos saberes e novas práticas. Mesmo porque, na prática, o trabalho de avaliação de território é relativamente intuitivo. Ainda assim, é preciso se amparar em uma série de critérios bem definidos, afim de manter o rigor da análise. Isso começa com a definição das fontes, escolhas de indicadores, procedimentos metodológicos aplicados. Algo que é importanteno processo de avaliação é saber que sempre algo já foi dito sobre aquele objeto, e foi dito sobre diversas perspectivas. Eckert (1996, p. 108) fala em "herança científica" como forma de auxiliar a avaliação a chegar mais rapidamente nas questões nodais ou chave. É preciso fazer um levantamento das bases de informações e análises já elaboradas, os discursos que envolvem nosso objeto, as representações da área estudada. A avaliação e a finalização do trabalho dependem de disponibilidade de informações e que essas sejam de qualidade. 


\section{Coremática}

A coremática é apresentada pelo geógrafo francês Roger Brunet como teoria geográfica, que aponta para uma metodologia de análise da organização do espaço e que pode ser representado na forma de modelos gráficos. A primeira formulação é de 1980, em artigo publicado na revista L'Espace géographique, sob o título de La composition des modèles dans l'analyse spatiale (BRUNET, 1980), porém, a teoria coremática é resultado de um conjunto de pesquisas realizadas por Brunet apartir dos anos de 1960, "em relação com as possibilidades da teoria dos sistemas, o estruturalismo, a semiologia espacial, a cartografia e a modelização gráfica na geografia regional” (ÁLVAREZ, 1998, p. 7). Houve formulações posteriores (1986 e 1987) até chegar à obra que mais amplamente trabalha o tema, o volume introdutório da Géographie Universelle ${ }^{5}$, tendo uma versão publicada em 2001 como Le déchiffrement du Mond: Théorie et pratique de la géographie (THÉRY, 2004).

A palavra coremática vem de corema (chorème) $)^{6}$ que é "uma estrutura elementar do espaço, que se representa por um modelo gráfico" (BRUNET, 1986, p. 2). Se considerarmos que "O corema está para o espaço, assim como o fonema está para a linguagem, como uma estrutura elementar, que combinada, dá uma paisagem” (BRUNET, 2007, p. 59-60, apud DUTENKEFER, 2010, p. 104), temos a seguinte definição de coremática: "gramática dos coremas; ciência (ou arte) do tratamento dos coremas e da interpretação das estruturas espaciais pelo reconhecimento e pela composição dos coremas ${ }^{7}$ "(BRUNET et al., 1993, p. 105 apud PANIZZA, 2004, p. 56). “A coremática procede de uma preocupação pela investigação e comunicação científica, de um esforço racional fundado sobre a análise estrutural e sistêmica das formas espaciais criadas pela ação das sociedades" (BRUNET, 1996, p. 31). A coremática é, portanto, um procedimento teórico-metodológico de modelização gráfica e que faz uso dos coremas que são formas presentes no plano real que abstraímos e representamos na forma de modelos.

Essa teoria parte de algumas hipóteses. Que o espaço geográfico é um produto social estruturado, organizado e diferenciado em níveis de complexidade e que suas estruturas podem ser apreendidas conceitualmente e representadas graficamente segundo certas regras

\footnotetext{
5 BRUNET, R..Le déchiffrement du Monde. In: Géographie Universelle, t. 1, Mondes nouveaux.Paris/Montpellier, Hachette/GIP RECLUS, 1990, 554 p.

${ }^{6}$ Do radical grego Khoraou/Chora,que significa espaço ou receptáculo.

${ }^{7}$ Chorématique, grammaire dês chorèmes. Science (ou art) dutraitement des chorèmes et de l'interprétation dês structures spatiales par la reconnaissance et la composition des chorèmes (BRUNET, FERRAS, THÉRY, 1993, p. 105 apud PANIZZA, 2004, p 56)
} 
de modelização. Uma vez que as sociedades organizam e produzem seu próprio espaço, e se reproduzem através do mesmo, basta identificar os atores dessas ações. Brunet estabelece cinco tipos de atores: o indivíduo, os grupos, as empresas, as coletividades locais e o Estado. Esses atores têm quatro modos de produzir e de se apropriar do espaço: habitar, apropriar, explorar e trocar. E há uma quinta que seria o de gestão do território. Estas ações correspondem a quatro estruturas espaciais: maillage (malhas), conjunto de divisões territoriais definidas pelos sistemas de propriedade e gestão (estatal, público e privado); treillage ou quadrillage (grade, rede), rede de intercâmbio, circulação e comunicação; division spatiale du travail ou lieu de travail, divisão espacial do trabalho ou lugar de trabalho; e habitat, lugares de habitar, habitação (BRUNET, 1980, 1986, 2001) resumido na figura: Sistema de produção e dominação do espaço, que vem mais adiante.

$\mathrm{Na}$ medida em que as sociedades produzem espaço geográfico, para suprirem suas necessidades cotidianas, elas fazem seguindo lógicas sociais, resumidas em cinco formas de ação (habitar, apropriar, explorar, trocar e gerir). Como hipótese, o resultado dessas ações pode se traduzir por meio das configurações dos espaços, por campos, por lugares, por redes de complexidade variáveis (BRUNET, 2006) e que correspondem as estruturas espaciais que foram apresentadas acima (maillage, treillage, liuede travail e habitar). Para Brunet, o resultado das forças que agem sobre o espaço geográfico são formas especificas ou estruturas elementares que podem ser representadas por meio de figuras-chave, figuras fortes, figuras geográficas, os nomes variam, mas o sentido é o mesmo. Essas figuras representam aquilo que chamamos de coremas, que expressam as diferentes lógicas de controle e dominação do espaço, as quais Brunet distingue e classifica em sete: maillage e treillage ou quadrillage (malhas e grade $^{8}$ ) representam os meios diretos da dominação, depois, gravitation, contact, tropismo, dynamique territoriale e hiérarchi (gravitação, contato, tropismo, dinâmica territorial e hierarquia) refletem determinados efeitos das anteriores. Relacionando as sete lógicas apresentadas com as quatro figuras geométricas (ponto, linha, área e rede) temos os 28 coremas de base (BRUNET, 1986, 2001, 2006).Conforme figura: Coremas propostos por Brunet, que vem na sequência.

\footnotetext{
${ }^{8} \mathrm{Na}$ figura onde apresentamos os coremas propostos por Brunet, Eduardo P. Girardi (2008) traduziu quadrillage como disposição. Acreditamos que o fez desta forma para facilitar o entendimento ao relacionar com a quarta figura base que é a rede. Eduardo Dutenkefer (2010) traduz como ligação.
} 
Figura 1 - Sistema de produção e dominação do espaço

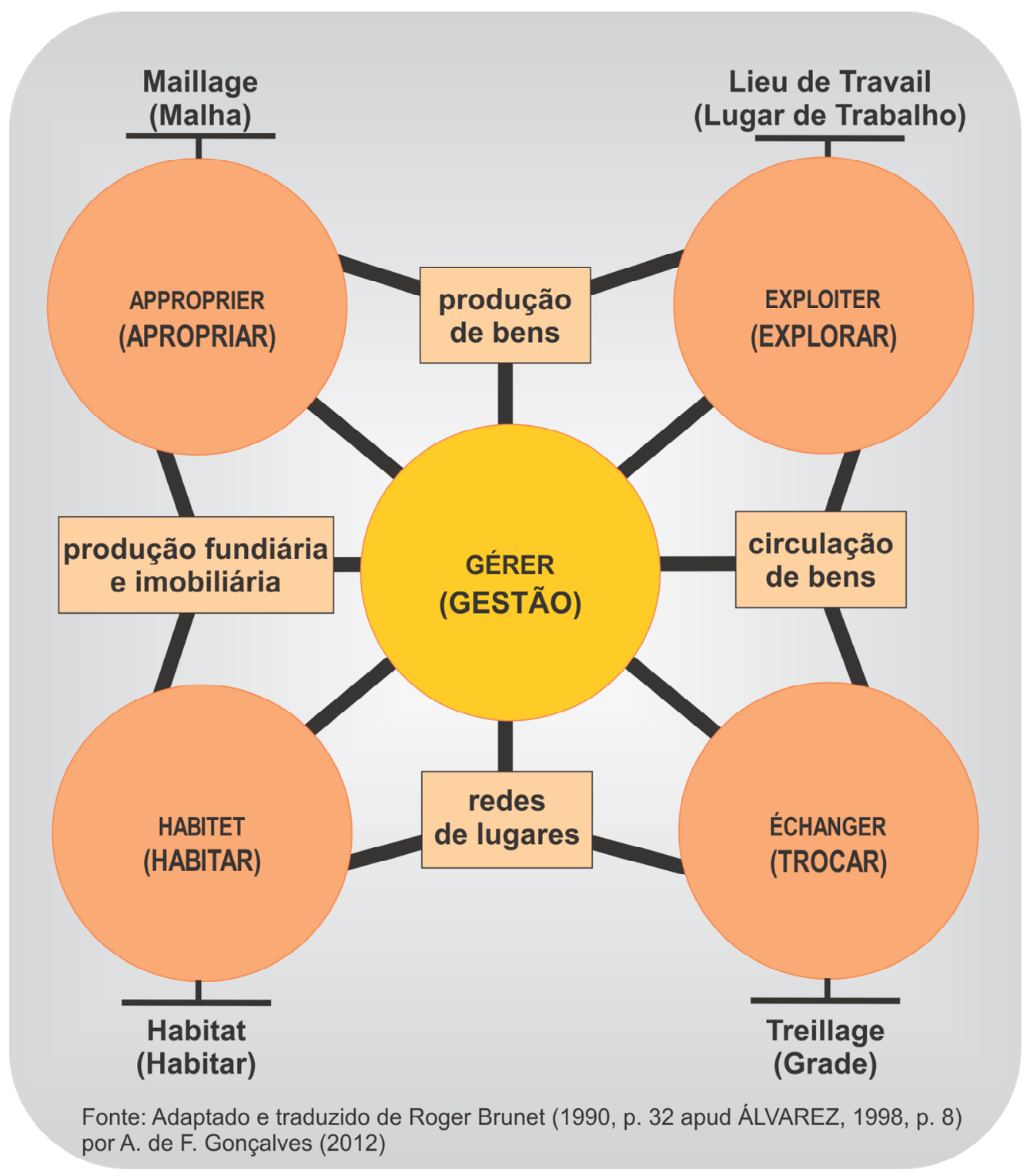

Fonte: Adaptado e traduzido de Roger Brunet (1990, p. 32 apud ÁLVAREZ, 1998, p. 8) por André de Freitas Gonçalves (2012)

A figura que apresenta os 28 coremas foi publicada inicialmente na revista Mappemonde em 1986, como a tabela das estruturas elementares do espaço ou a base (socle) da coremática. Brunet (1986) explicava dizendo ser uma tabela formada de quatro colunas de figuras básicas e sete linhas para representar as estratégias e dinâmicas essenciais, e destaca ser uma construção provisória. Que deve ser enriquecida, e que foi alimentada pela colaboração de um pequeno grupo da Maison de La Gégraphie ${ }^{9}$.

\footnotetext{
${ }^{9}$ Grupo formado por: F. Auriac, V. Cabos, C. Carrié. J.P. Cheylan, R. Ferras, J. P. Garnier, Th. Panouillères, M. Vigouroux, J.P. Volle.
} 
Quadro 1 - Coremas propostos por Brunet

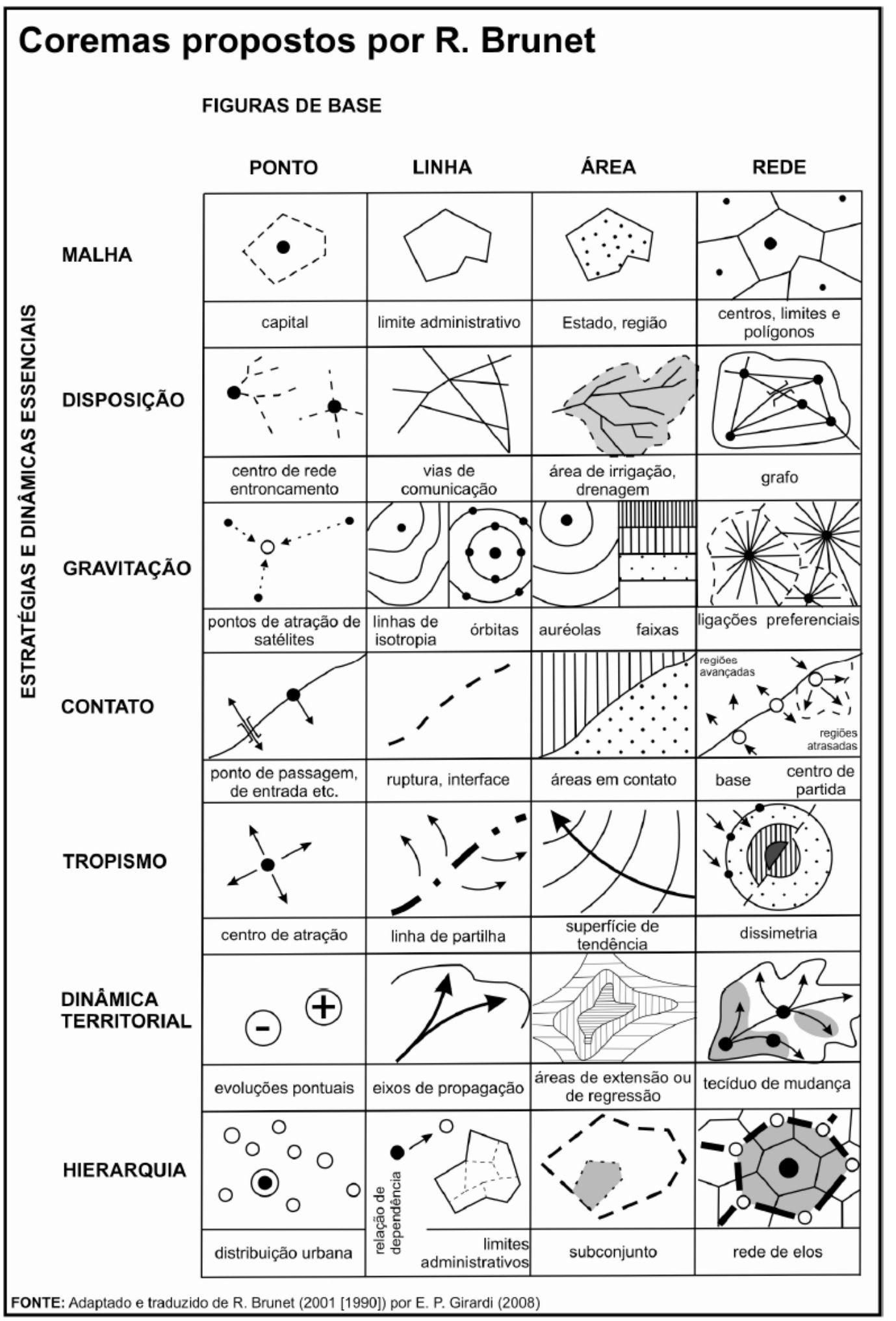

Fonte:Adaptado e traduzido de R. Brunet (2001) por E.P. Girardi (2008). 
Iremos utilizar o trabalho de tradução e discernimento das sete estratégias e dinâmicas essenciais, de Eduardo Dutenkefer (2010):

1. Maillage (Malha): se refere ao(s) sistema(s) de divisão e diferenciação do espaço. Maneira através da qual um território ou uma área é dividido, subdividido. Atributos do território com objetivos de apropriação, exploração e/ou administração;

2. Treilhage (Ligação ou disposição) (originalmente em BRUNET, 1986 era quadrillage (quadriculado): representa a configuração do território, a sua infraestrutura, o conjunto de redes de comunicação e circulação do espaço, assim como os fluxos que o suportam ${ }^{10}$;

3. Gravitation (Gravitação): No sentido de atração, influência, que afetam a distância. Este corema pode expressar, por exemplo, distribuição e organização espacial do tipo centro e periferia, hierarquias urbanas, centro(s) urbanos densos (de população, de equipamentos urbanos, empresas, etc.) ou rarefeitos. Também pode representar de modo aureolar, a partir do núcleo por meio de bandas;

4. Contact (Contato): representa dinâmicas de atração ou repulsão, interfaces (campo-cidade, por exemplo) ou também de rupturas (Terra-mar), descontinuidades;

5. Tropisme (Orientação ou tropismo): representa direções, orientações. Os fenômenos expressam a existência de orientações na organização do espaço de acordo com certas direções. São os gradientes, as dissimetrias, os fluxos dominantes em uma direção privilegiada;

6. Dynamique territoriale (Dinâmica territorial): representa os movimentos, fenômenos de expansão ou retração, de avanços ou retrocessos;

7. Hiérarchie (Hierarquia): representa ordem ou nível de estruturação do espaço e, portanto, em diferentes subordinações (exemplo, hierarquia das redes urbanas, funcionalidades).

A definição dos símbolos que servem para representar, em parte, é arbitraria, ainda que se utilizem algumas convenções da semiologia gráfica e se procure, no plano do real, similaridades com as formas gráficas produzidas. Como exemplo, o círculo é a expressão

${ }^{10}$ Alteramos aqui utilizando a referencia do texto de Álvarez (1998). 
elementar da gravitação e as formas aureolares são as órbitas (BRUNET, 1980). Este caso, que representa sobre uma figura, uma maneira de entender o funcionamento do espaço, mostra uma característica da teoria coremática que é a hipóteses fundamental das leis do espaço:

\begin{abstract}
A hipótese fundamental das leis do espaço é que essas se fundam sobre a gravitação. Tudo ocorre "como se". Como se em todo lugar no espaço geográfico exercesse sobre os outros uma atração em função direta de sua massa e em função inversa da distância que os separam; como se todo lugar experimentasse com relação aos outros uma atração em função direta de sua massa e em função inversa de sua distância; como se, entre dois lugares, a intensidade da interação espacial fosse função direta de sua massa (mais exatamente, do produto de suas massas) e função inversa de suas distâncias... (BRUNET 1990, p. 79 apud ÁLVAREZ, 1998, p. 8)
\end{abstract}

De uma forma sintética, HervéThéry apresenta as hipóteses básicas da teoria coremática em seu artigo Modelização gráfica para a análise regional: um método (2004):

- Será suficiente dizer que a hipótese básica é que cada lugar situa-se numa série de campos que estruturam o espaço, cuja interferência local forma um sistema; que cada situação define-se em relação a fluxos, por conseguinte em relação a centros, direções, limites. Definir-se-á, por exemplo, uma porção do espaço (usando uma metáfora da situação em relação aos ventos alísios) como "a barlavento" ou "a sotavento" da inovação, próxima ou remota da capital, ou do mercado, ou de centros de influência, etc. Ou lado do "certo" ou do "ruim" de uma ou de outra fronteira, deste ou daquele limite;

- Outra hipótese forte é que estas estruturas e as suas combinações podem ser representadas por modelos. Estes, como nas ciências "duras" são simplificados, redutores provisórios, constituindo uma abordagem simplificada da complexidade, um instrumento que pode ser utilizado provisoriamente, até se construir outro melhor. Os físicos sabem que um elétron não é uma pequena esfera que gravita ao 
redor do núcleo, como a Lua ao redor da Terra, mas eles se servem desta analogia enquanto lhes for útil, para abandoná-la depois;

- Postulamos, por último, que estes modelos podem ter uma expressão gráfica. A expressão gráfica tem sobre o discurso linear a superioridade de poder ser apreendida no espaço, e por conseguinte de ser mais bem adaptada para simbolizar a organização espacial, de ser mais sintética e ter neste domínio uma melhor eficácia demonstrativa. Essa premissa supõe, contudo, que tenhamos em conta as regras da semiologia gráfica, que produzamos "imagens a ver" e não "imagens a ler”, segundo a distinção de Jacques Bertin.

Apresentamos até aqui, uma série de conceituações e referências para que possamos compreender as bases da coremática a fim de compreender o processo de construção de um modelo gráfico. Em sua obra-prima em 1980, Brunet lista cinco regras para a "modelização das organizações espaciais":

1. Modelizar um espaço não se trata de resumir nem de generalizar, mas de "procurar suas estruturas e suas dinâmicas", ou seja, "limpar pouco a pouco as rugosidades até produzir uma figura geométrica";

2. Toda configuração espacial revela a combinação complexa de mecanismos simples, que "correspondem às soluções que as sociedades encontram para os problemas de domínio do espaço", como por exemplo, a apropriação, a gestão, a conquista; ou os problemas relacionados "às forças físicas", como escarpas e as declividades; ou ainda, as distâncias entre os lugares e as fricções em relação à circulação e à informação que podem variar entre a fluidez perfeita e a ruptura;

3. As configurações são entendidas pela combinação de algumas estruturas elementares, cujas formas são as bases de representações cartográficas, tais como: ponto, linha, polígono e rede. Cada corema possui um significado que representa o mecanismo atuante. Assim, "ele revela um processo, um arranjo. Por isso, a modelização é um poderoso instrumento de pesquisa e comunicação ao mesmo tempo"; 
4. O ato da modelização gráfica não é nem gratuito nem arbitrário, deve haver discernimento no reconhecimento das formas, pois essas representam realidades sociais;

5. A modelização gráfica se aplica a todas as escalas, de um vilarejo às zonas climáticas do globo. Aplica-se igualmente na análise da distribuição de um fenômeno, na análise de uma organização particular (uma cidade, uma região, etc.) ou na comparação de organizações de mesma natureza, como por exemplo, as metrópoles ou os deltas (BRUNET, 1986, p. 2-4, apud PANIZZA, 2004, p. 75-76).

Encontrar maneiras melhores de apresentar e representar a organização do espaço geográfico é, sem duvida, uma tarefa árdua. A coremática ou modelização gráfica está entre essas maneiras. Para além das críticas e divergências teóricas muito bem apresentadas por Álvarez (1998) e Panizza (2004), a coremática associada aos instrumentos de cartografia ou simplesmente ao mapa, "constitui a etapa mais avançada da análise espacial por meio do mapa, pois, embora o resultado do exercício não seja um mapa, a elaboração dos modelos só é possível a partir do entendimento das estruturas verificadas em conjuntos de mapas anteriormente analisados pelo pesquisador" (GIRARDI, 2008, p. 77). Por meio de suas formulações sobre a modelização gráfica, Brunet consegue "deslocar do simples mapa de ilustração para levar o mapa em direção a uma síntese reflexiva" (BORD, 1997ª apud FONSECA, 2004, p. 17). 


\section{Cidade de São Paulo}

Compreender as transformações territoriais de uma grande cidade como São Paulo é um desafio em que pesa a capacidade de relacionar diferentes fatores, momentos e escalas geográficas, ou seja, identificar correlações entre os processos particulares ao lugar e os processos mais gerais. A importância desse pressuposto está na possibilidade de identificar os agentes transformadores do território. Não há dúvidas sobre a potência do período atual em transformar constantemente o meio construído, seja através da criação de novas formas ou na redefinição de seus conteúdos; nesse sentido, cabe ressaltar o papel condicionador das formas e estruturas materializadas no espaço geográfico diante dos novos impulsos de modernização, isto é, a importância dos arranjos e a configuração espacial que determinado território acumulou durante o tempo frente às novas formas de apropriação e produção do espaço.

Para que possamos compreender a dinâmica territorial da cidade, devemos compreender os processos gerais que atingem direta ou indiretamente, que afetam pouco ou muito. Os impactos de modernizações seletivas produzidas pela globalização é um começo.

Neste trabalho, é importante definir a globalização como resultado principal de dois processos, a saber: a constituição de um novo sistema técnico com a presença potencialmente planetária; e a criação de um mercado global (SANTOS, 2000). A principal característica desse novo sistema técnico é a chamada técnica da informação, que por meio da cibernética, da informática e da eletrônica, possibilitou que a informação fluísse instantaneamente, permitindo a comunicabilidade entre as diferentes técnicas, sua integração e a simultaneidade das ações, acelerando o processo histórico e assim possibilitando o processo atual da globalização (SANTOS, 2000 e 2004).

O processo de globalização que se dá na escala mundial não é homogêneo quando nos referimos à maneira com que se manifesta no território. A constituição de um mercado global, em particular por meio do novo sistema técnico, bem como a reestruturação produtiva, fizeram com que se acentuasse a divisão territorial do trabalho, tendo como resultado a seleção e especialização dos lugares que são escolhidos por meio de estratégias espaciais e locacionais a serviço da acumulação capitalista (SOJA, 1993), provocando, assim, desigualdades geográficas para certos fins sociais determinados (SMITH, 1988), acentuando as desigualdades entre as pessoas dentro do mesmo território (BRUNET, 2006).

É importante identificar na configuração territorial da cidade os subespaços especializados, construídos por meio da ciência e da técnica com a finalidade de tornar as 
ações, realizadas nesses lugares, mais eficientes. Contudo, essa eficiência é possível, sobretudo, em função da crescente fluidez do território que, no período atual, é alcançada principalmente pelo desenvolvimento da técnica da informação, utilizada na criação de sistemas informacionais que, direta ou indiretamente, rege todos os fluxos. Estes são alimentados pelas inovações técnicas que abrem a cada dia novas possibilidades de circulação ainda mais rápida e eficaz; entretanto, a constituição dessa fluidez não é uma categoria técnica, mas sim sociotécnica, em outros termos, a fluidez "não alcançaria as consequências atuais se, ao lado das inovações técnicas, não estivessem operando novas normas" (SANTOS, 2004, p. 275). Portanto, há também um processo de “desregulamentação"/nova regulamentação, configurando um novo sistema de normas capazes de gerenciar as redes e os fluxos. O processo de gestão dos territórios está em constante transformação, adaptando-se às novas exigências.

O resultado da criação desses subespaços especializados é a fragmentação territorial da cidade, que vai permitir a eficácia de uma determinada função geoeconômica, que é definida e está a serviço dos interesses hegemônicos, conformando o que se pode denominar de espaços da globalização (SANTOS, 2000 e 2004; SOUZA, 2004; SILVA, 2005).

Com a complexidade dos processos e a variedade de atores que agem sobre os territórios, nossa tarefa de trabalhar em várias escalasse tornou ainda mais complicada, exigindo uma compreensão melhor do mundo como um sistema, onde tudo está conectado. Ao mesmo tempo, é interessante trabalhar com o local, porque os processos mais gerais resultam no aumento das diferenças sociais e geográficas nos lugares, principalmente nas cidades. É nessa escala que encontramos as autoridades locais, regiões, províncias e cidades que se tornaram mais importantes no planejamento, desenvolvimento e reestruturação dos territórios (BRUNET, 2006).

Com o aporte teórico indispensável para analisar uma cidade como São Paulo, aplicaremos a metodologia de avaliação de territórios, com os seguintes conteúdos: dinâmicas históricas e demográficas, a fim de desvendar a gênese do território; em seguida, as dinâmicas produtivas, dinâmicas urbanas, redes e fluxos, onde analisaremos a questão de infraestrutura e mobilidade urbana; e, por fim, a síntese com apresentação de um modelo gráfico, no qual faremos uso da coremática - ou modelização gráfica - para apreender a dinâmica territorial e organização do espaço geográfico da cidade, tendo em vista compreender as transformações que se sucederam como também apresentando uma síntese dos processos em curso. 


\section{Dinâmicas históricas e demográficas}

Toda a produção do espaço deixa marcas que, em períodos futuros, podem representar um beneficio para determinada função, ou até mesmo um malefício. Por exemplo, toda a densidade técnica adquirida e acumulada pela área central de uma grande cidade pode ser utilizada plenamente ou subutilizada. Isso vai depender das ações aplicadas a esses objetos técnicos, a refuncionalização de antigos objetos e a criação de novos, a fim de integrar as possibilidades de uso. Afinal:

(...) a organização do espaço é também uma forma, um resultado objetivo de uma multiplicidade de variáveis atuando através da história, sua inércia passa a ser dinâmica. Por inércia dinâmica entendemos que a forma é tanto resultado como condição do processo. As formas espaciais não são passivas, mas ativas; as estruturas espaciais são ativas e não passivas, mesmo que sua autonomia, com relação a outras estruturas sociais, seja relativa. Mas as formas espaciais também obrigam as outras estruturas sociais a modificar-se, procurando uma adaptação, sempre que não possam criar novas formas. (SANTOS, 2008, p. 45)

A dinâmica demográfica de uma cidade se relaciona diretamente com as condições, materiais e imateriais, presentes em determinado período histórico de sua formação socioespacial. Essas condições podem ser: a produção de redes de transportes, associada à criação de normas de uso e ocupação do solo, o ato de infringir tais normas, os caminhos e rotas onde circulavam mercadorias e pessoas antes de sua formação, e a efetivação de um complexo entrelaçar de linhas sobre um nó.

As formas e estruturas do passado, bem como a constituição e organização do espaço urbano ao longo da história, nos deixam pistas que auxiliam na análise do hoje. $\mathrm{O}$ modo pelo qual o povoamento de uma cidade aconteceu, associado à sua dinâmica de crescimento demográfico e de produção do espaço urbano, é de fundamental importância para compreensão do presente. Portanto, faremos uma breve análise de como foi a gênese do território paulistano, com a formação de suas redes de circulação e dinâmica demográfica. 


\section{Circulação, gênese do território e dinâmica demográfica}

Hoje em dia, a circulação de pessoas, mercadorias, informação e dinheiro se realiza de diferentes formas, porém com um objetivo em comum: a redução do tempo na transferência de tais elementos de um ponto ao outro. Esse objetivo não é exclusivo do período contemporâneo, pois sempre esteve presente na história da organização social, como podemos observar na criação de montarias, caminhos, estradas, barcos, navios, correios, telégrafos, aeronaves, até as tecnologias mais avançadas da atualidade. O que torna determinante para produzir um território cada vez mais fluido, com redes que o fazem mais e mais eficiente e veloz, são as exigências impostas para o desenvolvimento do sistema capitalista.

Criam-se objetos e lugares destinados a favorecer a fluidez: oleodutos, gasodutos, canais, autopistas, aeroportos, teleportos. Constroem-se edifícios telemáticos, bairros inteligentes, tecnopolos. Esses objetos transmitem valor às atividades que deles se utilizam. Nesse caso, podemos dizer que eles "circulam". É como se, também, fossem fluxos (SANTOS, 2004, p. 274).

Por meio da construção dessas estruturas, procura-se tornar o processo de circulação eficiente, com vários desígnios, mas, sobretudo, "a redução dos custos da circulação real (no espaço) faz parte do desenvolvimento das forças de produção pelo capital" (MARX, 1973, p. 533-4. In: HARVEY, 2001, p. 49). A redução dos custos de transporte afeta diretamente os preços de matérias-primas ou bens acabados.

Quando pensamos nas cidades, e de que forma seus territórios foram e são produzidos, devemos considerar um elemento essencial nesta produção que são as redes. São elas que possibilitaram a comunicação entre as diversas cidades. Por exemplo, uma rede urbana hierarquizada foi fundamental para o crescimento populacional da cidade de São Paulo, que se utilizou da sua condição geográfica como ponto de conexão com o porto de Santos para se beneficiar dos fluxos que alimentavam esse caminho. 
Atualmente, essa forma hierarquizada de rede urbana não existe mais. Mesmo que uma rede e seus fluxos integre as diversas atividades e cidades, tornando-se uma articuladora de todo um território ${ }^{11}$, há desconexões das grandes cidades com seu entorno ${ }^{12}$. Uma cidade pode ter acesso a mercados externos sem necessariamente estar dependente da metrópole que polariza a rede urbana.

A densidade das redes tem relação com o crescimento econômico e populacional das cidades, o que ajuda a determinar a espessura do território. As rotas, os caminhos, os sistemas de transportes, as redes de fibra óptica, todas influenciam a capacidades de se produzir espaços compactos.

É por meio desse enfoque, onde as redes ganham preponderância na produção e organização dos territórios, que analisaremos a formação da cidade de São Paulo a partir de sua fundação. Isso é o nó primas do que viria a se tornar o ponto mais complexo do conjunto das redes no país.

\section{As redes precursoras de São Paulo}

Deixando o litoral, onde se encontram todas as grandes cidades do período da colonização, e superando os aproximadamente 800 metros de altura da Serra do Mar, encontramos no planalto um pequeno ponto de colonização portuguesa que viria a se tornar o maior aglomerado urbano do hemisfério sul.

As causas que determinaram a grandeza de São Paulo vêm atuando desde o início da colonização; e numa persistência digna de nota, se mantiveram até hoje apesar de todas as transformações econômicas, sociais e políticas por que atravessou nosso país nesses 400 anos de sua existência. (PRADO JUNIOR, 1936, p. 7)

\footnotetext{
${ }^{11}$ Em artigo intitulado Dinâmica socioespacial e a rede urbana paulista (1995), Aurílio Sérgio Costa Caiado mostra a importância da rede urbana nos estudos sobre distribuição das atividades econômicas e a dinâmica populacional.

12 G. Benko (2002) indica que essa desconexão estaria acontecendo nas grandes cidades mundiais, tomando como referência Paris, e questiona onde ficaria a questão da solidariedade territorial dos que estão fora das áreas dinâmicas.
} 
As causas de que falava Caio Prado Junior (1935) são de ordem físico-territorial, como exemplo as condições climáticas favoráveis do planalto em relação às do litoral frente ao colonizador europeu e a possibilidade de desenvolvimento de uma agricultura; encontramos também condições favoráveis em termos de acesso. Uma vez que o interior deveria ser colonizado, onde mais seria possível alcançá-lo com facilidade, tendo uma serra que se estende praticamente por todo o litoral da província, senão por meio do caminho que os próprios indígenas faziam para subir a serra e acessar o interior? Na região de Santos, onde a serra tem altura de cerca de 800 metros, logo em seguida ao abrupto, já temos um terreno plano de fácil percurso que nos leva ao ponto inicial da futura cidade de São Paulo dos Campos de Piratininga, condição essa muito mais favorável ao que se tinha no litoral norte ou sul do estado. Um olhar atento ao percurso da linha férrea no planalto, desde a estação mais perto da serra até a mais próxima da cidade de São Paulo, não verificamos nenhuma grande obra e nenhum túnel, "tais são os motivos que fazem dessa passagem, já muito antes da vinda dos portugueses, um caminho predileto dos índios" (PRADO JUNIOR, 1935, p. 17).

Importante destacar que desde o início, a conquista do planalto esteve sempre como objetivo dos colonizadores que vinham atrás de riquezas, estas que não se encontravam no litoral. Portanto, houve um deslocamento do centro da colonização paulista, do litoral para o planalto. Esse é um fator de suma importância, responsável pela constituição e desenvolvimento do núcleo da capitania e de todo o sul da colônia de São Paulo (PRADO JUNIOR, 1935).

Uma vez consolidado como ponto de partida para a colonização do interior ${ }^{13}$, São Paulo tem mais um ponto a seu favor em termos de sua situação geográfica, localizando-se no centro do sistema hidrológico da região. Por meio dos rios próximos, e até mesmo do rio Tamanduateí que margeia o núcleo fundador de São Paulo, é possível ter acesso ao interior nas mais diferentes direções. (PRADO JUNIOR, 1935). Tendo o rio Tietê como grande tronco central de comunicação que se articula com dezenas de outros, pôde-se alcançar o Mato Grosso, terra que despertava interesse em função do ouro como veremos a seguir.

O sistema hidrográfico é o primeiro conjunto de rede de comunicação de que São Paulo fará uso e, por ser seu principal nó, se desenvolverá a partir da intensificação dos fluxos. Esse sistema começará a ganhar cada vez mais importância, fazendo com que a rede

\footnotetext{
${ }^{13}$ Não entraremos aqui nos pormenores de como a São Paulo dos jesuítas teve ganho de causa em suas pretensões de se tornar a principal vila do planalto frente à Vila de Santo André de João Ramalho e os mamelucos. Ver a respeito em: Baptista Pereira. A cidade de Anchieta, maio de 1936. In: Revista do Arquivo Municipal, São Paulo, 2004, vol. 202, p.1-176.
} 
ganhe cada vez mais nós e fique mais complexa. Em outros termos, isso significa dizer que, ao longo dos rios, vão se criando polos de povoamento e novas vilas.

"Partindo de São Paulo o povoamento do planalto começa por seguir duas direções, ambas pelo Tietê: um rio a cima, outra rio a baixo. É seguindo estas linhas que os colonos se vão estabelecendo e formando as primeiras povoações e vilas" (PRADO JUNIOR, 1935, p. 21). Rio a cima teremos o surgimento desde muito cedo da Nossa Senhora da Espectação do Ó (hoje Freguesia do Ó) e Parnaíba; pela variante do Rio Pinheiros, teremos Cotia e M’Boi-Mirim, e aldeias de índios fundadas ou dirigidas pelos jesuítas como Pinheiros, M'boi, Itapecerica e Ibirapuera (hoje Santo Amaro); rio a baixo, teremos Guarulhos, Itaquaquecetuba, São Miguel e Vila de Mogi das Cruzes.

A exemplo do que aconteceu com essa rede de comunicação, que potencializou o surgimento de povoados e vilas ao longo dos rios, a rede de caminhos que apareceu logo em seguida também cresceu, ficando cada vez mais complexa. Veio a se integrar com o sistema anterior, tornando-se indutora de novos povoados e vilas. No mapa a seguir, podemos ver o traçado desses caminhos e como eles se encontram em São Paulo. Pode-se observar, também, o sistema hidrográfico do qual falamos.

Esses caminhos conectavam não somente regiões da capitania de São Paulo, mas também do país, caso do Sul com o Nordeste, o Centro-Oeste (Mato Grosso e Goiás) com o litoral. Enfim, tudo passava por São Paulo. Como exemplo, temos o "caminho das mulas", trajeto feito pelos comerciantes das tropas de burros, principal meio de transporte até então. Vindos pela estrada que passa pelos Campos de Sorocaba, Itapetininga e Guarapuava no Paraná, tais comerciantes levavam as mercadorias produzidas no sul do país para serem comercializadas em São Paulo. Ainda conforme o mapa, podemos verificar que o acesso ao Mato Grosso, que é de grande importância a partir do momento que se começa a lavrar o ouro, é realizado pelo rio Tietê. É com o aumento da frequência dessas viagens rio a baixo que surge o porto de Araritaguaba ${ }^{14}$, mais tarde chamado Porto Feliz, ponto de embarque para que se pudessem evitar as grandes cachoeiras.

\footnotetext{
${ }^{14}$ Termo em tupi que significa "lugar da pedra de arara", formado pela junção dos termos arara ("arara"), itá ("pedra") e aba ("lugar"). A partir de 1693, Os historiadores falam de um "Porto" à margem esquerda do Rio Tietê, de onde partiam as expedições para Cuiabá, no Mato Grosso; nessa data, também teve início o povoamento de Araritaguaba.
} 
Mapa 1 - Os principais caminhos em fins do século XVIII

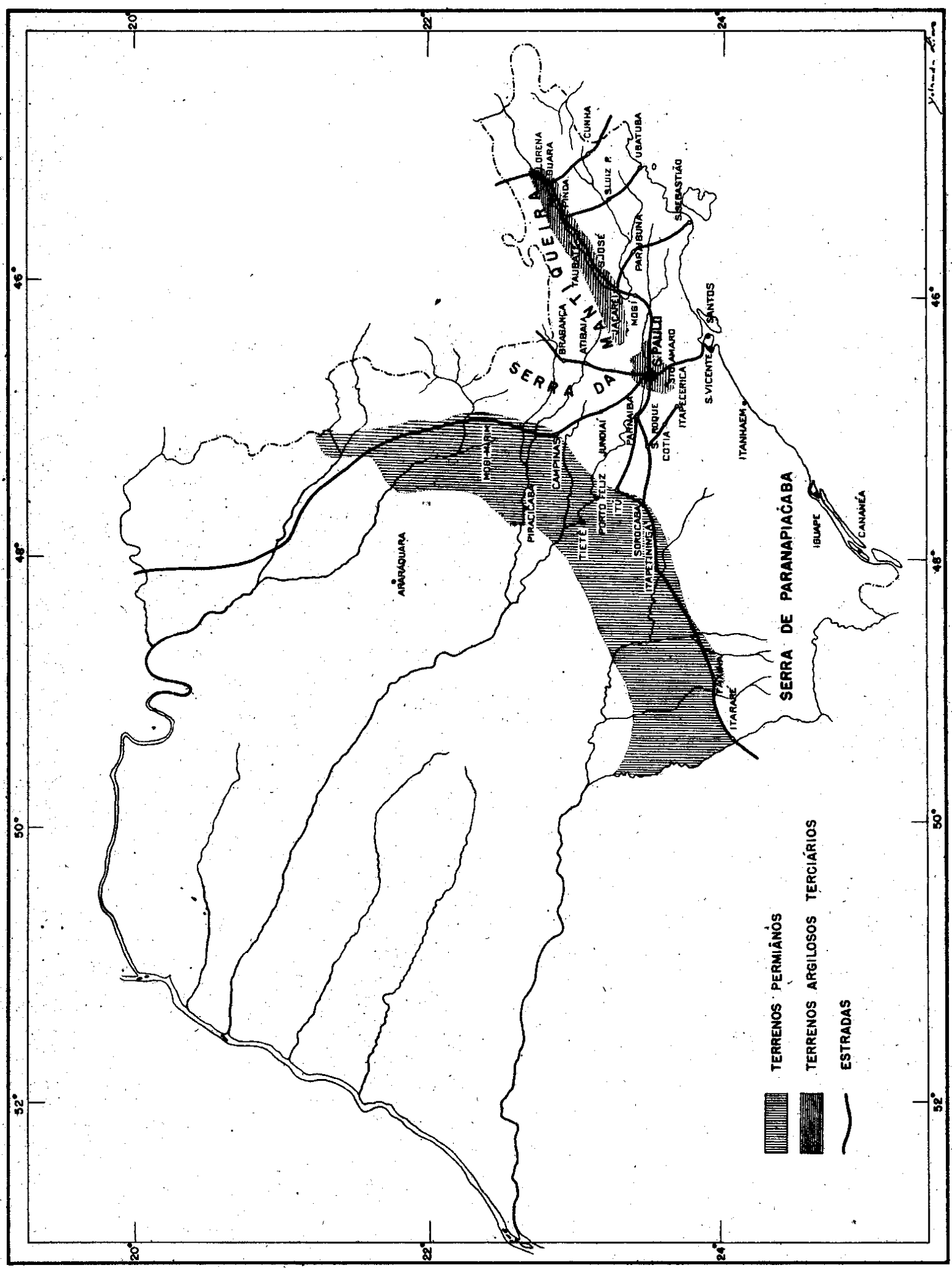

Fonte: Caio Prado Junior. O fator geográfico na formação e no desenvolvimento da cidade de São Paulo, 1935. Geografia, ano I, nº. 3, São Paulo, 1935. 
Até aqui, podemos perceber o papel que São Paulo teve na colonização e exploração de terras longínquas, estabelecendo vínculos com o Sul do país e até Cuiabá em Mato Grosso, mesmo antes da criação das ferrovias. Portanto, é mister reconhecer a importância das redes de comunicação anteriores às ferrovias, como o sistema hidrográfico e os caminhos, que foram indutores de povoamento e do desenvolvimento econômico de toda a província, mas sobretudo da cidade de São Paulo. Porém, São Paulo é o ponto intermediário da comunicação de um sistema que podemos chamar de "São Paulo - Caminho do Mar Santos".

Desde logo se estabelece entre estes dois núcleos, São Paulo e Santos, uma ação recíproca permanente e a importância de um se projeta fatalmente sobre o outro. Ambos se completam e no sistema cada qual tem uma destas funções conexas e inseparavelmente ligadas: centro natural do planalto e porto marítimo. Não fosse a fatalidade da Serra do Mar, estas duas funções caberiam a um só centro, que englobaria o que hoje constitui as duas cidades. A configuração geográfica do território apartou estas funções. O Caminho do Mar que as articula restabelecendo a unidade que necessariamente as deve englobar, tira daí toda sua considerável importância. E o sistema "São Paulo - Caminho do Mar - Santos" torna-se o eixo, a base do organismo econômico da capitania (Prado Junior, 1935, p. 23).

A figura seguinte exemplifica a configuração desse sistema, sua estrutura que chega a São Paulo com ramificações vindas de diferentes direções, conectando pontos de territórios afastados, e fazendo com que toda essa extensão se encontre em um só ponto e a partir dele alcance o litoral e, portanto, o porto de Santos. Essa representação do sistema de viação da capitania de São Paulo mostra a importância das redes em forjar novos territórios, como a criação de um acesso a um determinado local pode significar o seu desenvolvimento. Tal fenômeno mais ou menos vai depender da intensidade e qualidade dos fluxos que alimentam tal rede.

Esses caminhos, rotas, via de acesso e comunicação com outros lugares serão mais ou menos importantes em função do contexto histórico de determinada época. Para cada período histórico, existe um tipo de rede especifico que é preponderante no processo de 
desenvolvimento econômico-territorial de uma determinada localidade, mesmo que coexistam diferente tipos de redes. O fundamental, e o que normalmente acontece, é que elas se comuniquem.

\section{Figura 2 - Resultados atingidos pela colonização paulista em fins do século XVIII}

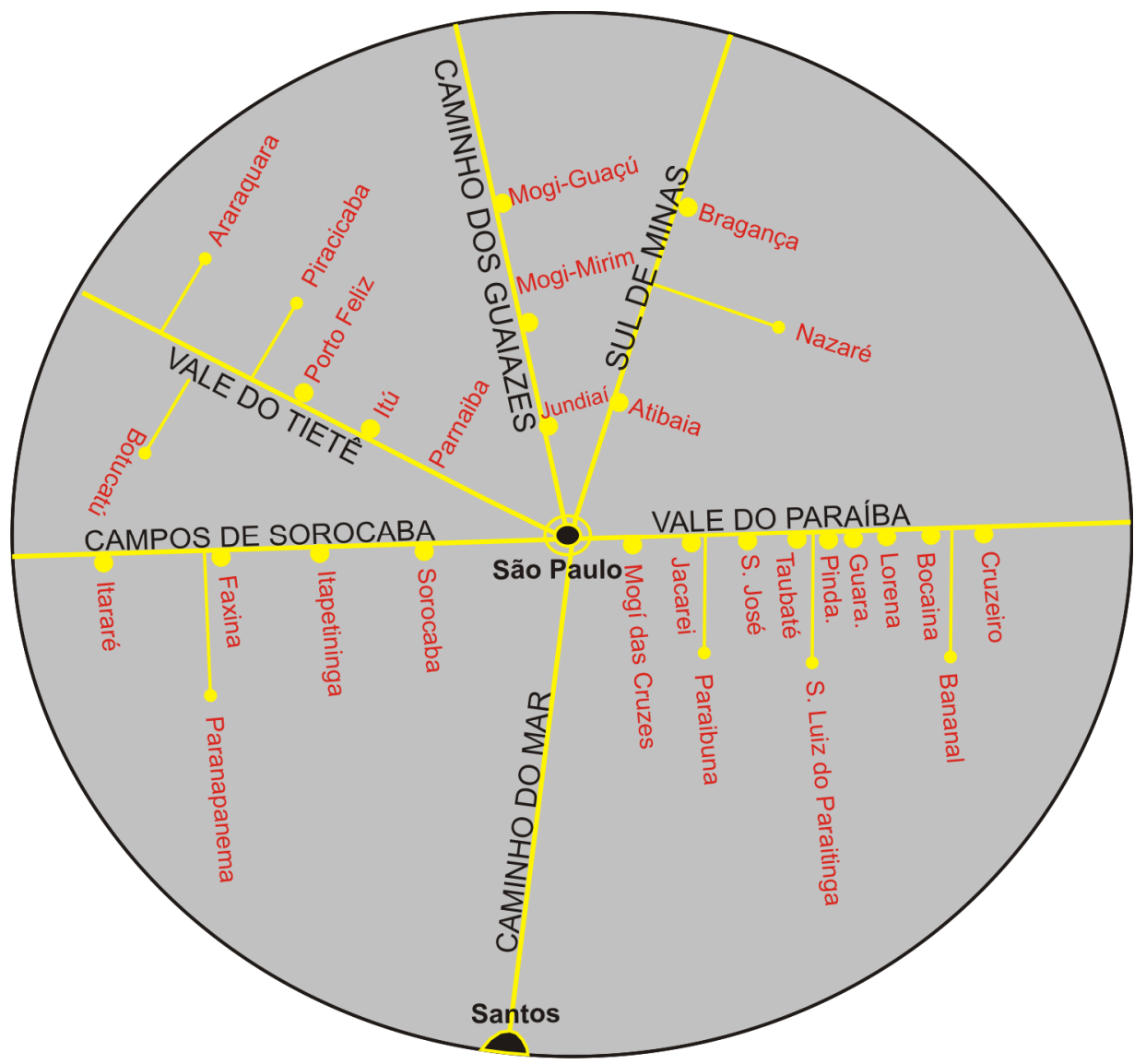

Fonte: Caio Prado Junior. O fator geográfico na formação e no desenvolvimento da cidade de São Paulo, 1935. Geografia, ano I, nº. 3, São Paulo, 1935.

Adaptação: André de Freitas Gonçalves

Antes mesmo da criação de ferrovias e rodovias, São Paulo do início do século XVIII se beneficiou da exploração do ouro em Minas Gerais, até a criação do "caminho novo" em 1725, que passava para o Rio de Janeiro todo o fluxo de mercadorias. Depois continuou sendo dominante o comércio da mineração em Mato Grosso e Goiás. Neste período, São Paulo era o principal entreposto comercial da província, ligando o planalto com o litoral, o interior com o "exterior" (SINGER, 1968). Esses caminhos tiveram importância para um certo desenvolvimento, possibilitando-lhe que fosse elevada à condição de cidade em 1711 e sede do bispado em 1745. 
Em função da capacidade de exercer o papel de entreposto para o período descrito, é que São Paulo consegue se beneficiar do comércio de mulas na feira de Sorocaba, que era o destino desses animais criados no sul do país. Passavam por São Paulo as mulas para serem usadas ou exportadas. Outra fonte de recursos era proveniente das "monções" da região aurífera de Mato Grosso que escoava a produção por via fluvial até Porto Feliz e depois seguia por terra até São Paulo.

Esses caminhos e rotas tinham São Paulo como ponto de referência, um verdadeiro nó que só aumentava sua importância e polaridade. Fazendo com que a população da cidade ganhasse cada vez mais peso(no sentido literal?), mesmo que não significativo em comparação a outras cidades do Brasil desta época.

No começo do século XIX, a cidade de São Paulo torna-se capital da província (1822), hospedando o governador e toda a administração pública. O impacto se reflete em obras de melhoramentos urbanos como instalação de iluminação pública (a gás), um novo matadouro, penitenciária, novas ruas pavimentadas, abastecimento de água. Esse desenvolvimento, pequeno mas cumulativo, vem antes do período do café (SINGER, 1968).

O sistema São Paulo-Santos passa a ser o principal exportador de café, no fim do século XIX, mas o período de forte crescimento começa em 1868, um ano depois da inauguração da ferrovia Santos-Jundiaí (1867), operada pela The São Paulo Railway Company Ltd. Contudo, as instalações da grande estação de passageiros no bairro da Luz na cidade de São Paulo entraram em uso somente em 1901.

Em 1875, foram inaugurados os trechos paulistanos das estradas de ferro "do Norte" (hoje "Central do Brasil", linha-tronco) e "Sococabana". Em 1886, foi inaugurada a estrada de ferro São Paulo -Santo Amaro, em 1906 substituída por bondes elétricos. Logo mais seria instalada a linha-tronco do "Tramway da Cantareira", ligando a cidade à serra homônima. Em 1910, um ramal dessa ferrovia atingia Guapira (hoje Jaçanã); o mesmo em 1915 era estendido até a antiga freguesia de Guarulhos, tornada vila em 1880. (Langenbuch, 1971, p. 98)

Essas ligações, por meio da ferrovia, fizeram com que São Paulo exercesse cada vez mais uma força centrípeta em relação aos movimentos demográficos e econômicos do período. Resultado disso é o crescimento da cidade. O que antes era subúrbio vira urbano, o 
que antes era urbano vira centro, e cada vez mais áreas de chácaras viram vilas. Como podemos verificar no mapa seguinte, o núcleo central da cidade, o centro urbano, é demarcado e rodeado por uma área chamada de urbano, que por sua vez é circundada pelo subúrbio. Em destaque, temos as linhas de trem e as linhas de bondes elétricos, cuja densidade na área mais central, até o perímetro urbano, deixa claro que ali era onde se condensava a população e a atividade econômica era mais pujante. O sistema de bondes elétricos se expandiu rapidamente. Em 1900, havia $107 \mathrm{~km}$ de trilhos que, em 1916, saltou para $227 \mathrm{~km}$ de extensão, enquanto que a população saltou de 239.820 para 574.879 habitantes.

\section{Figura 3 - Rede de bondes e trens da cidade de São Paulo, 1913 e 1916}

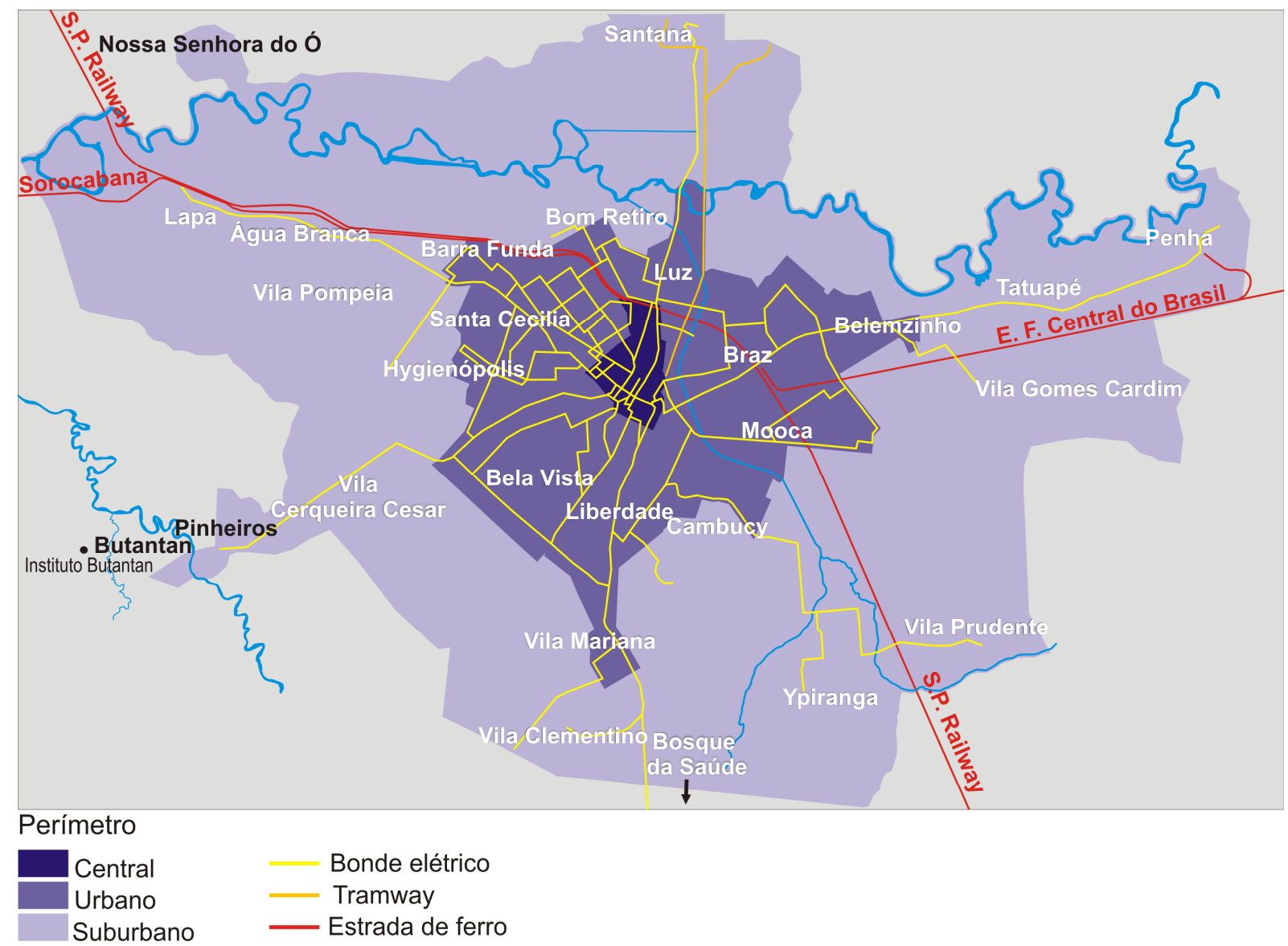

Fonte: Prefeitura Municipal de São Paulo. Planta da Cidade de São Paulo, 1913 e Companhia Light; Planta Geral da Cidade de São Paulo, 1916. Secretaria de Estado de Economia e Planejamento. Instituto Geográfico e Cartográfico - IGC. Acervo - Tombo: 1176 e 1356. In: Prefeitura do Município de São Paulo. Histórico Demográfico. Disponível em: http://smdu.prefeitura.sp.gov.br/historico_demografico.

Adaptação: André de Freitas Gonçalves 
Até o início do século XX, a cidade de São Paulo teria a maior taxa geométrica de crescimento populacional anual dos censos demográficos. De 1890 a 1900, essa taxa foi de 14\%, com o número de habitantes passando de 64.934 para 239.820 habitantes. O recenseamento mostrou que a população paulistana passara a crescer a taxas elevadas. A razão para isso estava no grande número de imigrantes que aqui se fixavam. Para o censo de 1890 foram criados os seguintes "districtos": Norte e Sul (que correspondiam à Parochia de N. S. da Assumpção da Sé); Santa Ephigenia e Santana (englobando a parochia de N. S. da Conceição de Santa Ephigenia); Consolação (N. S. da Consolação de S. João Baptista); Braz (Senhor Bom Jesus de Matosinhos do Braz); N. S. do Ó (N. S. da Expectação do Ó); e Penha de França (N. S. da Penha de França). Nesse Censo, já não faziam parte do Município de São Paulo as Parochias de N. S. da Conceição de Guarulhos, N.S. da Conceição de São Bernardo e N. S. do Desterro do Juquery que, mais tarde, passaram a integrar outros municípios ao redor da cidade de São Paulo. Antigas chácaras ao redor do núcleo histórico da cidade eram loteadas e a área urbana se expandia continuamente. Ferrovias faziam a ligação com o interior, onde se produzia o café, e com o porto de Santos, por onde ele era exportado. São Paulo se firmava como o mais dinâmico centro comercial e financeiro da Província.

Esse crescimento foi acompanhado pela criação de ligações de transporte. As estações ferroviárias produziam uma polarização da industrialização e do povoamento suburbano, que foram determinantes para o surgimento do que seriam os "embriões" de importantes núcleos suburbanos da atualidade, assim achados de "povoados-estação" (LANGENBUCH, 1971). Segundo o mesmo autor, os ônibus serviam os novos "bairros" ou loteamentos até as estações férreas ou aos bondes, e que as atuais rodovias substituem antigos caminhos e rotas, demonstrando que a polaridade da cidade foi construída durante toda sua história, podendo ser explicada a partir de sua formação socioespacial.

Segundo Langenbuch (1971), as rodovias não tiveram o mesmo efeito de produzir subúrbios tal qual as ferrovias, num processo diferente daquele apresentado por Peter Hall (2007), em que as novas estradas alcançavam terras onde os trólebus ou transporte sobre trilhos não chegava. Contudo, há outros elementos apresentados por Hall, como o zoneamento dos usos do solo, que produzia áreas residenciais uniformes com valores imobiliários estáveis, e a pressão demográfica, no caso de São Paulo gerada pela migração e não pela explosão de natalidade. 


\section{Dinâmica demográfica metropolitana e intra-urbana}

Em meados do século XIX e até os anos 1980 do século XX, a cidade de São Paulo teve grandes contingentes de migrantes que contribuíram com o elevado crescimento populacional e da área urbanizada da cidade.

Dentro do processo de migração, podemos destacar que no primeiro momento os imigrantes europeus formaram o principal fluxo que contribuiu com o crescimento populacional da cidade. Isso se deu principalmente em função da necessidade de mão de obra para a produção cafeeira. O que acontece na cidade de São Paulo reflete uma dinâmica econômica e demográfica mais ampla que alcança o nível estadual e nacional, como podemos verificar no gráfico a seguir. Há variação negativa no número de imigrantes no período da I Guerra Mundial e depois com a crise da superprodução do café em 1930, fazendo com que o governo brasileiro impusesse restrições à imigração, que só voltaria a crescer após a II Guerra Mundial, com o desenvolvimento da indústria.

Em um segundo momento, ganhou importância a migração interna, entre regiões do Brasil, na composição da população da cidade de São Paulo. Esses movimentos migratórios aconteceram concomitantemente ao processo de industrialização e urbanização do país (SINGER, 1973). No início da industrialização, o imigrante europeu teve participação destacada por sua grande participação na população da cidade. Contudo, com o tempo, o processo de industrialização produziu uma forte demanda por mão de obra que já não era possível suprir com a imigração, ganhando força o processo de migração interna.

A participação dos residentes não naturais na cidade de São Paulo foi crescendo até 1980 , quando alcançou o número de 4.323 .444 de habitantes ${ }^{15}$, ou seja, cerca de $51 \%$ da população da cidade na época. $\mathrm{O}$ maior contingente desses migrantes era da região nordeste do país, seguido de perto das cidades do estado de São Paulo.

${ }^{15}$ Conforme dados do Censo Demográfico de 1980 do Instituto Brasileiro de Geografia e Estatística. 


\section{Gráfico 1 - Imigrantes no Brasil e no Estado de São Paulo, 1872-1972}

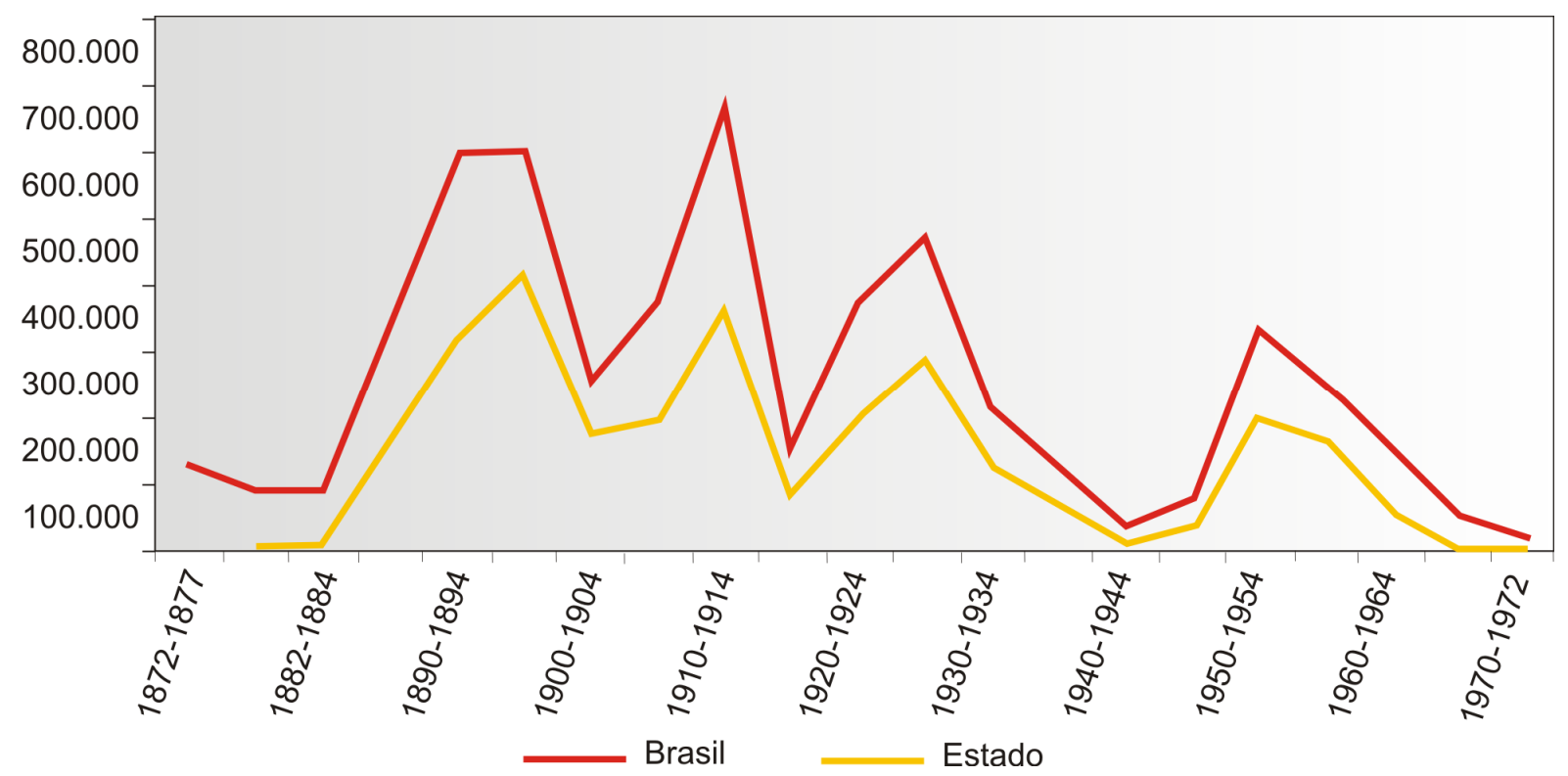

Fonte: BASSANEZI, Maria; SCOTT, Ana; BACELLAR, Carlos; TRUZZI, Oswaldo. Atlas da Imigração Internacional em São Paulo, 1850-1950. São Paulo, Editora Unesp, 2008, p. 19. Adaptação: André de Freitas Gonçalves, 2012.

Verificamos que o crescimento da cidade se deu de maneira explosiva, acelerada e guiada por uma força centrípeta dos movimentos migratórios, tanto internos ao país quanto externos. Isso significa que a população de São Paulo, aproximadamente, se multiplicou por dez nos primeiros cinquenta anos do século XX e por cindo nos outros cinquenta, respectivamente passando de 239.820 habitantes em 1900 para 2.198 .096 em 1950 e para 10.434.252 em 2000. Esse crescimento começa a desacelerar nos anos 80, como podemos verificar no gráfico 2, quando as taxas de crescimento anual da população chegam a registrar $1,2 \%$ contra $3,7 \%$ do período anterior, e caem para menos de $1 \%$ chegando a $0,76 \%$ na primeira década do século XXI. Isso está associado, em parte, com a crise econômica da década de 80 e a recessão da década de 90 , junto com o processo de reestruturação produtiva da economia que afeta diretamente a forma de organização da indústria (BAENINGER, 2005). Outro fator que elucida a queda das taxas de crescimento e saldos migratórios negativos na cidade é o processo de valorização do espaço urbano, que promove o espraiamento da população para as margens da cidade e para municípios vizinhos na Região Metropolitana de São Paulo. Somado a esses fatores, temos a diminuição do crescimento 
vegetativo, devido à queda nos índices de fertilidade e de natalidade observada não apenas em São Paulo, mas também na população brasileira em geral.

\section{Gráfico 2 - Taxas de crescimento anual da população residente, Região Metropolitana e Município de São, Paulo, 1940-2010}

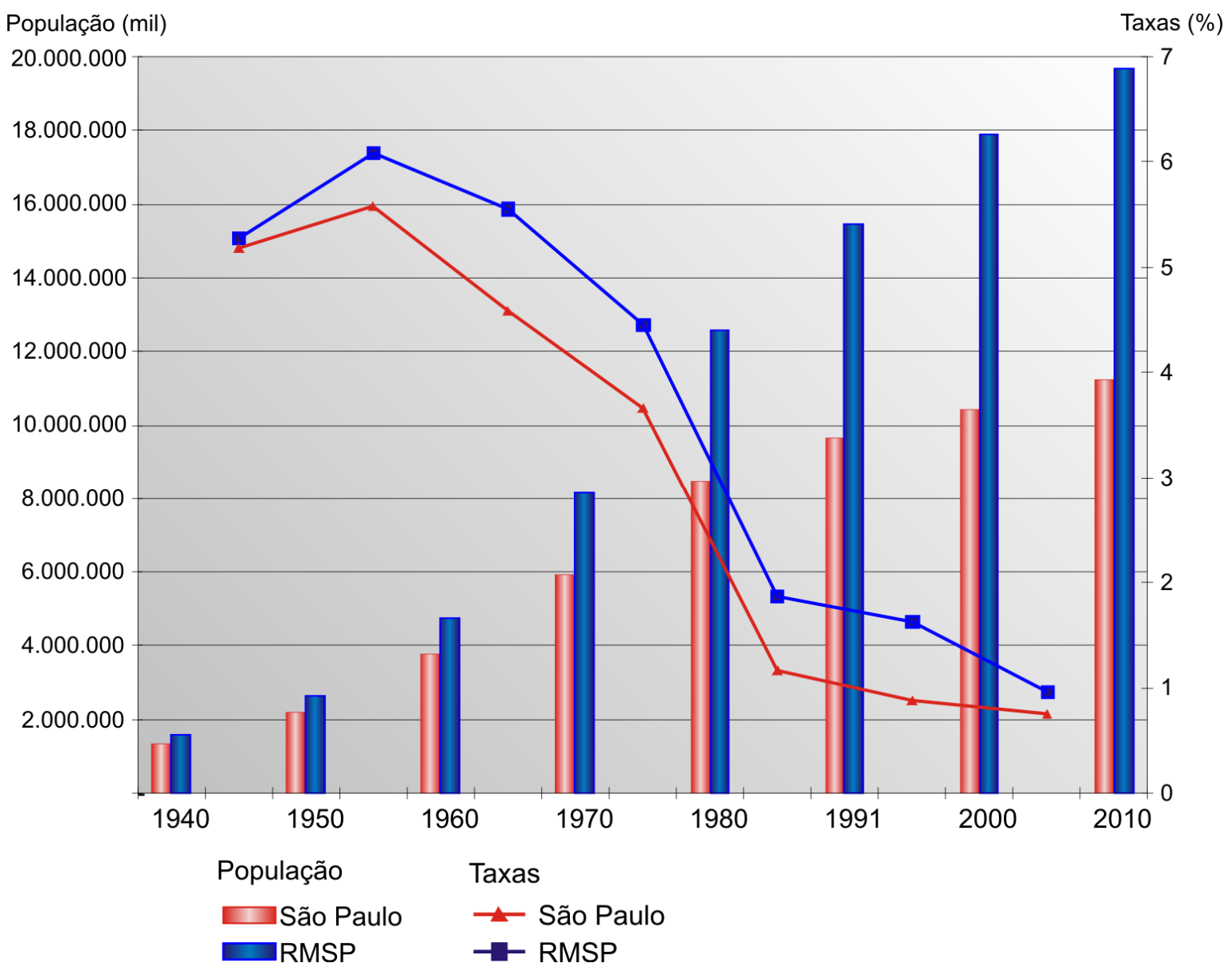

Fonte: IBGE - Censos Demográficos.

O processo de valorização do espaço urbano, que foi descrito como um dos fatores para a queda das taxas de crescimento populacional da cidade, é também responsável, em grande medida, de outro processo que é muito caro à organização socioespacial da cidade, o qual é a periferização do crescimento demográfico.

Ao analisarmos a distribuição da população da cidade nos últimos 60 anos, verificamos que houve uma alteração no padrão espacial de distribuição, que antes se concentrava em distritos centrais da cidade e, a partir da década de 1970, começou a se adensar nos distritos periféricos, com taxas cada vez maiores de crescimento populacional, conforme mapa seguinte. 
Mapa 2 - População do Município de São Paulo, 1950-1970

1970

5.924.615 habitantes

1960

3.667.899 habitantes

1950

2.151.313 habitantes
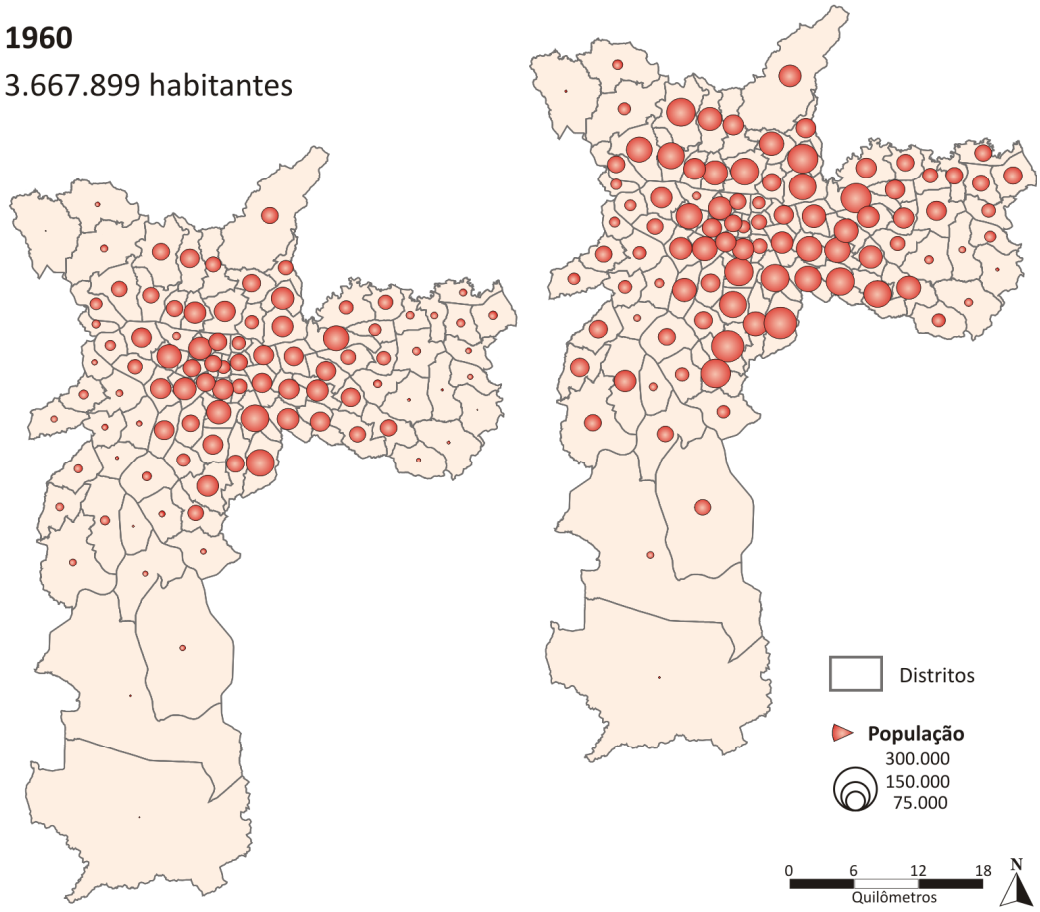

Fonte: IBGE - Censos Demográficos, 1950, 1960 e 1970; Sempla/Dipro - Retroprojeção para distritos municipais 


\section{Mapa 3 - População do Município de São Paulo, 1980 - 2000}

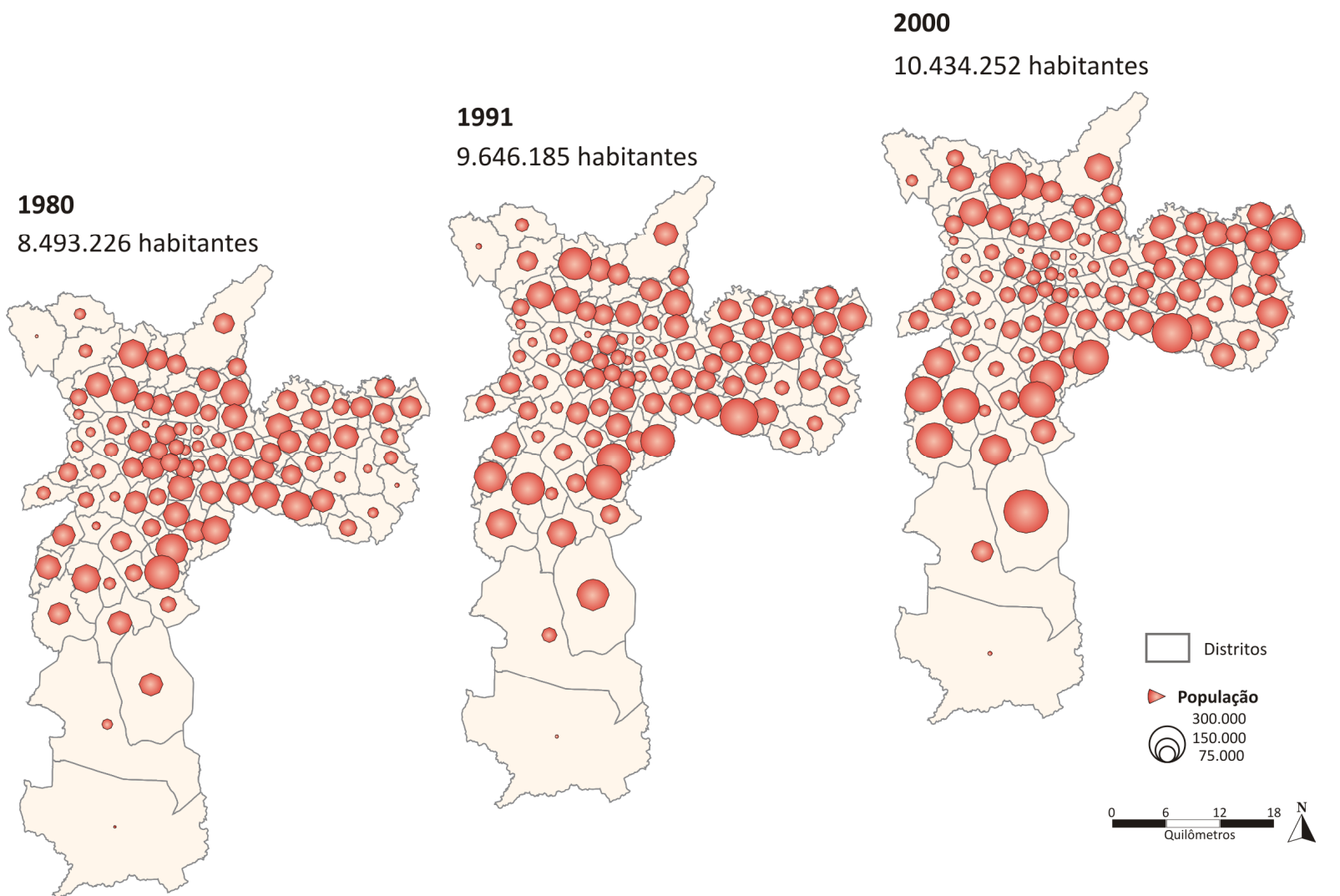

Fonte: IBGE - Censos Demográficos, 1980, 1991 e 2000.

Em função desse processo de periferização e valorização do espaço urbano, por cerca de vinte anos, compreendidos entre 1980 e 2000, verificou-se queda na população absoluta na porção central da cidade, marcando uma tendência demográfica que atingiu o conjunto do centro expandido e ampliou-se até uma faixa limítrofe nas zonas leste, norte e sul. Essa perda de população mostrou-se nítida no período intercensitário de 1980-1991, quando 40 distritos apresentaram taxas negativas de crescimento, o que se acentuou e se espraiou pelo território na década seguinte, atingindo em 2000 um total de 53 distritos. Já em 2010, os dados indicaram um estancamento dessa tendência: os distritos que mais perderam população, entre 1991 e 2000, tiveram crescimento positivo na última década, com destaque para os da região central: Pari (-3,95\% a.a., no período 1991-2000, para 1,56\% a.a., na década 20002010), Bom Retiro (de -3,35\% a.a. para 2,45\% a.a.), Sé (de -3,29\% a.a. para 1,63\% a.a.) e Brás (de -3,14\% a.a. para 1,52\% a.a.). Vale ressaltar que o distrito do Brás vinha apresentando taxas negativas desde a década de 1950. Outros distritos, entre eles, Vila Medeiros (de -1,16\% a.a., no período 1991-2000, para -0,78\% a.a., na década 2000-2010), São Miguel (de -0,62\% 
a.a. para $-0,56 \%$ a.a.), Artur Alvim (-0,71\% a.a. para -0,55\% a.a.) e Santana (de $-1,10 \%$ a.a. para $-0,48 \%$ a.a.) continuaram a perder população, mas em ritmo bem menos acelerado (ver Mapa 1).

As maiores taxas anuais de crescimento da população paulistana foram registradas em Vila Andrade (5,6\% a.a.), Anhanguera (5,54\% a.a.), Vila Leopoldina (3,92\% a.a.) e Morumbi (3,1\% a.a.), sendo que os dois primeiros (Vila Andrade e Anhanguera), desde os anos 1980, estão entre os cinco distritos com os maiores níveis de incremento demográfico. A chegada dos novos contingentes populacionais a esses quatro distritos esteve associada a situações diversas em relação à tipologia de habitação: Vila Andrade foi o distrito municipal que sofreu o maior nível de verticalização e teve o maior acréscimo de área construída do tipo residencial, entre os anos de 2002 e 2009. Por outro lado, abriga a segunda maior favela da cidade - Paraisópolis. No mesmo período, Vila Leopoldina teve grande acréscimo de área construída residencial (64,5\%), mas exclusivamente do tipo vertical (houve, até mesmo, diminuição da área construída horizontal), enquanto no distrito de Anhanguera predominou a expansão do tipo horizontal, em moradias destinadas a contingentes de baixa renda. Já o Morumbi foi o distrito com o maior acréscimo de área construída horizontal do município (261.386 $\mathrm{m}^{2}$ entre 2002 e 2009), mas registrou um nível de verticalização ainda maior $\left(280.141 \mathrm{~m}^{2}\right)$.

Um fator importante que contribui para essa mudança na dinâmica demográfica intraurbana da cidade é o mercado imobiliário. Segundo dados da Empresa Brasileira de Estudos Patrimoniais (Embraesp), no período de 1997 a 2007, o número de unidades residenciais verticais lançadas em todo o município foi de 285 mil. Só no centro expandido foram lançadas 118 mil unidades, ou seja, cerca de 40\%. As subprefeituras que obtiveram melhor desempenho em unidades lançadas, respectivamente, foram Lapa, Pinheiros, Sé e Mooca, todas na área central da cidade. 
Mapa 4 - Taxas de crescimento anual da população, Município de São Paulo
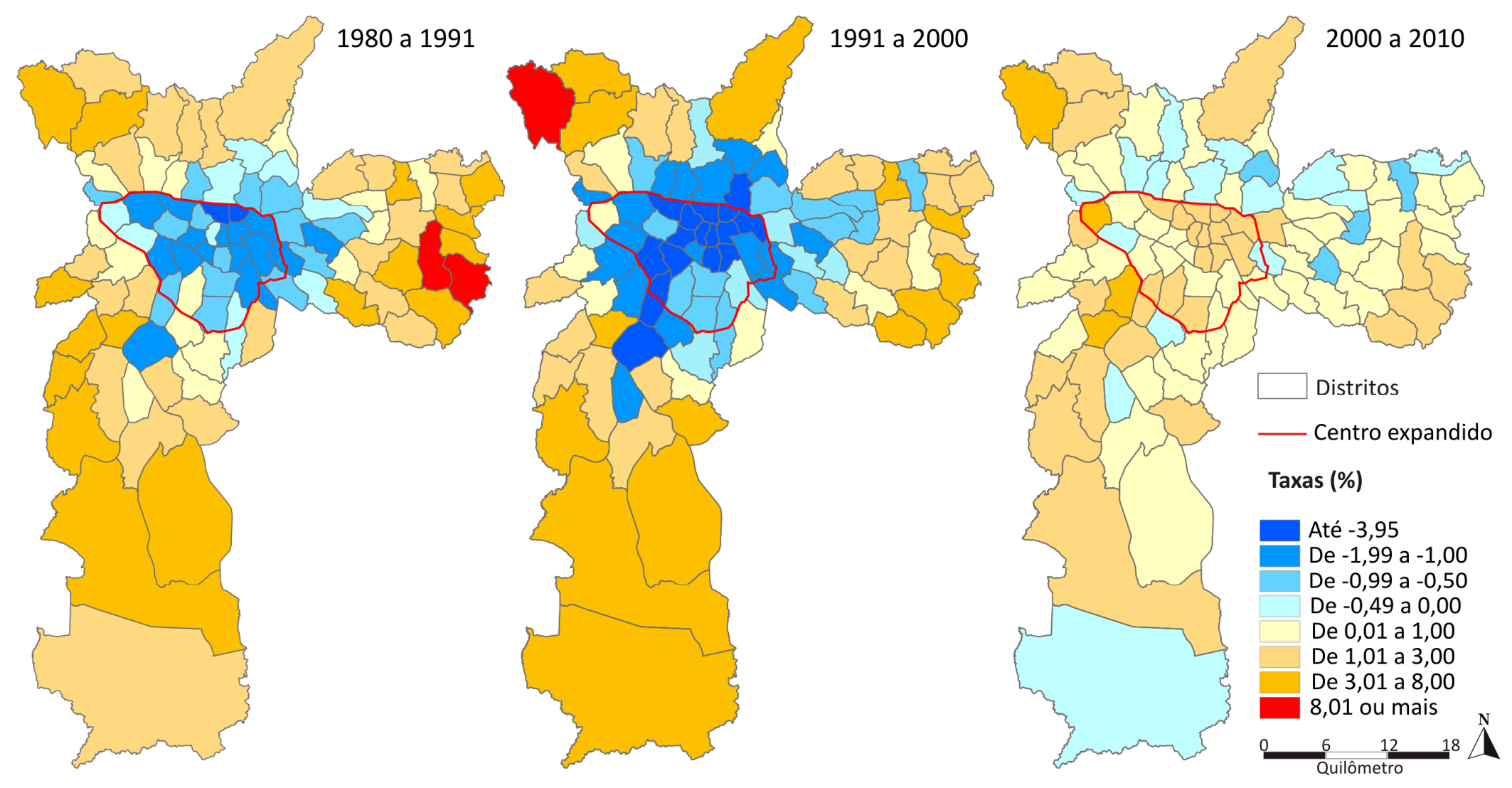

Fonte: IBGE - Censos demográficos 1980, 1991, 2000 e 2010.

Elaboração: André de Freitas Gonçalves 
Na última década, o município de São Paulo registrou taxa média anual de crescimento da população de $0,76 \%$, percentual menor quando comparado ao do período anterior $(0,88 \%)$. Isso se traduziu, no entanto, em um acréscimo populacional de 819.251 habitantes, número superior à população do quarto maior município do estado de São Paulo, São Bernardo do Campo, com 765.463 habitantes em 2010. Esse acréscimo populacional é resultado do elevado saldo vegetativo: 1.779 .618 de nascimentos contra 673.476 óbitos entre 2001 e 2010, o que significou um saldo de 1.106.142 pessoas, segundo dados do Datasus (Ministério da Saúde), uma vez que o saldo migratório deixou de ser um fator determinante para o crescimento populacional em São Paulo desde a década de 1980, quando se registrou negativo de 684 mil pessoas, passando para um saldo negativo de 454 mil pessoas entre 1991 e 2000 (WALDVOGEL, 2004) e, por fim, a um saldo negativo de 287 mil pessoas entre 2000 e 2010. Cabe ressaltar que essa evasão populacional vem diminuindo, mas quando observamos o nível intraurbano, verificamos a importância de novos imigrantes, no crescimento populacional de alguns distritos centrais, como Bom Retiro ou Pari.

A densidade demográfica média no município de São Paulo, segundo o Censo de 2010, era de 74,58 habitantes por hectare, resultado da distribuição dos mais de 11 milhões e 250 mil residentes pelo território de $1.509 \mathrm{~km}^{2}$ do município. É na região central que se localizam três dos cinco distritos municipais com as maiores densidades demográficas: Bela Vista (267,15 hab./ha), República (247,74 hab./ha) e Santa Cecília (214,66 hab./ha), além de Cidade Ademar (222,23 hab./ha) e Sapopemba (210,76 hab./ha), nas regiões sul e leste, respectivamente. Por outro lado, no extremo sul, os distritos de Marsilac (0,41 hab./ha) e Parelheiros (8,55 hab./ha) continuam como os menos povoados do município, seguidos por Anhanguera (19,78 hab./ha), Barra Funda (25,68 hab./ha) e Socorro (29,29 hab./ha). Esses dados refletem não apenas o tamanho do contingente demográfico que reside em cada um deles, mas também a extensão territorial do distrito. Assim, densidades mais elevadas poder ser observadas tanto em distritos mais centrais, com ocupação verticalizada, quanto em alguns distritos periféricos, com intenso parcelamento do solo e com predomínio de famílias com maior número de membros. 


\section{Mapa 5 - Mapa - densidade demográfica 2010}

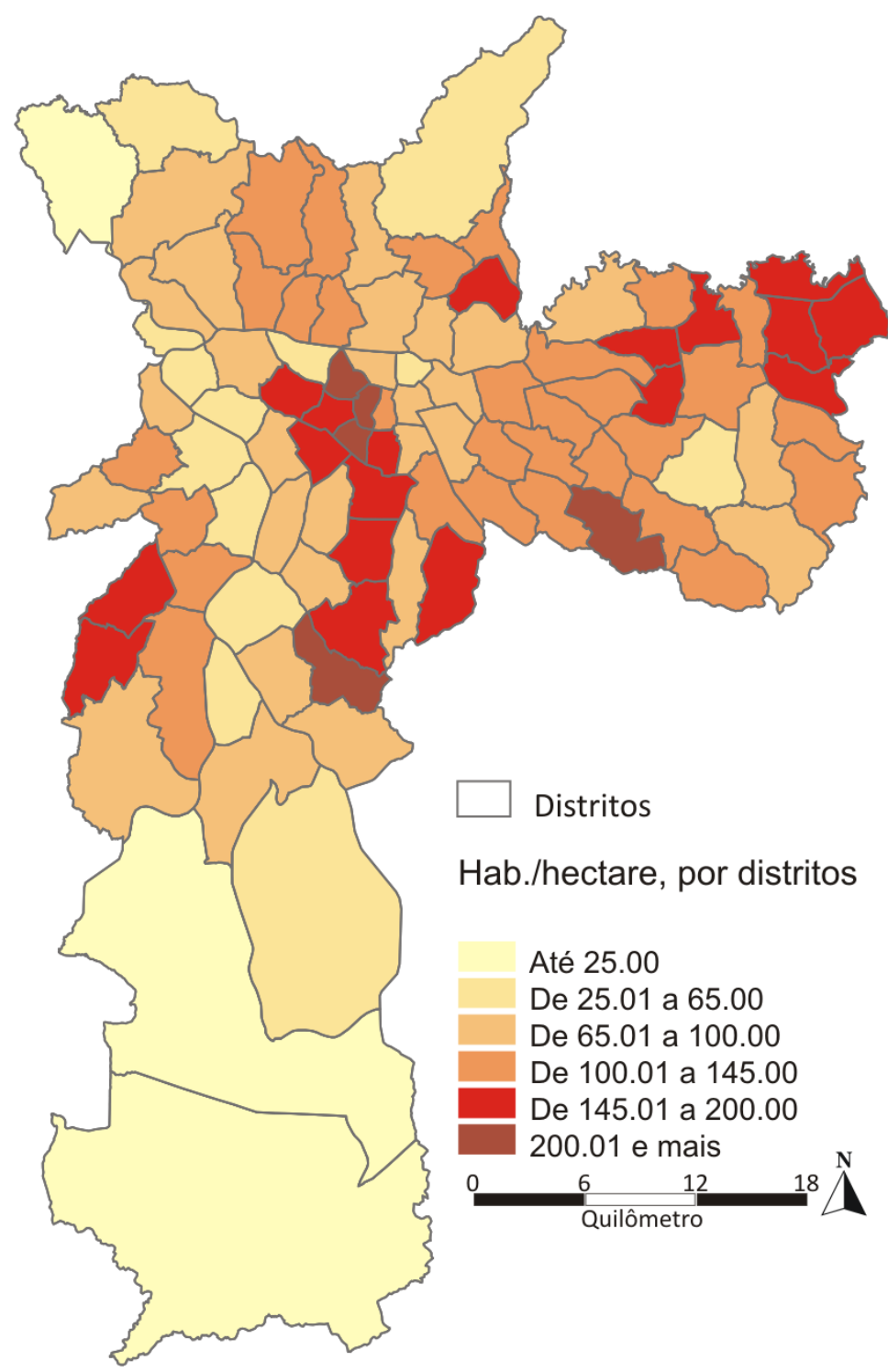

Fonte: IBGE. Censos Demográficos, 2010.

Elaboração: André de Freitas Gonçalves

A análise da distribuição espacial da população paulistana no ano de 2010 ainda ressalta o padrão que se desenhou especialmente a partir da década de 1970, quando os distritos periféricos começaram a se tornar mais populosos que os distritos centrais, gerando com isso um amplo espraiamento da mancha urbana.

Os distritos mais populosos estão em áreas periféricas onde se localizam também importantes áreas de preservação ambiental, como podemos verificar no mapa 6. Os dois maiores distritos em número de habitantes, Grajaú (360.787 hab.) e Jardim Ângela (295.434 hab.) situam-se dentro dos limites da área de proteção aos mananciais. Já o distrito de 
Brasilândia, com 264.918 habitantes e localizado ao norte, nas encostas da Serra da Cantareira, é outro exemplo das fortes implicações ambientais desse padrão de urbanização. São áreas onde predominam os assentamentos precários, sejam favelas ou loteamentos irregulares, habitados por população que enfrenta difíceis condições de vida e de acesso a serviços públicos.

\section{Mapa 6 - Mapa população 2010}

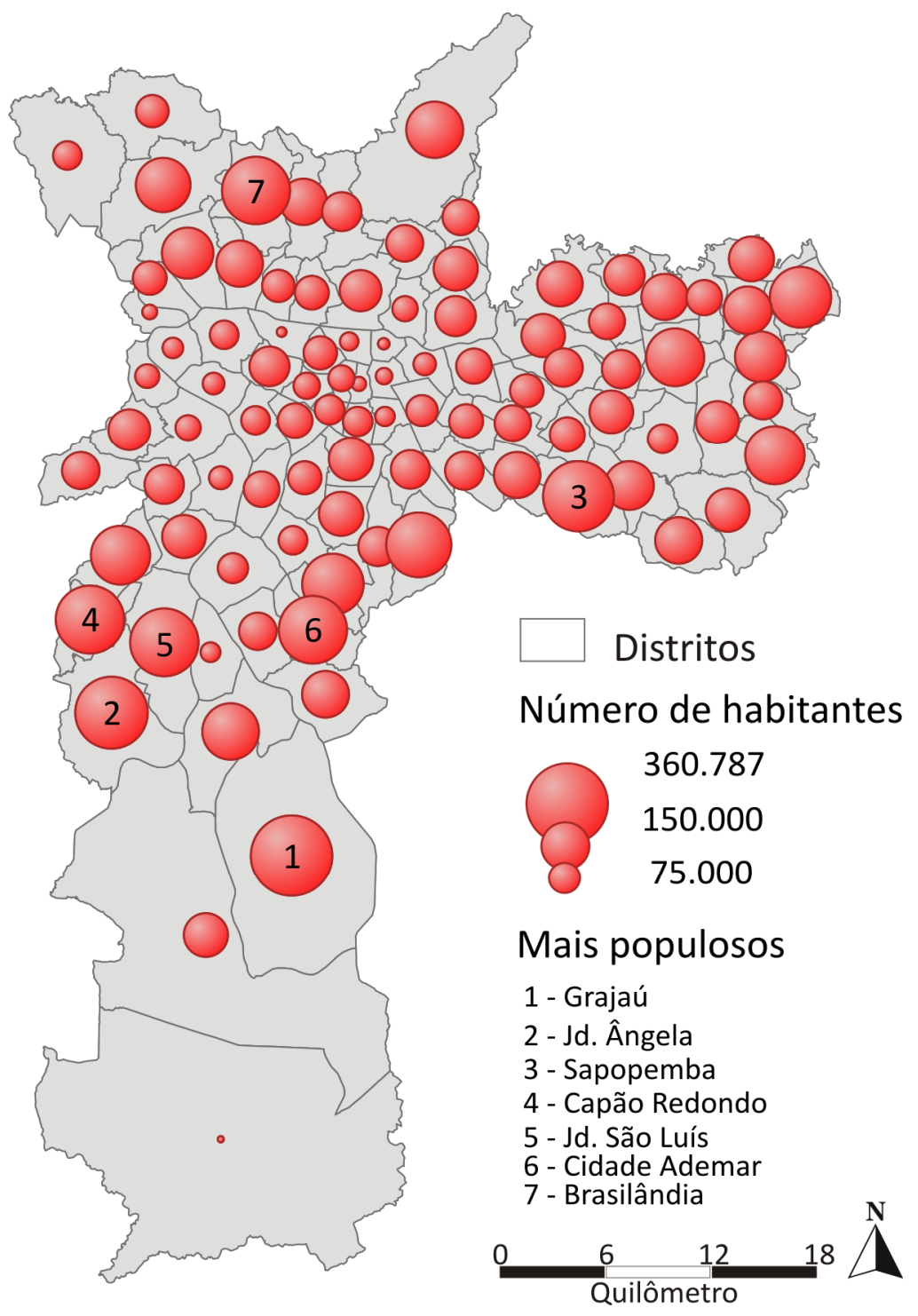

Fonte: IBGE - Censos Demográficos, 2010

Elaboração: André de Freitas Gonçalves

$\mathrm{Na}$ tipologia dos distritos municipais, comparamos a evolução das taxas de crescimento populacional de dois períodos: 1991 a 2000 e 2000 a 2010. Na somatória, o Tipo 
1 (distritos onde as taxas de crescimento ainda são negativas) obteve decréscimo populacional de -48.165, enquanto o Tipo 2 (novos distritos negativos) -9.154 habitantes. O Tipo 3, num total de 38 distritos, refere-se aos novos distritos positivos, que tiveram acréscimo populacional de 244.298 habitantes e deixaram de apresentar taxas de crescimento populacional negativas. Há, também, o Tipo 4, distritos que continuam com crescimento positivo e somam acréscimo total de 632.272 habitantes.

\section{Mapa 7 - Mapa Tipologia dos distritos, segundo comparação das taxas de crescimento}

\section{da população 1991/2000 e 2000/2010}

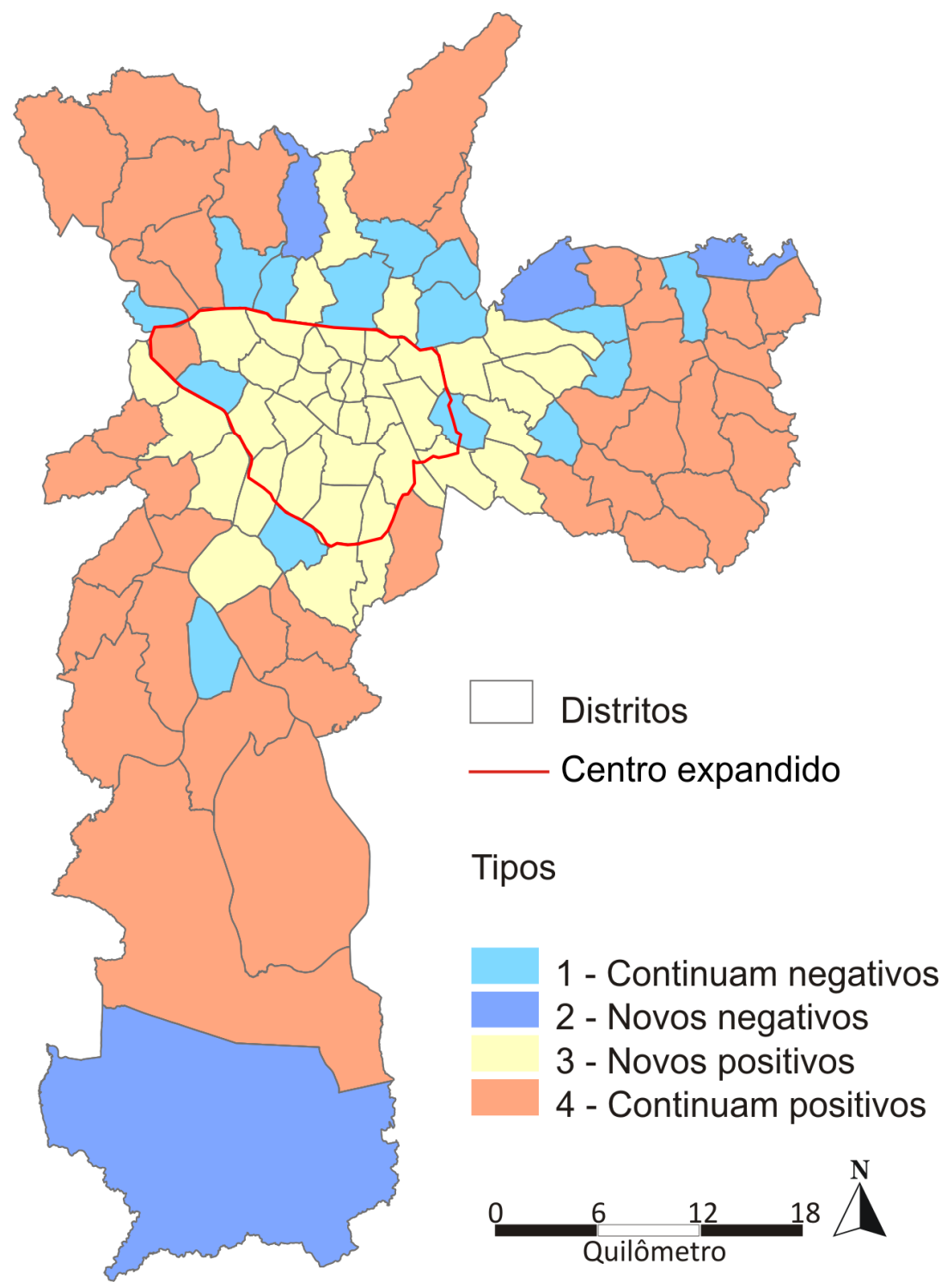

Fonte: IBGE - Censos Demográficos, 2000 e 2010

Elaboração: André de Freitas Gonçalves 
Em síntese, pode-se afirmar com base nos dados censitários, que a área mais consolidada da cidade, aquela que apresenta densa rede de infraestrutura de transportes e serviços, voltou a registrar taxas positivas de crescimento populacional. O chamado centro expandido da cidade voltou a crescer. Nessa área, com exceção de dois distritos (Alto de Pinheiros e Água Rasa), todos os demais apresentaram taxas de crescimento demográfico positivas, o que resultou em acréscimo de aproximadamente 175 mil habitantes no período 2001-2010. Quando o foco é apenas a Subprefeitura da Sé, composta pelos dez distritos mais centrais, observa-se um acréscimo de 57.192 habitantes no período. 


\section{Dinâmicas produtivas}

Antes de analisarmos o processo produtivo na cidade de São Paulo, faremos uma breve explanação sobre a reestruturação econômica e produtiva que aconteceu nas últimas décadas do século XX.

A partir dos anos 1970, tal reestruturação econômica e produtiva se tornou mais clara, passando a vigorar em todo o país. Ela seria responsável por transformações territoriais significativas nos espaços urbanos, principalmente os das grandes cidades. O setor econômico responsável pelo início dessas transformações foi o industrial. Mudanças nos padrões organizacionais e tecnológicos ocorreram a princípio nas indústrias movidas pelo contexto econômico internacional e posteriormente o setor de serviços se transformou para se integrar esse movimento. O processo de terceirização da mão de obra, somado com o uso intensivo de técnicas da informação, é a característica mais visível da reestruturação produtiva e organizacional das empresas. Por meio de uma constante cooperação interfirmas, elas constroem uma hierarquização de suas cadeias produtivas e comerciais, resultando em diferentes modalidades de subcontratação ou terceirização (MATTEO \& BESSA, 2002). A terceirização consiste na transferência de muitas atividades controladas e produzidas dentro da indústria para o setor de serviços (SASSEN, 1991; DINIZ \& DINIZ, 2004). Tal fenônemo explica o avanço desse último setor(SASSEN, 1998).

Ao contrário do que se passou em diferentes lugares do mundo, a exemplo do nordeste dos Estados Unidos e noroeste da Inglaterra, onde a redução da produção e do emprego industrial foi acompanhada por inúmeros fechamentos de plantas industriais e tal crise atingiu os demais setores da economia, provocando queda generalizada da produção e emprego, como também fortes processos migratórios (DINIZ \& DINIZ, 2004), na Região Metropolitana de São Paulo, entre outras diferenças a mais emblemática é que:

(...) a queda do emprego na indústria foi mais que compensada pelo aumento do emprego nos setores de comércio e serviços, indicando uma forte reestruturação produtiva, e não um processo de desindustrialização como ocorrido nos Estados Unidos e na Inglaterra. Além disso, e coerente com a 
expansão do setor de serviços, a reestruturação industrial se fez com altos ganhos de produtividade e com transferência de muitas atividades controladas e produzidas dentro da indústria para o setor de serviços, a chamada terciarização. (DINIZ \& DINIZ, 2004, p. 72)

Em associação a esse processo, está o surgimento de novas atividades econômicas, principalmente ligadas à prestação de serviços, que promovem o apoio de toda a cadeia produtiva, comercialização de serviços, administração de banco de dados e de fluxos informacionais, entre outros. No período atual, o desenvolvimento da técnica da informação possibilitou uma coordenação global de todas as técnicas. Esse atributo é dirigido pelas empresas que mantém o controle de todos os setores de produção independente de onde estejam localizados. A cidade de São Paulo dentro desse contexto reafirma sua primazia e:

"reúne cerca de $80 \%$ das sedes de empresas com cisão territorial. Considerando-se os demais municípios da região metropolitana, essa cifra passa para $86,5 \%$, e, se levarmos em conta a área compreendida em um raio de pouco mais de 250 quilômetros de extensão a partir do centro metropolitano, esse índice passa para 93,1\%. Esse conjunto formado pela região metropolitana e seu entorno, com fortes vínculos internos, é denominado aglomerado metropolitano. Nesse aglomerado é que o movimento de desconcentração e de reconcentração produtiva atua com todo seu dinamismo, pois aí estão instalados os novos requisitos locacionais da atividade industrial, tais como: ciência e tecnologia, informação, mão de obra especializada e instituições de desenvolvimento" (LENCIONI, 2003, p. 467).

Podemos observar na tabela a seguir que o município de São Paulo tem participação expressiva em número de empregos e estabelecimentos industriais de determinados subsetores de atividade econômica em comparação ao total de empregos e estabelecimentos no Brasil. Merece destaque a indústria do papel, papelão, editorial e gráfica com 14,7\% do emprego em relação ao total de empregos desse subsetor no Brasil, materiais elétricos e de comunicações com $11,2 \%$ e a indústria têxtil de vestuário e artefatos de tecidos com 10,2\%. 
Tabela 1 - Estabelecimentos e Empregos Formais por Subsetor de Atividade Econômica, Brasil, Região Metropolitana e Município de São Paulo, 2010

\begin{tabular}{|c|c|c|c|c|c|c|c|c|c|c|}
\hline \multirow{3}{*}{ Subsetor de Atividade Econômica } & \multirow{2}{*}{\multicolumn{2}{|c|}{ Brasil }} & \multicolumn{4}{|c|}{ Região Metropolitana de São Paulo } & \multirow{2}{*}{\multicolumn{2}{|c|}{$\begin{array}{c}\text { Participação no Brasil } \\
\text { Munic São Paulo }\end{array}$}} & \multirow{2}{*}{\multicolumn{2}{|c|}{$\begin{array}{c}\text { Participação no Brasil } \\
\text { Total RMSP }\end{array}$}} \\
\hline & & & \multicolumn{2}{|c|}{ Total RMSP } & \multicolumn{2}{|c|}{ Munic São Paulo } & & & & \\
\hline & Estab/os & Empregos & Estab/os & Empregos & Estab/os & Empregos & Estab/os & Empregos & Estab/os & Empregos \\
\hline Inđústria de produtos minerais não metálicos & 24.006 & 410.734 & 1.072 & 35.057 & 462 & 13.233 & 1,9 & 3,2 & 4,5 & 8,5 \\
\hline Inđústria metalúrgica & 41.269 & 796.617 & 6.360 & 158.733 & 3.290 & 63.982 & 8,0 & 8,0 & 15,4 & 19,9 \\
\hline Inđústria mecânica & 20.742 & 566.490 & 3.831 & 105.427 & 2.076 & 52.816 & 10,0 & 9,3 & 18,5 & 18,6 \\
\hline Inđústria do material elétrico e de comunicações & 6.728 & 281.779 & 1.874 & 69.384 & 1.173 & 31.538 & 17,4 & 11,2 & 27,9 & 24,6 \\
\hline Indústria do material de transporte & 6.914 & 583.777 & 1.312 & 141.647 & 638 & 31.426 & 9,2 & 5,4 & 19,0 & 24,3 \\
\hline Indústria da madeira e do mobiliảrio & 34.944 & 468.744 & 2.005 & 31.552 & 1.210 & 12.623 & 3,5 & 2,7 & 5,7 & 6,7 \\
\hline Inđústria do papel, papelão, editorial e gráfica & 25.932 & 406.074 & 4.863 & 108.279 & 3.450 & 59.576 & 13,3 & 14,7 & 18,8 & 26,7 \\
\hline Indústria da borracha, fumo, couros, peles, similares, ind. diversas & 17.482 & 327.271 & 3.145 & 72.966 & 2.150 & 29.656 & 12,3 & 9,1 & 18,0 & 22,3 \\
\hline Ind. quimica de produtos farmacêuticos, veterinários, perfumaria... & 25.148 & 902.703 & 5.588 & 216.415 & 2.804 & 89.697 & 11,1 & 9,9 & 22,2 & 24,0 \\
\hline Indústria têxtil do vestuário e artefatos de tecidos & 66.206 & 1.036 .949 & 10.331 & 146.722 & 8.709 & 105.793 & 13,2 & 10,2 & 15,6 & 14,1 \\
\hline Indústria de calçados & 10.351 & 348.691 & 152 & 3.440 & 123 & 2.622 & 1,2 & 0,8 & 1,5 & 1,0 \\
\hline Indústria de produtos alimenticios, bebidas e álcool etilico & 57.929 & 1.755 .873 & 4.619 & 138.546 & 2.935 & 85.538 & 5,1 & 4,9 & 8,0 & 7,9 \\
\hline Total Indústria & 337.651 & 7.885 .702 & 45.152 & 1.228 .168 & 29.020 & 578.500 & 8,6 & 7,3 & 13,4 & 15,6 \\
\hline Total & 3.403 .448 & 44.068 .355 & 389.678 & 7.166 .407 & 270.123 & 4.873 .339 & 7,9 & 11,1 & 11,4 & 16,3 \\
\hline
\end{tabular}

Fonte: Ministério do Trabalho e Emprego. Relação Anual de Informações Sociais (Rais)

Elaboração: PMSP/SMDU/Dipro 
No geral, o município de São Paulo tem participação de 7,3\% no emprego industrial do país e 8,6\% dos estabelecimentos indústriais, segundo a Relação Anual de Informações Sociais (Rais) do Ministério do Trabalho e Emprego.

Essa comparação torna-se mais expressiva quando realizada a partir dos dados da Região Metropolitana de São Paulo em relação ao Brasil, mostrando uma forte concentração de determinados subsetores da indústria, ainda que essa participação tenha diminuído. No total, a Região Metropolitana participa e concentra 15,6\% dos empregos industriais do Brasil, com destaque para a indústria do papel, papelão, editorial e gráfica com 26,7\% do emprego, o subsetor industrial de materiais elétricos e de comunicações com $24,6 \%$, e indústria química de produtos farmacêuticos, veterinários, perfumaria com $24 \%$ do total de empregos. Cabe ressaltar que os subsetores são praticamente os mesmos de destaque para o município de São Paulo com exceção do último, indústria química de produtos farmacêuticos, veterinários, perfumaria, que não aparece como destaque na comparação com o Brasil, mas que dentro do município de São Paulo, isto é, comparando com o total de empregos industriais do município, representa $15,5 \%$, e o coloca em segundo lugar de importância, perdendo somente para o subsetor da indústria têxtil do vestuário e artefatos de tecidos com 18,3\% do total de empregos industriais na cidade de São Paulo.

Esses números colocam em evidência que mesmo sofrendo um processo de desconcentração industrial e o setor de serviços crescendo com sua participação dentro da atividade econômica do município, São Paulo continua uma cidade com forte presença industrial. Quando enxergamos São Paulo como núcleo de um aglomerado metropolitano, essa importância tende a aumentar.

A concentração da indústria da cidade e Região Metropolitana de São Paulo (RMSP) pode ser aferida por meio do valor da produção. Ao analisarmos a participação do Valor Adicionado Fiscal de subsetores da indústria, na tabela seguinte, tanto do município quanto da Região Metropolitana, em relação ao total do estado de São Paulo, verificamos a importante concentração industrial de determinados subsetores da indústria. Com especial destaque para os subsetores: edição, impressão e gravações com 55,40\% no município e 86,85\% na RMSP, vestuário e acessórios com 53,73\% no município e 67,03\% na RMSP, produtos de perfumaria e cosméticos com 32,94\% no município e 78,12\% na RMSP, e equipamentos médicos, óticos, de automação e precisão com 30,52\% no município e 49,57\% na RMSP, tendo com fonte a Secretaria de Estado dos Negócios da Fazenda disponível pela Fundação SEADE. Verificamos elevados percentuais de participação em diferentes subsetores da indústria, 
apontando para uma concentração econômica. Esse processo é entendido por alguns autores como um movimento chamado de dualidade circular $^{16}$, isto é, houve uma desconcentração e reconcentração da atividade industrial. "Não houve movimento linear de desconcentração. Apesar de, na média, ela ter perdido participação na produção industrial, alguns setores se reconcentraram" (CAIADO, RIBEIRO, AMORIM, 2004, p. 133)

Tabela 2 - Participação do Município e Região Metropolitana de São Paulo no Valor Adicionado Fiscal do Estado de São Paulo, 2009

\begin{tabular}{|c|c|c|c|c|}
\hline & & & \multicolumn{2}{|c|}{ (Em reais de 2011) } \\
\hline \multirow[b]{2}{*}{ Setores } & \multicolumn{2}{|c|}{ Municipio de São Paulo } & \multicolumn{2}{|c|}{ Região Metropolitana de } \\
\hline & \begin{tabular}{|c|}
$\begin{array}{c}\text { Valor Adicionado } \\
\text { Fiscal }\end{array}$ \\
\end{tabular} & Participação & $\begin{array}{c}\text { Valor Adicionado } \\
\text { Fiscal }\end{array}$ & Participação \\
\hline Indústria - Total & 43.459 .819 .651 & 12,22 & 132.463 .528 .881 & 37,25 \\
\hline Edição, Impressão e Gravações & 4.520 .575 .540 & $\mathbf{5 5 , 4 0}$ & 7.086 .824 .034 & 86,85 \\
\hline Vestuário e Acessórios & 2.541 .450 .805 & $\mathbf{5 3 , 7 3}$ & 3.170.756.989 & 67,03 \\
\hline Fumo & 24.530 .285 & 36,18 & 66.627 .204 & 98,28 \\
\hline Produtos de Perfumaria e Cosméticos & 841.625 .188 & 32,94 & 1.995 .648 .224 & 78,12 \\
\hline Equipamentos Médicos, Óticos, de Automação e Precisão & 1.201 .288 .227 & 30,52 & 1.951 .206 .719 & 49,57 \\
\hline Produtos de Metal & 3.572.164.637 & 23,29 & 8.635 .774 .432 & $\mathbf{5 6 , 3 0}$ \\
\hline Diversas & 546.712 .597 & 22,09 & 1.376 .824 .729 & 55,62 \\
\hline Máquinas, Aparelhos e Materiais Elétricos & 1.850 .981 .997 & 21,95 & 4.644 .607 .770 & 55,09 \\
\hline Eletrodomésticos & 827.131 .648 & 21,86 & 1.265 .517 .046 & 33,45 \\
\hline Produtos Farmacêuticos & 3.142.535.781 & 18,43 & 12.042 .789 .533 & 70,63 \\
\hline Produtos de Plástico & 2.112 .739 .493 & 18,36 & 6.387 .276 .113 & 55,51 \\
\hline Material Eletrônico e Equipamentos de Comunicações & 896.142 .251 & 17,57 & 1.462 .762 .134 & 28,69 \\
\hline Máquinas e Equipamentos & 3.675 .396 .092 & 15,37 & 9.629 .505 .381 & 40,27 \\
\hline Minerais Não Metálicos & 1.460 .840 .085 & 15,12 & 3.454 .331 .400 & 35,76 \\
\hline Têxtil & 1.027 .914 .669 & 14,51 & 2.536 .304 .533 & 35,79 \\
\hline Produtos Quimicos & 4.295 .709 .134 & 13,62 & 15.552 .021 .034 & 49,29 \\
\hline Artigos de Borracha & 710.864 .925 & 12,75 & 3.029 .604 .705 & 54,33 \\
\hline Metalurgia Básica-Ferrosos & 1.277.479.101 & 10,57 & 3.394 .940 .408 & 28,10 \\
\hline Móveis & 257.548 .901 & 9,87 & 1.071 .353 .516 & 41,05 \\
\hline Extrativa & 191.326 .224 & 9,55 & 909.259 .871 & 45,41 \\
\hline Máquinas para Escritório e Equipamentos de Informática & 528.259 .633 & 9,53 & 612.499 .621 & 11,05 \\
\hline Reciclagem & 32.391 .788 & 9,35 & 109.187 .068 & 31,53 \\
\hline Papel e Celulose & 933.519 .978 & 7,72 & 4.102 .001 .008 & 33,90 \\
\hline Madeira & 117.287 .076 & 6,73 & 306.817 .413 & 17,60 \\
\hline Couros e Calçados & 124.716 .438 & 6,62 & 222.287 .600 & 11,80 \\
\hline Produtos Alimenticios & 3.078 .677 .025 & 6,54 & 5.936 .443 .702 & 12,61 \\
\hline Material de Transporte - Montadoras e Autopeças & 3.329 .958 .772 & 6,01 & 26.205 .054 .366 & 47,29 \\
\hline Metalurgia Básica - Não Ferrosos & 187.098 .514 & 5,74 & 1.373.815.214 & 42,15 \\
\hline Bebidas & 98.409 .363 & 1,22 & 690.423 .457 & 8,53 \\
\hline Combustiveis & 54.543 .486 & 0,13 & 3.241 .063 .654 & 7,61 \\
\hline
\end{tabular}

Fonte: Secretaria de Estado dos Negócios da Fazenda

Elaboração: André de Freitas Gonçalves

${ }^{16}$ O conceito de dualidade circular foi originalmente elaborado por Benko (1996). Ver em: CAIADO, RIBEIRO, AMORIM, 2004, p. 133. 
A indústria paulistana ainda se mantém em lugar de destaque, quando comparamos o Valor Adicionado (VA) dela com os estados da Federação. Na tabela seguinte, verificamos que está em quarto lugar, atrás somente do estado de São Paulo, Rio de Janeiro e Minas Gerais, portanto, na frente de todo o restante do país. Se considerarmos o VA do setor de serviços ou o VA total o município de São Paulo só perde para o estado do qual faz parte.

Tabela 3 - Valor Adicionado por Setores de Atividade Econômica a Preços Correntes, Unidades da Federação e Município de São Paulo, $2009^{(1)}$

\begin{tabular}{|c|c|c|c|c|}
\hline \multirow{3}{*}{ Unidades Tenritoriais } & \multicolumn{4}{|c|}{ Valor Adicionado } \\
\hline & \multirow{2}{*}{$\begin{array}{c}\text { Indústria } \\
\text { (R\$ milhões) }\end{array}$} & \multicolumn{2}{|c|}{ Serviços ( $\mathrm{R} \$$ milhões) } & \multirow{2}{*}{$\begin{array}{c}\text { Total } \\
\text { (R\$ milhões) }\end{array}$} \\
\hline & & $\begin{array}{c}\text { Administração } \\
\text { Pública }\end{array}$ & Total $^{(2)}$ & \\
\hline Estado de São Paulo & $264.690,3$ & $88.830,6$ & $631.932,0$ & $911.386,5$ \\
\hline Rio de Janeiro & $79.444,9$ & $56.677,4$ & $220.603,5$ & $301.539,4$ \\
\hline Minas Gerais & $75.826,2$ & $35.802,0$ & $153.798,1$ & $252.340,2$ \\
\hline Município de São Paulo & $66.864,8$ & $24.172,3$ & $255.757,6$ & $322.647,4$ \\
\hline Rio Grande do Sul & $55.173,9$ & $25.002,9$ & $115.106,2$ & $188.902,5$ \\
\hline Paraná & $46.858,0$ & $18.376,4$ & $106.694,5$ & $166.369,4$ \\
\hline Santa Catarina & $37.213,7$ & $12.967,7$ & $66.877,3$ & $113.332,4$ \\
\hline Bahia & $34.820,7$ & $20.519,3$ & $77.221,2$ & $121.416,4$ \\
\hline Goiás & $20.409,7$ & $9.760,6$ & $44.549,0$ & $75.551,8$ \\
\hline Amazonas & $17.316,9$ & $7.420,1$ & $22.258,2$ & $41.718,7$ \\
\hline Espírito Santo & $16.128,2$ & $8.320,8$ & $34.392,0$ & $54.181,7$ \\
\hline Pará & $15.312,9$ & $10.782,9$ & $33.291,1$ & $52.466,1$ \\
\hline Pernambuco & $14.795,2$ & $16.597,5$ & $49.285,5$ & $67.326,4$ \\
\hline Ceará & $14.220,2$ & $13.234,9$ & $40.830,1$ & $58.011,6$ \\
\hline Mato Grosso & $8.665,0$ & $7.053,0$ & $27.940,4$ & $51.279,1$ \\
\hline Distrito Federal & $7.656,8$ & $64.460,5$ & $108.251,0$ & $116.449,6$ \\
\hline Mato Grosso do Sul & $5.775,0$ & $6.088,7$ & $20.628,3$ & $31.258,5$ \\
\hline Paraíba & $5.731,8$ & $8.108,0$ & $18.720,0$ & $25.926,3$ \\
\hline Maranhão & $5.536,8$ & $8.280,2$ & $24.547,4$ & $36.066,7$ \\
\hline Sergipe & $4.963,0$ & $4.694,0$ & $11.771,7$ & $17.780,1$ \\
\hline Rio Grande do Norte & $4.921,1$ & $7.022,0$ & $18.473,9$ & $24.700,1$ \\
\hline Alagoas & $3.925,5$ & $5.300,9$ & $13.728,1$ & $19.083,8$ \\
\hline Tocantins & $3.046,9$ & $3.262,5$ & $7.562,6$ & $13.368,4$ \\
\hline Piauí & $2.887,6$ & $4.877,8$ & $12.391,0$ & $17.005,7$ \\
\hline Rondônia & $2.226,5$ & $5.062,4$ & $11.585,6$ & $18.068,8$ \\
\hline Acre & 862,3 & $2.279,2$ & $4.762,1$ & $6.796,6$ \\
\hline Roraima & 654,6 & $2.461,8$ & $4.207,4$ & $5.153,1$ \\
\hline Amapá & 635,1 & $3.182,1$ & $6.040,0$ & $6.899,0$ \\
\hline
\end{tabular}

Fonte: Fundação Seade; Instituto Brasileiro de Geografia e Estatística - IBGE.

(1) Dados sujeitos à revisão.

(2) Inclui o VA da Administração Pública.

Elaboração: PMSP/SMDU/Dipro 
$\mathrm{O}$ valor do Produto Interno Bruto $(\mathrm{PIB})^{17}$ do município de São Paulo é maior do que muitos países, e vem se mantendo estável na participação no PIB nacional desde 2005, conforme o gráfico 3, onde verificamos a tendência estável. Sua participação apresentou aumento nos últimos registros, passando de 11,8\% em 2008 para 12\% em 2009.

Gráfico 3 - Participação do Produto Interno Bruto Brasileiro, 1999 a 2009

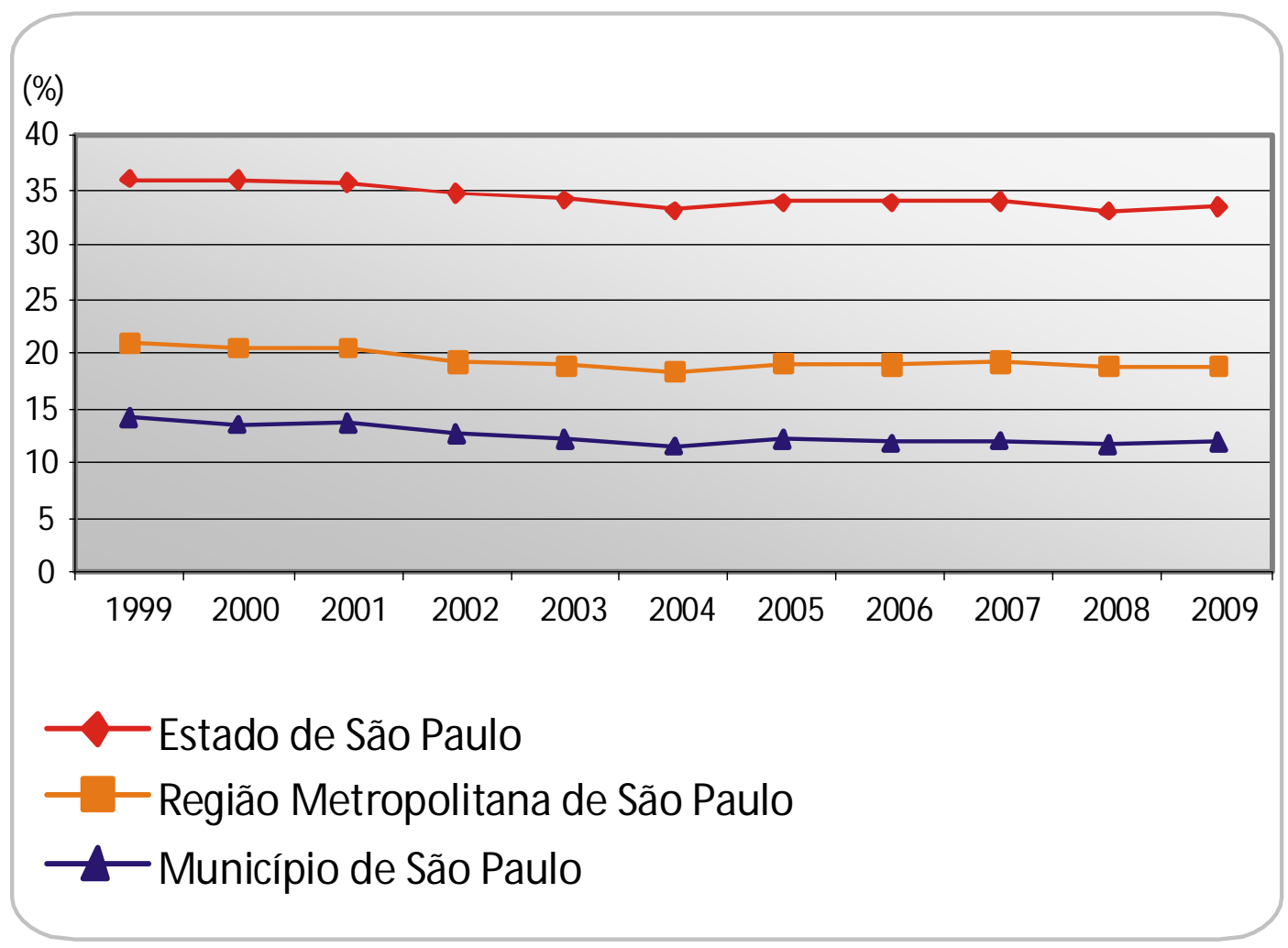

Fonte: Fundação Seade; Instituto Brasileiro de Geografia e Estatística - IBGE.

Elaboração: PMSP/SMDU/Dipro

Assim, São Paulo mostra que, para angariar status de uma cidade global, não é imperativo se desfazer de sua indústria. $\mathrm{O}$ fato é que até os dias atuais a indústria tem importância ímpar para o desenvolvimento e crescimento da cidade e da metrópole, não só por sua participação do PIB, mas também por deter quase $22 \%$ dos postos de trabalho formais da iniciativa privada local ${ }^{18}$, além de ser determinante no dinamismo do setor de serviços prestados às empresas (SÃO PAULO, 2012).

\footnotetext{
${ }^{17}$ Valor total da produção de bens e serviços num país ou território em determinado período de tempo (geralmente um ano)

${ }^{18}$ Ver: Informes Urbanos - Número 4: O crescimento formal do emprego formal na cidade de São Paulo.

Disponível em: http://smdu.prefeitura.sp.gov.br/informes_urbanos/
} 


\section{Distribuição das atividades econômicas}

O debate sobre as estratégias locacionais das empresas, principalmente as grandes empresas, produziram dois consensos: o primeiro diz que elas são seletivas em relação ao lugar onde se instalam, e o segundo afirma que elas transformam ou exigem que esses lugares sejam transformados para melhor servir aos seus interesses. O resultado dessa combinação é a criação de subespaços especializados que demandam de territórios com níveis de fluidez cada vez maiores, ou seja, territórios com alta capacidade de circulação, nos quais passem diferentes tipos de redes para diferentes tipos de fluxos. Essa transformação envolve diretamente os setores privados da sociedade (representados pelas empresas) e pelo poder público (representado pelo Estado). O resultado desse processo é a formação de espaços luminosos, lugares dotados que densidades técnicas e informacionais, espaços que ganham a características de comando em função da normativa que se estabelece pelo poder regulatório tanto das empresas quanto do setor público, diferente dos espaços opacos, não detentores dessas características.

Se pegarmos como parâmetro as empresas de serviços intensivos em conhecimento na cidade de São Paulo, em busca de um esboço de um padrão locacional, é possível observar, a partir dos dados da Pesquisa da Atividade Econômica Paulista - PAEP $2001^{19}$, que predominam os fatores locacionais de natureza mais tradicional, ligados às infraestruturas em geral, mas principalmente de transporte e a proximidade dos mercados consumidores; o fator de dependência dessas empresas com relação a fontes de informação e produção de conhecimento está mais ligado às grandes empresas, porém, mesmo nessas os fatores tradicionais são relevantes (BESSA, 2007).

O debate sobre os serviços nas grandes cidades é polêmico, pois indicaria uma terciarização da economia em detrimento da indústria, seria a passagem do fordismo para o pós-fordismo, como sintetiza Carlos Brandão $(2005)^{20}$. Contudo, consideramos fundamental dizer que não se trata de uma substituição de produtos por serviços, mas sim de um novo modelo tecnológico informacional que rege todo o ciclo produtivo (produção, distribuição,

\footnotetext{
${ }^{19}$ Trabalho elaborado por Vagner de Carvalho Bessa (2007), com dados da PAEP-2001 da Fundação Seade.

${ }^{20}$ Segundo o autor, os trabalhos que defendem a passagem da sociedade industrial para a pós-industrial, utilizando o "viés terciarista", apontando as vantagens ilimitadas desse cenário, indicam uma sociedade pouco conflituosa, ao passo que uma "visão etapista", asseverando a existência de um estágio do capitalismo contemporâneo de dominância terciária, não é nova, mas é conservadora" (BRANDÃO, 2005).
} 
consumo e administração) $)^{21}$. Trata-se da conformação do meio técnico-científicoinformacional de que nos falava Milton Santos (2004), quando a técnica da informação ganha relevância sobre as demais técnicas, permitindo a comunicabilidade entre as diferentes técnicas, sua integração, possibilitando a simultaneidade das ações, acelerando o processo histórico e, assim, possibilitando o processo atual da globalização (SANTOS, 2000 e 2004). O surgimento de novos serviços e o crescimento de atividades especializadas são reflexos das mudanças no período atual, quando a técnica da informação possibilita a fragmentação de setores produtivos e auxiliares das empresas, mas que continuam agindo em complementaridade; dessa maneira, alguns serviços realizados anteriormente na própria indústria ou em qualquer outra empresa hoje são realizados por empresas prestadoras de serviços terceirizadas, que assumem parte das atividades, como jurídico, marketing, serviços de segurança, limpeza, contact center e outros.

Como já destacamos, a indústria é um setor presente e importante para cidade de São Paulo, e sua distribuição está estreitamente relacionada com as redes de circulação, a começar com a rede de trens que, na forma e na medida com que se instalava, criou condições de fluidez necessária à atividade industrial. Com o passar dos anos, a rodovia toma a frente no provimento dessa fluidez e começa a condicionar a localização da indústria. Podemos observar sua distribuição no mapa 8 , destacando as áreas com predominância de indústrias e armazéns, notadamente concentrados nas linhas férreas e grandes vias de circulação. Merece destacar a região sudeste, área do rio Tamanduateí, como primeiro eixo industrial da cidade e que se liga a região do $\mathrm{ABC}^{22}$. Em seguida, observamos às margens do rio Tietê, seguindo para região oeste da cidade, uma segunda concentração em Água Branca, Lapa e Vila Leopoldina, que se estende na direção norte pela Rodovia Anhanguera e, mais destacada ao sul, a área de Santo Amaro e Jurubatuba que até os dias atuais mantém forte presença industrial. Essas áreas sofrem forte pressão na medida em que o valor da terra se eleva. Os atores dessa pressão são por um lado o mercado imobiliário à procura de terrenos para seus projetos residenciais e comerciais, e por outro lado ações do poder público que por vezes procura valorizar essas áreas, favorecendo toda e qualquer atividade menos a que está ali instalada. A visão de requalificar o espaço urbano geralmente segue o vício de acreditar que, para alcançar esse objetivo, é necessário eliminar a indústria em favor dos serviços. Não se

\footnotetext{
${ }^{21}$ Ver MEYER, Regina Maria Prosperi. Atributos da Metrópole Moderna. São Paulo em Perspectiva. n. 14, p. 3$9,2000$.

${ }^{22}$ Conjunto de municípios, a saber: Santo André, São Bernardo do Campo e São Caetano, que se destacam pela forte atividade industrial.
} 
concebe a cidade como um lugar onde é possível e necessária a atividade de produção efetiva. Dar nova função as formas urbanas abandonadas, obsoletas, mudar a imagem de degradação de um lugar, exige a refuncionalização das relações sociais que ali subsistem, processo diferente do praticado hoje com a requalificação urbana, empregada pelos atores hegemônicos da cidade como uma estratégia de intervenção, que tem resultado, de maneira geral, na expulsão de comunidades locais e na substituição de uso do solo urbano (ARANTES, 2000), (SASSEN; ROOST, 2001). Trata-se de retirar aquilo que não serve mais, que prejudica a imagem e o funcionamento do lugar, e trocar pelo novo e moderno.

\section{Mapa 8 - Uso do Solo Predominante - Indústria, 2006}

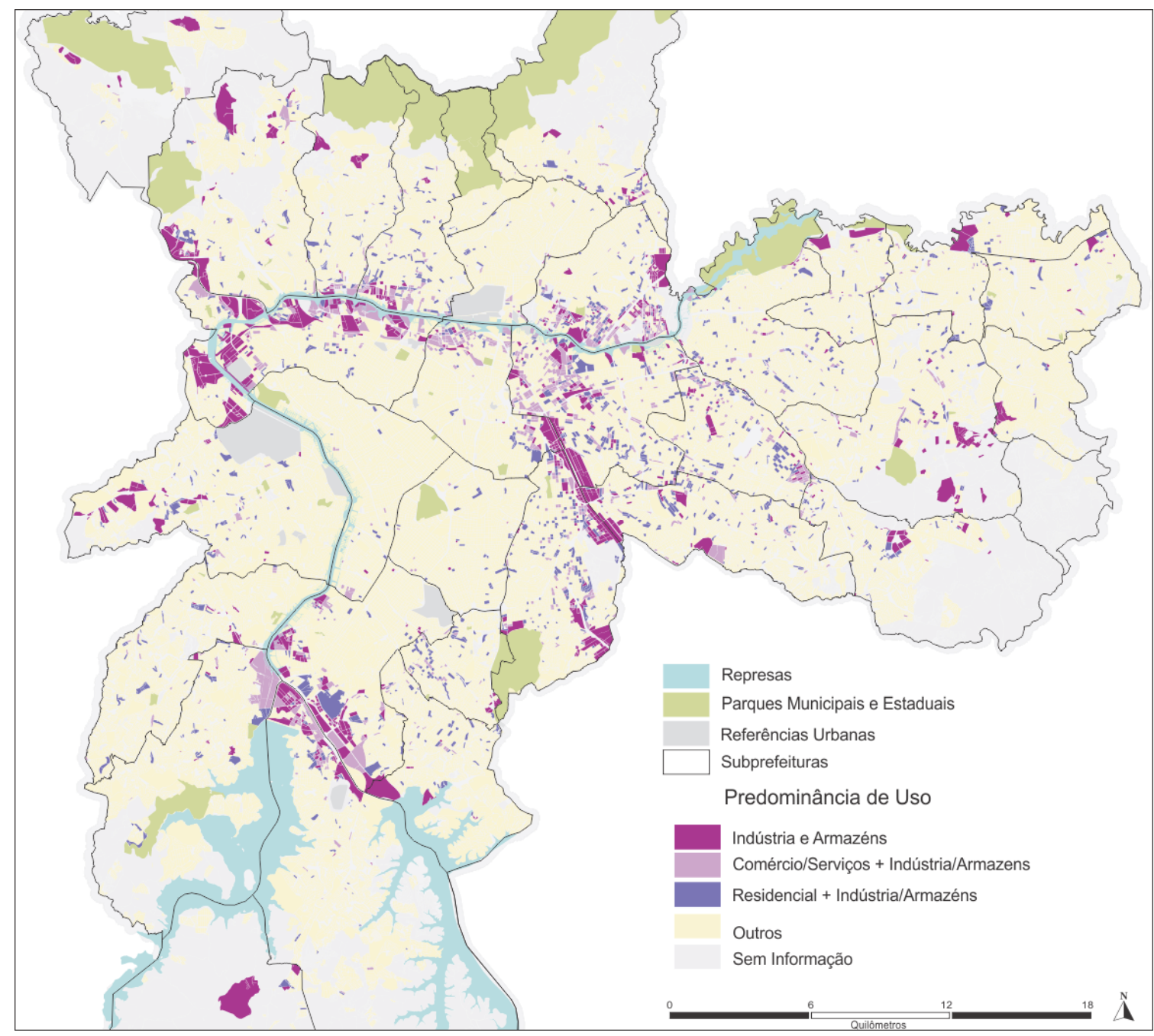

Fonte: Secretaria Municipal de Finanças. Cadastro Territorial Predial de Conservação e Limpeza (TPCL) 
As rodovias, que ligam a cidade com o restante do país e com o mundo, formam hoje a principal rede de circulação utilizada pela indústria. Podemos verificar no mapa seguinte a distribuição da variação de área construída da indústria entre 1991 e $2010^{23}$. As áreas mais tradicionais de localização industrial, entre elas, Tamanduateí, Brás, Lapa, Santo Amaro, Jurubatuba, sofreram forte redução durante o período destacado, apresentando fortes taxas negativas de crescimento da área construída, aqui representada por um índice que vai de -1 a 1, indicado pela coloração dos círculos. Seu tamanho representa a variação em número absoluto de modo que podemos observar a grandeza da variação. Contudo, existem variações positivas, sobretudo na zona leste da cidade e no vetor noroeste, seguindo a Rodovia Anhanguera.

As informações utilizadas para geração do mapa são provenientes do Cadastro Territorial e Predial de Conservação e Limpeza (TPCL), fonte de enorme riqueza de dados sobre uso e ocupação do solo no município, sendo utilizado com frequência por urbanistas e planejadores para análise do espaço urbano. No entanto, cabe ressaltar que alguns cuidados devem ser tomados ao utilizar os dados do TPCL. Tendo em vista que sua natureza é o cadastro imobiliário da prefeitura de São Paulo, com base fiscal. Logo, o alcance da informação em todo o conjunto da cidade é prejudicado em consonância com aquilo que é fiscal e aquilo que é real. Nem tudo que existe está nos cadastros fiscais. A qualidade da informação é maior em área de urbanização consolidada da cidade. Para um conjunto de 12 distritos, os dados devem ser utilizados e analisados com precaução, a saber: ao sul, Grajaú, Parelheiros e Marsilac; à leste, São Rafael, Iguatemi, Parque do Carmo, José Bonifácio e Cidade Tiradentes; à noroeste, Anhanguera, Perus e Jaraguá; ao norte, Tremembé. Além da variação de qualidade na cobertura da informação, existem algumas inconsistências pontuais de um ano para o outro em algumas quadras. Isso vai depender da classificação utilizada. (SÃO PAULO (cidade), 2006). Ainda assim, mesmo com sua limitação, não podemos abrir mão do uso dessa valiosa informação. Conhecer seus limites é preciso para melhor interpretar seus resultados.

\footnotetext{
${ }^{23}$ Para saber mais sobre a metodologia relacionada ao uso predominante do solo em relação à área construída, ver: SÃO PAULO (cidade). Secretaria Municipal do Planejamento. Evolução do uso do solo nos anos 90 . São Paulo, Sempla, 2000, p.43.
} 


\section{Mapa 9 - Variação da área construída da indústria, 1991/2010}

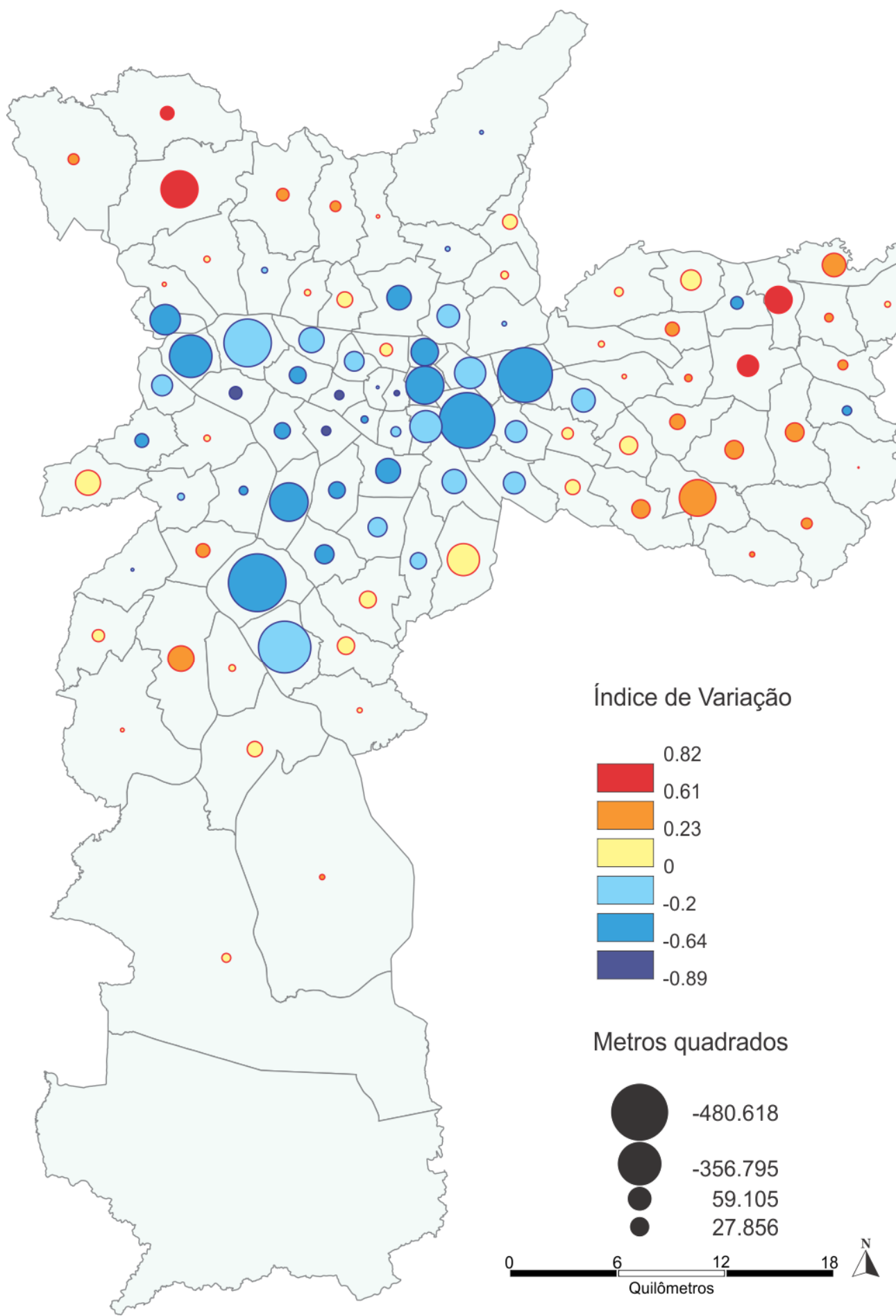

Fonte: Secretaria Municipal de Finanças. Cadastro Territorial Predial de Conservação e Limpeza (TPCL).

Base cartográfica: Secretaria Municipal de Desenvolvimento Urbano - SMDU/Dipro Elaboração: André de Freitas Gonçalves 
Ao verificar quais distritos municipais tiveram variação negativa no acréscimo de área construída $(\mathrm{AC})$ e acréscimo da área de terreno (AT), construímos uma tipologia na qual a categoria 1 é quando o distrito tem variação negativa tanto na $\mathrm{AC}$ quanto na $\mathrm{AT}$, a categoria 2 são os distritos que possuem variação positiva na AC e negativa na AT e por fim a categoria 3 são distritos com variação positiva na AC e na AT. Assim obtivemos o mapa seguinte, mostrando de forma clara a grande área de variação negativa e por outro lado a positiva, identificando distritos onde o incremento de área construída na indústria foi acompanhado por perda de área de terreno industrial. A reestruturação produtiva é sempre uma reestruturação espacial, tanto em suas funções quanto em suas formas.

\section{Mapa 10 - Tipologia dos distritos segundo variação da área construída e do terreno da indústria -1991/2010}

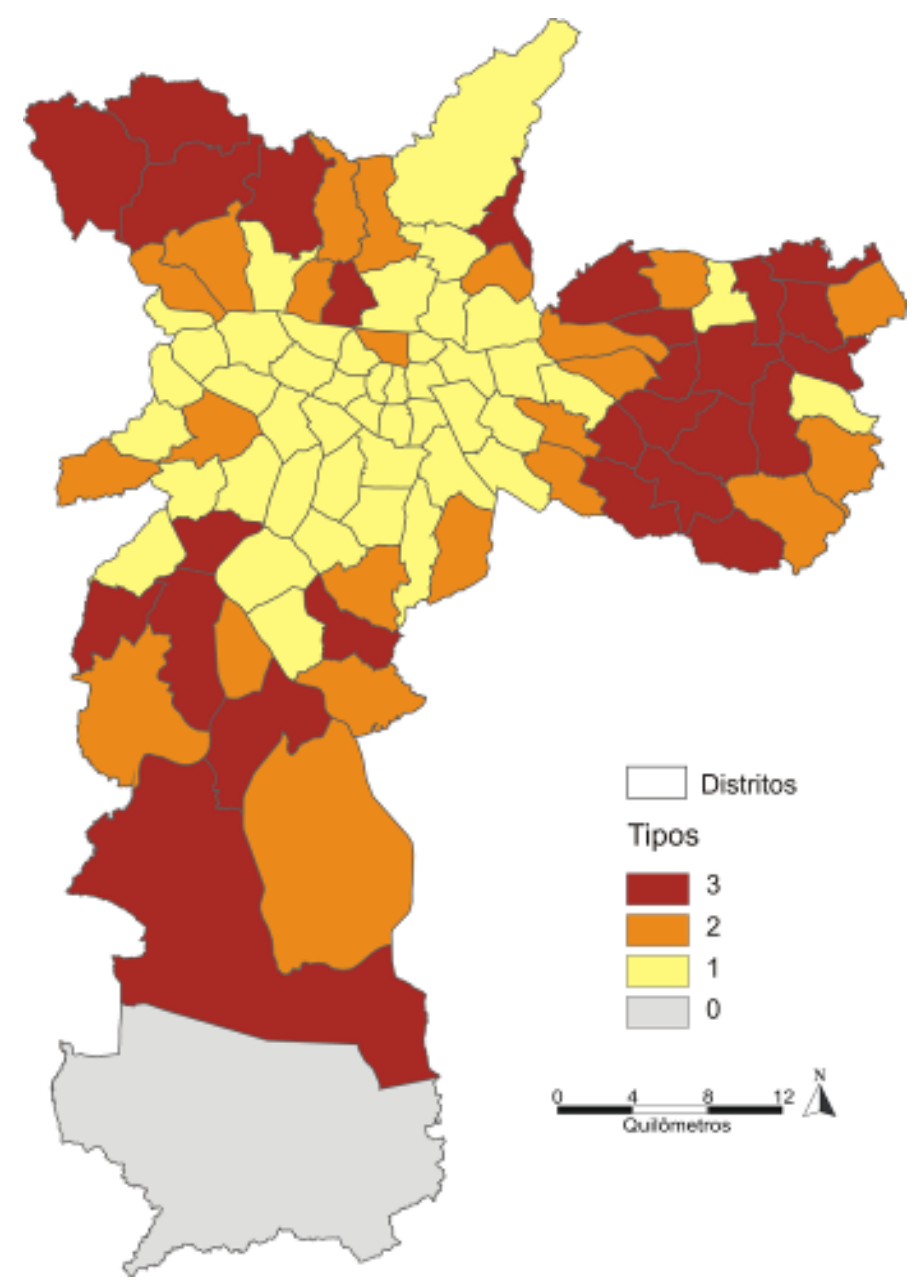

Fonte: Secretaria Municipal de Finanças. Cadastro Territorial Predial de Conservação e Limpeza (TPCL).

Base cartográfica: Secretaria Municipal de Desenvolvimento Urbano - SMDU/Dipro Elaboração: André de Freitas Gonçalves 
Considerando a variável de emprego formal levantada pelo Ministério do Trabalho e Emprego por meio da Relação Anual de Informações Sociais (Rais) e o Cadastro Geral de Empregados e Desempregados (CAGED) ${ }^{24}$, identificamos o movimento da concentração da atividade industrial no período de 1996 até 2006. No mapa seguinte, observamos a variação do emprego na indústria que mostra as áreas que perderam e que ganharam empregos entre os anos de 1996 e 2006. Fica claro que áreas tradicionais de localização da indústria perdem empregos, enquanto áreas periféricas apresentam algum ganho. Entre as áreas tradicionais, estão o eixo Marginal do Tietê e Marginal do Pinheiros que perdeu 68,6 mil empregos, Centro e Eixo Rio Tamanduateí que perdeu 52,2 mil empregos e a área de Santo Amaro e Jurubatuba com perda de 51,2 mil empregos. As áreas em destaque que ganharam empregos são: Eixo Jacu-Pêssego e São Mateus com 5 mil empregos, Raposo Tavares 2 mil, Região de Pirituba, Freguesia do Ó e São Domingos com 3,3 mil empregos e Luz e Bom Retiro com 1,3 mil empregos. Mesmo com esse ganho de empregos e de área construída, não houve reconfiguração da distribuição extremamente concentrada da indústria da capital.

Os condicionantes que restringem a indústria no seu arco mais antigo são relevantes para todas as empresas, independentemente de seu porte, o que contraria a hipótese de que há uma reconversão industrial da cidade baseada em uma dualidade econômica e territorial: enquanto as empresas industriais transnacionais se modernizam e contam com um aporte crescente de tecnologia, buscando vantagens de aglomeração nos espaços adjacentes ao município, as pequenas unidades, servindo-se de relações de trabalho precárias e informais, desvinculam-se das médias e grandes empresas fixadas nos eixos ferroviários e rodoviários mais antigos e se dispersam pelo território, constituindo na capital uma "nova territorialização da produção" (ROLNIK \& FRUGOLI, 2001). Ainda que seja verdade que as plantas menores dispõem de maior possibilidade de mobilidade espacial (...), mapas sobre a distribuição do emprego industrial segundo porte de empresa na capital mostram que as micro, pequenas e médias indústrias apresentam alto nível de aglomeração nos eixos tradicionais da cidade (BESSA et al, 2012, p. 143).

\footnotetext{
${ }^{24}$ Trabalho publicado em: COMIN, Alvaro et al.(Org). Metamorfoses paulistanas: atlas geoeconômico da cidade. São Paulo. Coedição: SMDU/CEBRAP/Imprensa Oficial do Estado de São Paulo/Editora UNESP, 2012. Tem origem na pesquisa Atlas geoeconômico e mutações territoriais na cidade de São Paulo, encomendada pela Secretaria Municipal de Planejamento (SEMPLA) ao Centro Brasileiro de Análise e Planejamento (CEBRAP).
} 


\section{Mapa 11 - Variação do emprego no setor da indústria, 1996/2006}

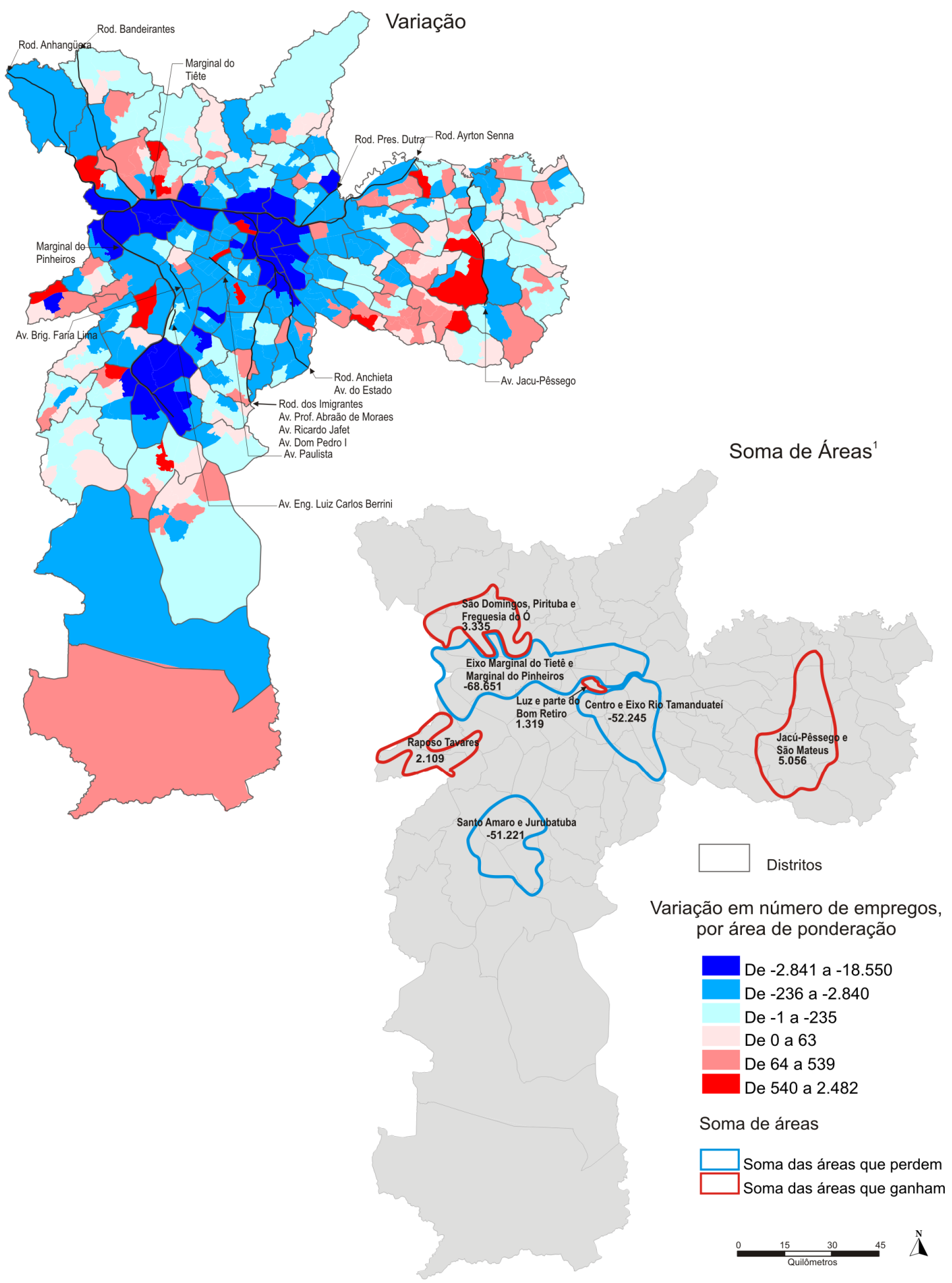

Fonte: Ministério do Trabalho e Emprego. Relação Anual de Informações Sociais (Rais);

Cadastro Geral de Empregados e Desempregados - CAGED

Base cartográfica: Secretaria Municipal de Planejamento - Sempla/Dipro

(1) É a soma das áreas que ganham ou perdem emprego.

Elaboração: Centro Brasileiro de Análise e Planejamento - Cebrap, 2008 


\section{Mapa 12 - Distribuição do emprego no setor da indústria}

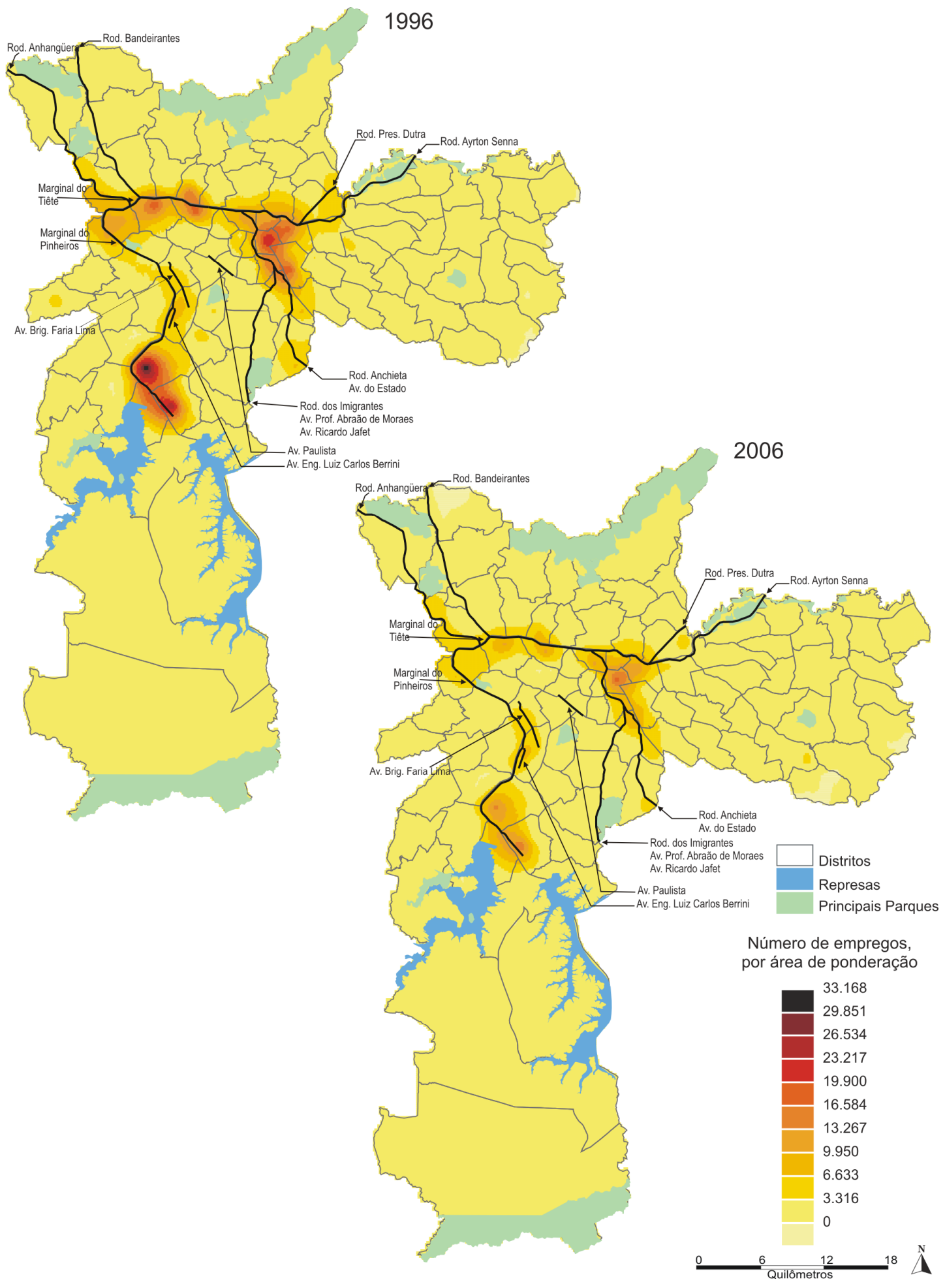

Fonte: Ministério do Trabalho e Emprego. Relação Anual de Informações Sociais (Rais);

Cadastro Geral de Empregados e Desempregados - CAGED

Base cartográfica: Secretaria Municipal de Planejamento - Sempla/Dipro

Elaboração: Centro Brasileiro de Análise e Planejamento - Cebrap, 2008 
Ao analisarmos a distribuição da atividade de serviços, entre 1996 e 2006, observamos uma forte concentração de emprego na área central da cidade e na direção do vetor Sudoeste, seguindo da Avenida Paulista em direção à Avenida Brigadeiro Faria Lima, Avenida Eng. Luiz Carlos Berrini e Marginal do Rio Pinheiros em direção a Santo Amaro. Entre um ano e outro, podemos notar que os níveis de concentração se elevaram, apesar de a mancha ter ganhado novas áreas nas regiões Oeste e Sul da cidade (Mapa 13).

A expansão de atividades de serviço e do fluxo de investimentos privados do setor imobiliário em direção sul da cidade, passando pela Avenida Verbo Divino ou seguindo a Marginal do Rio Pinheiros em direção a Santo Amaro, alcançando o Centro Empresarial de São Paulo junto à ponte João Dias e seguindo em direção a áreas de antigas indústrias, é uma realidade para aqueles que circulam na cidade ${ }^{25}$. Outro ponto importante de novas concentrações de atividade terciária é a região da Barra funda e Lapa, com reconversão urbana e criação de espaços com novas funções, antigamente ocupada pela indústria e agora com atividades de serviços, com seu Centro Empresarial Água Branca e o surgimento de novas empresas, com destaque a empresas de contact center (GONÇALVES, 2008). Um fato curioso sobre a ação imobiliária na região é a declaração do arquiteto Carlos Bratke, responsável pelos primeiros edifícios na Avenida Berrini e que soma mais de 60 edifícios comerciais na mesma avenida, contando que chegou a estudar a Barra Funda, mas escolheu a região da Marginal do rio Pinheiros pelo baixo custo dos terrenos, por ser próxima ao Morumbi, pela topografia plana e pelos projetos viários que seriam construídos ${ }^{26}$.

Fica claro nos mapas seguintes, a dinâmica territorial do emprego na cidade de São Paulo, mostrando que não se trata de um processo linear onde o emprego migra integralmente de um lugar para o outro e reforça a argumentação anterior ao mostrar novas regiões "ganhadoras" que até então não tinham o merecido destaque. Na região do centro histórico e seu entorno, houve um ganho de 88,9 mil empregos em 10 anos. A exceção fica por conta da área da Santa Ifigênia que perdeu 14,5 mil empregos. Nas proximidades da área central, ainda temos uma área que pega a Consolação e o Paraíso, que obteve ganho de 65,5 mil postos de trabalho, cercada por áreas que perderam empregos como Higienópolis e Consolação (-14.507), Bela Vista (-11.404) e Trianon (-16.801). Ao oeste da cidade,

\footnotetext{
${ }^{25}$ Ver mais em: PADUA, Rafael Faleiros de. Implicações socioespaciais da desindustrialização e da reestruturação do espaço em um fragmento da metrópole de São Paulo. São Paulo, FFLCH, 2008. Disponível em: http://www.fflch.usp.br/dg/gesp/baixar/livro_rafael.pdf

${ }^{26}$ Fonte: Folha de São Paulo, 30/11/2003, reproduzido no site: <http://www.sindico.com.br > Acesso em: $04 / 12 / 2007$
} 
observamos a região da Barra Funda e um trecho do Alto da Lapa, apresentando um ganho de postos de trabalho significativo em torno de 52,9 mil. Em suas proximidades, temos duas áreas com valores negativos: a Lapa com -7,7 mil postos de trabalho e Alto de Pinheiros com -13,2 mil postos de trabalho. A região compreendida como Marginal do Pinheiros engloba áreas de Avenida Brigadeiro Faria Lima, Avenida Luiz Carlos Berrini, Avenida Verbo Divino, Santo Amaro e toda a parte de bairros nobres como o Morumbi e parte do Butantã. É dividida em duas partes: Leste a parte mais consolidada com forte incremento de postos de trabalho - 126,2 mil empregos - e parte Oeste, que compreende fração dos bairros principalmente residenciais com ganho bem menor em torno de 27,9 mil postos de trabalho.

O dinamismo da área decorre tanto do crescimento de novas atividades como do reagrupamento de segmentos com requisitos locacionais específicos dentro desse tecido. Apesar de compartilhar lógicas diferenciadas, no cômputo geral a estrutura econômica do centro expandido aparenta um grau de organização e complementaridade maior que as perspectivas que enfatizam a concorrência entre as áreas permitem observar (BESSA et al, 2012, p. 132).

Fica clara a relevância do vetor sudoeste da cidade, não somente nas áreas da Avenida Brigadeiro Faria Lima e Avenida Luiz Carlos Berrini, mas também na Marginal do Pinheiros e Avenida Verbo Divino em direção ao sul da cidade. É possível observar que essa região se expande fortemente, ao mesmo tempo em que também é evidente a importante participação de novas áreas de reconversão urbana aqui representada principalmente pela região da Barra Funda. Como perspectiva e mudança, temos as regiões da Vila Leopoldina, Vila Sonia e Jacu-Pêssego, essa última na Zona Leste da cidade, exemplos de áreas onde o poder público age fortemente para desenvolver um dinamismo econômico e social a fim de descentralizar as atividades econômicas e ao mesmo tempo criar novas oportunidades de negócio na cidade. Essa iniciativa é realizada em praticamente todos os casos com parceria público-privada (PPP) em diferentes tipos de projetos, seja pela instalação de Operação Urbana Consorciada, construção de linhas de metrô, equipamentos públicos, criação de polos econômicos, institucionais, tecnológicos e de equipamentos e investimentos que perseguem esse objetivo. Veremos isso com detalhes no próximo capítulo. 


\section{Mapa 13 - Distribuição do emprego no setor de serviços}

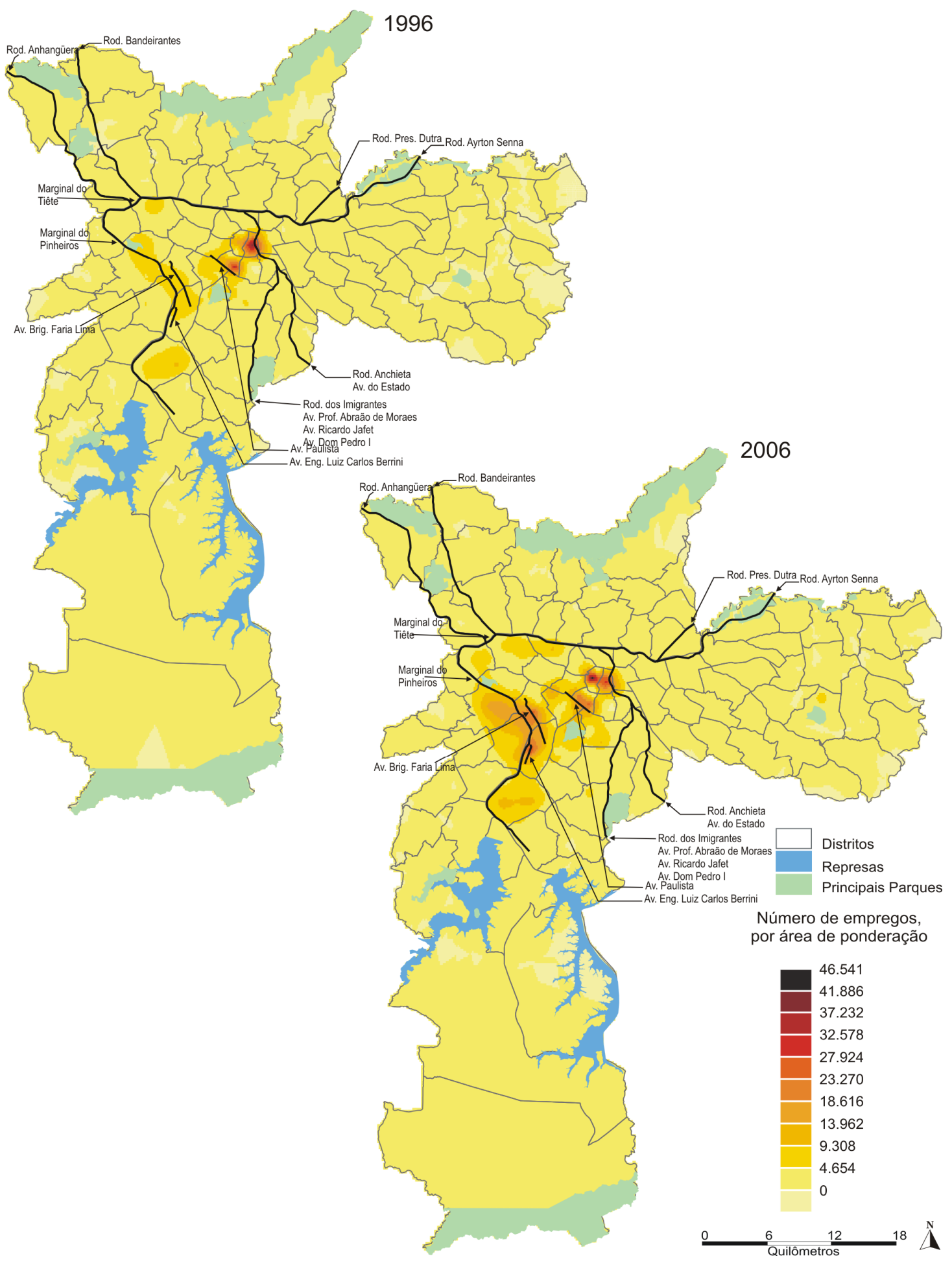

Fonte: Ministério do Trabalho e Emprego. Relação Anual de Informações Sociais (Rais);

Cadastro Geral de Empregados e Desempregados - CAGED.

Base cartográfica: Secretaria Municipal de Planejamento - Sempla/Dipro

Elaboração: Centro Brasileiro de Análise e Planejamento - Cebrap, 2008 


\section{Mapa 14 - Variação do emprego no setor dos serviços, 1996/2006}

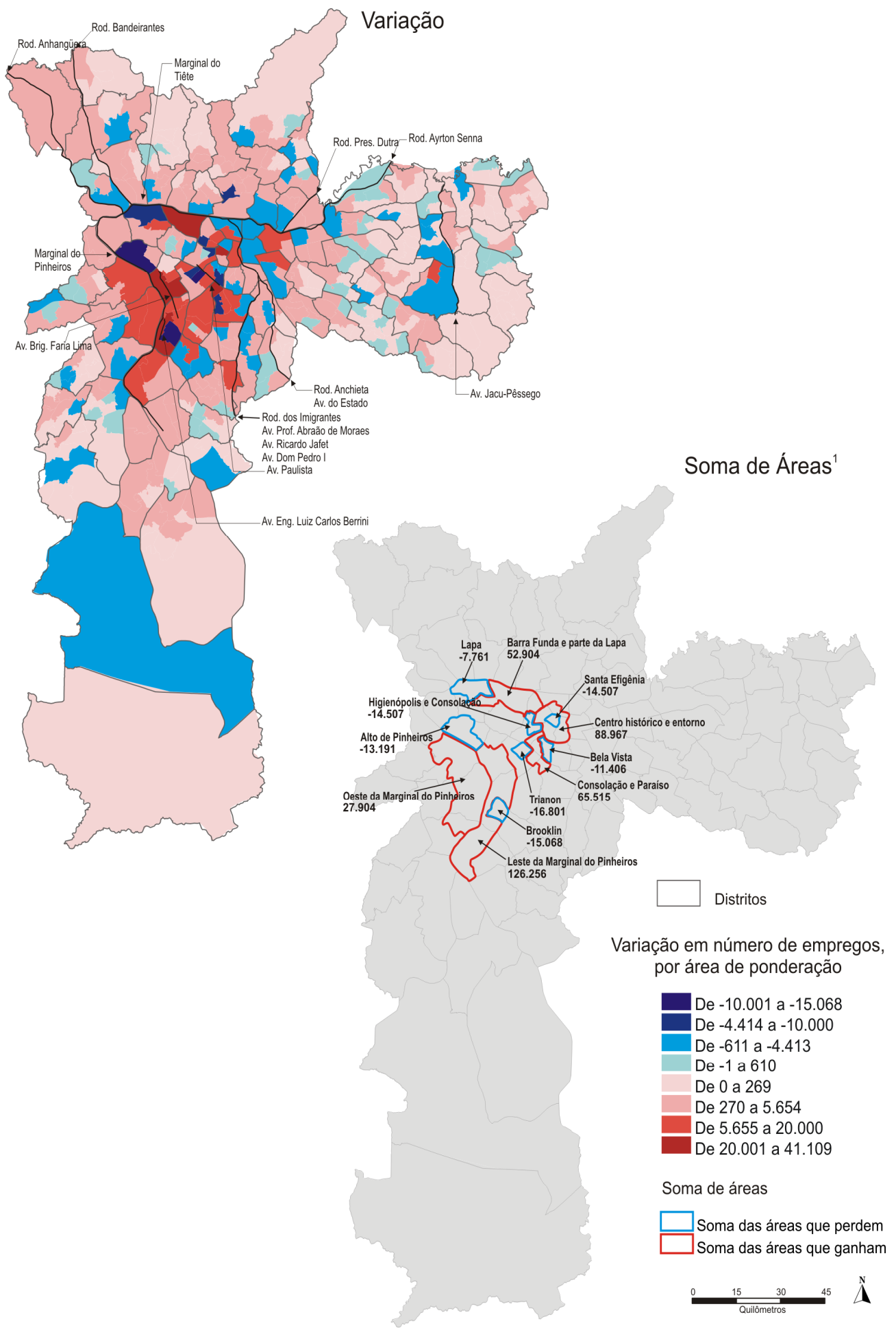

Fonte: Ministério do Trabalho e Emprego. Relação Anual de Informações Sociais (Rais);

Cadastro Geral de Empregados e Desempregados - CAGED.

Base cartográfica: Secretaria Municipal de Planejamento - Sempla/Dipro

(1) É a soma das áreas que ganham ou perdem emprego.

Elaboração: Centro Brasileiro de Análise e Planejamento - Cebrap, 2008 
Importante destacar o forte dinamismo econômico da área em destaque, que podemos chamar de Complexo Corporativo da Metrópole, "conjunto de sedes das grandes empresas de todos os setores da economia e dos seus serviços correlatos" (CORDEIRO, 1993). Delimitaremos com maior precisão essa área posteriormente, contudo aqui basta dizer que é ali que o comando das atividades econômicas é exercido mais fortemente e em uma dimensão geográfica que sobressalta a cidade e a metrópole. Trata-se de um conjunto de mando nacional e internacional.

Essa formação de conglomerado de empresas e sedes de empresas nas áreas relacionadas tem forte ligação ao um conjunto novo de negócios de novos setores de serviços que se somam aos setores industriais que permaneceram na cidade. $O$ crescimento significativo das empresas prestadoras de serviços principalmente para outras empresas, assim como o surgimento de novos serviços especializados tem chamado a atenção de muitos estudiosos de diferentes áreas do conhecimento. Essas empresas, prestadores de serviços, são chamadas de diferentes maneiras: empresas de serviço avançado, moderno ou intensivo em informação e conhecimento. Para cada denominação, existem algumas diferenças, ora um grupo de empresas entra em uma subclassificação, ora em outra. Por vezes. um grupo de empresa pode ser considerado como prestadoras de serviços modernos, mas pode contar com um trabalho pouco intensivo em tecnologia e conhecimento e ainda assim olhar para a estrutura produtiva da cidade por meio da análise de intensidade tecnológica, de informação e de conhecimento. Parece ser essa uma boa perspectiva para superar o obstáculo das tradicionais separações, principalmente relacionadas aos setores industriais e de serviços (COMIN, 2012). Portanto, observamos que a estrutura produtiva da cidade de São Paulo é imensamente diversificada e especializada. Apresenta atividades econômicas em praticamente todas as cadeias produtivas, um setor de serviços dinâmico e diversificado que abrange os mais modernos e especializados serviços, bem como uma indústria ativa e importante. Isso evidencia a força e potencial competitivo da cidade (FREIRE, ABDAL, BESSA, 2012).

Em sua particularidade em relação a grandes metrópoles globais, tem uma indústria ativa e ainda concentrada, sobretudo pelo comando de suas atividades, fortemente concentrada na área entre os rios Tietê e Pinheiros. 


\section{Modelo espacial da economia}

No já referido projeto que se tornou livro, Metamorfoses paulistanas organizado por Álvaro Comin et al. (2012), realizou-se um trabalho de modelização gráfica para representar a dinâmica da atividade produtiva da cidade, assinado por Hervé Théry $(2012)^{27}$. Esse trabalho é muito importante para nós, pois aponta caminhos a serem seguidos a fim de construir um modelo gráfico especificamente para cidade de São Paulo. Contudo, é importante salientar que o autor limita o resultado à análise da estrutura produtiva da cidade $\mathrm{e}$ não mostra um modelo gráfico mais amplo que aqui procuramos desenvolver. Nele o autor apresenta todo o procedimento para construção de um modelo gráfico da distribuição e incidência de atividade econômica a partir da análise das cartografias produzidas para outros artigos do próprio livro.

De início, o autor procura identificar no território pontos de referência para construção inicial do modelo e recorre à distinção de centro (s) e periferia (s), ressaltando o contraste do centro expandido da cidade com suas outras regiões. Na figura 4, podemos observar a identificação de pontos de referência e delimitação do centro expandido por meio de figuras geométricas. Uma vez que o essencial da análise são as estruturas principais que formam o espaço, observamos que existem generalizações na conformidade do desenho, eliminando detalhes de localização. Podemos observar a indicação de parques e áreas verdes muito significativos nos extremos norte e sul da cidade, áreas pouco povoadas, sobretudo no extremo sul. Grandes áreas ocupadas pelas duas represas contidas na cidade, Guarapiranga e Billings. As linhas em vermelho representam o centro expandido da cidade, e alguns dos principais eixos de circulação, as marginais do Tietê e Pinheiros, a Avenida do Estado, Rodovias Bandeirantes e Anhanguera. Esse é o mapa de fundo onde será apresentado o resultado da análise espacial da estrutura produtiva.

Para melhor representar os setores econômicos, foi realizada uma análise segmentada por níveis de intensidade tecnológica e de conhecimento, a partir do trabalho de Freire, Abdal e Bessa (2012) e de Bessa et al. (2012), podendo assim melhor delimitar as figuras que representaram cada setor.

\footnotetext{
${ }^{27}$ Trabalho publicado em: COMIN, Alvaro. et al.(Org). Metamorfoses paulistanas: atlas geoeconômico da cidade. São Paulo. Coedição: SMDU/CEBRAP/Imprensa Oficial do Estado de São Paulo/Editora UNESP, 2012. Tem origem na pesquisa Atlas geoeconômico e mutações territoriais na cidade de São Paulo, encomendada pela Secretaria Municipal de Planejamento (SEMPLA) ao Centro Brasileiro de Análise e Planejamento (CEBRAP).
} 
Figura 4 - Pontos de referência

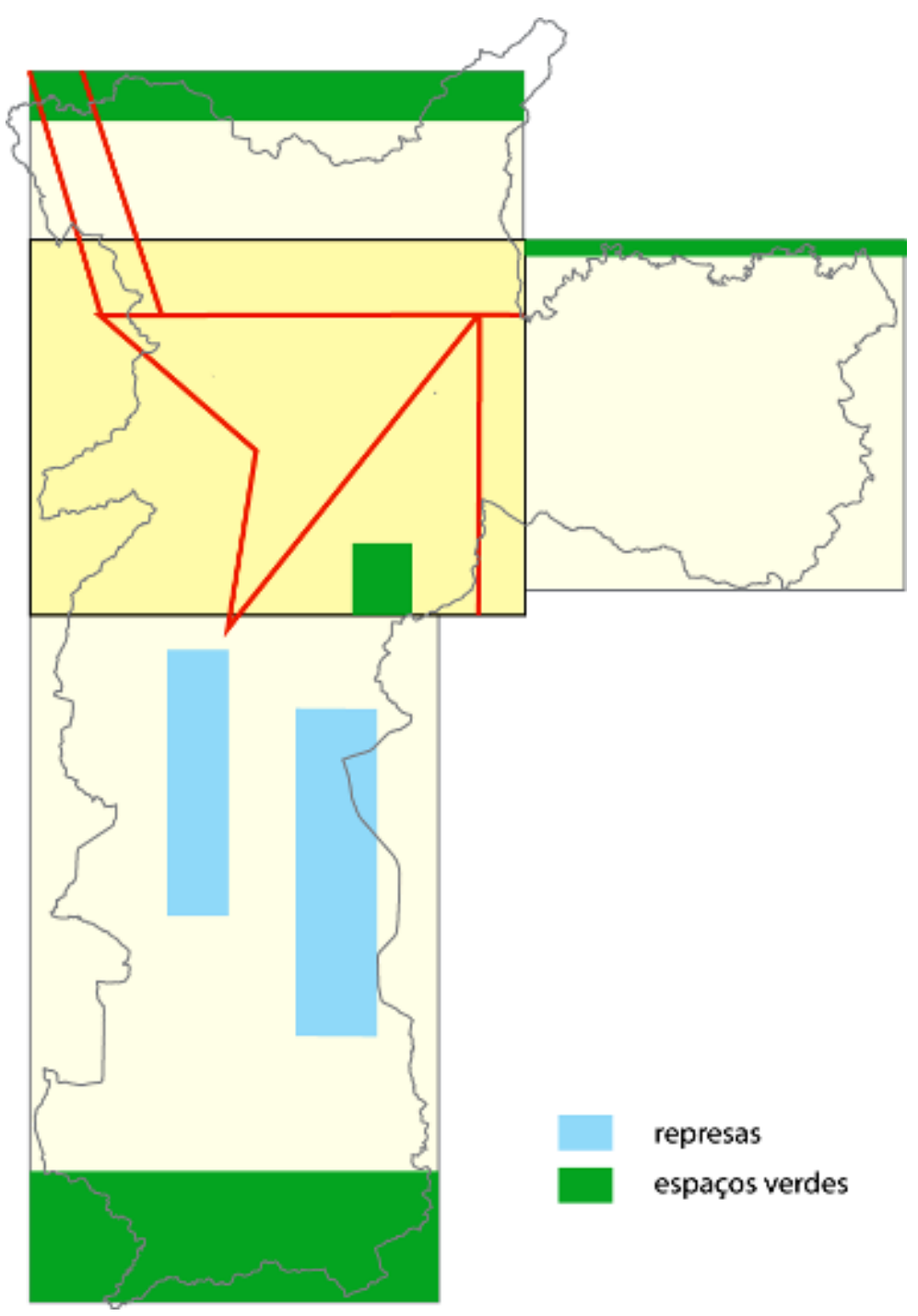

Fonte: THÉRY, Hervé. Modelos gráficos da competitividade paulista. In: COMIN, Alvaro et al.(Org). Metamorfoses paulistanas: atlas geoeconômico da cidade. São Paulo. Coedição:

SMDU/CEBRAP/Imprensa Oficial do Estado de São Paulo/Editora UNESP, 2012.

Na figura seguinte, estão representados o setor da indústria e o setor de serviços, o primeiro dividido em alta, baixa, média-baixa e média-alta intensidade tecnológica e o segundo dividido em serviços intensivos em conhecimento (SIC) tecnológicos, profissionais, financeiros, sociais e mídia ${ }^{28}$. Ambos têm na legenda a diferenciação das figuras entre forte intensidade e menor intensidade. Destacado à esquerda do quadro, para cada conjunto temos a síntese apontando por meio das figuras a configuração para cada setor econômico.

\footnotetext{
${ }^{28}$ Sobre essa classificação ver: FREIRE, C. T.; ABDAL, A.; BESSA, V. Conhecimento e tecnologia: atividades industriais e de serviços para uma São Paulo competitiva. In COMIN, Alvaro et al.(Org). Metamorfoses paulistanas: atlas geoeconômico da cidade. São Paulo. Coedição: SMDU/CEBRAP/Imprensa Oficial do Estado de São Paulo/Editora UNESP, 2012.
} 
Figura 5 - Localizações específicas

Cf. Indústria e mídia: acentuar essas palavras no gráfico abaixo

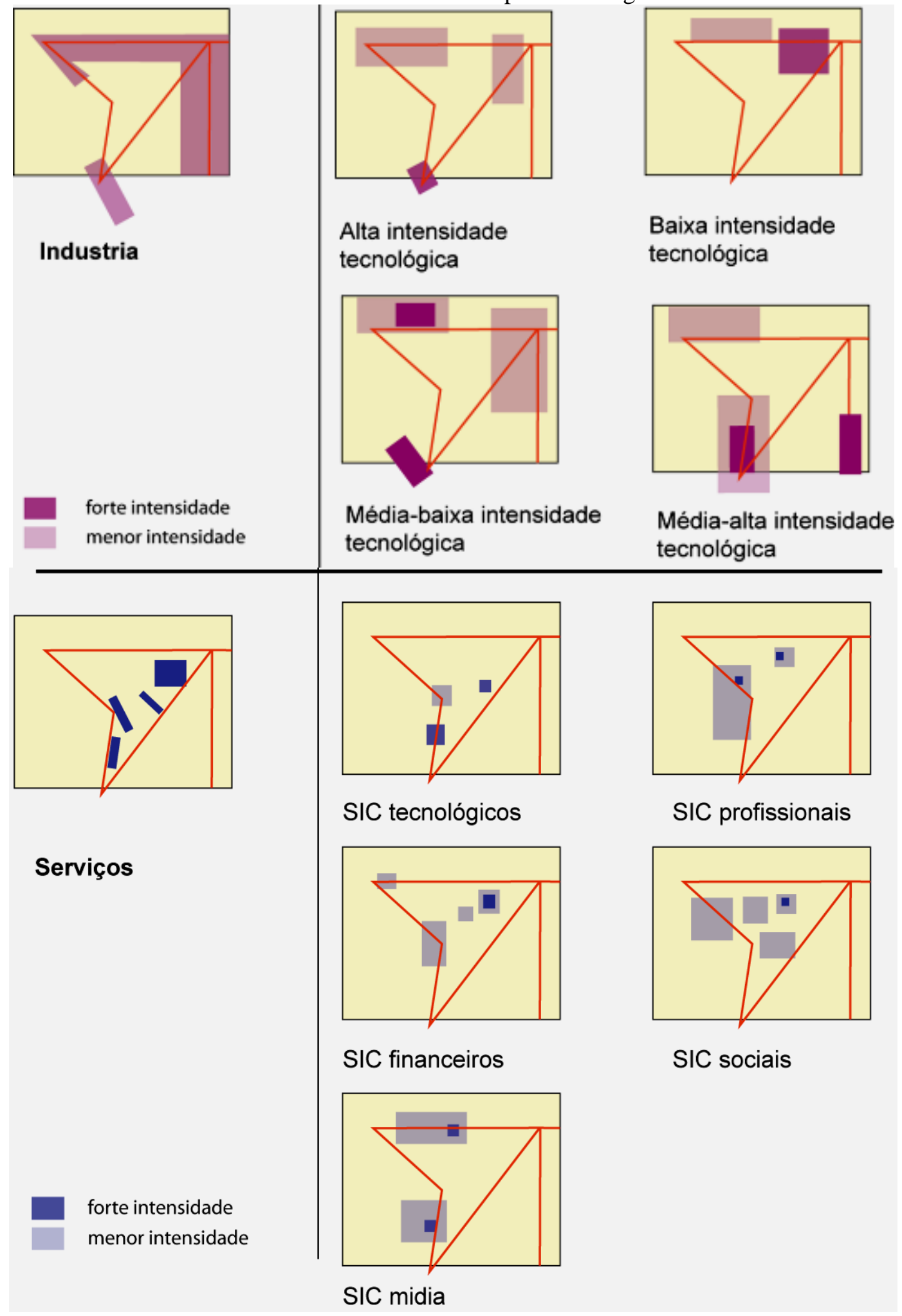

Fonte: THÉRY, Hervé. Modelos gráficos da competitividade paulista. In: COMIN, Alvaro et al.(Org). Metamorfoses paulistanas: atlas geoeconômico da cidade. São Paulo. Coedição:

SMDU/CEBRAP/Imprensa Oficial do Estado de São Paulo/Editora UNESP, 2012. 
Ao observar as representações do setor industrial, notamos que os padrões de distribuição não se repetem entre os níveis de intensidade tecnológica, contudo estão restritos ao arco formado pelo eixo do Tamanduateí, Marginal do Tietê e Pinheiros, e mais isolado Santo Amaro ao sul da cidade. No setor de serviços, as configurações de zonas são bem variadas, porém, isso reforça as já conhecidas centralidades como o centro histórico, região das Avenida Paulista, Avenida Brigadeiro Faria Lima e Avenida Engenheiro Luiz Carlos Berrini. A concentração das atividades de serviços em determinados pontos da cidade é um fato que, à revelia de alguns estudos, dificilmente se transforma radicalmente e de maneira acelerada. Mesmo o centro histórico que, para alguns não supre mais as necessidades de atividades modernas, continua com forte influência na dinâmica econômica da cidade. As atividades de serviços tendem a se fixar próximas aos seus pares. Esse e outros fatores de localização resultam em um cenário territorial extremamente concentrado em relação à distribuição da atividade econômica. Poderíamos:

“... recorrer à linguagem da economia e falar de clusters, mas, basicamente, trata-se apenas do hábito milenar de agrupar-se entre especialistas da mesma atividade para se beneficiar plenamente dos efeitos de vizinhança. Entre outros requisitos locacionais das atividades produtivas, essa configuração, que mostrou a sua eficácia a longo prazo e ainda funciona em alguns dos lugares comerciais mais ativos do planeta, parece merecer toda a atenção dos poderes públicos (THÉRY, 2012, p. 179).

Temos a configuração das zonas industriais e de serviços localizadas dentro e ao redor do centro expandido da cidade, agora nos falta o setor de comércio. Na figura seguinte, podemos observar a representação na sua forma acabada, com os três setores, incluindo o comércio representado com uma superfície homogênea de cor laranja que preenche o centro expandido, isso em função de sua distribuição ser a menos definida e destacada, que se distribui de maneira relativamente homogênea. Os serviços são pontos isolados, que representam os centros de negócio já determinados anteriormente e orientados do centro ao sudoeste. Assim temos: o centro histórico, a Avenida Paulista, a Avenida Brigadeiro Faria Lima e a Avenida Engenheiro Luiz Carlos Berrini (THÉRY, 2012). 


\section{Figura 6 - Três setores e quatro áreas estratégicas}

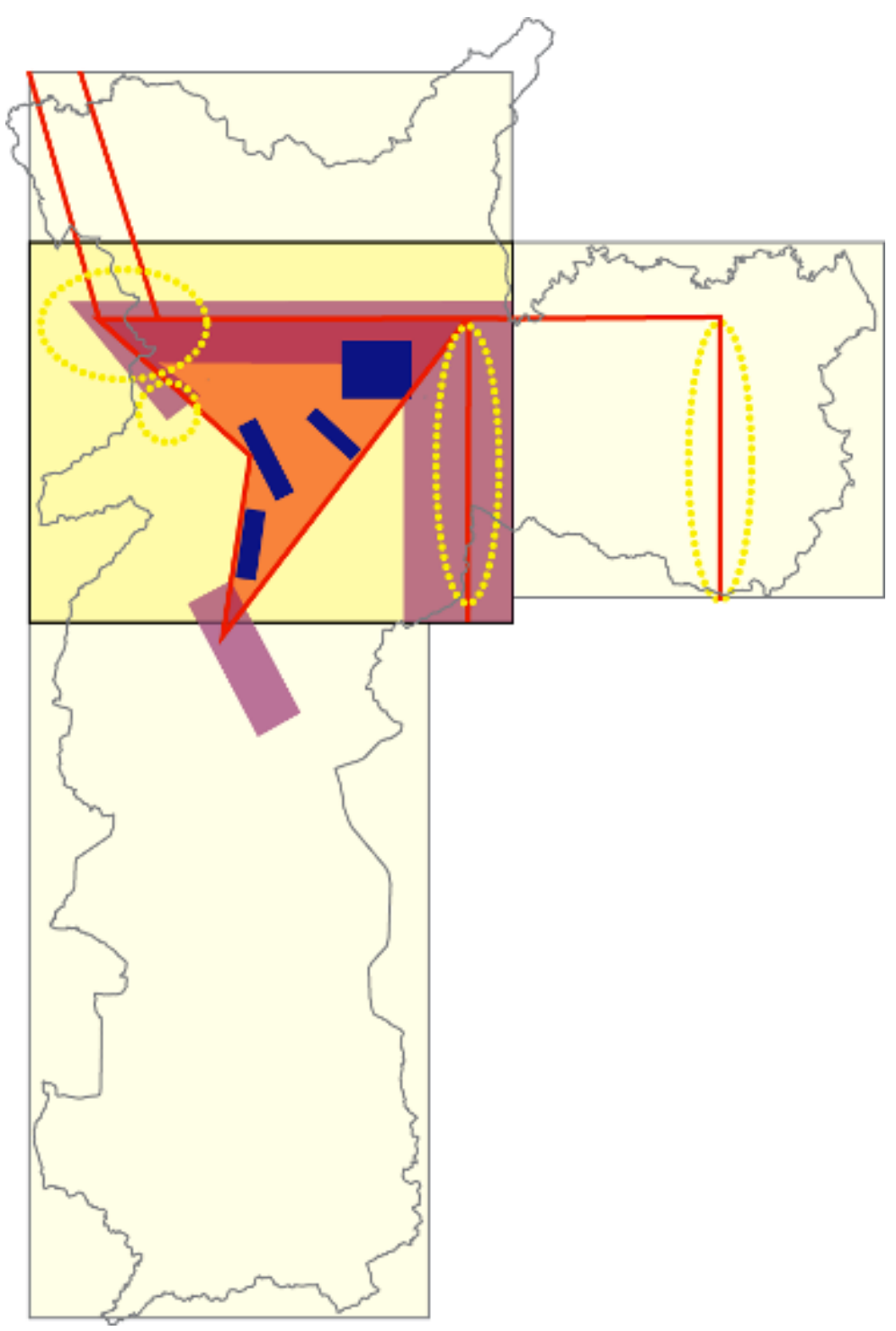

Fonte: THÉRY, Hervé. Modelos gráficos da competitividade paulista. In: COMIN, Alvaro et al.(Org). Metamorfoses paulistanas: atlas geoeconômico da cidade. São Paulo. Coedição: SMDU/CEBRAP/Imprensa Oficial do Estado de São Paulo/Editora UNESP, 2012.

Com essa representação simplificada das estruturas produtivas espacialmente determinadas, é possível perceber as tendências principais de cada setor, assim como ao reunilos em uma só figura "indicar as zonas onde um ou outro dos três setores é dominante e onde funcionam juntos, dois a dois ou os três simultaneamente" (THÉRY, 2012, p. 176). Em destaque, as áreas estratégicas selecionadas no projeto e livro mencionado, o que evidencia mais uma qualidade do método aqui utilizado que é a possibilidade de identificar as fragilidades e potencialidades do território. Especificamente aqui, o eixo da Jacu-Pêssego é tido como um contraponto possível à concentração econômica da cidade. 


\section{Dinâmicas urbanas}

Na dinâmica territorial da cidade de São Paulo, de inquestionável complexidade, atuam diferentes atores e processos, onde a questão de escala levantada por Neil Smith (1988, 2007) se torna um fundamental instrumento de análise quando percebemos determinações mais gerais e especificidades locais, agindo em complementaridade, contudo de formas diferentes.

As organizações locais desempenham uma importante função em relação às intervenções na estrutura urbana, pois conseguem aglutinar força e ter alcance ao poder público local, assim como, dependendo do tipo de organização, ter acesso à mídia local a fim de fortalecer seu discurso, esse que tem por objetivo defender seus próprios interesses, mesmo quando aparentemente tem motivações sociais em prol da coletividade.

Podemos tomar como exemplo as Associações envolvidas em "proteger" ou "revitalizar" ${ }^{29}$ determinadas áreas da cidade de seus interesses. As principais associações ligadas com tal compromisso são: Associação Viva o Centro, criada em 1991, que procura desde então reverter, ou ao menos conter, o processo de migração de empresas do centro antigo para outras centralidades da cidade. A principal vitória da Associação foi marcada pela negociação em manter a Bolsa de Valores de São Paulo (Bovespa) e a Bolsa de Mercadorias \& Futuros (BM\&F).Essa negociação teve forte participação do setor financeiro representado pelo Banco de Boston, associação que tem entre seus participantes desde pequenos comerciantes até instituições bancárias, mostrando certo nível de heterogeneidade, "ainda que não possa abarcar um conjunto tão plural de demandas nem pretenda priorizar as necessidades mais ligadas às camadas populares" (FRÚGOLI, 2001).Outra característica dessa associação é a proximidade que mantém com o poder público local; A segunda é a Associação Paulista Viva, criada em 1995, que tem origem no próprio poder público, e depois conseguiu relativa independência já como associação; o processo foi gerido pelo presidente do Banco Itaú, que teve como conquista a eleição da Avenida Paulista como "símbolo da cidade"; também foi possível recuperar o patrimônio arquitetônico representado por antigos casarões da Paulista, através de uma negociação social em torno do que estaria efetivamente em degradação (FRÚGOLI, 2001).

A característica comum às duas associações é o fato de ambas terem entre seus atores mais ativos instituições financeiras, além de manterem relações diretas com o poder

\footnotetext{
${ }^{29}$ Processo de "revitalização" entendido como intervenção,seja na estrutura, forma ou conteúdo urbano.
} 
público local; essa característica vai aparecer de maneira mais indireta quando nos referirmos aos atores que agiram na formação da centralidade da Avenida Engenheiro Luiz Carlos Berrini. Nesse caso, tratou-se de uma única empresa que deu início ao processo de reestruturação do espaço urbano na região; e a exemplo do que aconteceu na Berrini, a valorização da extremidade do quadrante sudoeste, a marginal do Pinheiros, é promovida e defendida principalmente por uma empresa multinacional de consultoria ${ }^{30}$. Ou seja, nesses últimos casos o caráter é diretamente comercial envolvendo o capital imobiliário e financeiro $^{31}$. Pode-se pensar que não há problema diretamente relacionado ao fato de essa valorização na extensão do quadrante sudoeste ser defendida por uma multinacional ou o caráter da atividade ser estritamente comercial, porém é preciso investigar outros fatores como a pertinência em se concentrar ainda mais a atividade econômica na área urbanizada mais consolidada da cidade e a que custo isso vem sendo realizado, em detrimento de áreas públicas ou de antigas áreas residenciais, e com dinheiro público concentrado em uma pequena área da cidade.

Para bem avaliar um território é fundamental identificar os atores que nele atuam, sendo eles do poder público ou privado. A ação desses atores tem ligação direta com a dinâmica urbana da cidade de São Paulo, por desempenhar papel decisivo na condução das políticas públicas e iniciativas privadas, muitas vezes estreitamente associadas. Os efeitos dessas ações serão objetos de análise para compreendermos a transformação da estrutura urbana.

O processo histórico de conformação dos espaços centrais, aqueles de comando, tem muito a nos dizer sobre a atuação dos agentes públicos e privados na cidade. Tal análise será desenvolvida em seguida ao abordarmos o tema de formação de centralidades hegemônicas na cidade de São Paulo, quando chegaremos a uma representação do cenário atual. Na sequência, trataremos das novas centralidades ou aquelas em potencial, uma vez que ainda não se conformaram em plenitude. Assim poderemos realizar um quadro com as centralidades hegemônicas e novas centralidades da cidade a fim de identificar os pontos fortes e fracos dessa distribuição, bem como suas interações e funções complementares, e seu impacto nos fluxos diários na cidade.

\footnotetext{
${ }^{30}$ Ver FRÚGOLI, H. JR. A questão das centralidades em São Paulo: o papel das associações de caráter empresarial. Revista de Sociologia e Política. Paraná, Universidade Federal do Paraná, n. 16, p. 51-66, jun.2001.

${ }^{31}$ Ver CARLOS, A. F. A. Espaço-Tempo na Metrópole. São Paulo, Contexto, 2001.
} 


\section{A formação das centralidades hegemônicas}

A ação normativa do Estado sobre o território da cidade, no que diz respeito à formação de novas centralidades, tem um de seus primeiros registros no Código de Obras Arthur Saboia, formulado em 1929 e consolidado em 1934, onde se estabelecia alturas máximas para prédios no centro antigo (Rua São Bento) que deveriam ter seis andares, para a nova centralidade que se formava (Rua Barão de Itapetininga e 7 de Abril) era de 10 andares e, fora dessas duas áreas, 27 andares (SOMEKH, 1993). Demonstrando assim, que a ação normativa do Estado (no caso poder municipal) tem grande efeito nas transformações territoriais desde o primeiro "deslocamento" de sua centralidade, antes localizada nas Ruas XV de Novembro, Álvares Penteado, Direita e São Bento (região da Praça Sé), e depois, atravessando o Vale do Anhangabaú, nas Ruas Barão de Itapetininga, 7 de Abril e Avenida Ipiranga (região do Praça da República). Contudo, é necessário dizer que as formas encontradas na primeira centralidade da cidade, assim como seu espaço físico, não supria as necessidades que se impunham. $\mathrm{O}$ crescimento da cidade como um todo demandava novas áreas de comércio e de serviços, local onde a circulação pudesse ser realizada com maior eficiência, ou seja, o território deveria possuir maior fluidez.

Ainda em 1968, o centro antigo (Sé e República) concentrava a maior parte das grandes empresas (CORDEIRO, 1993). Contudo, pouco antes, em 1962, a Avenida Paulista foi transformada em um centro comercial, com boa infraestrutura, hospitais, escolas, cinemas, teatros, empresas de rádio e televisão, equipamentos, que foram sendo inseridos desde o aumento da densidade populacional no local por volta dos anos 1930, com as construções de edifícios residenciais; somado a essas transformações, a Avenida Paulista era símbolo da elite paulista, característica que foi apropriada pelas grandes empresas que migraram seus escritórios centrais para lá em busca de maior prestígio (CORDEIRO, 1993). Com isso, em poucos anos, a Avenida Paulista se tornaria uma nova centralidade, expandindo sua área de influência e abarcando avenidas próximas, ao ponto de alguns se referirem como "região da Paulista".

Segundo Frúgoli Jr. (2000), quando a Avenida Paulista alcança seu apogeu na passagem da década de 1980 para 1990, começam a aparecer sinais de uma "deterioração", com a fuga de empresas e de investimentos públicos aplicados em outras áreas da cidade, num processo semelhante ao que aconteceu com o centro antigo. A Paulista sofreu dos mesmos problemas do centro antigo, mas com um agravante: ela apresenta poucas áreas incorporáveis, 
e as que são possíveis de serem aproveitadas estão muito caras, inviabilizando a execução de novos projetos. Logo houve a ocupação das ruas paralelas e, como tendência, a avenida caminha para estagnação à medida que surge o crescimento em direção aos Jardins (CARLOS, 2001).

É justamente em direção ao Sudoeste que a concentração de grandes empresas, principalmente ligadas ao setor financeiro e terciário moderno, vem se constituindo. Isso pode ser considerado a mais recente centralidade de São Paulo; trata-se do eixo Avenida Faria Lima/Avenida Eng. Luiz Carlos Berrini, ou simplesmente "região da Berrini". O processo de concentração dessas empresas na área conhecida como quadrante sudoeste (ROLNIK et. al. 1990; CORDEIRO, 1993; FRÚGOLI, 2000) apresenta algumas tendências e características que trataremos adiante. Por ora, é importante situar as três grandes centralidades da cidade de São Paulo que têm características de ocupação e funcionalidade diferentes entre si e por isso mesmo têm capacidade de atração diferente, considerando todos os principais fluxos que já apontamos, a saber, migratórios, de mercadorias, informacionais, monetários e financeiros. Além dos fluxos, destacam-se a capacidade de atração de empresas e investimentos públicos.

Esse conjunto de centralidades, que toma parte de uma grande área da cidade, pode ser chamado de Complexo Corporativo da Metrópole, "conjunto de sedes das grandes empresas de todos os setores da economia e dos seus serviços correlatos" (CORDEIRO, 1993); ainda dá para destacar que as sedes das grandes empresas migraram do centro antigo para a Avenida Paulista e depois para Berrini (região) e que essas sedes de grandes corporações representam os principais agentes privados na condução tanto da produção do espaço até a estruturação interna da cidade.

É necessário perseguir a ideia de localização dos serviços avançados no interior dos territórios da metrópole. Esses se dão em áreas que expressam o policentrismo, o qual vem progressivamente se desenvolvendo. E o que é interessante é que essa multicentralidade apresenta uma hierarquia segundo o grau de internacionalização das atividades que nelas se desenvolvem, sendo o topo da pirâmide ocupado pelas áreas onde o grau de internacionalização dos serviços é maior, expresso pela presença de firmas estrangeiras e pelos vínculos densos com o exterior no desenvolvimento dos negócios (LENCIONI, 2008, p. 14). 
O setor de serviços, por se tratar de um conjunto de atividades em constante transformação em meio a um processo de inovação constante e acelerado, transfere esse dinamismo para o meio físico, o território. Com isso observamos diversas alterações nos padrões de uso do solo na cidade, assim como a constante alteração nas funções de inúmeros objetos urbanos.

Para visualizar esse núcleo dinâmico, especializado, ou ultraespecializado nas palavras de Bessa (2012, p. 128), exibimos o mapa seguinte, chamado de Complexo Corporativo Metropolitano (CCM), elaborado pelo Centro Brasileiro de Análise e Planejamento (CEBRAP), que procura compartimentar o $\mathrm{CCM}^{32}$. Caracterizado com uma área que aponta três "polos": o primeiro é o Centro Histórico; depois vem a Avenida Paulista; e o último é o chamado quadrante sudoeste, entendido como o agrupamento dos vetores Avenida Faria Lima, Avenida Luiz Carlos Berrini, Avenida Verbo Divino e a Marginal do Pinheiros. Ainda foram incorporadas, e no mapa destacadas, duas áreas industriais: ao sul da cidade, o Centro industrial Jurubatuba, onde se encontram empresas de alta intensidade tecnológica, segundo Álvaro Comin et al (Org.) (2012); e próximo ao centro da cidade, o Centro industrial Bom Retiro/Brás, importante conglomerado de indústrias tradicionais.

(...) as empresas são atraídas para essa área em função dos atributos específicos da economia urbana, na qual os investimentos públicos em infraestrutura e a forma de regulação do uso do solo se combinam com a dinâmica do mercado imobiliário, fazendo com que as empresas passem a gravitar em torno do núcleo econômico do município conforme as diversas possibilidades de combinações entre esses fatores (BESSA et al, 2012, p. 130).

São essas as centralidades hegemônicas da cidade, ou seja, aquelas em que a força centrípeta age tanto nos investimentos públicos e privados quanto nos impulsos de modernidade e inovação. Centralidades antigas e contemporâneas que dividem funções de comando na economia urbana da cidade e na economia nacional. Núcleos de inquestionável força de atração de todos os tipos de fluxos possíveis: pessoas, mercadorias, dinheiro e informação. Constituindo-se assim nos principais nós da cidade de São Paulo.

\footnotetext{
${ }^{32}$ Importante destacar que aqui o CCM aparece muito maior do que idealizado pela autora que o definiu, Helena Kohn Cordeiro (1993).
} 


\section{Mapa 15 - Complexo Corporativo Metropolitano}

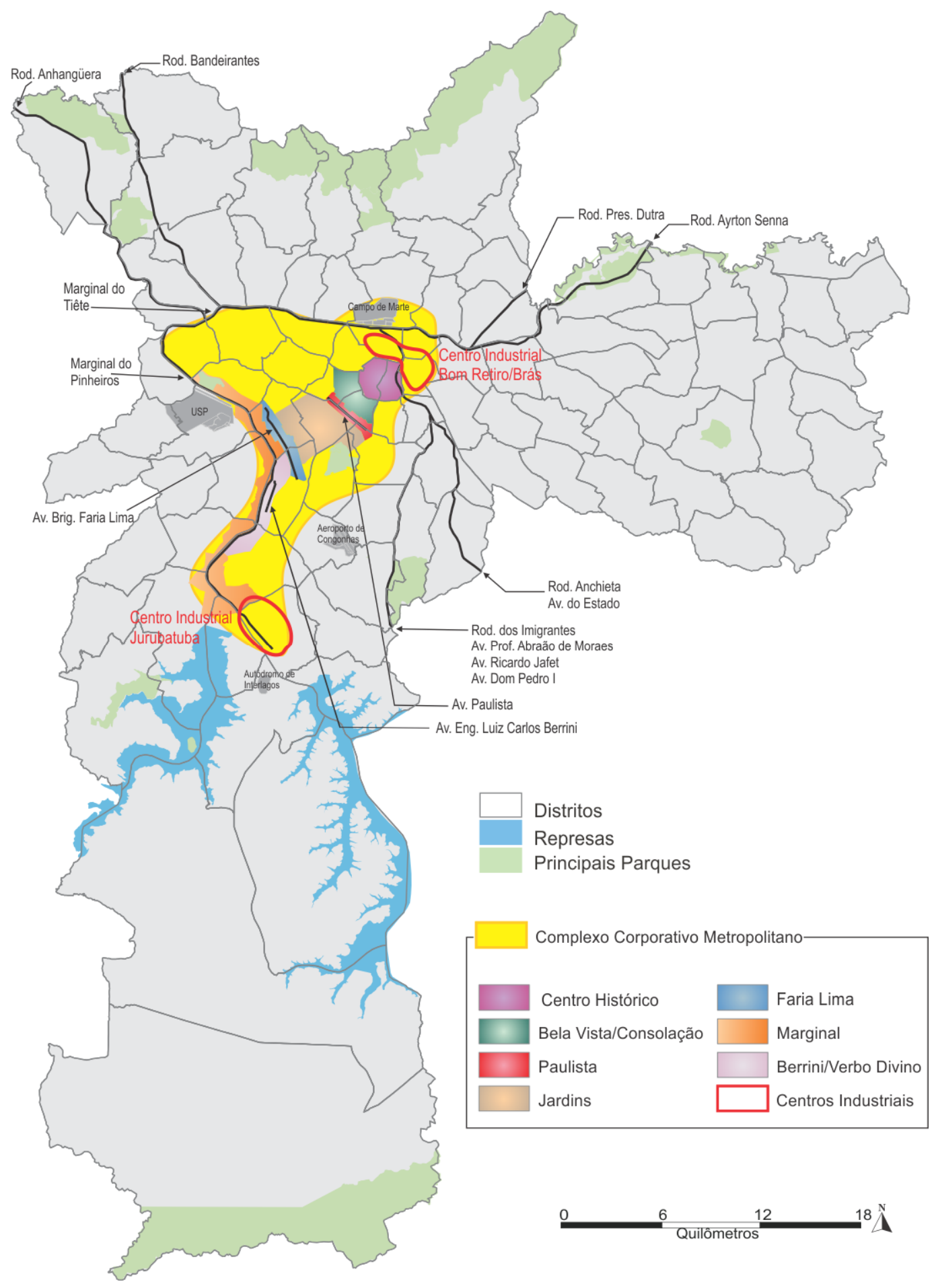

Fonte: Centro Brasileiro de Análise e Planejamento - Cebrap, 2008

Base cartográfica: Secretaria Municipal de Planejamento - Sempla/Dipro 


\section{Novas centralidades}

Quando nos referimos a políticas públicas e vetores de desenvolvimento urbano com finalidade de criação de novas centralidades, estamos falando da ação do Estado em associação com os setores privados que agem sobre a estrutura urbana da cidade, alterando antigos espaços para construção de subespaços especializados com todos os atributos necessários aos interesses comerciais.

Todo o tipo de intervenção na estrutura urbana deve levar em conta as formas anteriores, seus conteúdos, pois:

Depois que se forma a paisagem física e social da urbanização de acordo com critérios caracteristicamente capitalistas, certos limites se interpõem nas vias futuras do desenvolvimento capitalista. Isso implica que, embora o processo urbano sob o capitalismo seja moldado pela lógica da circulação e da acumulação do capital, aqueles critérios modelam as condições e as circunstâncias da acumulação do capital em pontos posteriores do tempo e do espaço (HARVEY, 2005, p. 175)

Se pensarmos que as formas moldadas na estrutura urbana da cidade estão localizadas no centro antigo ou em áreas de atividade econômica longínqua e/ou já desativadas (como por exemplo, indústrias), perceberemos que essas áreas sofrem constantemente intervenção urbana tanto por parte do Estado como das empresas privadas, pois já não são úteis a determinadas funções econômicas contemporâneas. Contudo existe outro cenário possível, aquele onde o capital imobiliário especulativo age, como foi o caso da criação de projetos imobiliários voltados a lançamentos comerciais na região da Avenida Engenheiro Luiz Carlos Berrini. Essa ação promovida por uma única empresa, a princípio a Bratke-Collet (FRÚGOLI, 2000), pode parecer independente do poder público, mas a ação do Estado se deu pela operação urbana Águas Espraiadas, com a construção da Nova Faria Lima, que constitui um corredor até a Avenida Eng. Luis Carlos Berrini; assim com a associação direta ou indireta temos o capital imobiliário junto com o financeiro e o poder do Estado agindo sobre uma área anteriormente residencial (CARLOS, 2001). Essa combinação deu 
inicio ao mais recente centro de negócios; é nessa região onde se localiza a maior parte dos prédios inteligentes da cidade. Segundo dados da Empresa Paulista de Planejamento Metropolitano - Emplasa São Paulo tem 29 prédios inteligentes classe AA, sendo que 40,9\% nas proximidades da Avenida Eng. Luis Carlos Berrini, 23,4\% na Marginal do Pinheiros, 10,3\% na Avenida Verbo Divino (“continuação" da Berrini), 10,4\% na Avenida Faria Lima ${ }^{33}$. Toda essa pujança foi bem explorada pelos setores imobiliários que passaram a vender a idéia de um centro decadente (o centro antigo), que a Paulista já não era funcional e estava saturada, e que a região da Berrini se constituía como a solução, o mais novo e moderno centro de negócios para São Paulo.

Como aponta Frúgoli (2000), a Berrini, ainda que tenha potencial de crescimento, já sofre concorrência por grandes empresas do setor terciário próximas à Marginal do Pinheiros. Essemovimento que desloca o núcleo da centralidade do subespaço para a margem do "quadrante sudoeste" tem o seu mais forte representante na empresa multinacional de consultoria Richard Ellis; para ela, a Berrini de certa maneira já estaria obsoleta e a expansão do complexo corporativo deveria se dar em direção à Marginal do Pinheiros.

Pelo exposto, há uma indicação que não são mais as formas classificadas de obsoletas o real motivo das intervenções na estrutura urbana. Os limites das paisagens físicas e sociais de que nos falava Harvey (2005) parecem não ser a única motivação para cada vez mais se investir em novos centros de negócio. Ocapitalismo encontra no capital especulativo imobiliário, associado ao capital financeiro, outra forma de acumular e de se reproduzir, através da produção do espaço urbano como mercadoria (CARLOS, 2001). Se entendermos que as lógicas locacionais das empresas não são totalmente definidas por motivos técnicos e físicos, como mostramos no segundo capítulo deste trabalho, fica claro compreender que tal processo de reconfiguração da estrutura urbana, com a produção de novos espaços ou reprodução do espaço ${ }^{34}$, se dá com o objetivo de criar possibilidades reais de novos negócios. Um indício que reforça tal argumento pode ser encontrado quando analisamos o crescimento do estoque vago entre os edifícios de escritórios. Entre os anos de 1995 a 1998, o estoque total útil aumentou 9\%, enquanto o estoque vago aumentou $32 \%$, no centro antigo; isso representou um acréscimo de estoque vago de 200 mil metros quadrados passando de 356 para 556 mil

\footnotetext{
${ }^{33}$ Informações obtidas em: BESSA, V. C. O setor de serviços às empresas. In: EMURB/CEBRAP. (Org.). Caminhos para o centro. São Paulo, 2004.

A definição da classificação dos prédios: Classe AA - comporta sistema de ar condicionado central por tempoacumulação e controle de volume de ar variável, sistema de prevenção e combate a incêndio, piso elevado, internet, ar-condicionado central, heliporto, número suficiente de garagens e gerenciamento predial.

${ }^{34}$ Conforme CARLOS (2001).
} 
metros quadrados; na Paulista passou de 111 para 158 mil metros quadrados- aumento de 57 mil metros quadrados - ; e na região da Marginal do Pinheiros passou de 109 para 207 mil metros quadrados - aumento de 102 mil metros quadrados (NOBRE, 2000). O estoque vago de área de escritórios em São Paulo continua elevado quando observamos os números divulgados pela pesquisa imobiliária On.Point São Paulo, $1^{\circ}$ trimestre de 2012, da empresa de consultoria Jones Lang LaSalle ${ }^{35}$.Em média, a cidade de São Paulo teve 11,9\% de taxa de vacância $^{36}$, sendo que a Berrini registrou $17,9 \%$, em função da entrega de novos empreendimentos.Ou seja, o processo de construção não para e segue a lógica de oferecer sempre as melhores condições, seja de localização, seja de infraestrutura ou de status.

Como podemos verificar no gráfico seguinte, a evolução dos novos estoques nos últimos anos se mantém em elevados índices, e para o primeiro trimestre de 2012, o valor é praticamente igual aos anos anteriores, o que provavelmente fará com que a taxa de vacância ao final do ano se eleve.

\section{Gráfico 4 - Novos estoques}

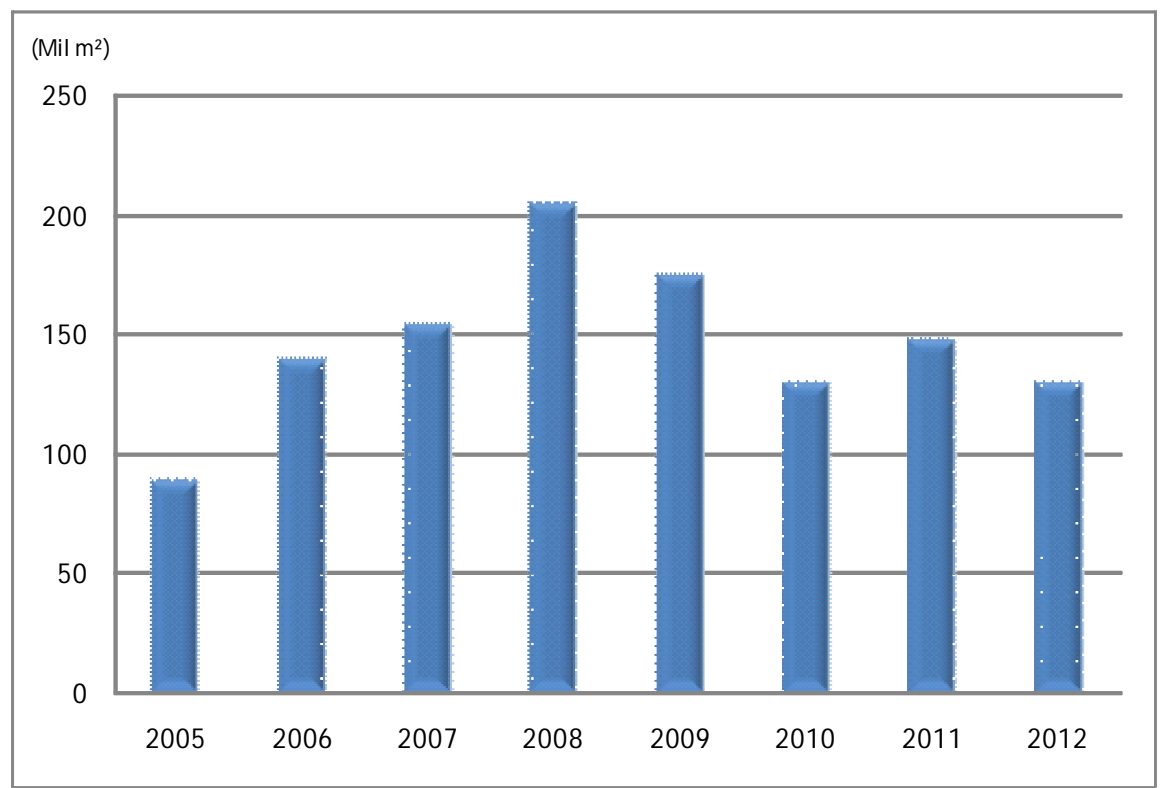

Fonte:Relatório CB Richard Ellis - Market View São Paulo (1º tri/2010 a $1^{\circ}$ tri/2012).

Elaboração: André de Freitas Gonçalves

\footnotetext{
${ }^{35}$ Disponível em: http://www.joneslanglasalle.com.br/ResearchLevel1/On.point S\%C3\%A3oPaulo_1\%C2\%BATrimestre2012.pdf

${ }^{36}$ Porcentagem de escritórios vagos, calculada em relação ao estoque total.
} 
O mercado imobiliário de edifícios comerciais ou de escritórios segue em ritmo acelerado, quando observamos a absorção líquida ${ }^{37}$ do ano de 2011 , que foi de $171 \mathrm{mil} \mathrm{m}^{2}$, volume pouco abaixo do registrado no ano anterior, porém, para o primeiro trimestre de 2012 já foi registrada absorção liquida de $101 \mathrm{mil} \mathrm{m}^{2}$, sendo que a região da Marginal do Pinheiros corresponde a $86 \%$ do total da cidade. No ano anterior tinha ficado com $47 \%$ do total e $66 \%$ quando restringimos a análise ao mercado classe A, segundo dados do Relatório CB Richard Ellis - Market View São Paulo, $4^{\circ}$ trimestre de 2011 e $1^{\circ}$ trimestre de 2012.

Sabemos que o processo de reestruturação do espaço urbano se dá a partir da criação do núcleo urbano, isto é, desde seu crescimento e desenvolvimento existe um constante arranjo, estruturação e reestruturação, a exemplo do que aconteceu com o centro antigo em sua primeira expansão. Isso quer dizer que o processo é constante e não é novo, entretanto o que há de novo no período atual é a intensidade desse processo "em que essa reestruturação do espaço se apresenta como um componente imediato de uma ampla reestruturação social e econômica ${ }^{38 "}$ (SMITH, 2007).

A expansão da área de escritórios sentido sudoeste da cidade funciona como um vetor de reestruturação urbana, pois consome todos os espaços possíveis de serem utilizáveis economicamente para esse fim, logo, não tem início e fim, sendo um processo que somente podemos delimitar temporalmente, como um retrato. Quando Frúgoli (2000) estudou e delimitou o quadrante ou vetor sudoeste da cidade, a Marginal do Pinheiros não tinha a importância que tem hoje no mercado imobiliário comercial e residencial. Ainda que o autor tenha observado o movimento em direção a Marginal, não se considerava a forte expansão de novos edifícios e conjuntos comerciais e residenciais, sobretudo na sua porção sul, para além do Centro Empresarial São Paulo ${ }^{39}$. Na figura seguinte, encontramos as regiões de escritórios da cidade de São Paulo delimitadas por uma empresa de consultoria imobiliária, onde podemos observar a subdivisão da Marginal do Pinheiros em três, a saber: Marginal Norte, Marginal e Marginal Sul. Tamanha importância esse eixo tomou que agora passou a incorporar a outra margem do rio e foi subdividido, pois sua extensão é relativamente grande e apresenta diferenças na ocupação e uso, o que reflete no seu valor de mercado.

\footnotetext{
${ }^{37}$ Aumento real do espaço ocupado no período.

${ }^{38} \mathrm{O}$ autor se refere principalmente aos países capitalistas avançados, contudo indica tais transformações em cidades do "terceiro mundo" numaproporçãodiferente. A diferença de intensidade e característica nas reestruturações urbanas se dá inclusive internamente aos países capitalistas avançados.

${ }^{39}$ Ver PADUA, R. F. de. Produção e consumo do lugar: espaços de desindustrialização na reprodução da metrópole. Tese (Doutorado em Geografia (Geografia Humana - Universidade de São Paulo - FFLCH, 2012. .Implicações socioespaciais da desindustrialização e da reestruturação do espaço em um fragmento da metrópole de São Paulo. São Paulo, FFLCH, 2008.
} 
Figura 7 - Regiões de escritórios

\section{São Paulo | Regiöes de escritórios Office regions}

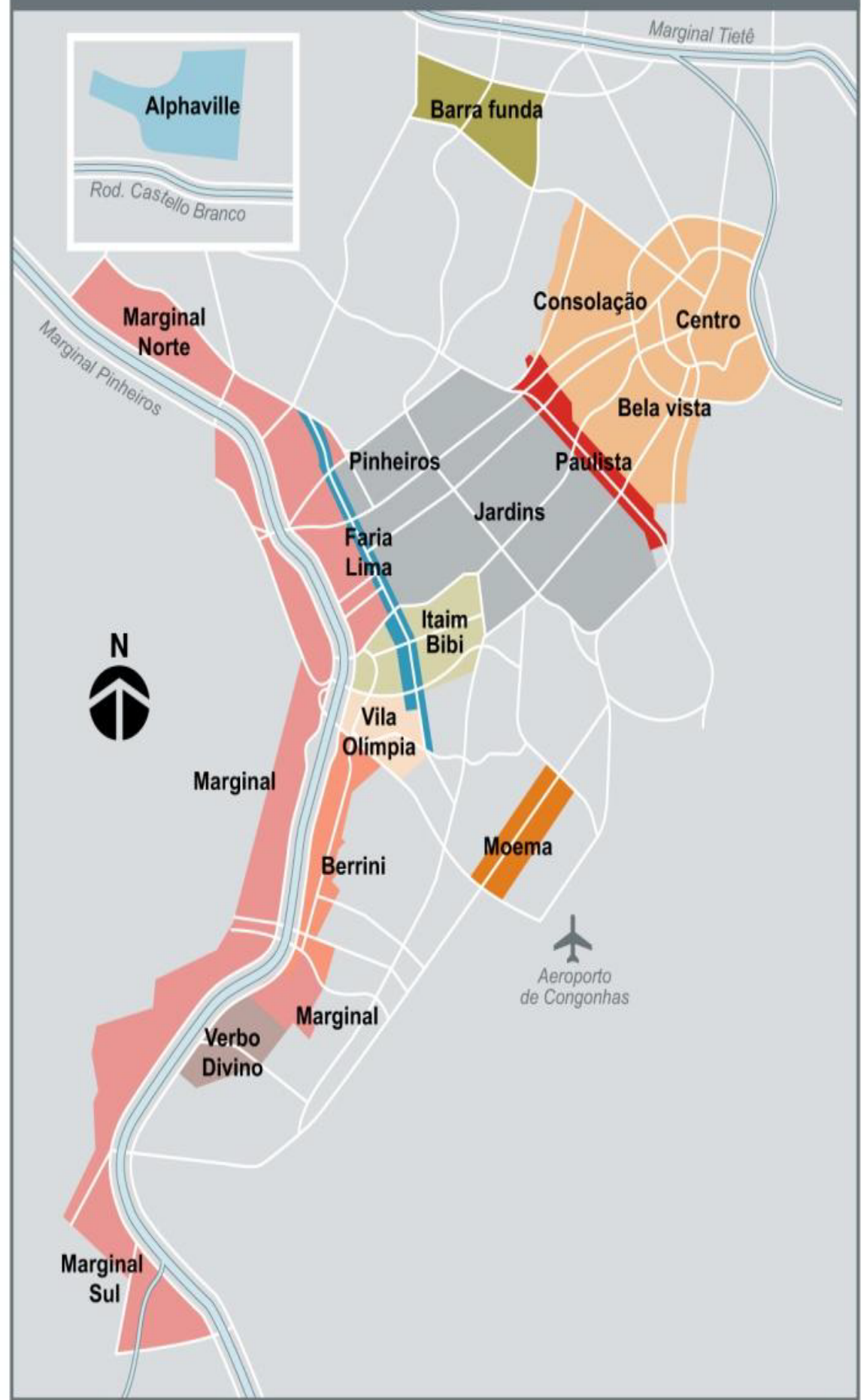

Fonte: Jones Lang LaSalle. On.Point São Paulo, $1^{\circ}$ trimestre de 2012. 
Ainda sobre a figura anterior, podemos observar três áreas que a principio não se enquadram nas três centralidades hegemônicas aqui definidas (o Centro histórico, a Avenida Paulista e o eixo Avenida Faria Lima, Avenida Luiz Carlos Berrini e Marginal do Pinheiros), são elas: Moema, Barra Funda e Alphavile. Em seu relatório (On.Point São Paulo, $1^{\circ}$ trimestre de 2012), a empresa Jones Lang LaSalle classifica as regiões representadas na figura da seguinte forma:

- Regiões Nobres: Principais e mais valorizados corredores comerciais, onde se concentram importantes empresas. Paulista, Faria Lima, Itaim, Vila Olímpia e Berrini;

- Regiões Secundárias: Próximas as regiões nobres, com menor número de empreendimentos de alto padrão: Centro, Jardins, Verbo Divino e Marginal;

- Regiões Alternativas: regiões em processo de consolidação, fora do eixo tradicional de desenvolvimento de escritórios: Barra Funda, Moema e Alphavile.

Os critérios utilizados pela empresa ao classificar as áreas de escritório foram basicamente dois: a presença de empreendimento de alto padrão e o valor dos aluguéis por ser esse o objeto de trabalho da empresa. Contudo, temos boas referências ao investigar outras áreas que exercem alguma força sobre a localização de empresas e serviços. Como podemos perceber, o trabalho aponta para áreas alternativas às centralidades ou eixos tradicionais, áreas em consolidação, a saber, Barra Funda, Moema e Alphavile. As duas primeiras estão na cidade de São Paulo e a terceira faz parte da cidade de Barueri, que integra a Região Metropolitana de São Paulo, com acesso pela Rodovia Castelo Branco. Tornou-se importante centro de negócios que concorre com os da capital.

A importância aqui é destacar esse crescimento de outras centralidades que estão à margem das já consolidadas e tradicionais. São áreas ativas e dinâmicas que registram crescimentos recentes como indicam os relatórios da empresa Richard Ellis, ao destacar que no primeiro trimestre de 2011 a categoria Outros, composta por 11 setores, em sua maioria, mais afastados do Centro e das concentrações tradicionais de escritórios, inclui assim as centralidades de Moema e Barra Funda. 
Temos na tabela seguinte a classificação das chamadas sub-regiões da empresa CB Richard Ellis ${ }^{40}$, apresentando o estoque de locação e os novos estoques para o ano de 2011 e o primeiro trimestre de 2012. Importante notar a relevância, no ano de 2011, da

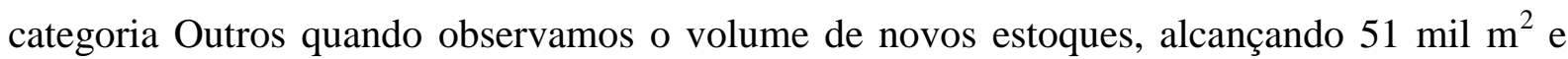
Alphaville registrando $154 \mathrm{mil} \mathrm{m}^{2}$ de novos estoques, superando o total da cidade de São Paulo no acumulado o ano de 2011. Isso provocou uma elevação na taxa de vacância em função do aumenta da oferta. Para o primeiro trimestre de 2012 não foram registrados novos estoques para a categoria Outros ou Alphaville, contudo vale o destaque para as centralidades tradicionais com fortes acréscimos, sobretudo a Marginal do Pinheiros, pois no total do primeiro trimestre de 2012 suas três áreas quase alcançam o acumulado do ano anterior. Ainda assim, observamos que, na participação de mercado, a categoria Outros registra 22\%, sendo superada somente pela Marginal do Pinheiros.

Tabela 4 - Estoque de locação e novos estoques de escritório

\begin{tabular}{|c|c|c|c|c|c|c|}
\hline \multirow{3}{*}{ Sub-regiões } & \multicolumn{2}{|c|}{2011} & \multirow{2}{*}{\multicolumn{3}{|c|}{$\frac{2012}{1^{\circ} \text { Trimestre do ano }}$}} & \multirow{3}{*}{$\begin{array}{l}\text { Participação } \\
\text { de Mercado }\end{array}$} \\
\hline & \multirow{2}{*}{$\begin{array}{c}1^{\circ} \text { Trimestre do ano } \\
\text { Estoque de locação } \\
\mathrm{m}^{2} / \mathrm{mês}\end{array}$} & \multirow{2}{*}{$\begin{array}{l}\text { Acumulado do ano } \\
\text { Novo estoque } \mathrm{m}^{2}\end{array}$} & & & & \\
\hline & & & $\begin{array}{c}\text { Estoque de } \\
\text { locação } \mathrm{m}^{2} / \mathrm{mês}\end{array}$ & & $\begin{array}{l}\text { estoque } \\
\mathrm{m}^{2}\end{array}$ & \\
\hline Centro & 362.400 & 一 & 362. & & - & $6 \%$ \\
\hline Paulista & 1.022 .400 & 一 & 1.036 .6 & & 13.300 & $17 \%$ \\
\hline Jardins & 980.000 & 21.700 & 1.043 .3 & & 34.900 & $17 \%$ \\
\hline Marginal & 2.212 .900 & 75.300 & 2.386 .5 & & 81.400 & $39 \%$ \\
\hline Outros & 1.319 .800 & 51.100 & 1.364. & & - & $22 \%$ \\
\hline Total MSP ${ }^{(1)}$ & 5.897 .500 & 148.100 & 6.193.7 & & 129.600 & $100 \%$ \\
\hline Alphaville & 437.300 & 154.000 & 601.6 & & - & - \\
\hline
\end{tabular}

Fonte: CB Richard Ellis. Market View São Paulo, $1^{\circ}$ tri $/ 2011,2^{\circ}$ tri $/ 2011,3^{\circ}$ tri $/ 2011,4^{\circ}$ tri $/ 2011$ e $1^{\circ}$ tri/2012.

Elaboração: André de Freitas Gonçalves

(1) Município de São Paulo

\footnotetext{
${ }^{40}$ ColdwellBankerRichard Ellisé uma das maiores empresas de consultoria imobiliária do mundo.Produz e disponibilizaum relatório trimestral, oMarketView, contendo dados estatísticos e análises geradas para um segmento específico do mercado imobiliário. Disponível em: http://www.cbre.com.br/informativo-marketview Acesso em: 15.mai.2012.
} 
Com o crescimento da cidade, seu espraiamento alcança cada vez mais os limites administrativos do município e transpõe tais a ponto de promover a conurbação da mancha urbana com os municípios vizinhos. Esse processo faz com que a cidade ganhe diversos centros secundários, que exercem determinada atração de acordo com a variedade de funções e serviços presentes, a densidade de seu entorno e em sua localização relativa na estrutura urbana da cidade, quer quando esteja próxima ou na formação de um nó central, na confluência de fluxos por meio de cruzamentos de diversas redes.

Portanto, é preciso reconhecer esses centros secundários e seu funcionamento dentro da dinâmica da cidade. Essas centralidades são hierarquizadas em função da sua força de atração, tanto de pessoas quanto de dinheiro e informação. É medida por sua densidade técnica, sua capacidade de aumentar a espessura do território por meio da expansão do espaço geográfico em áreas cada vez mais compactas, feita por meio do adensamento de pessoas e empregos, promovido pela construção vertical.

O processo de desenvolvimento e expansão das centralidades é amparado pelo poder público por meio da criação de um arcabouço normativo. Especificamente, o executivo municipal procura incentivar a criação de novos centros de negócio, por meio de diversos planos, projetos e leis, e fortalecer os já existentes por meio de numerosos instrumentos urbanísticos, possíveis de ser aplicados após a criação da Lei Federal n ${ }^{\circ} 10.257$, de 10 de julho de 2001, conhecida como Estatuto da Cidade. Coma criação do Estatuto da Cidade, que regulamenta os artigos 182 e 183 da Constituição Federal de 1988 que tratam da política urbana, todos os municípios com mais de 20 mil habitantes foram obrigados a criar um Plano Diretor, a ser aprovado por lei municipal, que é o instrumento básico da política de desenvolvimento e expansão urbana.

A cidade de São Paulo teve assim formulado e aprovado seu Plano Diretor, conhecido como Plano Diretor Estratégico (PDE) em 13 de setembro de 2002, na Lei Municipal 13.430/2002. Foi regulamentado com a promulgação da Lei $\mathrm{N}^{\circ} 13.885$, de 25 de agosto de 2004, chamada Lei Disciplina e Ordena o Parcelamento, Uso e Ocupação do Solo (Luos), mais conhecida como lei de zoneamento da cidade. Estabelece normas complementares ao Plano Diretor Estratégico, institui os Planos Regionais Estratégicos das 31 Subprefeituras e dispõe sobre o parcelamento, a disciplina e ordena o uso e a ocupação do solo do Município de São Paulo. 
Esse conjunto normativo traz elementos novos para definição de políticas urbanas, porém, resgata e legitima instrumentos urbanísticos que já vinham sendo utilizados. Como já apontamos, uma das primeiras legislações que procura ordenar o desenvolvimento urbano na cidade foi o Código de Obras Arthur Saboia, formulado em 1929 e consolidado em 1934 por meio do Ato $\mathrm{n}^{\circ} 663^{41}$, e somado a uma série de outros atos, leis, decretos, decretos-leis, se constituía uma legislação que tratava de ordenar o espaço urbano, disciplinando o uso e ocupação do solo. Contudo, isso se aplicava somente para algumas áreas e ruas da cidade. Foi somente depois da elaboração do Plano Diretor de Desenvolvimento Integrado/PDDI - Lei $n^{\circ}$ 7.688/71, que foi aprovada a primeira lei de zoneamento a dispor sobre o parcelamento, uso e ocupação do solo do município por inteiro, a Lei n ${ }^{\circ}$ 7.805, de 01 novembro de 1972.

A diferença da lei de 1972 para o Plano Diretor e o novo zoneamento de 2004 é notável. A cidade cresceu rapidamente e multiplicou funções, alcançando tamanha complexidade que reflete nas legislações urbanísticas e de uso e ocupação do solo nos dias atuais. A partir de 2004, contamos com um arcabouço normativo que procura, dentro de outras finalidades, promover o desenvolvimento urbano e econômico de maneira harmônica a fim de construir espaços qualificados com boas condições de vida e capaz de proporcionar condições favoráveis às atividades econômicas exercidas. Para tanto, faz uso de instrumentos urbanísticos para requalificar ou criar novos trechos ou polos dinâmicos na cidade. Um dos meios técnicos possíveis de serem utilizados é a definição de Áreas de Intervenção Urbana (AIU) que são porções do território de especial interesse para o desenvolvimento urbano, objeto de projetos urbanísticos específicos, nas quais poderão ser aplicados instrumentos de intervenção, previstos na Lei Federal n ${ }^{\circ}$ 10.257, de 10 de julho de 2001 - Estatuto da Cidade, que de forma geral pode servir para diferentes objetivos, por exemplo: para fins de regularização fundiária, execução de programas e projetos habitacionais de interesse social, constituição de reserva fundiária, ordenamento e direcionamento da expansão urbana, implantação de equipamentos urbanos e comunitários, criação de espaços públicos de lazer e áreas verdes, criação de unidades de conservação ou proteção de outras áreas de interesse ambiental.

Em São Paulo, existem as AIU em linhas de transporte público coletivo, “com o objetivo de qualificar estas áreas e seu entorno, a fim de obter recursos para aplicação na

\footnotetext{
${ }^{41}$ Veja como essa legislação direcionou o crescimento da cidade em: SOMEKH, N. Globalização e forma urbana: a intervenção urbanística na cidade de São Paulo. In: SANTOS, M. et al. O novo mapa do mundo: fim de século e globalização. São Paulo, Hucitec/Associação Nacional de Pós-Graduação e Pesquisa em Planejamento Urbano e Regional, 1993.
} 
implantação e melhoria das linhas de transporte público por meio da outorga onerosa do potencial construtivo adicional” (Lei 13.430/2002, Plano Diretor Estratégico, artigo 122), delimitadas por:

I - faixas de até 300 (trezentos) metros de cada lado dos alinhamentos do sistema de transporte público coletivo de massa;

II - círculos com raio de até 600 (seiscentos) metros tendo como centro as estações do transporte metroviário ou ferroviário.

A aplicação das AIU também está prevista no Plano Diretor para implantação ou melhoria de vias estruturais, de parques lineares, em polos e eixos de centralidades. Em todos os casos, o objetivo é obter recurso para fazer melhorias em espaços específicos da cidade já definidos no Plano Diretor e que são objetos de atenção por parte da prefeitura que almeja implementar projetos nessas áreas.

O mecanismo que possibilita o poder público municipal de obter recursos para o investimento em melhorias no espaço urbano é a outorga onerosa ${ }^{42}$ do direito de construir, também conhecido como "solo criado". Na cidade de São Paulo, por meio do Plano Diretor e Lei de Zoneamento, foi definido um coeficiente de aproveitamento básico e um coeficiente de aproveitamento máximo para casa zona de uso. Os coeficientes básicos podem ser 1 ou 2, e os máximos podem ser 1, 2, 2,5 e 4.Multiplicando esses números pela área de um lote, se tem a quantidade máxima permitida para ser construída no mesmo. Caso o proprietário de um terreno construa utilizando o coeficiente básico, ele não terá que pagar a prefeitura por isso, porém, se quiser construir até o limite máximo permitido, ele poderá mediante pagamento de contrapartida financeira ${ }^{43}$. Para cada distrito municipal ${ }^{44}$, foi definido um estoque de área adicional de construção, que pode ser obtido mediante pagamento da outorga onerosa. Os recursos são direcionados para o Fundo Municipal de Urbanização (FUNDURB) e utilizados na implantação de melhorias na cidade como um todo. A diferença, para o caso de terrenos localizados em AIU ou em área de Operação Urbana Consorciada, é que o coeficiente de aproveitamento pode ser superior ao estabelecido na lei de zoneamento e os recursos obtidos devem ser aplicados no perímetro específico da intervenção urbana.

\footnotetext{
${ }^{42}$ A outorga onerosa está prevista pelos artigos 28, 29, 30 e 31 da Lei Federal 10.257 de 2001 (Estatuto da Cidade) e definida nos artigos de 209 ao 216 do Plano Diretor Estratégico de 2002 do Município de São Paulo. ${ }^{43} \mathrm{O}$ cálculo da contrapartida financeira, que corresponde à outorga onerosa de potencial construtivo adicional, está definido na Lei 13.430/2002, artigo 213.

${ }^{44}$ Lei municipal $n^{\text {o }} 11.220 / 1992$,que cria e delimita os 96 distritos da cidade.
} 
Outro instrumento que a municipalidade utiliza no desenvolvimento urbano é a criação de área de Operações Urbanas Consorciadas (OUC). Cada operação urbana consorciada é criada por meio de lei específica, onde constam as finalidades da intervenção, a abrangência, programa de intervenções entre outras prerrogativas estabelecidas no artigo 229 do Plano Diretor. Os recursos obtidos só poderão ser utilizados dentro do perímetro da operação urbana e respeitando o programa de intervenções. O meio de obtenção de recursos nas OUC baseia-se na venda de Certificados de Potenciais Adicionais Construtivos (Cepacs $^{45}$, que são títulos, em bolsa de leilões, no caso na Bolsa de Valores de São Paulo (Bovespa), que podem ser livremente negociados. “(...) é uma forma de contrapartida financeira de outorga onerosa do potencial construtivo adicional, da alteração de uso e de parâmetros urbanísticos, para uso especifico nas Operações Urbanas Consorciadas" (Lei $13.885 / 2004$, artigo $2^{\circ}$, inciso XIII). A diferença principal nesta contrapartida financeira nas OUC é que por meio de venda dos títulos a prefeitura acaba por antecipar a arrecadação dos recursos financeiros, assim podendo realizar as intervenções previstas.

Outro instrumento de intervenção urbana, utilizado recentemente, mas previsto no Plano Diretor de 2002, na seção IX, é a concessão urbanística “... destinada à realização de urbanização ou de reurbanização de parte do território municipal a ser objeto de requalificação da infraestrutura urbana e de reordenamento do espaço urbano com base em projeto urbanístico específico" (Lei municipal $n^{\circ} 14.917 / 2009$, artigo $1^{\circ}$ ). Na prática, o que temos é a terceirização de áreas para a iniciativa privada na execução de obras urbanísticas de várias características a serem definidas no plano de intervenção. A empresa lucra, dentre outras formas, por meio da alienação ou locação de imóveis, inclusive dos imóveis desapropriados e das unidades imobiliárias a serem construídas.

No início desse ano, a prefeitura aprovou a lei $n^{\circ} 15.525$, de 9 de janeiro de 2012, que institui o Projeto Estratégico de Intervenção Urbana (PEIU) - Parque de Eventos ExpoSP, previsto no art. 42 do Plano Regional Estratégico da Subprefeitura de Pirituba/Jaraguá46, e estabelece suas diretrizes urbanísticas. Os PEIU, igual às AIU, foram demarcados por toda a cidade quando da formulação e aprovação da lei $n^{\circ}$ 13.885/2004. O primeiro objetivo específico da criação do Parque de Eventos Expo-SP é:

\footnotetext{
${ }^{45}$ Segundo a Lei 13.430/2002, artigo 230, parágrafo $5^{\circ}$, a quantidade de Certificados de Potencial Construtivo Adicional de Construção - CEPACs,a ser emitida, é obrigatoriamente proporcional ao estoque de potencial construtivo adicional previsto para a operação, seus valores mínimos, as contrapartidas correspondentes, formas de conversão e limites de subsídios para aquisição de terrenos para construção de habitação de interesse social. ${ }^{46}$ Ver: Anexo II da Parte II da Lei no 13.885, de 25 de agosto de 2004.
} 
Criar uma nova centralidade de caráter metropolitano, com previsão de implantação dos seguintes equipamentos de infraestrutura urbana: pavilhões de feiras e exposições, centro de convenções, "shopping center", área de exposições descoberta, arena destinada a eventos, logística e apoio de montagem, suporte operacional para transporte e armazenamento de cargas, além de centro empresarial e hoteleiro, edifícios e empreendimentos comerciais, promovendo-se a ocupação ordenada da área, segundo diretrizes urbanísticas e ambientais previstas na legislação urbanística vigente, com as modificações contempladas nesta lei.(Lei $\mathrm{n}^{\circ}$ 15.525/2012, artigo $3^{\circ}$ ).

Os efeitos de cada instrumento urbanístico, de cada projeto ou legislação específica na estrutura urbana merecem um estudo aprofundado, o que não acontecerá aqui. Vale ressaltarmos sua importância no desenvolvimento da cidade ao longo do tempo, nas formas de condicionar o crescimento urbano e nas iniciativas de criar ou qualificar centralidades fora dos centros de negócio tradicionais.

No mapa 16, observamos os planos e projetos de intervenção urbana que fazem parte da agenda do poder público municipal. Começando com as operações urbanas, temos em execução na cidade quatro delas, a saber: Água Branca, Centro, Faria Lima e Águas Espraiadas, onde as duas primeiras não são operações urbanas consorciadas, logo, não fazem uso das Cepacs, obtém recurso principalmente por meio da outorga onerosa, ou seja, o ritmo de investimento e arrecadação se diferencia das outras duas. Se olharmos a arrecadação total das quatro, poderemos observar onde as transformações na estrutura urbana ocorreram com forte intensidade. OU Centro arrecadou cerca de 35 milhões de reais; a OU Água Branca 173 milhões; a OUC Água Espraiada, que segue o eixo Avenida Luiz Carlos Berrini, Avenida Água Espraiada, parte da Marginal Pinheiros e Rua Verbo Divino, cerca de 1,453 bilhões de reais e, finalmente; a OUC Faria Lima com cerca de 1,850 bilhões de reais. Outras três operações urbanas aparecem em projeto: OUC Lapa-Brás, que segue a linha férrea próxima à Marginal do Tietê, área tradicionalmente industrial e vai até o Brás; a OUC Mooca-Vila Carioca, que segue o eixo do Rio Tamanduateí, e também a linha férrea que liga a cidade de 
São Paulo à região do $\mathrm{ABC}^{47}$ : e a OUC Rio Verde-Jacu, no eixo da Avenida Jacu- Pêssego, que corta de norte a sul a zona leste da cidade. Essas três operações já têm o processo licitatório aprovado para que se façam os planos urbanísticos das operações, além de produzir estudos de impacto ambiental, de capacidade de suporte da infraestrutura de circulação, econômicos e um plano de comunicação para cada operação.

\section{Mapa 16 - Planos e projetos de intervenção urbana, 2012}

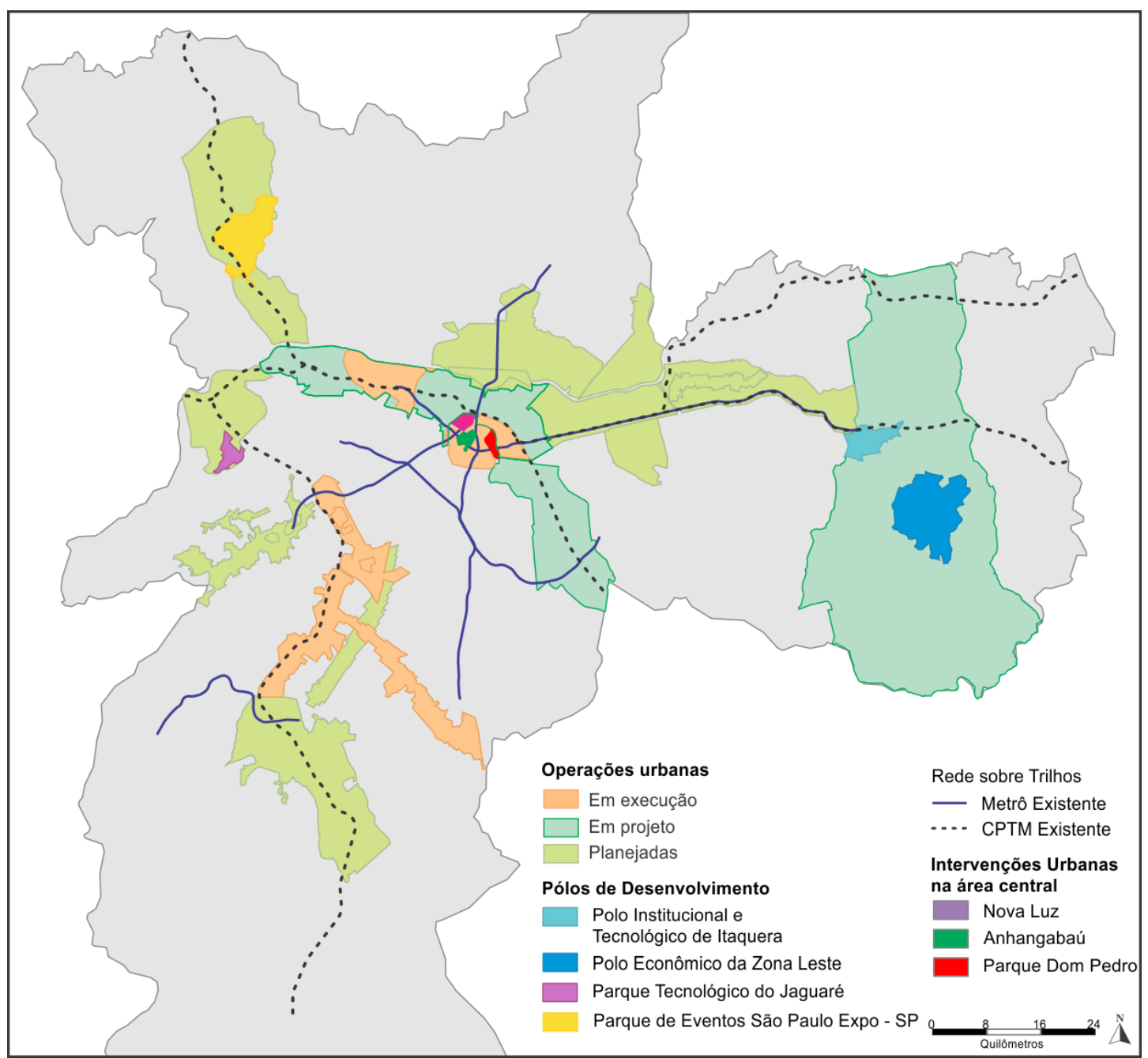

Fonte: Secretaria Municipal de Desenvolvimento Urbano - SMDU; Companhia do Metropolitano de São Paulo; Companhia Paulista de Trens Metropolitanos.

Elaboração: André de Freitas Gonçalves

As demais operações urbanas que aparecem no mapa como planejadas foram definidas no Plano Diretor de 2002 e sofreram pequenas alterações ao longo do tempo.

\footnotetext{
${ }^{47}$ Compreende os municípios de Santo André, São Bernardo do Campo, São Caetano, Diadema, Mauá, Ribeirão Pires e Rio Grande da Serra.
} 
Permanecem somente no papel, pois ainda não angariaram força para fazer parte da agenda do poder público municipal. Ainda no mapa, podemos observar a distribuição dos chamados polos de desenvolvimento, entre o quais dois estão localizados dentro da operação urbana consorciada (em projeto) Rio Verde-Jacu. São eles Polo Institucional e Tecnológico de Itaquera e Polo Econômico da Zona Leste. Para o primeiro, está prevista uma série de equipamentos que, em seu conjunto, forma o polo institucional. $\mathrm{O}$ pioneiro a ser construído será a Faculdade de Tecnologia (Fatec) Itaquera com entrega prevista para o fim de 2012.e já começaram as obras de uma ETEC - Escola Técnica do sistema Paula Souza. Ambos os empreendimentos são do governo do Estado de São Paulo. Outros equipamentos estão previstos como Fórum, Rodoviária, unidade do SENAI com cursos voltados ao setor industrial, Parque Tecnológico, Arena-SP, Posto da Polícia Militar, Centro de Convenções, Parque Linear e Centro Social Don Bosco. Próximo ao local também está sendo construído um novo estádio de futebol para sediar jogos da Copa do Mundo em 2014. O projeto de Polo Econômico é na área definida na lei de zoneamento de 2004, como Zona Predominantemente Industrial, e procura promover uma reestruturação urbanística na área a fim de atrair empresas. Esse também é o objetivo da lei municipal de incentivos seletivos número 14.654/2007, que promove subsídios fiscais a empresas que se instalarem na área em volta à Avenida Jacu-Pêssego. A área é exatamente o perímetro do Polo Econômico da Zona Leste.

Outros dois projetos estão listados como polos de desenvolvimento. O Parque Tecnológico do Jaguaré é um dos dois projetos de parque tecnológico da prefeitura de São Paulo, o outro é o Parque Tecnológico de Itaquera, que pretende fazer parte do Sistema Paulista de Parques Tecnológicos (SPTec), criado pelo governo do Estado de São Paulo para dar apoio e suporte aos parques tecnológicos do estado.Ambos tem credenciais provisórias. $\mathrm{O}$ primeiro, com obra em andamento, pretende ser um polo tecnológico com ênfase em informação, fármacos, biotecnologia e nanotecnologia, e se articulará ao polo de ciência e tecnologia que estará à sua volta, a saber, aUniversidade de São Paulo (USP), o Instituto de Pesquisas Tecnológicas (IPT), o Instituto de Pesquisas Energéticas e Nucleares (Ipen) e o Instituto Butantan. Esse projeto procura, entre outras coisas, promover a expansão do eixo Marginal do Pinheiros em sua parte norte, pretendendo atrair empresas de alta tecnologia. $\mathrm{O}$ outro projeto marcado no mapa é o Parque de Eventos de São Paulo (Expo-SP) criado por meio do Projeto Estratégico de Intervenção Urbana (PEIU) na lei municipal $n^{\circ} 15.525$, de 9 de janeiro de 2012. 
No mesmo mapa, temos as intervenções urbanas na área central da cidade. A principal é, sem dúvida, o projeto Nova Luz, que a mais de trinta anos faz parte de planos de intervenção na prefeitura de São Paulo e nunca foi implementado. Hoje o projeto se caracteriza como uma concessão urbanística, a primeira na história da cidade. Outros dois projetos de revitalização indicados são o do Parque Dom Pedro II e do Vale do Anhangabaú.

Os mapas seguintes apresentam a rede atual de trens e metrôs da cidade e a rede projetada para o ano de 2025, com raio de 600 metros determinando a área de intervenção.

\section{Mapa 17 - Planos e projetos de intervenção urbana e rede de alta capacidade, 2012}

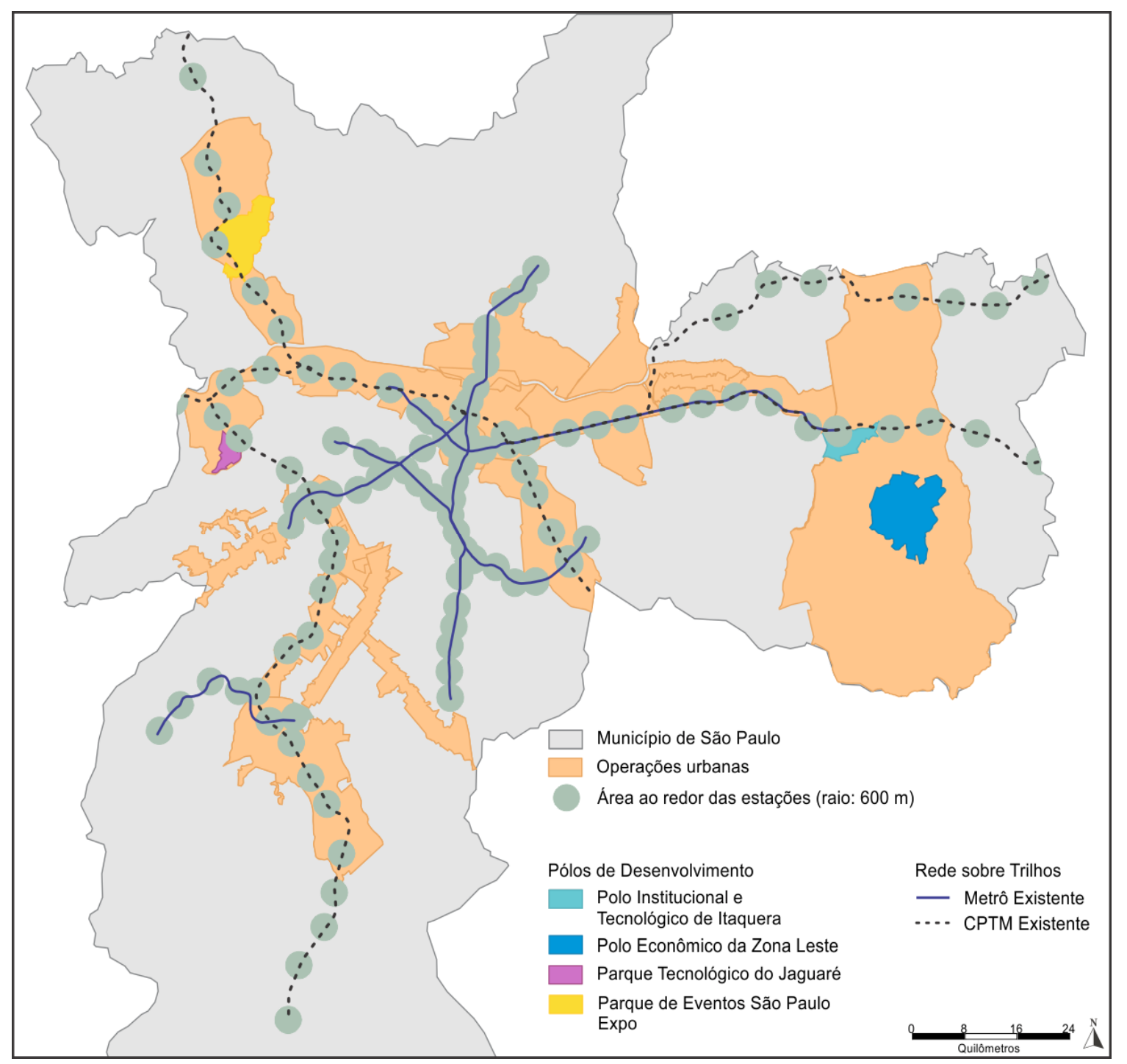

Fonte: Secretaria Municipal de Desenvolvimento Urbano - SMDU; Companhia do Metropolitano de São Paulo; Companhia Paulista de Trens Metropolitanos.

Elaboração: André de Freitas Gonçalves 
Quando pegamos essas áreas de intervenção, ou possíveis intervenções, e acrescentamos as áreas de intervenção urbana em torno das estações de trem e metrô, que são as mais favoráveis em termos de capacidade de infraestrutura de transporte para serem adensadas, isto é, que ali se apliquem os mecanismos urbanísticos para tal adensamento, podemos observar a extensão que se tem a dispor do poder público municipal em intervir na estrutura urbana da cidade.

\section{Mapa 18 - Planos e projetos de intervenção urbana e rede de alta capacidade até 2025}

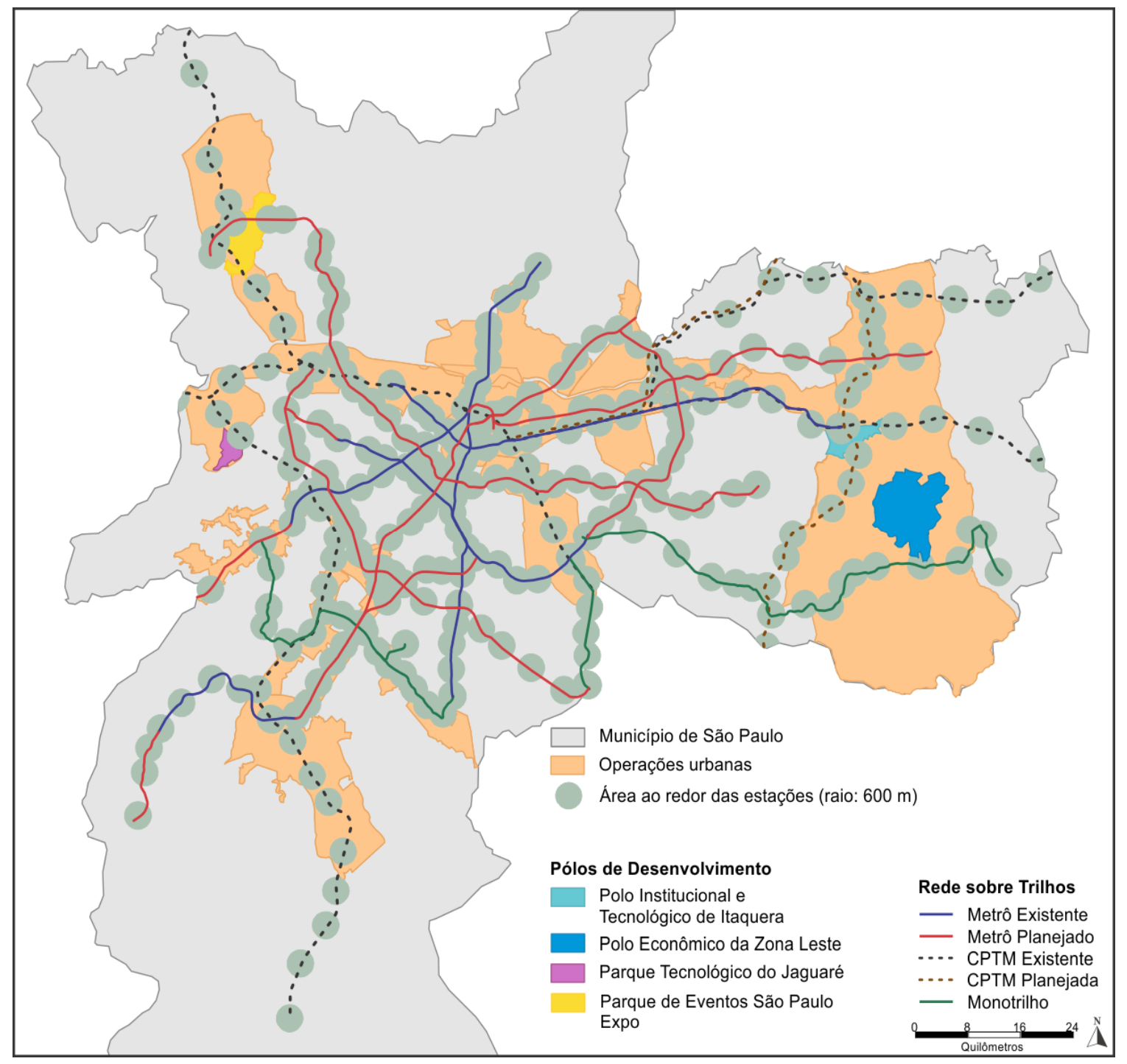

Fonte: Secretaria Municipal de Desenvolvimento Urbano - SMDU; Companhia do Metropolitano de São Paulo; Companhia Paulista de Trens Metropolitanos.

Elaboração: André de Freitas Gonçalves 
Observamos que, por meio das legislações urbanísticas é possível superar o coeficiente máximo permitido pela lei de zoneamento de 2004 em uma grande parcela da cidade, ficando assim a cargo da municipalidade escolher as áreas que receberão tais "privilégios". Outra característica que os mapas apresentam é a sobreposição de áreas atendidas por algum tipo de intervenção urbana, a que prevalece sobre as demais é a operação urbana.

Não é possível determinar se esses projetos serão efetivamente aplicados e não avaliaremos aqui sua pertinência e minúcias, contudo, é importante no nosso trabalho indicar que são projetos grandes e com potencial de transformação e reconfiguração da estrutura urbana, haja vista o resultado que tiveram as intervenções já executadas. Indicam uma direção que está sendo tomada no que tange ao desenvolvimento da cidade. Quando observamos a localização de tais projetos urbanos, notamos a busca pela descentralização da atividade econômica.

As intervenções na zona leste da cidade, há muito ambicionado pelo corpo técnico da prefeitura, vem se concretizando. Os projetos estão saindo do papel, a ligação da Avenida Jacu-Pêssego com Rodovia Ayrton Senna, ao norte, e com o Rodoanel ao sul, forjando um eixo que liga duas regiões produtoras- ao norte o município de Guarulhos e ao sul a região do ABC paulista - e todas com o porto de Santos, além de obras viárias de Faculdades e escolas técnicas estão em obras, um estádio de futebol, programando uma série de equipamentos que procuram promover um transporte na região, também, apoiado por um arcabouço normativo significativo. Tudo isso nos faz crer que a centralidade de Itaquera se fortaleça. Outros dois projetos, Expo-SP e Polo Tecnológico do Jaguaré podem também levar alterações importantes para as regiões oeste e norte da cidade, produzindo a expansão do eixo de desenvolvimento representado pela Marginal do Pinheiros, sentido norte, e criando um nova centralidade na região de Pirituba. Existe a perspectiva de criação da operação urbana Vila Sonia, em função da linha Amarela do Metrô, o que promoveria uma nova centralidade. Assim como as operações propostas em Lapa/Brás e Mooca/Vila Carioca procuram intensificar o uso misto, característico da região por se tratar de áreas tradicionais da indústria, o que pode acarretar grande interesse do mercado imobiliário.

Por outro lado, também existe o interesse em requalificar espaços tradicionais da cidade como a área do centro histórico. Até o presente, temos três grandes projetos de intervenção: o projeto Nova Luz que procura efetivar-se, o Parque Dom Pedro II e Vale Anhangabaú, que ainda estão em fase de projeto. Mesmo assim, o centro sempre termina por 
receber investimento público, demonstrando sua importância e relevância para o funcionamento da cidade.

\title{
Redes e fluxos
}

A cidade de São Paulo, com mais de 11 milhões de habitantes e uma Região Metropolitana de aproximadamente 20 milhões, sendo a principal metrópole do país, com status de cidade global, constitui-se como nó de diversas redes nacionais e internacionais de diferentes naturezas. Por meio delas, uma série de fluxos ganha sentido e as anima. Tais redes e fluxos ganham duas características importantes no período contemporâneo: a primeira é sua função de integrar o território, ligando pontos desconectados; a segunda característica é tornar o território mais fluído, isto é, tentar evitar empecilhos aos fluxos, permitindo sua aceleração, exigência contemporânea, para que assim se possam diminuir os custos e tempo do deslocamento. Essa condição é de fundamental importância para o entendimento do desenvolvimento econômico e social do período atual, quando:

\begin{abstract}
A divisão territorial do trabalho em escala crescentemente mundializada só é possível a partir de numerosas redes técnicas engendradas no bojo da expansão capitalista. Redes que se manifestam, sobretudo, em uma cada vez mais complexa rede urbana, cujos centros são, do ponto de vista funcional, simultaneamente especializados e hierarquizados, focos, portanto, de diversos fluxos. As cidades mundiais ou globais, sedes das grandes corporações multifuncionais e multilocalizadas, constituem, no final do século XX, os epicentros de numerosas, complexas e desiguais redes que tornaram a organização espacial caleidoscopicamente fragmentada e globalizada (CORRÊA, 1993, p. 31).
\end{abstract}

Essa configuração mais geral atinge diretamente à cidade de São Paulo e se reflete no cotidiano de seus habitantes de uma forma bem conhecida - tráfego urbano congestionado. Porém, o problema não pode ser tratado como uma simples questão de trânsito de veículos, e sim como crise de mobilidade urbana. A questão da forma de urbanização, da distribuição das atividades econômicas, da instalação de equipamentos geradores de tráfego, do uso efetivo do 
espaço urbano por seus moradores, entre outros tantos aspectos, devem ser relacionados na análise (ROLNIK, KLINTOWITZ, 2011; VASCONCELOS, 2000, 2012).

Nos dias de hoje, como podemos concluir, a questão de mobilidade urbana deve ser tratada, também, como questão de uso e ocupação do solo urbano quando se faz uma análise. Em termos técnicos, a acessibilidade está relacionada com a efetividade do sistema de transporte em conectar localidades espacialmente separadas e a mobilidade está associada com até que ponto um determinado indivíduo pode fazer uso do sistema. Para Cardoso (2005), a mobilidade é entendida como número médio de viagens diárias (todos os modos de transporte) realizado pelos habitantes de determinada área. A mobilidade da população de determinada área deve ser calculada dividindo-se o total de viagens realizado pelos habitantes da área em estudo (não importando onde esta viagem foi realizada) pelo número total de pessoas domiciliadas nesta mesma área. Essas definições guiarão nosso estudo.

Tarefa das mais complexas é equacionar todo o volume de variáveis que incidem na análise da mobilidade urbana de uma grande cidade. Em nosso trabalho, destacaremos a infraestrutura de transporte, a caracterização da rede de transportes públicos de média e alta capacidade - ônibus, metrô e trem - que cumprem papel fundamental no cotidiano das pessoas e empresas. Acreditamos ser fundamental tal investigação para que assim sejam identificados os pontos desconectados do território e aquelas áreas onde existem elevadas densidades de redes. Em conjunto serão caracterizados na sua situação atual e no plano de expansão da rede até 2025, definido no Plano Integrado de Transporte Urbano (Pitu). Por outro lado, destacaremos as principais estruturas viárias da cidade, procurando apontar os eixos de maior volume de tráfego, como esses foram idealizados ao longo da expansão da cidade, contextualizando a importância da centralidade de São Paulo no fluxo regional e nacional, como ponto de cruzamento entre as principais rodovias do país.

Uma vez identificada e caracterizada a rede de transporte viário principal, partiremos para a análise dos fluxos. Abordaremos o tema utilizando os dados da Pesquisa Origem e Destino da Companhia do Metropolitano de São Paulo (METRÔ), conhecida como pesquisa OD, nos anos de 1997 e 2007. Cabe lembrar que essa pesquisa é realizada de dez em dez anos. Por meio de uma regionalização, a cidade foi dividida em 16 áreas para nos ajudar a analisar o fluxo de viagens total de um ano para o outro, interno a cada área e sua relação com resto da cidade. A fim de identificar os pontos fortes de ligação regional e as localidades que atraem viagens demonstrando densidade de emprego e serviços gerais. 


\section{Infraestrutura de transportes}

O sistema de transporte público da cidade de São Paulo é composto principalmente por ônibus de média e baixa capacidade, uma vez que o sistema é subdividido em dois conjuntos: Subsistema Estrutural, onde as linhas são operadas por veículos de médio e grande porte (articulados, biarticulados e comuns), destinadas a atender altas demandas e integrar diversas regiões às áreas centrais da cidade. É a espinha dorsal do transporte coletivo, agindo nas principais vias da cidade; o outro conjunto é o Subsistema Local, que alimenta a malha estrutural e atende aos deslocamentos internos nos subcentros com linhas operadas por ônibus comuns e veículos de menor porte, como micro e miniônibus. A fiscalização, programação e planejamento do sistema são realizados pela empresa São Paulo Transportes (SPTrans), vinculada à Secretaria Municipal de Transportes que gerencia o sistema de ônibus. As atividades operacionais são realizadas por empresas terceirizadas, contratadas por meio de licitações públicas. Além das linhas, a prefeitura administra corredores e terminais de ônibus.

Como forma de complementar o sistema de transporte público da cidade, temos a iniciativa do governo do estado por meio da implantação do sistema de metrô que é operado pela Companhia do Metropolitano de São Paulo (METRÔ), e pela empresa ViaQuatro, que é a concessionária da Linha 4-Amarela do metrô. Há também o sistema de trens metropolitanos, operado pela Companhia Paulista de Trens Metropolitanos (CPTM) e, por fim, um sistema de ônibus intermunicipal metropolitano, operado pela Empresa Metropolitana de Transportes Urbanos de São Paulo S.A. (EMTU) que, também, administra terminais e corredores de ônibus.

Como podemos observar, a figura seguinte representa a distribuição da demanda por transporte coletivo na Região Metropolitana de São Paulo. Há uma divisão por competência, na qual o Município de São Paulo, por meio do sistema de ônibus, participa atendendo $55 \%$ da demanda e os outros $45 \%$ é suprido pelo governo do estado por meio do sistema de metrô $(21 \%)^{48}$, trem metropolitano (13\%) e ônibus metropolitano (11\%). Como é possível perceber, a importância do sistema de ônibus é enorme para cidade e, por vezes, ele é

\footnotetext{
${ }^{48}$ Aqui consideramos o sistema de metrô como um todo, isto é, tanto o operado pela Companhia do Metropolitano de São Paulo (METRÔ) e a empresa ViaQuatro concessionária da Linha 4-Amarela do metrô.
} 
deixado de lado, como se fosse irrelevante, como se não fosse necessário investir na sua melhoria como um todo, incluindo terminais, corredores e articulação dos ônibus pela cidade.

Figura 8 - Demanda por transporte coletivo, Região Metropolitana de São Paulo, 2011

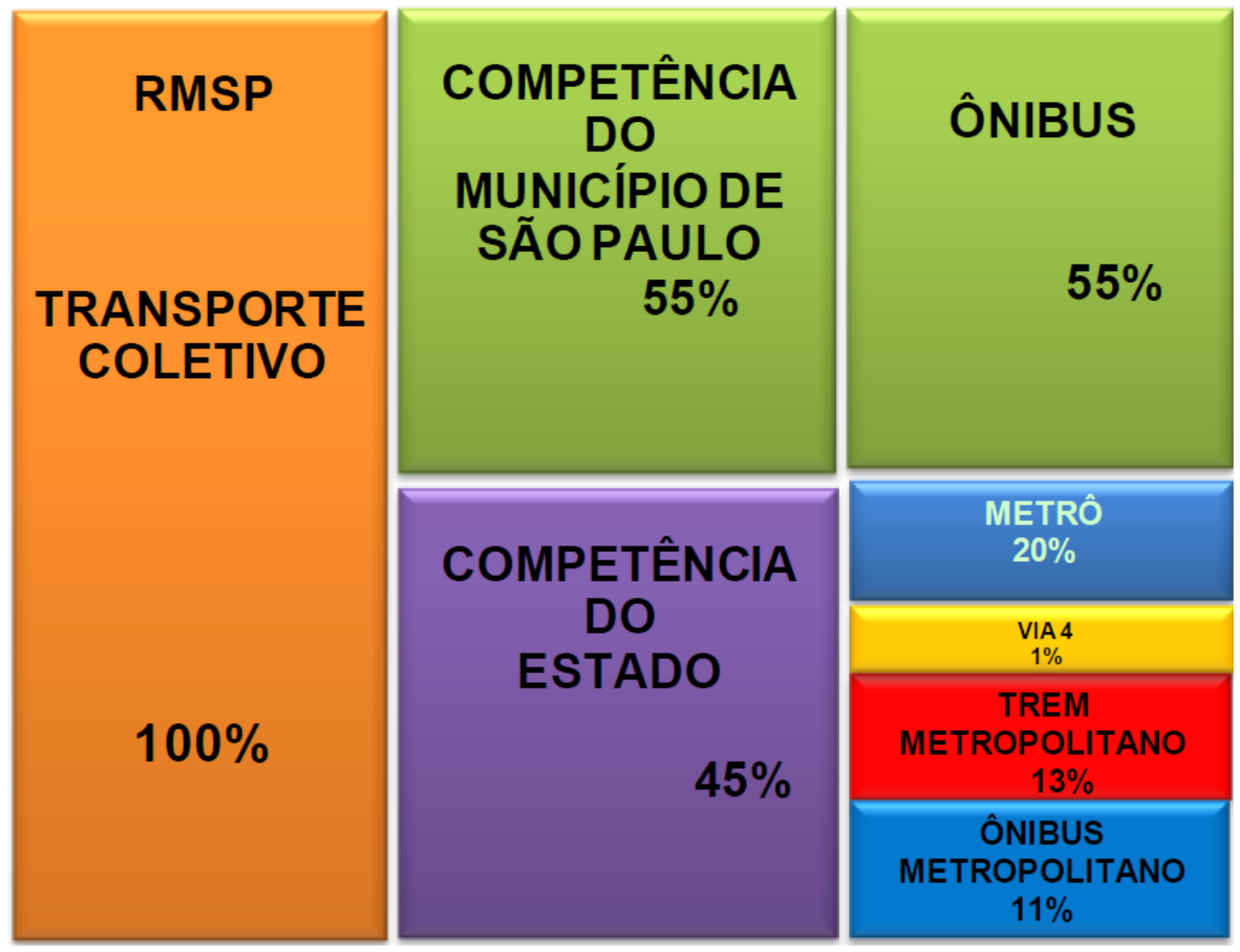

Fonte: Secretaria Estadual dos Transportes Metropolitanos. Coordenadoria de Transporte Coletivo (CTC). Monitoramento da demanda 2008/2011.

Mesmo com pouco investimento, o sistema de ônibus recebe preferencialmente a atenção da prefeitura de São Paulo quando se trata de transporte público, por ser menos oneroso e mais compatível com o orçamento municipal. Por se tratar de uma cidade do tamanho de São Paulo, a prefeitura deveria participar do investimento em outros sistemas, como o Metrô e Monotrilho. Nos últimos anos, a administração municipal tem realizado investimentos, por meio de transferência para o governo do estado, na expansão do Metrô por exemplo. Porém, é uma ação esporádica, sem compromisso legal ou administrativo.

A cidade de São Paulo conta com aproximadamente 15 mil ônibus, 1.350 linhas, com 31 terminais e aproximadamente 126 quilômetros de corredores de ônibus dentro do 
sistema administrado pela prefeitura. Com uma demanda crescente, o sistema de ônibus em 2011 transportou 2.941 milhões de passageiros, como podemos verificar no gráfico seguinte: Isso representa cerca de $10 \%$ a mais de passageiros do que há cinco anos. No ano de 2004, a SPTrans implantou o Bilhete Único, que possibilita um controle estatístico mais apurado do registro da demanda. O Bilhete Único, que é um bilhete eletrônico que pode ser carregado e utilizado no sistema de ônibus, metrô e trem. Com ele, o usuário pode tomar mais de uma condução no sistema, sem ter que pagar novamente, podendo realizar até três transferências e, caso faça a integração com o metrô ou trem, paga meia passagem. Tal programa possibilitou um maior controle administrativo e, para o usuário, maior mobilidade dentro da cidade, com custo menor. Também possibilitou uma maior integração com o sistema de metrô e trens que fazem parte do sistema controlado pelo governo do estado.

\section{Gráfico 5 - Demanda de passageiros nos ônibus municipais, Município de São Paulo, 2002 a 2011}

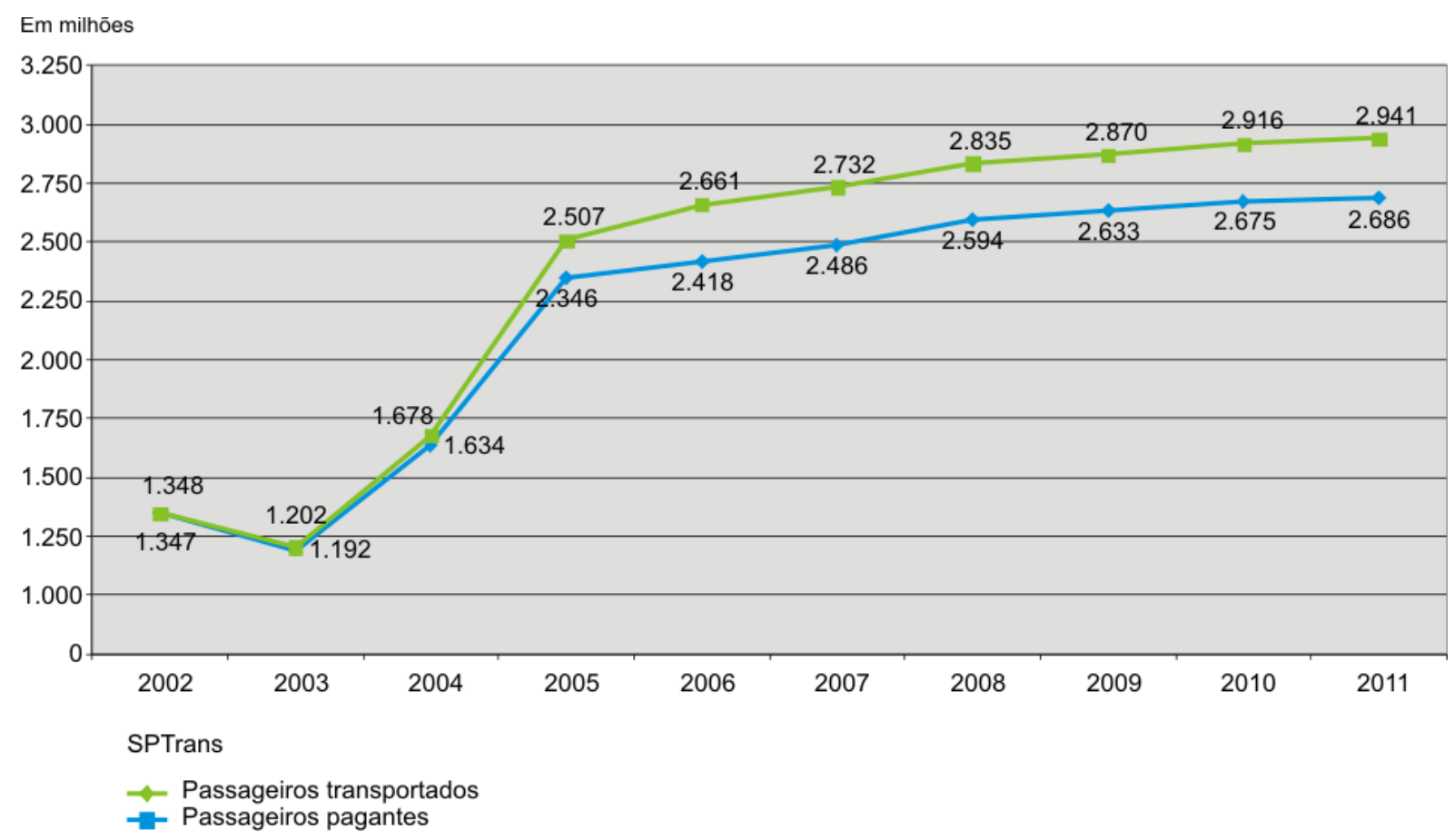

Fonte: Secretaria Estadual dos Transportes Metropolitanos. Coordenadoria de Transporte Coletivo (CTC). Monitoramento da demanda 2008/2011.

Elaboração: André de Freitas Gonçalves

O sistema de transporte coletivo na cidade tem o controle partilhado entre o poder público municipal e o estadual, conforme já apresentamos. Isso poderia ser considerado como 
um fator negativo na gestão do transporte, mas não é o que acontece de fato, pois o sistema é integrado e se completa na maior parte dos casos satisfatoriamente. Em grande medida, isso acontece em função de visão que os órgãos públicos envolvidos têm de como tratar a questão do transporte coletivo, pensando a partir da gestão metropolitana do transporte. O governo do estado administra a questão de transporte coletivo em cada região metropolitana, gerenciado por uma secretaria própria, a Secretaria dos Transportes Metropolitanos, que tem como subordinados as empresas EMTU, CPTM e METRÔ que operam o sistema.

Por iniciativa do estado, é criado em 1997 o primeiro Programa Integrado de Transportes Urbanos (Pitu) da Região Metropolitana de São Paulo (RMSP), conhecido como PITU 2020, por ter como horizonte de ação o ano de 2020. Tinha como objetivo pensar a metrópole do futuro e fazer uma série de propostas sobre implantação de redes de transporte. Depois do ano 2000, com a divulgação dos dados do Censo Demográfico do IBGE e com as alterações no campo jurídico da política urbana em função da promulgação do Estatuto das Cidades, o grupo se viu na obrigação de construir uma nova proposta, tendo em vista que as alterações já eram esperadas e constava na própria metodologia do Plano um processo de planejamento permanente e de revisões periódicas, incorporando novos dados da realidade e reajustando as projeções. Assim se cria o PITU 2025, com proposições concernentes com a realidade que ali se encontrava. A elaboração de um Plano tão ambicioso passa por diversas frentes de trabalho e procura abordar questões que diretamente envolvem o tema de transporte, como o uso e ocupação do solo, e políticas habitacionais para condicionar um desenvolvimento urbano seletivo com a distribuição das atividades econômicas de forma mais equânime pela cidade, visando à elaboração de propostas de infraestrutura.

No mapa seguinte, Sistema de transporte coletivo - 2012, apresentamos o cenário atual e algumas propostas de implantação de rede que estão no PITU 2025, bem como outras que já fazem parte de alterações definidas posteriormente ao fechamento do documento, e estão previstas nos planos das empresas que operam o sistema. Por exemplo, o METRÔ apresenta uma proposta de implantação de novas vias com prazo até 2014. No mapa, está indicada pela cor vermelha e prazo definido busca atender ao evento da Copa do Mundo de futebol. 
Mapa 19 - Sistema de transporte coletivo, 2012

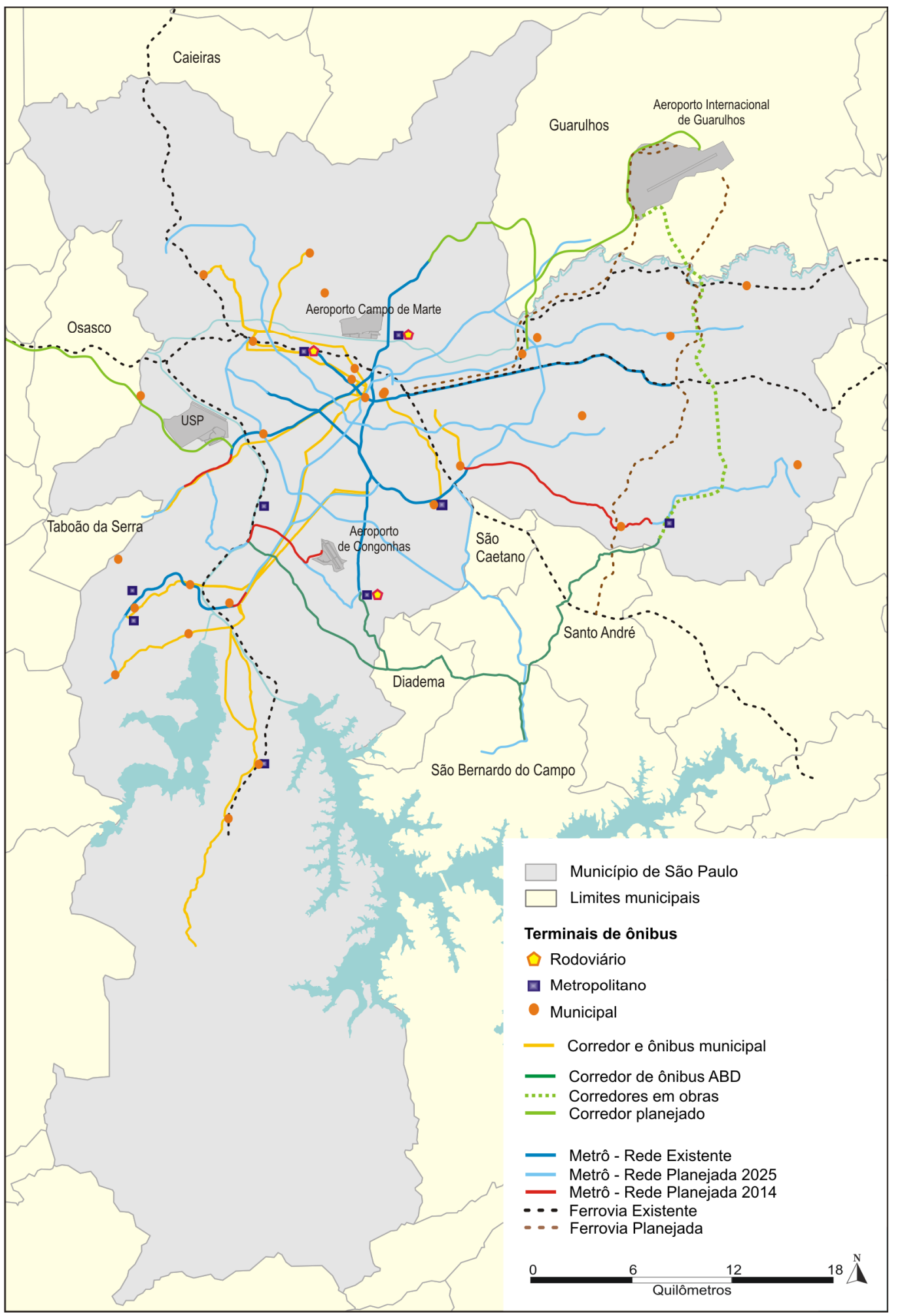

Fonte: Companhia Paulista de Trens Metropolitanos (CPTM); Empresa Metropolitana de Transportes Urbanos de São Paulo S.A. (EMTU); Companhia do Metropolitano de São Paulo (METRÔ); São Paulo Transportes (SPTrans)

Elaboração: André de Freitas Gonçalves 
É importante destacar no caso do sistema metroviário uma nova concepção de implantação de redes. A extensão da linha-2 do Metrô, que passa pela Avenida Paulista e vai sentido zona leste da cidade, passando por Tamanduateí e chegando à Vila Prudente, terá a partir daí, em direção a São Mateus e posteriormente a Cidade Tiradentes, um sistema de média capacidade, onde se implantará o monotrilho. Além da vantagem de ter um custo de implantação bem abaixo do metrô, sua execução é mais rápida, podendo assim acelerar o processo de construção de redes de média capacidade e atender uma demanda reprimida. Essa estratégia também será utilizada na linha 17-Ouro do Metrô, ainda planejada, que ligará a estação Jabaquara da linha-1 do Metrô à linha-4 Amarela, passando pelo aeroporto de Congonhas, arredores da Avenida Luiz Carlos Berrini e bairro do Morumbi. Para o ano de 2014, está prevista sua construção entre o aeroporto e a estação Morumbi da CPTM, próxima à Avenida Luiz Carlos Berrini. A linha planejada, ainda sem previsão de entrega, que ligará o município de São Bernardo do Campo à estação Tamanduateí da CPTM, também será um monotrilho. Para o ano 2014, temos a conclusão da linha-4 amarela, chegando até a estação Vila Sônia, e a inauguração de mais uma estação da linha-5 lilás, a Adolfo Pinheiros.

Nos planos da CPTM, com o sistema ferroviário, está a construção da linha-13 Jade, ligando o Brás com o Aeroporto Internacional de Guarulhos até 2014. Ao seu redor, assim como no projeto Expresso Aeroporto, que ligaria a estação Barra Funda ou a estação da Luz com o aeroporto, ocorreram grandes mudanças nos últimos anos por diversas razões. A começar pela indecisão do projeto federal do Trem de Alta Velocidade (TAV) que ligaria São Paulo ao Rio de Janeiro, os projetos do governo de São Paulo usariam a mesma infraestrutura do TAV. Outro fator negativo que atrapalhou a ligação do maior aeroporto do país com a maior cidade do país por meio de um transporte de alta capacidade foi a incerteza da ampliação do aeroporto, prometida pelo governo federal. Isso afastou as empresas do projeto Expresso Aeroporto, que acabou sendo arquivado. Agora a CPTM consegue tirar do papel o projeto da linha-13 que fará tal ligação. Outro projeto indicado no mapa é o Veículo Leve sobre Trilhos (VLT), que ligará o município de Santo André, na região do ABC, ao Aeroporto Internacional de Guarulhos, passando pela zona leste da cidade de São Paulo. Contudo, esse projeto está em fase de estudo e negociação, com um prazo preliminar de conclusão em 2021.

Quando olhamos para o sistema de média-baixa capacidade, desempenhado pelos corredores de ônibus, observamos que não existem projetos para cidade de São Paulo na instância do poder público municipal. Isso se deve à ideia, por parte da prefeitura, que a cidade precisa de sistemas de alta capacidade e, por isso, investe no metrô. Como já foi dito, a 
prefeitura, depois de muitas décadas, voltou a investir no metrô, porém sem compromisso legal ou administrativo, a não ser aquele assumido pelo prefeito ainda em campanha. Por falar nisso, para que seja cumprida uma promessa de campanha, que justamente era investir em corredores de ônibus, a prefeitura no último ano de mandato do atual governo resolve investir em corredor de ônibus municipal, de forma que ninguém sabe ao certo o que será implantado e onde, até o presente momento. Foram implantados pequenos trechos de corredores, totalizando pouco mais de 11 quilômetros.

Porém, quando olhamos para o mapa, observamos os corredores de ônibus intermunicipal ou metropolitano, operados pela EMTU ${ }^{49}$, em obras ou apenas planejados, resultado do Programa de Corredores Metropolitanos de Transporte Coletivo de Média Capacidade da Região Metropolitana de São Paulo (PCM), elaborado em 2010. Observamos, por exemplo, na zona oeste de São Paulo, o corredor em obras Itapevi-São Paulo, que ligará a estação Butantã da linha-4 amarela do Metrô com Itapevi, município da região metropolitana, passando por importantes municípios como Osasco e Barueri, onde se localiza o importante centro de negócios Alphaville; Na zona norte de São Paulo, está em construção o corredor Guarulhos-São Paulo, que ligará a estação Tucuruvi da linha-1 do metrô com o terminal metropolitano Taboão (Guarulhos) ao lado do aeroporto internacional de Guarulhos. Esse corredor tem uma extensão que também está em construção e se ligará com o terminal municipal Aricanduva. Na zona leste da cidade, há em planejamento o corredor Perimetral Leste, que seguirá a Avenida Jacu-Pêssego, cortando a região de norte a sul, ligando dois corredores importantes: o já consolidado corredor ABD, que liga o terminal metropolitano de São Mateus na zona leste de São Paulo, com a estação Jabaquara da linha-1 do metrô e com a estação Morumbi da CPTM, passando pela região do ABC, e com o corredor Guarulhos-São Paulo que está em obras.

O plano de expansão de corredores metropolitanos da EMTU fará aumentar a demanda por esse serviço e equilibrará o sistema de transportes como um todo. Trata-se de ligações importantes que, associadas com outras iniciativas, podem trazer desenvolvimento e qualidade de vida para os moradores vizinhos. A demanda registrada por esse tipo de serviço apresenta crescimento nos últimos anos. Como mostra o gráfico seguinte, o serviço comum da EMTU alcançou 446 milhões de passageiros transportados na Região Metropolitana de São Paulo no ano de 2011 e 83 milhões só no corredor de ônibus ABD.

\footnotetext{
${ }^{49}$ Importante dizer que no corredor de ônibus ABD, que passa por Santo André, São Bernardo do Campo e Diadema, com extensão até a estação Morumbi da CPTM, a SPTrans pode e faz uso com ônibus municipais que por ali passam.
} 
Gráfico 6 - Demanda de passageiros de ônibus intermunicipal, Região Metropolitana de São Paulo, 2002 a 2011

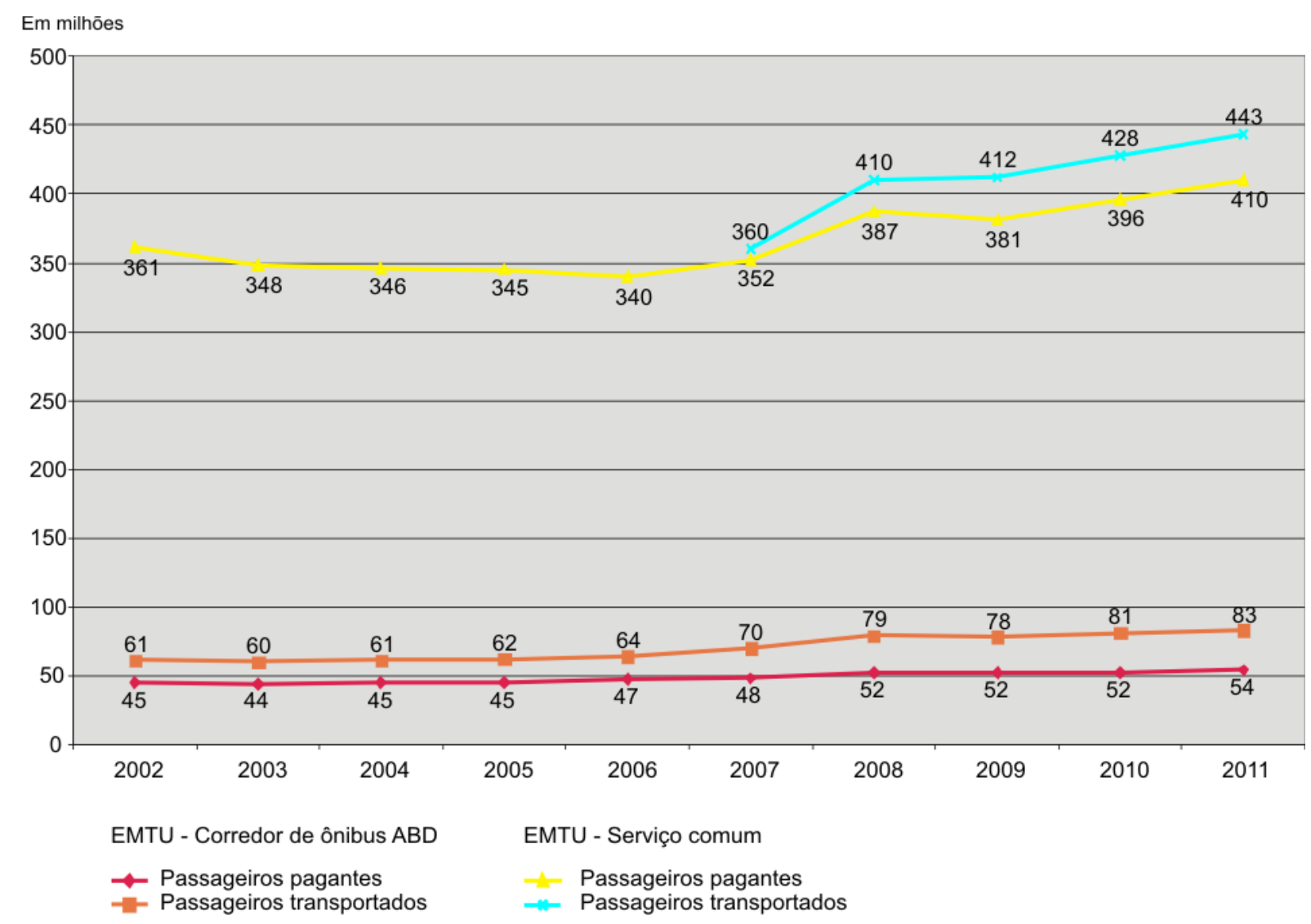

Fonte: Secretaria Estadual dos Transportes Metropolitanos. Coordenadoria de Transporte Coletivo (CTC). Monitoramento da demanda 2008/2011.

A CPTM, companhia de trens, administra uma malha que ultrapassa o limite da Região Metropolitana de São Paulo, chegando até o município de Jundiaí, com extensão total de linhas operacionais de 258,6 quilômetros, média por dia útil de 2.319 milhões de passageiros transportados. Dividido por linha, temos: Linha-7 (Luz -Jundiaí) com 391.272, linha-8 (Júlio Preste - Itapevi) 430.564, linha-9 (Osasco - Grajaú) 364.486, linha-10 (Brás Rio Grande da Serra) 366.155, linha-11 (Luz - Estudantes) 558.771, e linha-12 (Brás Calmon Viana) 208.717. No ano de 2011, foram 700,2 milhões de passageiros transportados. É o que verificamos no gráfico seguinte, com a demanda de passageiros da CPTM e do Metrô, que em comparação tem cerca de 70 quilômetros de trilho, média por dia útil de 2,74 milhões de passageiros transportados e com máxima diária de 3,14 milhões registrados no ano de 2011 que, no total, registrou 1,087 bilhões de passageiros transportados. Se compararmos os valores totais dos dois sistemas, veremos que o Metrô transporta muito mais passageiros do que os trens, contudo se calcularmos as taxas de crescimento anual, veremos que a CPTM tem 
taxas de crescimento de $9 \%$ ao ano, o que faz mais do que dobrar o número de usuários atendidos nos últimos nove anos, crescendo aproximadamente $120 \%$, passando de 319 milhões de passageiros transportados para 700. Enquanto o Metrô tem taxas anuais de crescimento por volta de 4,4\%, registrando um crescimento de aproximadamente 50\%, passando de 732 milhões de passageiros transportados para 1.087. Fica claro o brutal crescimento de passageiros no sistema ferroviário e metroviário que ocorreu nos últimos anos, o que não corresponde com a disponibilização da oferta. Para tentar amenizar problemas advindos dessa enorme massa de usuários, a CPTM tem nos últimos anos encurtado o tempo entre um trem e outro, tendo como meta alcançar o intervalo de 3 minutos. Esse é o máximo que o sistema suportaria. O Metrô, por outro lado, procura recuperar os anos sem investimento, construindo poucos quilômetros de rede e está em obras em pelo menos três linhas diferentes.

\section{Gráfico 7 - Demanda de passageiros no metrô e trem, Município de São Paulo, 2002 a 2011}

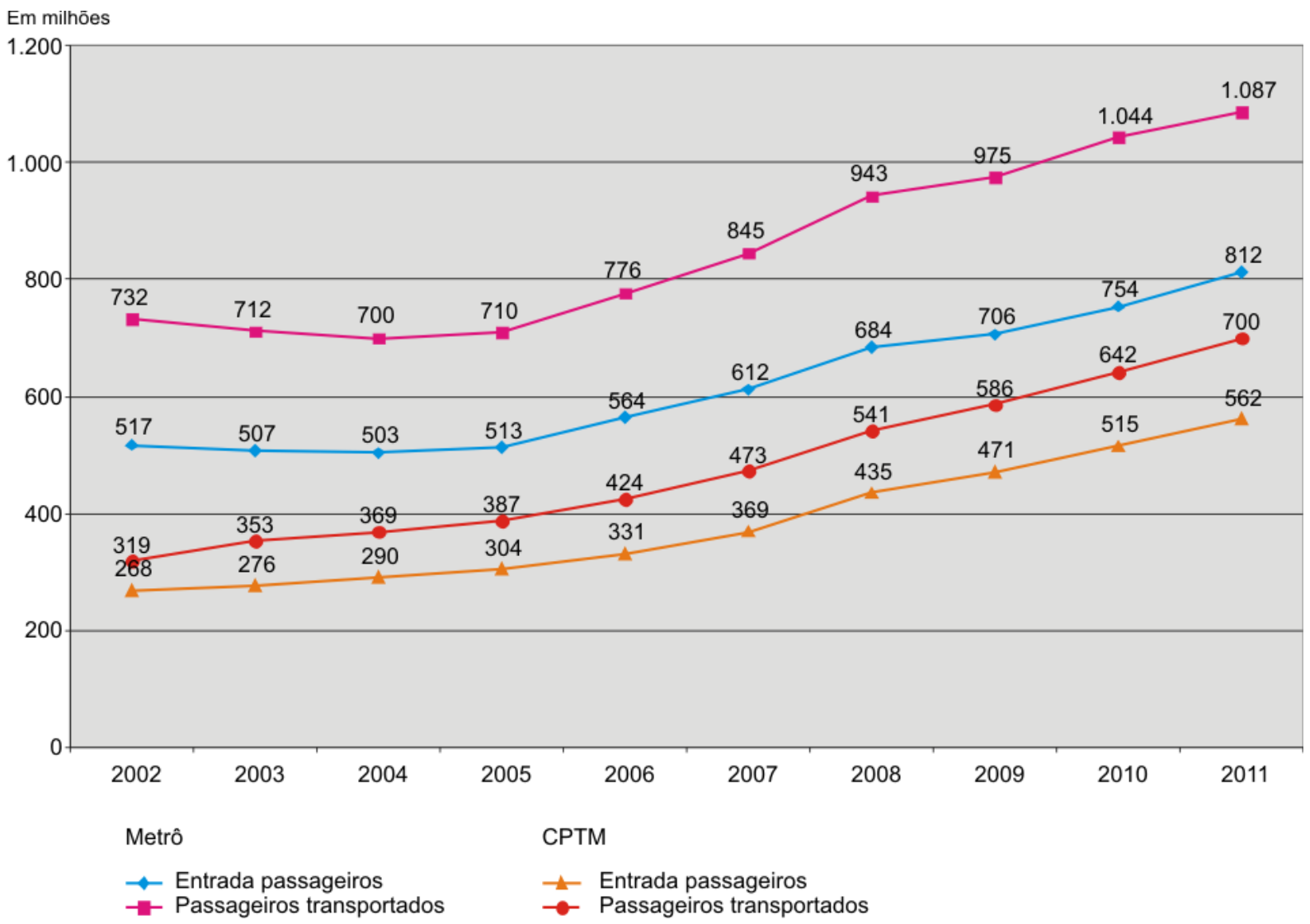

Fonte: Secretaria Estadual dos Transportes Metropolitanos. Coordenadoria de Transporte Coletivo (CTC). Monitoramento da demanda 2008/2011. 
Está nos planos do Metrô a construção de mais 30 km até 2014 e mais 90 km são previstos para 2018. A meta é chegar a 200 quilômetros construídos, porém entendemos que no meio dessa conta está o monotrilho, que é um sistema mais barato, mais rápido de ser feito e tem menor capacidade de transporte. Entre a inauguração do metrô, em 1974 e 1984, 24,7 km de linhas passaram a operar, uma média de construção de 2,47 km por ano. Na década seguinte, entre 1984 e 1994, foram 18,7 km de novas linhas, com média de 1,87 km por ano. Entre 1994 e 2004, foram apenas 1,42 km de metrô por ano no período. Verificamos uma decaída no decorrer das décadas, e registrando média histórica, de 1974 a 2006, de 1,88km de metrô por ano. Nos últimos anos, o governo do estado conseguiu aumentar a média para 2,82 km por ano. Mesmo assim, a tarefa de implantar $21 \mathrm{~km}$ de metrô em dois anos, considerando o retrospecto, não é fácil, ainda mais sabendo que de 1995 até 2012, ou seja, 17 anos, foram instalados $25 \mathrm{~km}$ de metrô. Mesmo sabendo que o metrô sozinho não resolve o problema de transporte e muito menos o de mobilidade, a cidade precisa de uma rede maior. Se compararmos a de outras grandes cidades, verificamos tanto o nosso atraso na extensão da rede quanto à superlotação do nosso sistema metroviário, conforme o gráfico seguinte.

Tabela 5 - Rede de metrô em grandes cidades, 2012

\begin{tabular}{l|r|r|r|r}
\hline \multicolumn{1}{c|}{ Cidades } & $\begin{array}{c}\text { Extensão em } \\
\text { Km }\end{array}$ & $\begin{array}{c}\text { Número de } \\
\text { estações }\end{array}$ & $\begin{array}{c}\text { Passageiros por } \\
\text { dia em milhões }\end{array}$ & $\begin{array}{c}\text { Passageiro } \\
\text { por km }{ }^{(1)}\end{array}$ \\
\hline Xangai & 423 & 279 & 3,56 & 3,07 \\
Londres & 402 & 270 & 3,00 & 2,72 \\
Nova York & 368 & 468 & 4,33 & 4,29 \\
Moscou & 306 & 185 & 6,55 & 7,81 \\
Tóquio & 304 & 290 & 8,70 & 10,45 \\
Madri & 286 & 282 & 1,78 & 2,27 \\
Paris & 215 & 381 & 4,00 & 6,79 \\
Cidade do México & 201 & 175 & 3,88 & 7,05 \\
São Paulo & 74 & 64 & 2,90 & 14,30 \\
\hline
\end{tabular}

Fonte: Folha de São Paulo ${ }^{50}$.

(1) Número de passageiros transportados no ano por extensão do metrô.

Nota: Para determinar o número de passageiros por dia em milhões em São Paulo foi utilizado o número de passageiros no ano de 2011 dividido pelo número de dias.

\footnotetext{
${ }^{50}$ Disponível em: http://www1.folha.uol.com.br/turismo/1058521-linhas-de-metro-pelo-mundo-levammodernidade-e-conservam-historia.shtml Acesso em: 15/05/2012.
} 
A distribuição do número de passageiros na rede metroviária é representada no mapa seguinte, que apresenta as conexões com a rede de trens, terminais municipais, metropolitanos, corredores de ônibus municipais, terminais rodoviários e pontos de parada de ônibus fretados. Todos são equipamentos que completam o sistema, possibilitando integrações entre os diferentes meios de transporte. O normal é o usuário utilizar mais de um meio para fazer suas atividades cotidianas e, portanto, colocamos no mapa o maior número de equipamentos de transferência possíveis. Observamos que as estações de metrô estão representadas por círculos proporcionais ao volume de passageiros que entram em cada estação $^{51}$, a de maior número é a estação da Barra Funda com média nos dias úteis de 205 mil passageiros, seguida por Luz com 132 mil, Consolação com 116 mil e Brás com 112 mil, todas em áreas mais centrais da cidade, onde se localizam os principais centros de comércio, serviço e de empregos. Importante destacar que as três principais estações de trens em número de entrada de passageiros são Brás com 164 mil, Luz com 149 mil e Barra Funda com 142 mil, repetindo a mesma centralidade. Outros pontos merecem destaque, como o extremo norte, leste e sul, representados respectivamente pela estação Tucuruvi com entrada de passageiros por volta de 60 mil, Itaquera com 95 mil e Jabaquara com 89 mil. Fica clara a importância desses terminais de entrada no sistema metroviário, pois são neles que correm o fluxo vizinho realizado por meio de outros meios de transporte. Por exemplo, a estação Jabaquara tem um terminal rodoviário e um terminal metropolitano, este último conectado ao corredor de ônibus ABD. Tratam-se, assim, de redes e pontos que alimentam a rede do Metrô, e isso acontece em diferentes partes do sistema. A estação da Barra Funda é um conjunto de diferentes meios de transporte: existe metrô, trem, terminal rodoviário, terminal metropolitano, terminal municipal e ponto de parada de ônibus fretado. Nesse local, fluem uma série de fluxos. Boa parte da zona noroeste da cidade tem como ponto de partida para o restante da cidade a Barra Funda.

Outro aspecto interessante é a disposição dos pontos de paradas de ônibus fretados, em volta do centro consolidado da cidade, com paradas próximas às estações da CPTM na Marginal do Pinheiros em torno da Avenida Luiz Carlos Berrini e em pontos próximos a estações de metrô como a estação Imigrante, Sacomã, Vila Madalena, Sumaré, Brás e Barra Funda. Antes a distribuição desses usuários era realizada na rua ou avenida do

\footnotetext{
${ }^{51}$ Em média de dias úteis. As estações da linha-4 amarela não fazem parte dos registros da Companhia do Metropolitano de São Paulo.
} 
trabalho. Agora, por meio de uma proibição, os fretados não podem circular livremente pela cidade, tendo local específico de parada e assim alimentando o sistema sobre trilhos.

\section{Mapa 20 - Volume de passageiros, 2011}

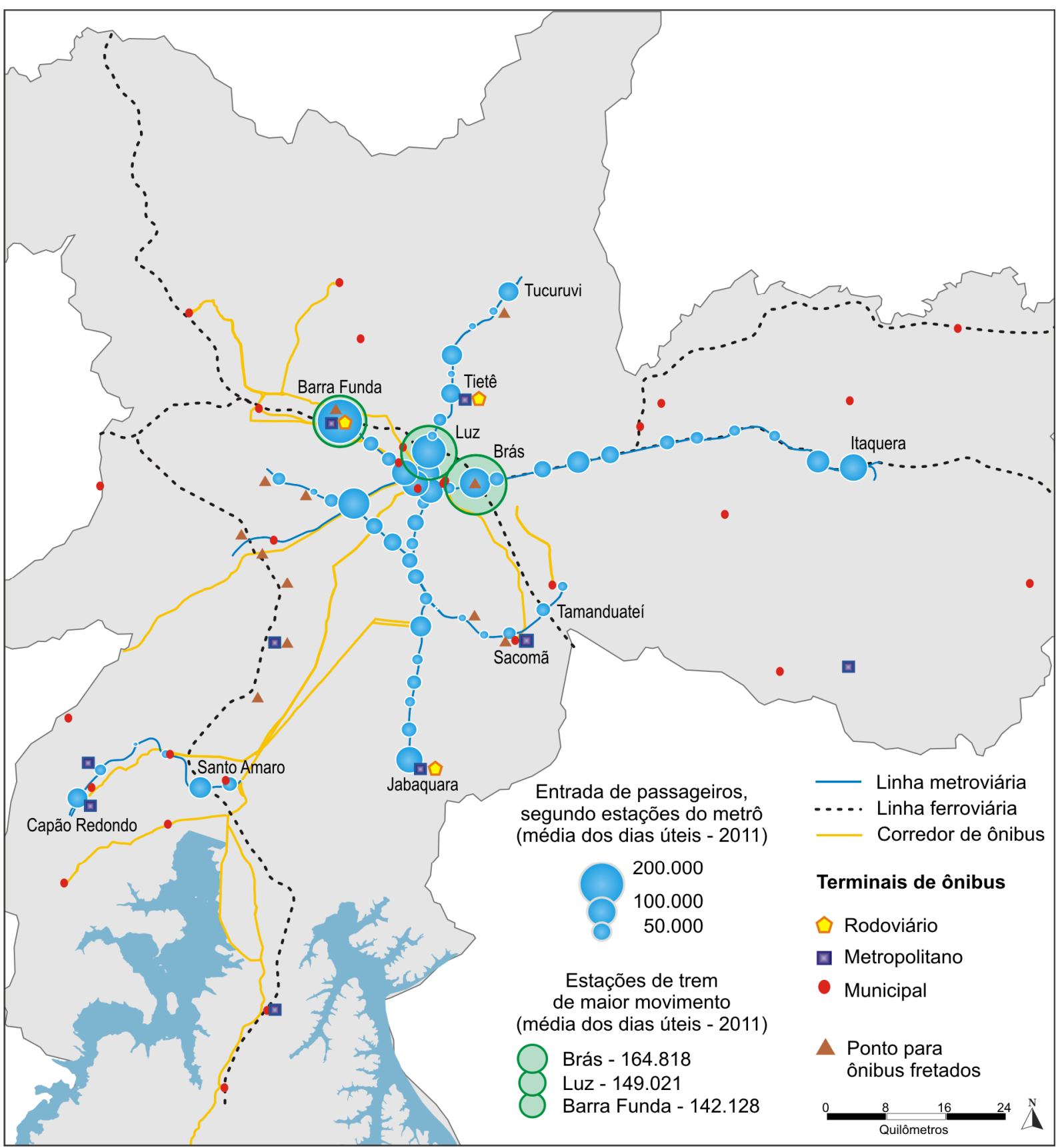

Fonte: Companhia Paulista de Trens Metropolitanos (CPTM); Companhia do Metropolitano de São Paulo (METRÔ); São Paulo Transportes (SPTrans)

Elaboração: André de Freitas Gonçalves

A alimentação do sistema metroviário se dá de outra forma também muito difundida, onde o usuário se desloca com seu automóvel até uma estação de metrô um pouco distante do centro consolidado, pois este sempre está congestionado. Ele deixa seu carro em 
um estacionamento e continua sua viagem de metrô. Outra motivação que faz o usuário aderir a essa estratégia é o rodízio municipal de veículos. A cada dia útil da semana, um conjunto de carros classificados pelo final de sua placa é proibido de circular no centro expandido da cidade entre os horários de pico, das 7 às 10 horas e das 17 às 20 horas. Essa lei foi criada em 1997 com o intuito de melhorar a condição ambiental da cidade e reduzir o congestionamento da cidade nos horários de maior movimento. $\mathrm{O}$ centro expandido que podemos ver no mapa seguinte, chamado de Anel do Centro Expandido, abrange um perímetro na parte mais consolidada da cidade e é onde se concentra a atividade econômica.

Ainda no mapa que apresenta os anéis viários e a estrutura rodoviária da cidade, observamos que essa lógica de organização do território está bem consolidada e segue a tradição iniciada nos anos 1920 com a formulação o primeiro anél viário, elaborado por engenheiros da prefeitura, composto pelas vias Líbero Badaró, Boa Vista, Praça da Sé e Largo São Francisco (VASCONCELlOS, 2000). Logo depois, em 1930, é lançado o Plano de Avenidas de Prestes Maia, estrutura viária radio-concêntrica (composta por vias radiais e perimetrais), limitando o zoneamento a poucas áreas da cidade e promovendo a expansão urbana. Também orientou a política de crescimento da cidade durante as décadas seguintes. Esse modelo de anéis viários marca a estrutura de circulação e mobilidade da cidade (ROLNIK, KLINTOWITZ, 2012). Ver na figura esquema teórico do Plano de Avenidas.

\section{Figura 9 - Esquema teórico do Plano de Avenidas}

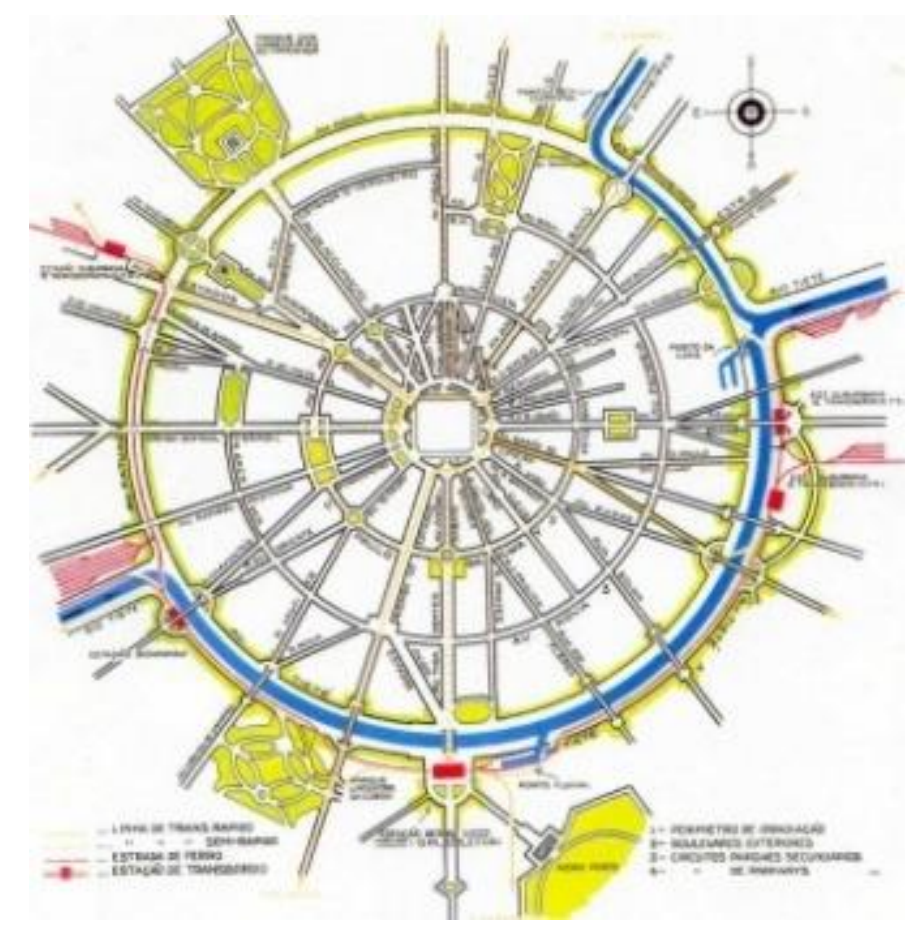

Fonte: Prestes Maia, 1930. In: ANELLI, Renato Luiz Sobral, 2007. 
Mapa 21 - Anéis viários e estrutura rodoviária, 2012

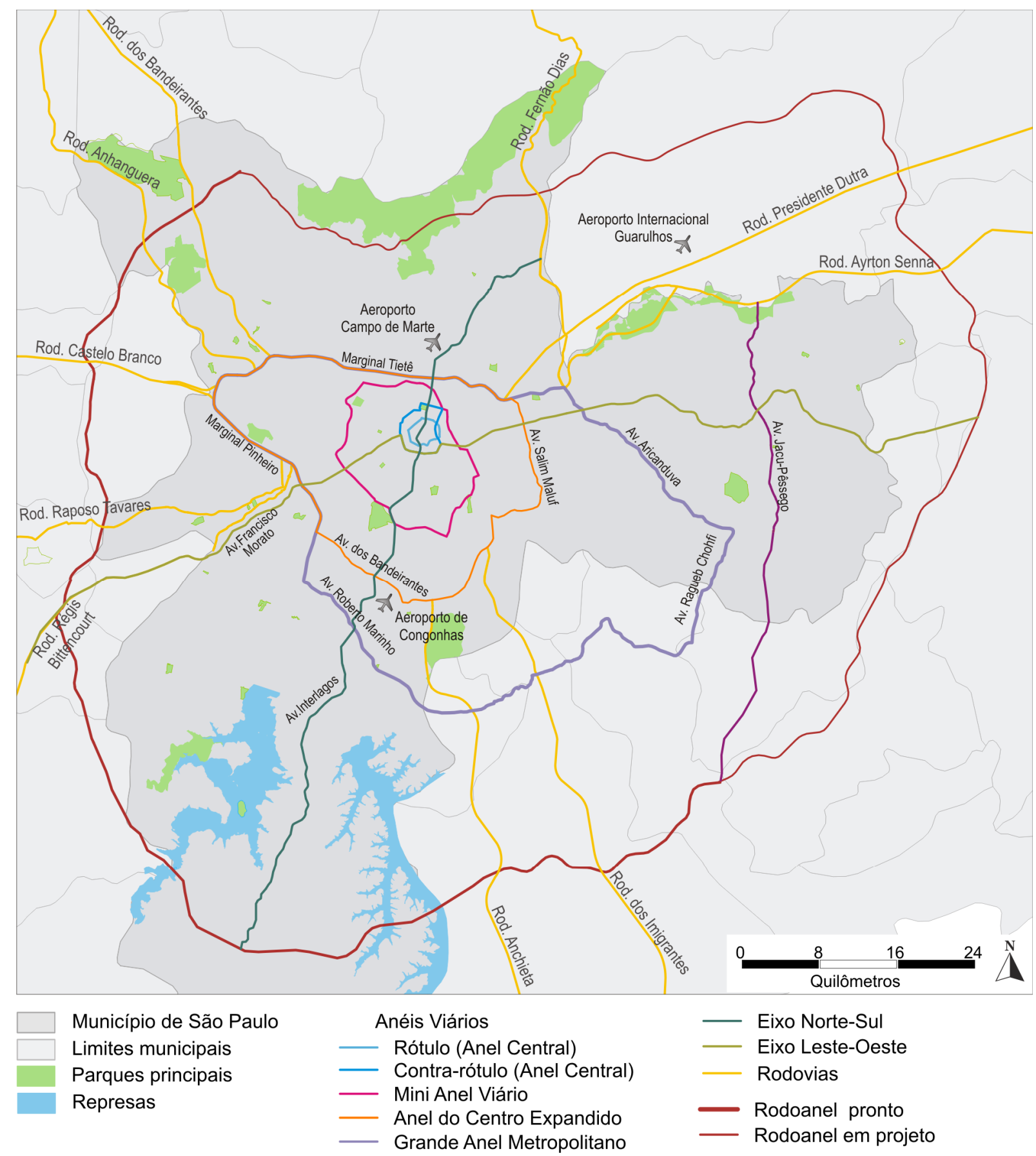

Fonte: Secretaria Estadual de Logística e Transportes.

Elaboração: André de Freitas Gonçalves

Em 1949, a prefeitura elabora o Plano de Melhoramentos Públicos, com a participação de Robert Moses, responsável pelos planos de "rodovias urbanas" aplicadas em Nova York. Com esse novo plano, não foi alterada a importância da estrutura radioconcêntrica vigente, mas foi identificado o impacto que a rede de rodovias estaduais tinha sobre a cidade de São Paulo que sempre foi na história da formação do estado o ponto de 
encontro, como podemos ver no mapa anterior. Portanto, o plano propõe a utilização das Marginais do Tietê e Pinheiros para absorver o fluxo, recebendo o tráfego das rodovias (ROLNIK, KLINTOWITZ, 2012). Essa função nos dias de hoje é partilhada com outro anel viário, o Rodoanel, que possui as partes oeste e sul concluídas. Esse anel faz a ligação do interior do estado, principalmente por meio das rodovias Anhanguera e Bandeirantes, com o porto de Santos. Também liga os estados do sul do país por meio da rodovia Régis Bittencourt. O trecho leste do Rodoanel está em obras e a função de conectar o porto de Santos com o Vale do Paraíba e o Rio de Janeiro é executada pela Avenida Jacu Pêssego, ligada à rodovia Ayrton Senna, ao norte, e em sua extensão ao sul se estendendo pela Avenida Papa João XXIII no município de Mauá, que por sua vez se liga ao trecho sul do Rodoanel, permitindo acesso quase sem barreiras até as rodovias sentido litoral e ao porto de Santos. Essa estrutura desempenha um papel de grande importância para a economia brasileira, porque estabelece ligação rodoviária entre as regiões Norte e Sul do país e direciona os fluxos de tráfego de carga para o Porto de Santos. O projeto do Rodoanel foi motivo de preocupação para grande parte da sociedade por ocupar áreas verdes e de mananciais, a exemplo dos anéis viários de décadas passadas. Como forma de compensação ambiental pelo impacto provocado na construção do Rodoanel, foram criados vários parques naturais e áreas de preservação junto às represas na zona sul da cidade. Importante destacar que a gestão de um conflito como esse sempre tem de ser realizada considerando a prevervação das águas e do verde como necessária ao bom funcionamento do própria sistema urbano (THERY-MELLO, 2012).

De forma geral, a demanda por transporte coletivo vem crescendo fortemente em todos os meios na região metropolitana. Apesar da diminuição das taxas de crescimento populacional, a pressão sobre o sistema de transporte é crescente, em parte pelo aumento da mobilidade da população, condição econômica favorável, e por outra pela necessiadade de se optar por novas estratégias de deslocamento a fim de superar o imobilismo provocado pelo trânsito crescente em toda a cidade. Pelo lado da oferta, passamos por um momento de grandes investimentos no sistema sobre trilhos e, como observamos, a demanda não para de crescer. Isso significa que existe uma demanda reprimida, não atendida, em grandes áreas periféricas da cidade de São Paulo e sua região metropolitana. As obras que estão em andamento e a rede planejada, se aplicada, poderá redistribuir a demanda no sentido de equilibrar o sistema e incentivar novos núcleos de atividade econômica. 


\section{Mobilidade urbana}

A mobilidade no Município de São Paulo e na sua região metropolitana, medida pelo índice de mobilidade ${ }^{52}$, decresceu de 1,53 viagens motorizadas por habitante , em 1977, para 1,32, em 1987, e para 1,23, em 1997, apresentando um pequeno crescimento em 2007, quando passa a registrar o índice de 1,29. Esse é um indicador importante porque reflete o nível socioeconômico da população, assim como as condições de circulação existentes no município. A queda da mobilidade pode ser uma decorrência do desemprego e a diminuição da renda, dois fatores que levam à redução dos deslocamentos realizados.

A divisão modal das viagens é a maior causa dos problemas de transporte e trânsito na Região Metropolitana de São Paulo e das dificuldades de circulação existentes. A tabela da evolução da divisão modal das viagens motorizadas mostra um crescimento da proporção de viagens feitas pelo modo individual em comparação com as que se realizam pelo modo coletivo, antes da última pesquisa Origem e Destino do Metrô em 2007. De início em 1967, a relação era de 31,9\% para o modo individual e $68,1 \%$ para o modo coletivo e em 2007, passa a ser de 44,7\% para o modo individual e 55,3\%. Porém, é importante destacar que o modo coletivo consegue reverter à tendência de queda na participação das viagens diárias, voltando a patamares registrados no ano de 1987. Reflete na taxa de motorização que permaneceu estável em comparação à pesquisa anterior, também contendo a tendência histórica que era o aumento no número de automóveis em relação à população. Isso aconteceu porque as taxas de crescimento da população e automóveis, registrados na pesquisa, se mantiveram próximas.

Tabela 6 - Evolução da Divisão Modal e da Taxa de Motorização, Região Metropolitana de São Paulo

\begin{tabular}{|c|c|c|c|c|c|c|c|c|c|c|}
\hline \multicolumn{11}{|c|}{ (em milhares) } \\
\hline & 1967 & $\%$ & 1977 & $\%$ & 1987 & $\%$ & 1997 & $\%$ & 2007 & $\%$ \\
\hline População & 7.097 & & 10.273 & & 14.248 & & 16.792 & & 19.535 & \\
\hline Viagens diárias internas motorizadas & 7.187 & 100 & 15.999 & 100 & 18.750 & 100 & 20.620 & 100 & 25.168 & 100 \\
\hline Viagens diárias internas de coletivo & 4.894 & 68,1 & 9.759 & 61 & 10.455 & 55,8 & 10.473 & 50,8 & 13.913 & 55,3 \\
\hline Viagens diárias internas de auto & 2.293 & 31,9 & 6.240 & 39 & 8.295 & 44,2 & 10.147 & 49,2 & 11.255 & 44,7 \\
\hline Taxa de motorização (1) & 70 & & 135 & & 141 & & 184 & & 184 & \\
\hline
\end{tabular}

Fonte: Companhia do Metropolitano de São Paulo/ Metrô-SP

(1) Taxa de Motorização: Número de automóveis por 1000 habitantes.

\footnotetext{
${ }^{52}$ Índice de Mobilidade: Número de viagens por habitante.
} 
O que tais números apontam, bem como os dados apresentados na primeira parte do trabalho a respeito do aumento da demanda no sistema de transporte coletivo, é que as pessoas passaram a utilizar pouco menos o transporte individual. Entre 1997 e 2007, a mobilidade por modo coletivo, passa de 0,62 para 0,71 viagens por pessoa, enquanto que o índice de mobilidade por modo individual passa de 0,59 para 0,58 viagens por habitante.

Ainda assim, a metrópole de São Paulo, com cerca de 25 milhões de viagens motorizadas e realizadas diariamente, em 2007, sofre com esta divisão modal. Verifica-se que as viagens motorizadas utilizam esmagadoramente o sistema viário, pois, além das viagens realizadas por automóveis e do transporte de carga, $75 \%$ das viagens coletivas são realizadas por ônibus. As consequências são as externalidades negativas geradas pelo trânsito, que apresentou, em 2011, 108 km de lentidão média no trânsito no pico da tarde. Isso representa um custo adicional para o transporte de produtos e insumos que onera diretamente a produção, assim como aumenta os custos dos deslocamentos para toda a população, e provoca ainda uma queda na qualidade de vida.

Os tempos médios de viagem têm sido sempre significativamente maiores para as viagens realizadas por modos coletivos do que as de automóvel, para todas as faixas de renda. O que mudou nas últimas pesquisas é que o tempo médio de viagem aumentou de modo significativo para ambos. O tempo médio no modo coletivo em 1987 era de 60 minutos, passou para 61 em 1997 e para 69 minutos em 2007. Já o tempo médio no modo individual era 24 minutos em 1987, passou para 27 em 1997, e alcançou 31 minutos em 2007. Comparativamente, o tempo médio de ambos os modos cresceram proporcionais, contudo o tempo médio do modo coletivo é mais que o dobro do modo individual. Isso reforça a percepção favorável ao automóvel por parte da população e contribui para o agravamento da divisão modal das viagens.

Para que possamos analisar os fluxos de viagens pela cidade, foi necessário selecionar uma forma de agregação dos dados das pesquisas OD de 1997 e 2007. As opções disponíveis não satisfaziam nossa necessidade e não eram as melhores opções para escala de análise com que trabalhamos. Ora eram muito desagregadas (Distritos), ora muito amplas (Grandes Regiões). Logo, foi necessário criar um nível intermediário. Forjamos 16 regiões na cidade para realizar uma análise comparativa do fluxo de viagens registrado nas pesquisas Origem e Destino de 1997 e 2007. O mapa seguinte demonstra a regionalização que procurou manter a divisão das grandes regiões. Isso foi possível nitidamente na zona norte, onde mantivemos as regiões conhecidas como Norte 1 e Norte 2, aqui denominadas como Pirituba 
e Santana. A região central aqui denominada Sé é a própria subprefeitura e região da Sé historicamente definida. Sempre que possível, foi mantido algum tipo de referência às divisões administrativas da prefeitura. Essa regionalização é compatível com a divisão distrital. Outro critério para definição das áreas foi o aspecto infraestrutura de transporte, densidade populacional e de atividade econômica, o que motivou, por exemplo, a separação da região denominada Pinheiros e Vila Mariana, e de Santo Amaro e Grajaú.

\section{Mapa 22 - Regionalização de São Paulo}

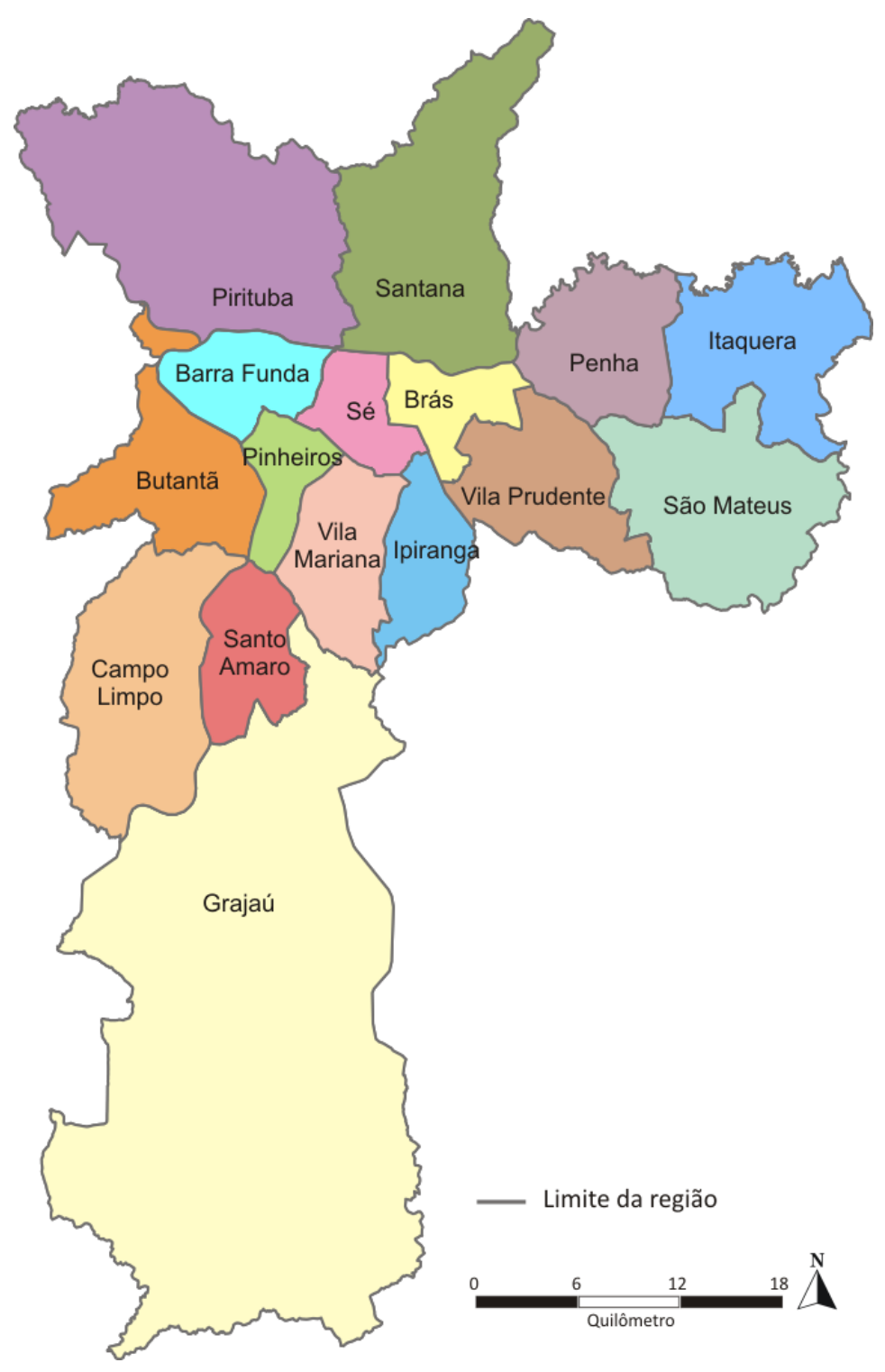

Base cartográfica: Secretaria Municipal de Desenvolvimento Urbano - SMDU/Dipro.

Elaboração: André de Freitas Gonçalves 
Como podemos observar no gráfico seguinte, as características demográficas e econômicas das regiões sintetizam de maneira geral o quadro da cidade de São Paulo. Temos áreas na periferia com elevadas taxas de crescimento demográfico e com grande contingente populacional, ao passo que em áreas centrais, os valores tendem a ser menores em número de habitantes e apresentam taxas de crescimento demográfico negativas ${ }^{53}$. Isso considerando o resultado obtido na Pesquisa OD de 2007. Por outro lado, temos áreas centrais que concentram atividade econômica, apresentando elevadas taxas de crescimento do número de emprego, enquanto áreas periféricas têm baixo desempenho e acumulam menor volume de empregos.

\section{Gráfico 8 - População e emprego, Regiões do Município de São Paulo, 1997/2007}

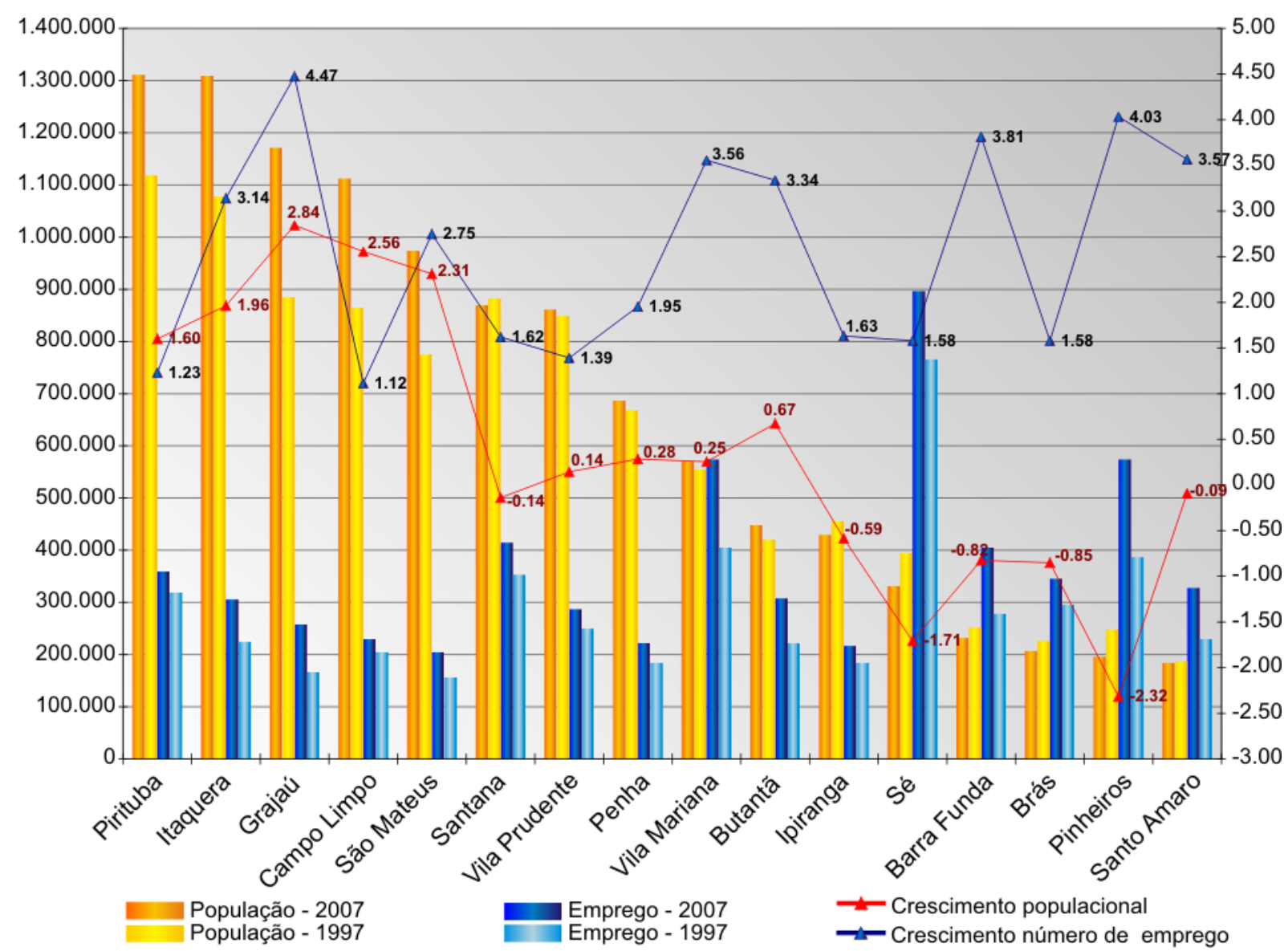

Fonte: IBGE. Censo Demográfico, 2000; Sempla/Dipro - Estimativa populacional, 2007.

Elaboração: André de Freitas Gonçalve

\footnotetext{
${ }^{53}$ Como demonstramos no primeiro capítulo deste trabalho, as taxas de crescimento demográfico para áreas mais centrais tiveram resultados positivos, considerando os dados do Censo Demográfico do IBGE, quebrando uma tendência iniciada fortemente em 1980.
} 
Analisando a produção de viagens no município de São Paulo, podemos identificar aquelas regiões que terminam por produzir mais viagens externas que internas, como verificamos no gráfico seguinte que apresenta os resultados para o ano de 1997. Ao contabilizarmos as viagens produzidas naquele local, somamos as viagens de retorno, isto é, das pessoas que não moram naquela localidade com as viagens de seus moradores. Desse modo, conseguimos verificar de onde as pessoas saem e para onde elas vão, assim como medir o peso das viagens internas à região. Entre as regiões que mais atraem pessoas, estão a Sé, Vila Mariana e Pinheiros, conformando o núcleo mais dinâmico e consolidado da cidade. As duas últimas regiões apresentam os maiores índices de mobilidade ${ }^{54}$, tanto total quanto motorizada.

\section{Gráfico 9 - Viagens produzidas, Regiões do Município de São Paulo, 1997}

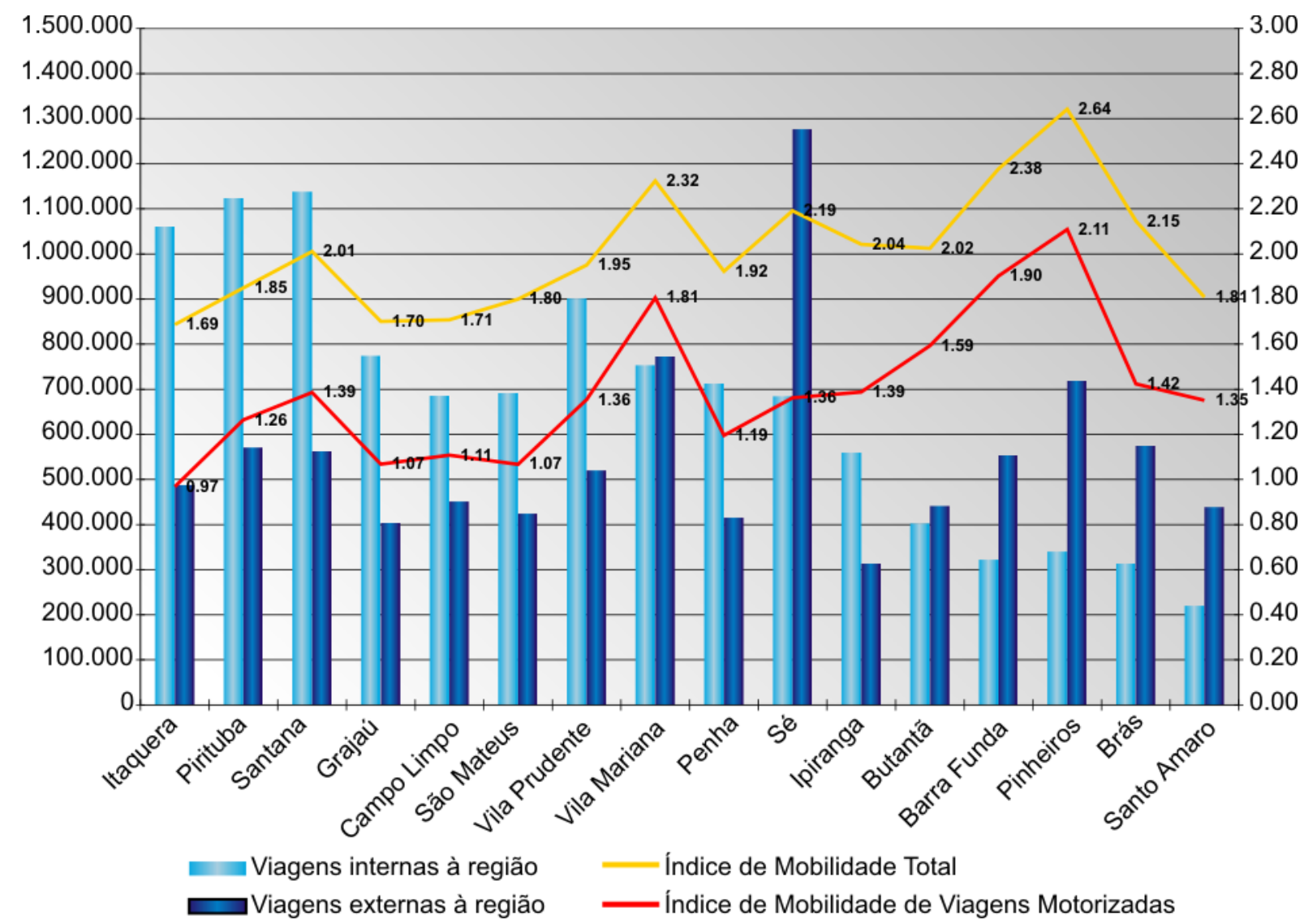

Fonte: Companhia do Metropolitano de São Paulo - METRÔ. Pesquisa Origem e Destino, 1997. Elaboração: André de Freitas Gonçalves

\footnotetext{
${ }^{54} \mathrm{O}$ índice de mobilidade total ou motorizada é calculado com o número de habitantes residentes pelo número de viagens que esses moradores fizeram, e não pelo número de viagens realizadas na região.
} 
Em comparação com os dados de 2007, no gráfico seguinte, observamos um aumento significativo no número de viagens internas de duas regiões, Itaquera e Pirituba, que inclusive ultrapassam o número de viagens produzidas da região da Sé. Por outro lado, as regiões que atraem mais viagens continuaram as mesmas, Sé, Vila Mariana e Pinheiros, com um destaque importante para região da Barra Funda que cresceu em volume de viagens e consegue ultrapassar a região de Pinheiros, passando a ter o mais alto índice de mobilidade entre as 16 regiões. Entre os índices mais baixos, nos dois anos apresentados, estão os de Itaquera, São Mateus e Campo Limpo. O índice de Grajaú é o quarto mais baixo em 2007, melhorando a posição que tinha em 1997 quando estava igualado com São Mateus. Isso é reflexo da elevada taxa de crescimento anual do número de viagens produzidas por Grajaú, a maior entre as regiões, registrando $5,75 \%$.

\section{Gráfico 10 - Viagens produzidas, Regiões do Município de São Paulo, 2007}

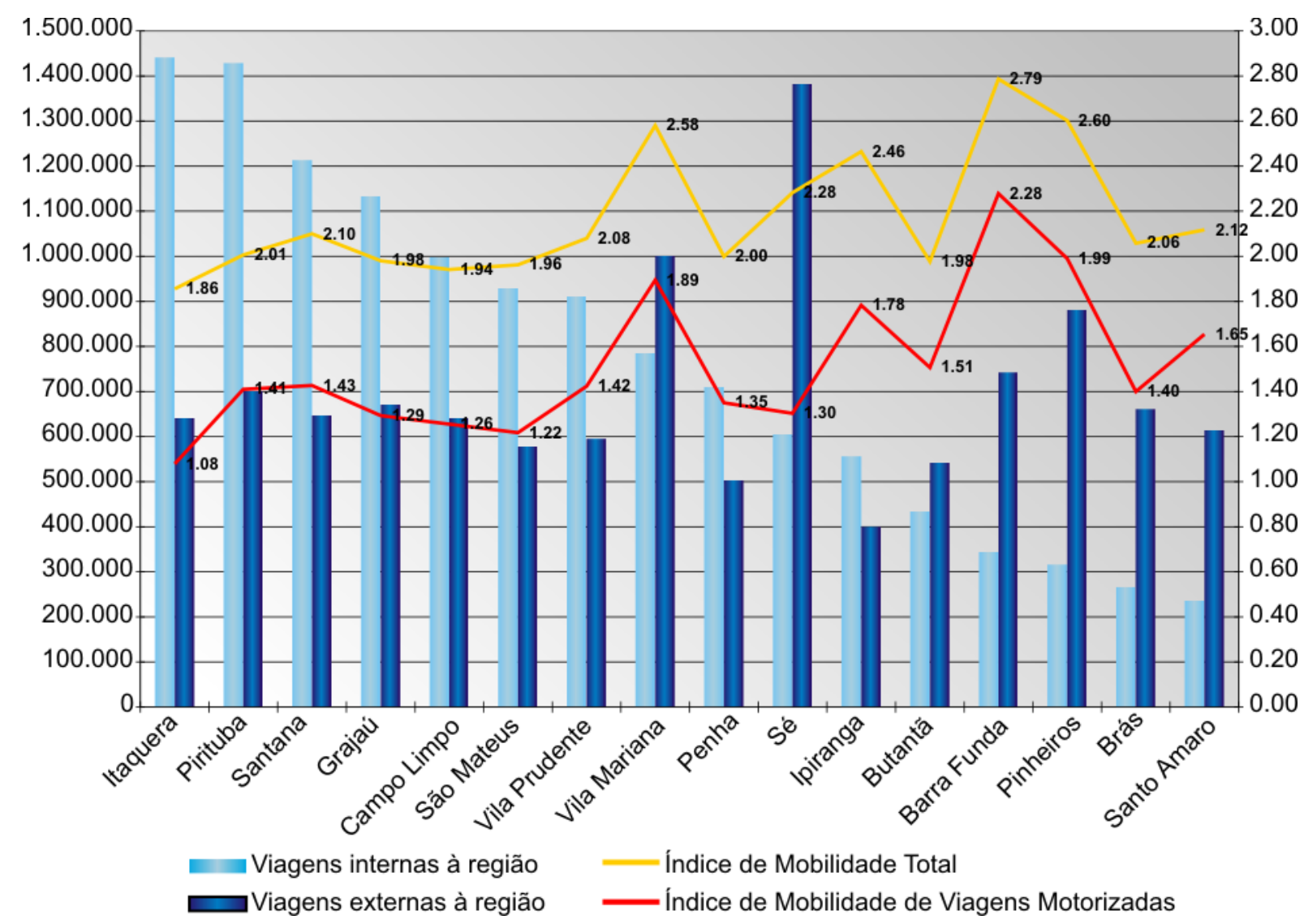

Fonte: Companhia do Metropolitano de São Paulo - METRÔ. Pesquisa Origem e Destino, 2007. Elaboração: André de Freitas Gonçalves

Não podemos deixar de notar movimentos mais sutis apresentados pelos dois gráficos, pois é preciso identificar as transformações em curso em diferentes pontos da cidade. 
Por intermédio do índice de mobilidade, podemos verificar possíveis alterações na dinâmica econômica e social de determinado local, assim como pelo número de viagens produzidas. Portanto, cabe indicar a variação auferida na região de Santo Amaro, que passa de um índice de mobilidade de 1,81 em 1997 para 2,12 em 2007, subindo de posição, passando de $12^{\circ}$ lugar em 1997, para $6^{\circ}$ lugar em 2007. Levando em consideração que a população se mantém estável durante o período, vale dizer que houve melhora efetiva na qualidade da mobilidade urbana dessa região. O inverso aconteceu com a região do Butantã, zona oeste da cidade, que passou de um índice de mobilidade de 2,02 em 1997 e passa a 1,93 em 2007. Alterações mais sutis são identificadas nas regiões da Penha e Vila Prudente, áreas da zona leste mais próximas do centro dinâmico da cidade. Seus índices de mobilidade cresceram e seguiram a tendência dos demais.

Essa caracterização nos serve para melhor entender os fluxos que alimentam as redes de transporte coletivo e as vias da cidade. Com diferentes motivações, as pessoas passam a circular na cidade, gerando um volume enorme de viagens, animando as redes e a vida urbana. É este movimento entre regiões da cidade que passaremos a analisar nos mapas seguintes (fluxo total de viagens por regiões da cidade), comparando os anos de 1997 e 2007. O objetivo é determinar os fluxos de maior volume a fim de expressar, por meio da representação cartográfica, quais centros são mais visados, que caminhos são mais utilizados e consequentemente os meios de alcançá-los.

O mapa que representa os fluxos de 1997 aponta, como era de se esperar, para onde estão as centralidades hegemônicas da cidade - Sé, Pinheiros e Vila Mariana - região mais consolidada e dinâmica que concentra o maior número de empregos e serviços de modo geral. Importante dizer que se trata de fluxo total de viagens, não somente aquelas motivadas por questões de emprego. Com destaque para região da Sé, para onde fluem fluxos de todos os lugares da cidade; também, para as regiões de Pirituba e Santana, mostrando grande incidência de deslocamentos entre os vizinhos, estimulados pela proximidade de serviços, universidades, hospitais, escolas, mas também por empregos, lembrando que essas regiões integram a parte norte da Marginal do Tietê; e outro destaque para Santo Amaro que sempre foi referência, tanto como centro de serviços quanto de emprego, para bairros próximos das regiões de Campo Limpo e Grajaú. 
Mapa 23 - Fluxo total de viagens por Regiões de São Paulo, 1997

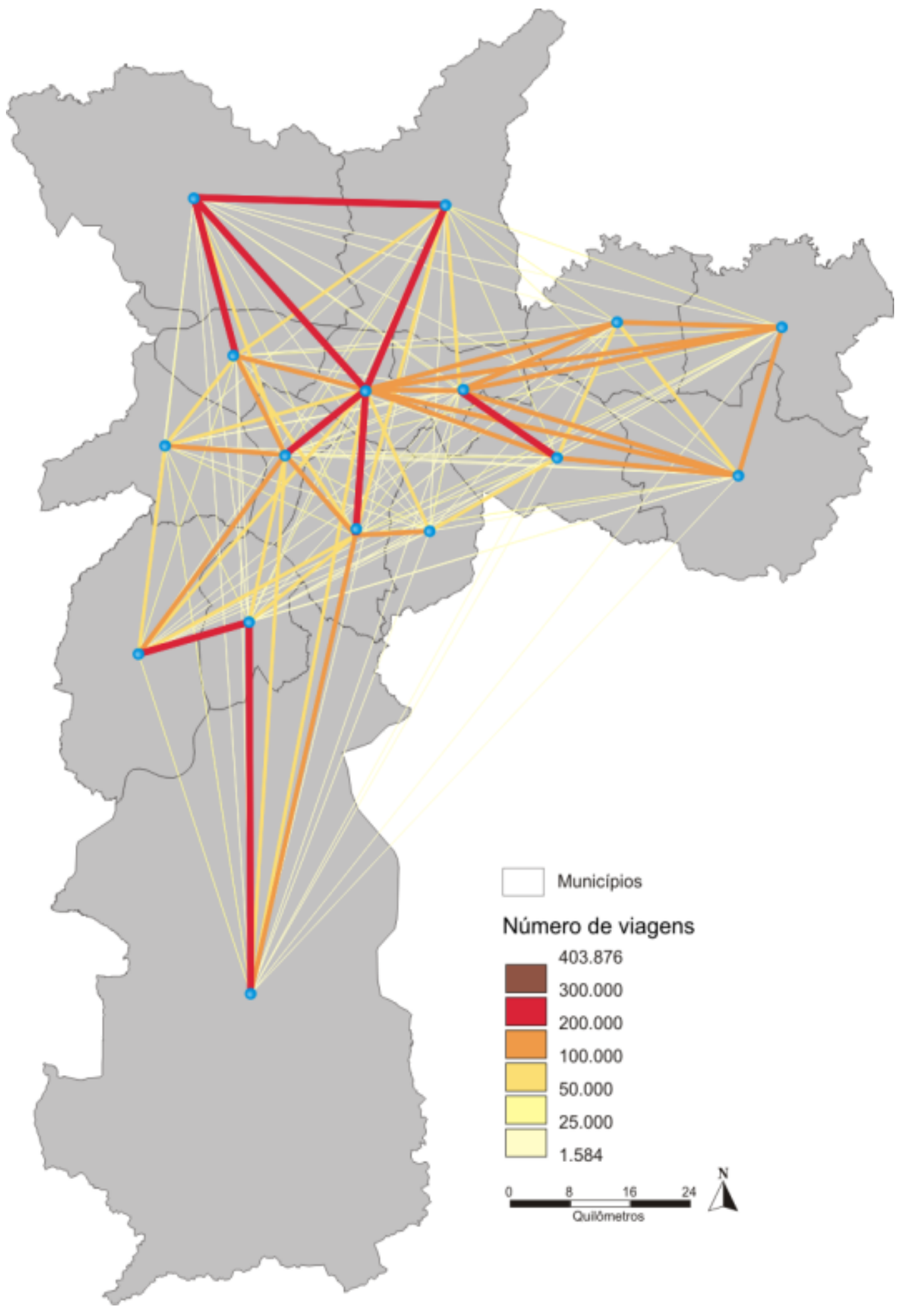

Fonte: Companhia do Metropolitano de São Paulo - METRÔ. Pesquisa Origem e Destino, 1997. Elaboração: André de Freitas Gonçalves 
Mapa 24 - Fluxo total de viagens por Regiões de São Paulo, 2007

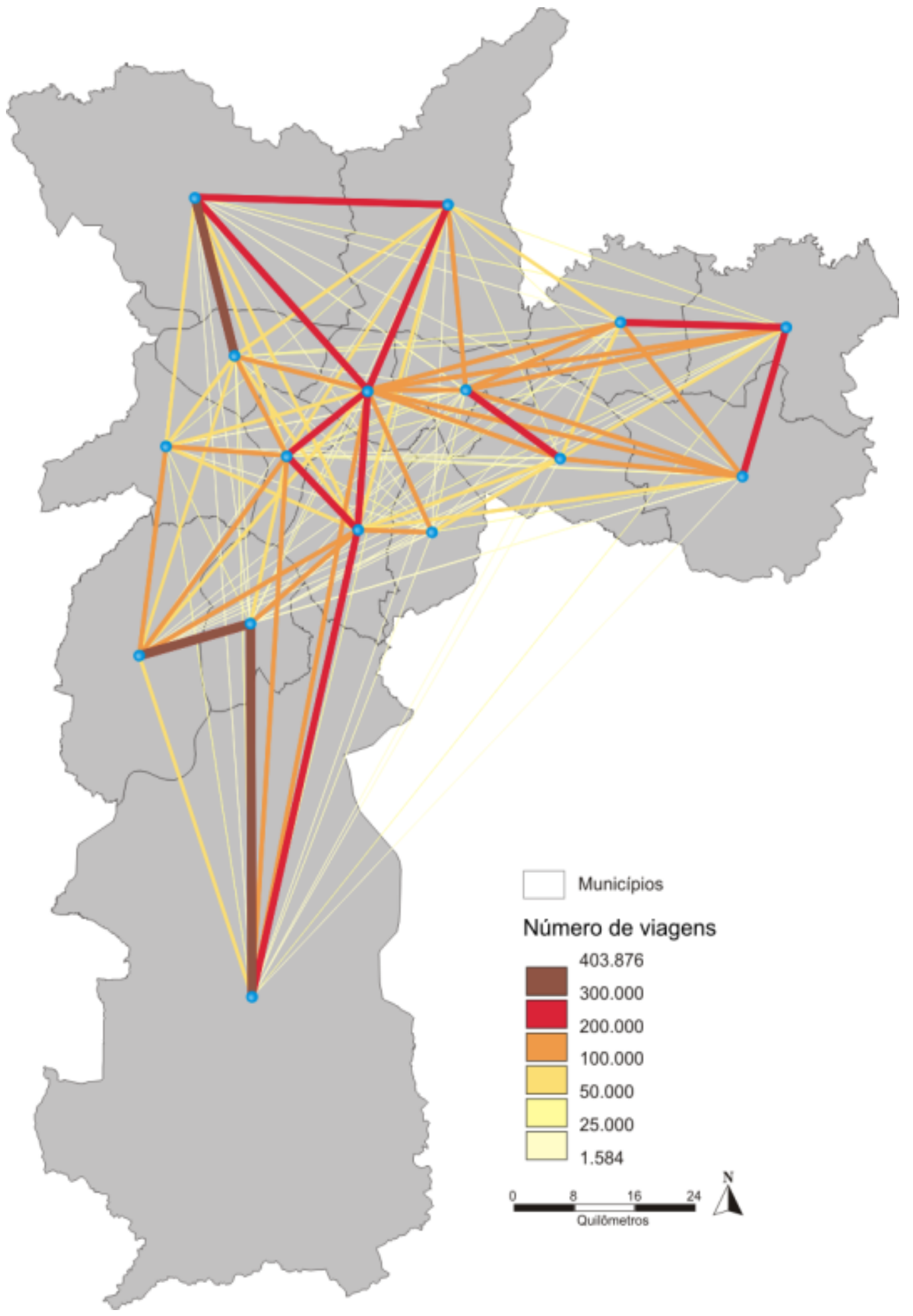

Fonte: Companhia do Metropolitano de São Paulo - METRÔ. Pesquisa Origem e Destino, 2007. Elaboração: André de Freitas Gonçalves 
Comparando com o mapa de fluxos de viagem de 2007, há praticamente a mesma configuração, contudo, os fluxos ganham densidade em várias regiões, sobretudo as periféricas. No mapa de 2007, existe uma faixa (ou classe) na legenda que não aparece no mapa de 1997, representando o maior fluxo de viagens para as ligações entre as regiões de Pirituba e Barra Funda, Campo Limpo e Santo Amaro, e Grajaú e Santo Amaro. Em segunda ordem, temos o aumento do fluxo entre as regiões de Grajaú e Vila Mariana, Vila Mariana e Pinheiros, e duas ligações especificamente periféricas, entre São Mateus e Itaquera, e Itaquera e Penha. Esse resultado nos mostra que mudanças significativas ocorreram na estrutura urbana da cidade, como o crescimento demográfico nas áreas periféricas, o que justifica a densidade de fluxos partindo dessas áreas. Isso se confirma quando analisamos a variação total do número de viagens no período de 1997 a 2007, registrando aumento efetivo em áreas periféricas e diminuição em áreas centrais. No mapa seguinte, observamos essa variação entre as regiões da cidade e notamos que os mesmos confirmam os mapas anteriores com os fluxos mais densos em destaque.

Existem vários aspectos da mobilidade urbana que podem ser trabalhados utilizando as Pesquisas de Origem e Destino e outras pesquisas. Contudo, cabe aqui ressaltar alguns pontos que nos ajudem a identificar os maiores movimentos que ocorrem na cidade, no seu espaço intramunicipal, a fim de compreender a circulação das pessoas, pois esse simples ato é responsável pela animação do espaço geográfico, por sua luminosidade, mas também sua ausência pode significar opacidade e depressão. Ele nos ajuda a enxergar as estruturas mais dinâmicas da cidade, os pontos mais atrativos que condensam as atividades fundamentais da vida humana, como estudar, trabalhar, passear, exercer atividades culturais e de lazer, comprar, entre outras.

Como resultado, temos a confirmação sim de que a cidade continua muito concentrada em termos de emprego e localização de serviços gerais, porém, existem movimentos recentes que apontam para outras localidades que não são as tradicionais centralidades, aquelas formadas na área consolidada. Há sim movimentos que apontam para uma metrópole que não para de crescer, mas não mais como antes, com a explosão demográfica. Agora cresce de outro modo, se desenvolvendo, criando e recriando espaços de moradia e de trabalho, traçando novas relações com seu entorno próximo - essas relações com localidades (municípios) circundantes. A metrópole ganha corpo e o que era periférico passa a ser central. 
Mapa 25 - Variação do número de viagens por Regiões do Município de São Paulo, 1997/2007

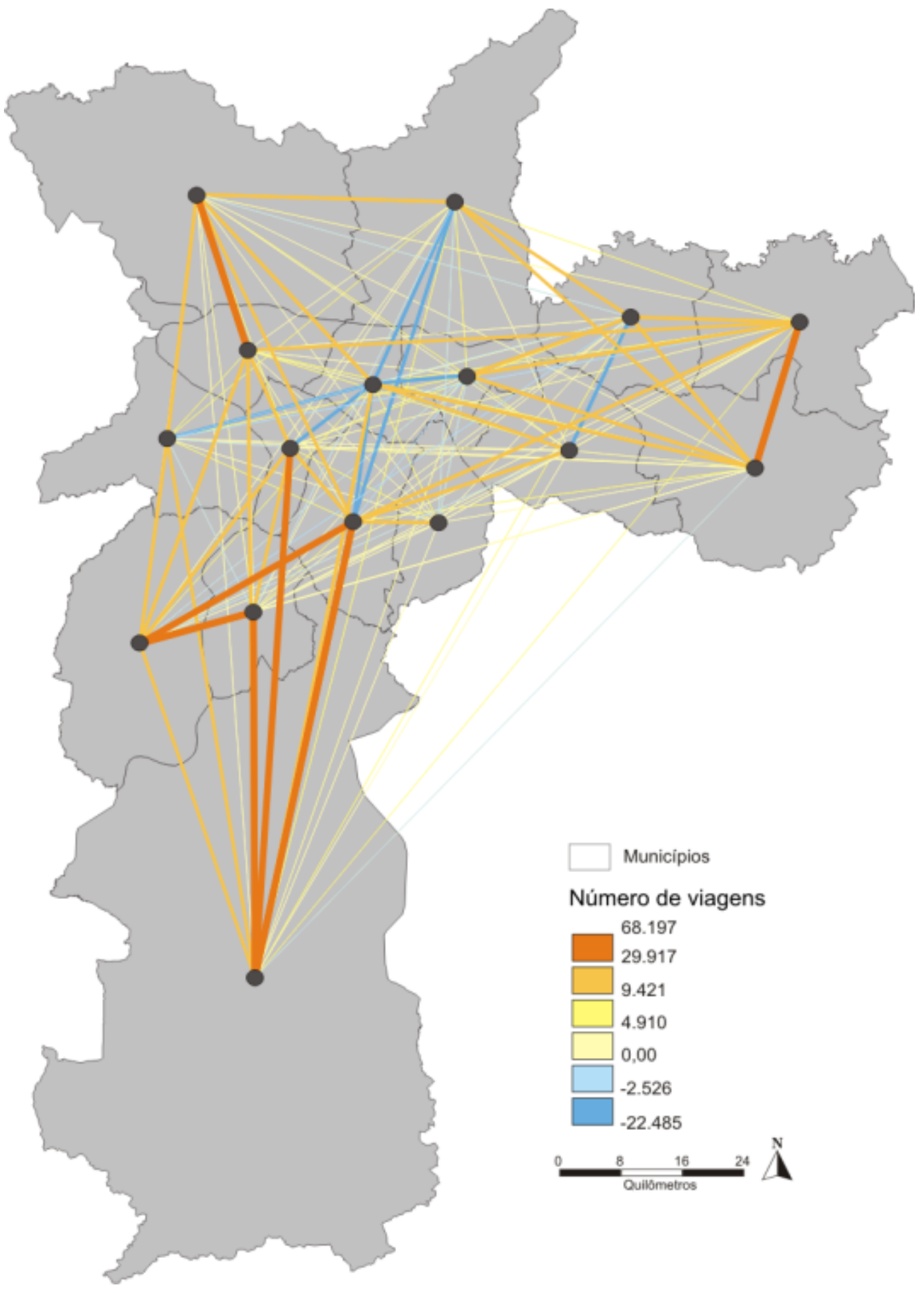

Fonte: Companhia do Metropolitano de São Paulo - METRÔ. Pesquisa Origem e Destino, 1997 e 2007.

Elaboração: André de Freitas Gonçalves Observação: quando se refere à Companhia do Metropolitano de São Paulo, padronizar optando por uma das formas: Metrô ou METRO. 


\section{Modelização gráfica da cidade de São Paulo}

Voltaremos a alguns pontos do diagnóstico para ressaltar as principais características e processos que ocorrem na cidade e apontar como isso marca o seu território. Começando por um aspecto que não se formou como tema específico: as áreas de proteção ambiental da cidade. Seus parques e áreas verdes, destinadas à população ou à preservação ambiental são de fundamental importância no cotidiano das pessoas que vivem na cidade.

São Paulo é uma grande cidade que ainda tem em seu território grandes porções de florestas e matas. Possui ainda dois grandes reservatórios de água (as represas Guarapiranga e a Billings) que formam uma enorme área de manancial que cobre a zona sul da cidade. Sua importância não é particularidade da capital, mas também da região metropolitana. Por isso, esta área é protegida por leis de diferentes tipos e criadas em diferentes instâncias.

Um elemento novo nesse quadro é à criação da Rodovia Mário Covas, o Rodoanel. A rodovia circunda a cidade de São Paulo, corta sua zona sul, passa por cima das represas, e futuramente, com a conclusão da obra, cortará a face norte da cidade onde existe outra importante floresta: o Parque da Cantareira. Como formas de compensação ambiental e principalmente para conter o avanço ou a ocupação ao seu redor, foram criados parques naturais em volta da rodovia, e estão planejados tantos outros. Leis municipais como o zoneamento e a criação de áreas de proteção ambiental (APA) tem o mesmo fim, inibir a ocupação da área.

Com a forte expansão da área urbanizada da cidade as áreas verdes e principalmente a área de mananciais sofrem forte pressão. Isso aconteceu durante décadas e alcançou tal estágio que se tornou um grande problema. Por exemplo, temos o distrito municipal mais populoso, o Grajaú, completamente dentro da área de proteção de mananciais. Essa área abriga um contingente populacional muito grande e, portanto, conta com uma série de serviços públicos fundamentais que, como um círculo vicioso, só faz atrair mais moradores. Com isso temos o conflito instalado: dar condições dignas de habitação, com serviços de transporte, saúde e educação de qualidade e que supra as demandas locais, e ao mesmo tempo, é preciso pensar como preservar e proteger o ambiente em meio a tamanho contingente populacional que ocupou a área de maneira precária.

Essas ações e processos estão representados nos próximos dois mapas. 


\section{Mapa 26 - Proteção ambiental, 2012}

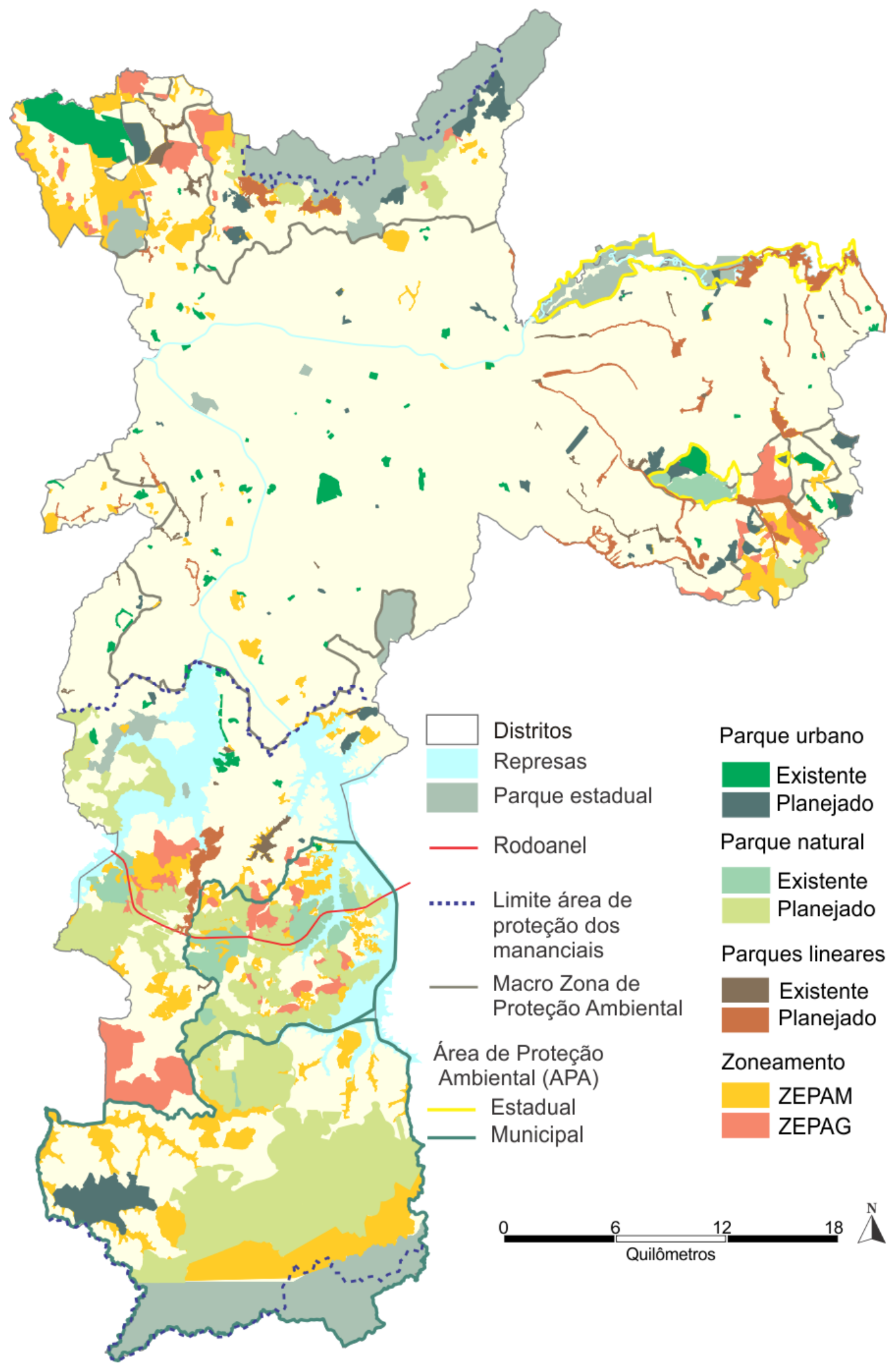

Fonte: Secretaria Municipal do Verde e Meio Ambiente (SVMA); Secretaria Municipal de Desenvolvimento Urbano (SMDU).

Elaboração: André de Freitas Gonçalves, 2012.

Nota: ZEPAM - Zona Especial de Proteção Ambiental; ZEPAG - Zonas Especiais de Produção Agrícola 


\section{Mapa 27 - Mancha da área urbanizada}
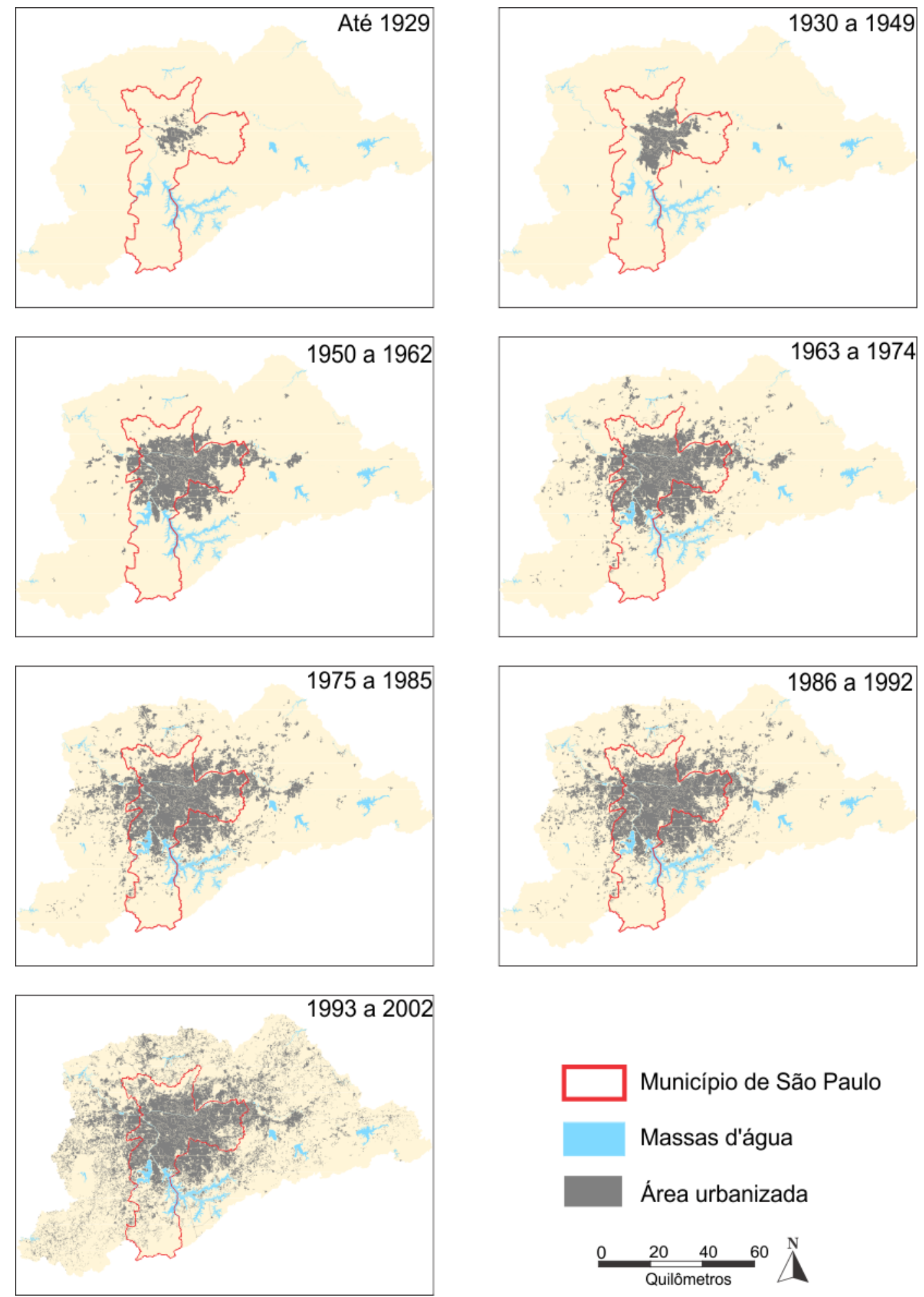

Fonte: Empresa Paulista de Planejamento Metropolitano (Emplasa).

Mapa de Expansão da Área Urbanizada da Região Metropolitana de São Paulo, 2002/2003.

Elaboração: André de Freitas Gonçalves 
Outro aspecto importante que devemos retomar é o fluxo total de passageiros de outros municípios da região metropolitana que se dirige à cidade de São Paulo, uma vez que, sua proximidade e com um sistema de transporte metropolitano interligado, favorece os deslocamentos intermunicipal. Alguns municípios vizinhos de São Paulo são chamados de cidade dormitório, pois a maior parte de seus moradores trabalha na cidade de São Paulo. Cidade dormitório ou não, o movimento pendular é característico da região metropolitana. As pessoas foram em busca de condições de moradia acessíveis às suas condições socioeconômicas. Como podemos observar no mapa seguinte, apresentando o fluxo total de viagens produzidas identificamos os principais fluxos. Esses são traçados e ligam os grandes municípios, os maiores da região. Podemos notar os dois maiores, Guarulhos que é o segundo maior município da região em termos populacionais, e Osasco é o quinto maior. Um segundo grupo de municípios em destaque é formado pela região do Grande $\mathrm{ABC}^{55}$, Santo André, São Bernardo do Campo e Diadema, com fluxos menores São Caetano do Sul e Mauá.

\section{Mapa 28 - Viagens produzidas pelos municípios da Região Metropolitana de São Paulo, 2007}

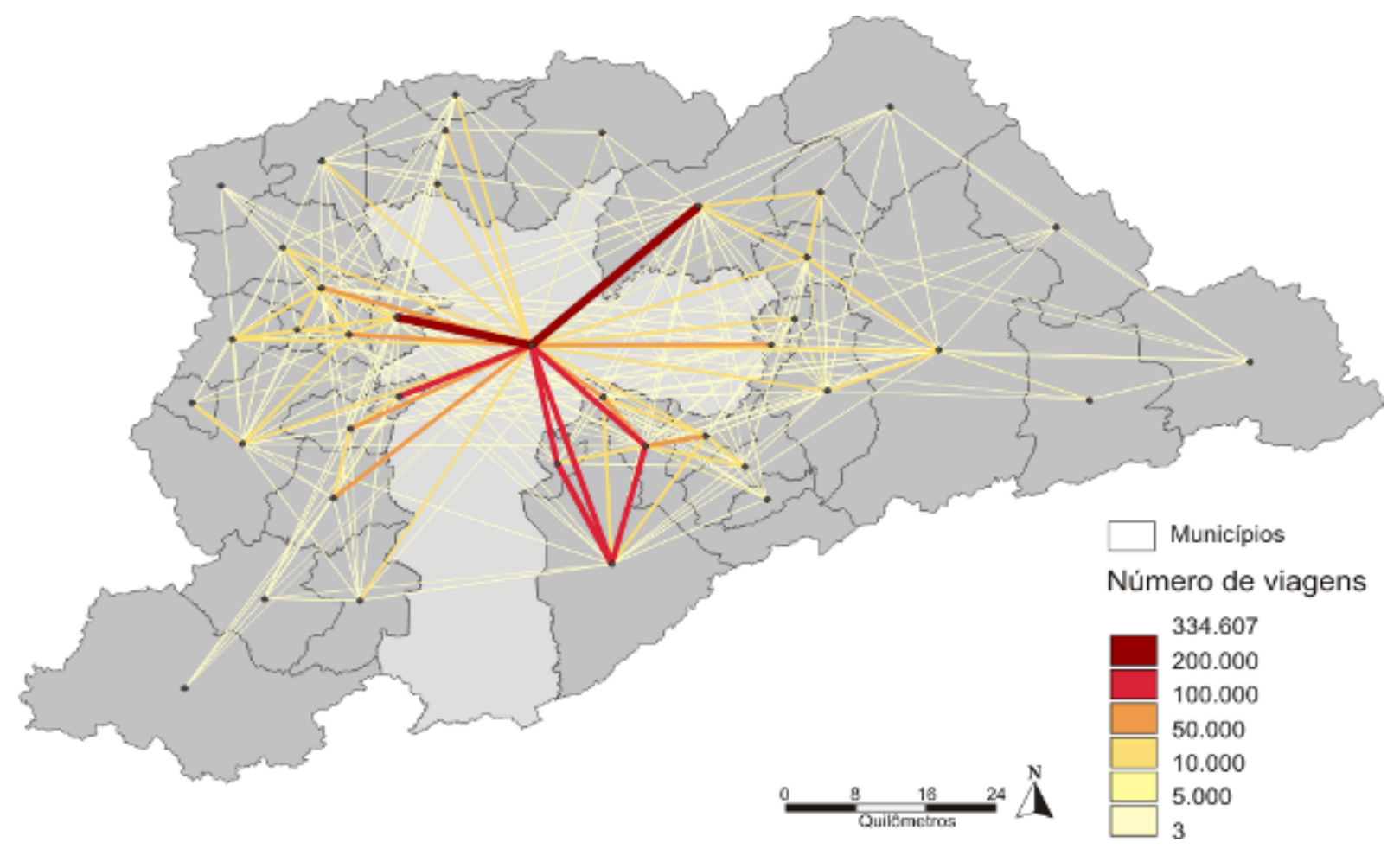

Fonte: Companhia do Metropolitano de São Paulo - METRÔ. Pesquisa Origem e Destino, 2007. Elaboração: André de Freitas Gonçalves

\footnotetext{
${ }^{55}$ Grande ABC aqui tratamos como sendo os municípios de Santo André, São Bernardo do Campo, São Caetano do Sul, Diadema, Mauá, Ribeirão Pires e Rio Grande da Serra.
} 
Considerando o limite administrativo da cidade e somando as condições apresentadas acima, com forte presença no cotidiano da cidade de pessoas vindas de três pontos principais, a saber, Guarulhos, Osasco e Grande ABC, temos a seguinte representação da cidade abaixo. Está dentro de um retângulo e utilizaremos esta forma para montar um modelo base para os demais.

\section{Figura 10 - Limite de São Paulo}

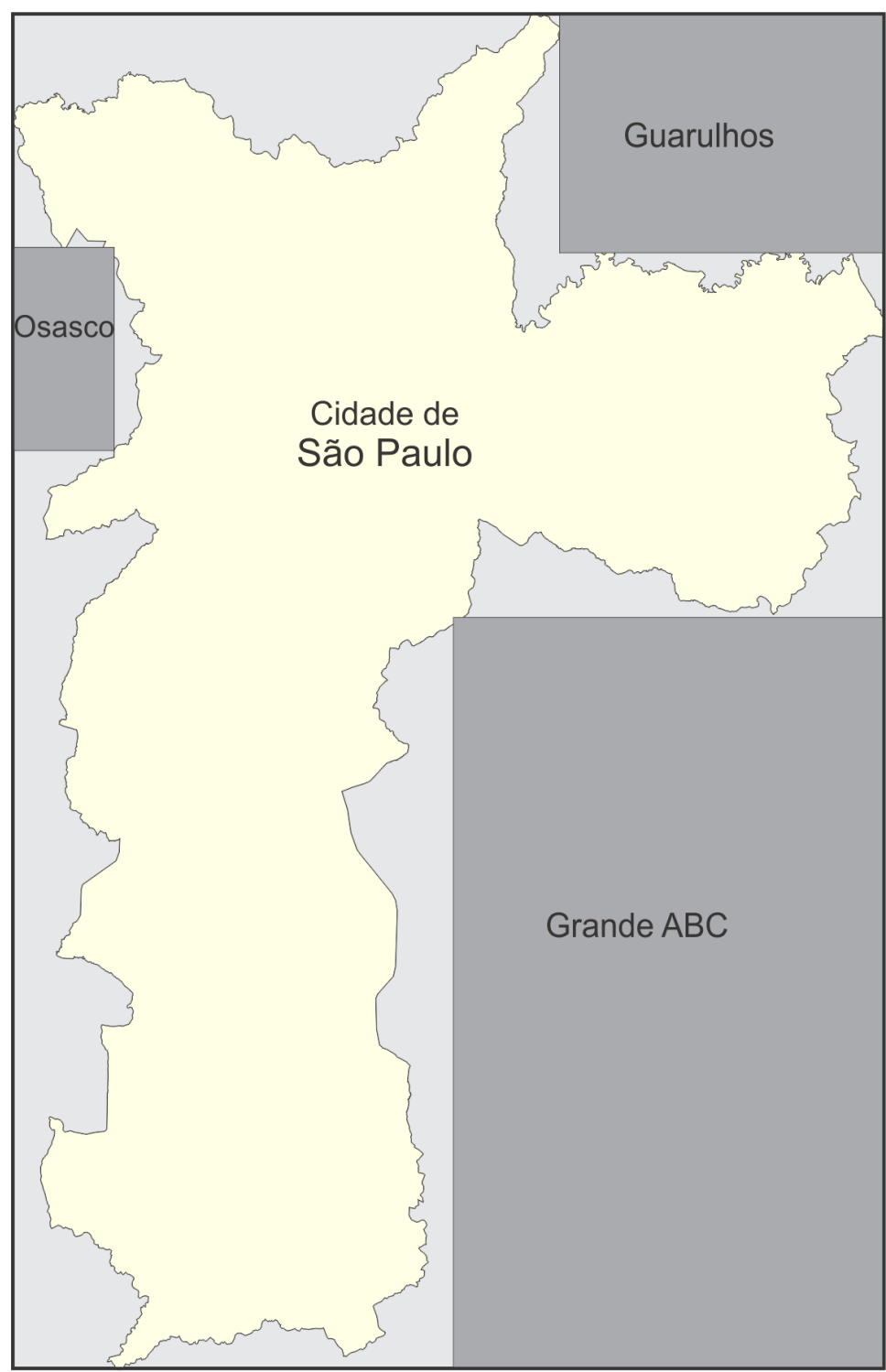

Elaboração: André de Freitas Gonçalves, 2012.

Nota: Aqui Grande ABC congrega os municípios de Santo André, São Bernardo do Campo, São Caetano, Diadema, Mauá, Ribeirão Pires e Rio Grande da Serra. 


\section{Os limites}

Iniciando a construção do modelo da cidade de São Paulo, criamos um modelo base, utilizando a "malha" administrativa ou limites administrativos e adicionamos três elementos importantes que são os municípios de maior interação. Se pegarmos a forma de retângulo, da figura anterior, e passarmos para um quadrado, temos o seguinte resultado:

\section{Figura 11 - Limite}

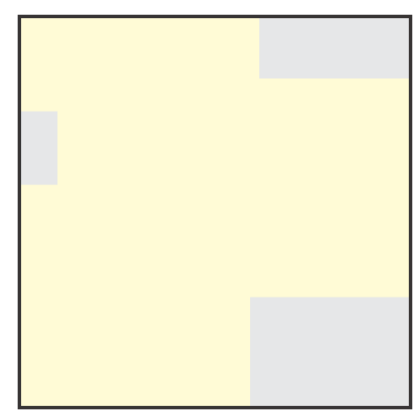

\section{Barreiras}

O segundo aspecto da estruturação do território de São Paulo são características físicas de suma importância para sua sobrevivência como um sistema, onde cada subsistema (ou partes) deve funcionar bem para o todo funcionar de maneira adequada ou da maneira que se espera. São quatro elementos representados que chamamos de barreiras. São eles: Grandes áreas verdes, constituídos por grandes parques estaduais: Parque da Cantareira ao norte, no leste, por onde passa o rio Tietê, temos o Parque Ecológico do Tietê onde coincide com uma Área de Proteção Ambiental (APA) chamada Várzea do Rio Tietê e no extremo sul temos o Parque da Serra do Mar, com uma extensão de 315 mil hectares que passa por 15 municípios e cobre boa parte da serra que separa o planalto do litoral; depois temos as duas represas: a Guarapiranga e a Billings, importantes fontes de água para região metropolitana; a linha tracejada representa o limite da área de proteção dos mananciais, isso para o sul e norte da cidade e ao leste representa o limite da APA e por fim temos o elemento ao sul da cidade entre o limite de proteção dos mananciais e o parque da Serra do Mar que chamamos de área de proteção, pois como vimos anteriormente incide sobre ela uma enormidade de leis de proteção, regulação, restrição etc., com o objetivo de proteger o ambiente de áreas verdes, florestas e principalmente lugar fonte de água para o sistema metropolitano. Com a 
construção do Rodoanel houve uma emergência em se criar parques naturais a fim de segurar a ocupação em seu arredor. Assim temos a configuração seguinte:

\section{Figura 12 - Barreira}

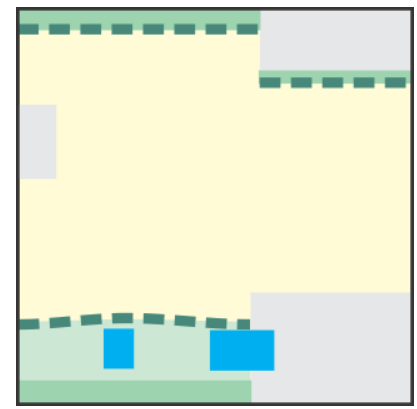

\section{Rede}

Destacamos no conjunto denso e complexo de redes e nós existentes na cidade esse dois grupos apresentados na figura seguinte. O primeiro grupo representado por uma linha de cor preta e com espessura mais fina são as principais vias da cidade, considerando sua relação com os demais processos transformadores em curso. Não se trata aqui de vias de maior circulação ou aceitando qualquer tipo de classificação viária existente. Por tanto temos as Marginais do Rio Pinheiros e do Rio Tietê, o primeiro a oeste e o segundo ao norte. Esses são os principais eixos da cidade em termos econômicos e de circulação. Depois a leste temos a Avenida do Estado, segue o rio Tamanduateí que passa pela região central da cidade e se liga a região do $\mathrm{ABC}$. Ligando o centro ao extremo leste temos uma linha horizontal que é a Radial Leste e por fim, no extremo Leste, temos a Avenida Jacu Pêssego que liga a Rodovia Ayrton Senna ao norte com o Rodoanel ao sul junto com as rodovias que levam ao porto de Santos. A ligação sul é realizada por uma extensão da avenida até o município de Mauá que depois se conecta a Avenida Papa João XXIII e posteriormente ao Rodoanel. Como dissemos, esse conjunto de rede é de suma importante para o desenvolvimento econômico da cidade e é responsável por transformações atuais e como possibilidade de mudança (principalmente no eixo Tamanduateí e Jacu Pêssego). O segundo grupo é formado por um conjunto de rodovias estaduais e uma federal que faz a ligação regional, do interior do Estado de São Paulo com o porto de Santos e também desse porto com o restante do país. No sentido noroeste a linha de espessura grossa representa duas rodovias, Anhanguera e Bandeirantes, que são as principais 
ligações com o interior do estado. A oeste temos a rodovia Castelo Branco, com ligação ao interior do estado sentido oeste, ligando com o interior do estado do Paraná. No sentido sudoeste temos a principal rodovia do país, a Rodovia BR 116, cuja extensão cruza o Brasil. Ela tem início na cidade de Fortaleza no Ceará, nordeste do país, e termina em Jaguarão no Rio Grande do Sul. Ao passar por São Paulo ganha dois nomes: Rodovia Régis Bittencourt no sentido sudoeste e no sentido nordeste Rodovia Presidente Dutra além da Rodovia Ayrton Senna. No sentido norte, temos a Rodovia Fernão Dias ligando ao estado de Minas Gerais. Ao sul as rodovias que levam ao litoral e ao porto de Santos temos as rodovias Imigrantes e Anchieta e no sul, com uma forma horizontal, está representado parte do Rodoanel, a rodovia que interligará todas as demais rodovias que passam pela região metropolitana de São Paulo.

\section{Figura 13 - Rede}

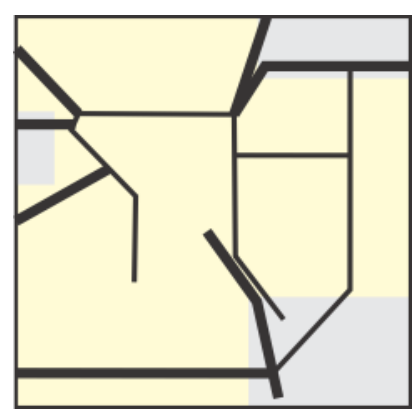

\section{Centralidade}

Como apresentamos no capítulo sobre dinâmica urbana, centralidade aqui tem características distintas da definição clássica. Acrescentamos o poder de gestão territorial ou de controle do território. Adicionamos as ideias de Corrêa (1996) quando trata dos centros de gestão do território, onde aponta que as metrópoles exercem controle sobre as atividades que estão fora de seus limites com a justificativa de que as atividades de planejar, conceber e dirigir são exercidas por empresas nela sediada.

O centro de gestão do território caracteriza-se, em realidade, por ser um centro onde tomam-se decisões e fazem-se investimentos de capital que afetam direta e indiretamente amplo espaço. Controlam assim a organização espacial de um dado espaço, influenciando a gênese e a dinâmica produtiva, 
o nível de empregos diretos e indiretos, os impostos, a mobilidade demográfica, as transformações no uso do solo e na paisagem, assim como a política local... (CORRÊA, 1996, p. 25).

Definimos quatro níveis de centralidade para cidade. O primeiro nível representa as centralidades hegemônicas da cidade, as maiores e mais fortes, constituídas pela centralidade da Sé, que é o núcleo central e histórico da cidade; a centralidade cujo símbolo é a Avenida Paulista; a centralidade Avenida Brigadeiro Faria Lima e a centralidade Avenida Eng. Luiz Carlos Berrini. No segundo nível estão as: centralidades Barra Funda, por suas transformações recentes e como área que ainda tem espaço físico para intervenções de porte e a centralidade Santo Amaro que sempre foi uma centralidade importante para a zona sul da cidade, mais que agora ganha importância com os desdobramentos recentes em termos de dinâmica imobiliária e expansão de atividades de serviços modernos em lugar de instalações industriais e galpões. No terceiro nível temos a centralidade de Itaquera que ainda está em formação. Destacaremos três importantes aspectos: o primeiro, diz respeito ao nó da rede de transportes criado em Itaquera, tornando-se referencia para uma ampla região, segundo, estão em andamento obras de grande porte e projetos em andamento como a instalação do Polo Institucional e Econômico de Itaquera e uma terceira característica é a Avenida Jacu Pêssego, que cruza a centralidade, e faz ligações ao norte na Rodovia Ayrton Senna e ao sul com o Rodoanel, que estão contribuindo para a elevação do nível econômico da região. Por fim temos o quarto nível, são caracterizadas como centralidades possíveis e fazem parte de uma visão de futuro, uma vez que não tem sua formação garantida. A primeira é a centralidade Vila Leopoldina, que passa por intensa atividade imobiliária já algum tempo e pode sofrer um processo de reestruturação por meio da operação urbana que ainda está em projeto. Ainda temos, do outro lado do rio Pinheiros, a criação do Polo Tecnológico do Jaguaré, que apesar de aprovado ainda não se concretizou. Essas ações podem colaborar para que essa centralidade se efetive. A segunda centralidade é a de Pirituba, que só se formará caso os projetos públicos sejam executados conforme previsto.

Mesmo em Itaquera, ainda que não haja certeza, há uma perspectiva de que a centralidade se forme efetivamente. Contudo é importante criar o quarto nível de centralidade e inserir Vila Leopoldina e Pirituba, pois essas se fazem necessárias. Mesmo sendo caracterizada como uma cidade policêntrica, São Paulo necessita de centralidades fortes que estejam além do entre rios (Pinheiros e Tietê) ou entre marginais. 
Voltando às centralidades hegemônicas gostaríamos de levantar a questão do esvaziamento econômico da região central da cidade, a Sé, como uma ideia ultrapassada sem fundamento. Mesmo com a migração de sedes de empresas, o centro continua exercendo um papel dinâmico na economia da cidade. Por isso foi alvo de investimentos em transporte nas últimas décadas. Os mais recentes são a construção da linha amarela do Metrô ligando a região da Luz com a zona oeste da cidade e o corredor de ônibus que liga o Parque Dom Pedro II ao Sacomã e posteriormente à zona leste da cidade, por meio da construção de um Monotrilho. Isto demonstra a importância contínua do centro antigo. Não existe, portanto "um abandono"; uma fuga de empresas. Trata-se da substituição de uma atividade econômica por outra. Em outras palavras, o que existe são antigas formas com novos conteúdos, e mesmo essas formas são constantemente alteradas para suprir necessidades específicas à função que passaram a exercer. Este processo pode ser exemplificado com o famoso caso do Banco de Boston, que ocupava um edifício na Rua Libero Badaró no centro antigo, e migrou para um edifício na Marginal do Pinheiros. Esse caso teve grande repercussão por existir por parte da Associação Viva o Centro, um esforço de segurar as empresas (grandes sedes) no centro antigo, mas não se trata de um esvaziamento ou suga, no edifício funciona agora o setor de contact center do banco e também do processamento de dados. Eles terceirizaram as atividades, hoje desempenhadas pela empresa Atento que faz uso das infraestruturas já implantadas na região central da cidade. (GONÇALVES, 2008). A migração de empresas e sedes de empresas para outras centralidades, como Paulista e depois Faria Lima e Berrini, não representam abandono. O que há é substituição de atividades e adequação a novas exigências. Também o movimento que fez surgir essas centralidades não se caracteriza pela linearidade que nos induz a cronologia dos fatos. Em resumo, guardadas suas especificidades elas fazem parte de um mesmo movimento e exercem suas funções de forma complementar.

Figura 14 - Centralidade

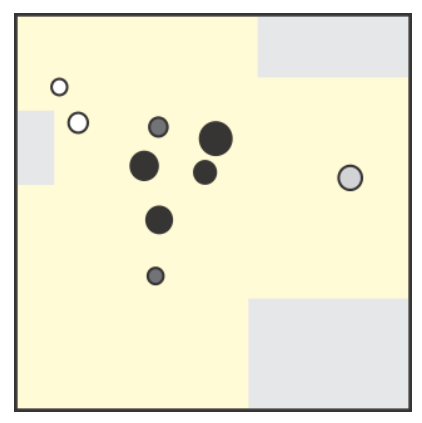




\section{Eixo}

O que chamamos simplesmente de eixo, trata-se da Marginal do Pinheiros um longo conjuntos de avenidas que margeiam o rio Pinheiros, indo da zona sul da cidade até a oeste, é formado por atividades de serviços de alta tecnologia, novos edifícios comerciais, shopping centers freqüentado por pessoas de alta renda, áreas residenciais de alto padrão, onde existe uma forte transformação imobiliária, tanto residencial quanto comercial. As setas indicam sua expansão, para ambos os sentidos, contudo ela ocorre de forma mais recente e com mais intensidade no sentido sul, com grandes empreendimentos sendo entregues e tantos outros em construção.

Figura 15 - Eixo

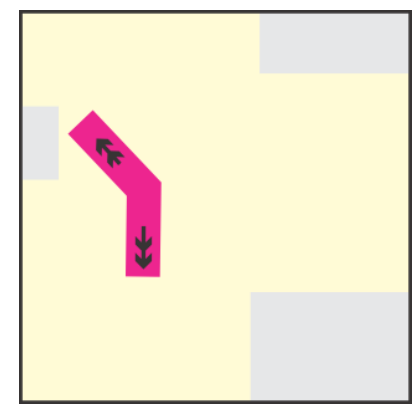

\section{Indústria}

Como foi visto o setor de atividade industrial ainda é importante para cidade de São Paulo e estrutura seu território de forma clara. Contribui para uma diversificação de atividades e da sustentação para uma gama de serviços que são direcionados especificamente para esse setor. A Indústria foi historicamente marcada por uma localização clássica ao longo das ferrovias e posteriormente das rodovias. Isso fica claro na sua distribuição representada com a figura seguinte. As orlas ferroviárias que passam próximas a Marginal do Tietê e seguem pelo Rio Tamanduateí, cercadas pela Avenida do Estado, dão a forma básica de sua distribuição. A diferenciação das cores indica a densidade que é maior na área do Brás e segue pouco abaixo no eixo Tamanduateí.

Na zona oeste temos a região da Lapa como concentração histórica e ao sul Santo Amaro sentido Jurubatuba. Os sinais de positivo e negativo se referem à variação no número de emprego formal, entre os anos de 1996 e 2006, tendo como fonte a Rais, (dados trabalhados no capítulo de dinâmica produtiva), e como podemos verificar, os pontos negativos se concentram nas áreas tradicionais e de maior densidade de atividade industrial. 
Por outro lado temos os pontos positivos indicando regiões periféricas da cidade, localizadas próximas a grandes vias de circulação que ganharam número de empregos no período analisado. Em destaque, uma área na região central da cidade trata-se do Brás com sua atividade têxtil.

\section{Figura 16 - Indústria}

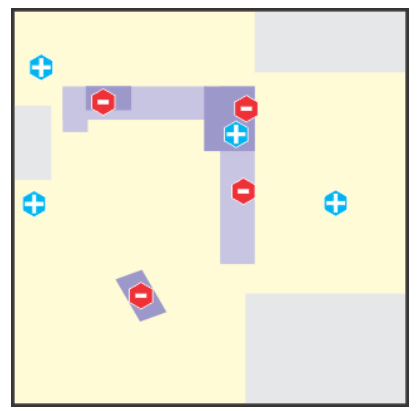

\section{Densidade}

Representamos aqui como densidades uma porção da cidade onde estão localizadas as principais concentrações de emprego, os serviços modernos ou de alta tecnologia; áreas de forte comércio, onde estão as sedes das empresas, das multinacionais, os bancos, os serviços especializados, áreas residenciais nobres etc. Nesta área o preço do metro quadrado, tanto residencial quanto comercial, é extremamente alto. Este perímetro é permeado de um emaranhado de redes de diferentes tipos: fibra óptica, redes de telecomunicação, de transporte. O metrô se concentra principalmente nesta área, que recebe um número exorbitante de fluxos de pessoas, mercadoria, dinheiro e informação. É a área da cidade mais animada, mais viva, mais consolidada e mais dinâmica. É esse tipo de densidade que procuramos representar em três níveis.

Figura 17 - Densidade

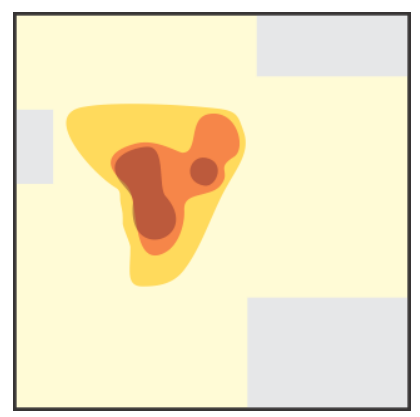

\section{Fluxo}


Utilizando este tipo de representação, procuramos destacar os principais emissores de pessoas e a direção de seu fluxo principal. Ele indica de maneira geral o polo emissor. Com isso temos Guarulhos a nordeste, entorno de São Miguel e São Mateus no leste, a região do Grande ABC no sudeste, o entorno de Grajaú e Campo Limpo no sul, Osasco no oeste e, por fim, a noroeste tem o entorno de Pirituba. Destas regiões partem os principais fluxos de pessoas em direção à área mais densa da cidade; mais concentrada.

\section{Figura 18 - Fluxo}

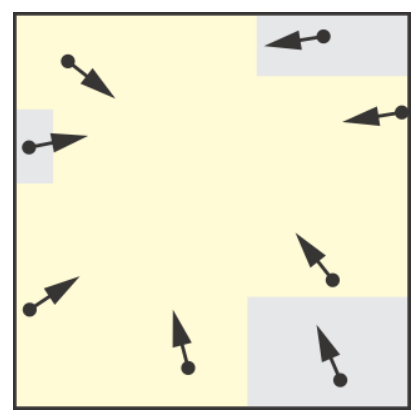

\section{Pressão}

Representamos aqui a pressão que a expansão da área urbanizada ainda hoje exerce sobre áreas de proteção ambiental, principalmente nas porções norte e sul da cidade. Como já apontamos anteriormente, são áreas sob um arcabouço legislativo variado que procura dar conta de proteger uma importante área de mananciais ao sul da cidade e com grandes dimensões de florestas e matas, assim como ao norte temos o Parque da Cantareira, porção da Serra da Canteira.

\section{Figura 19 - Pressão}

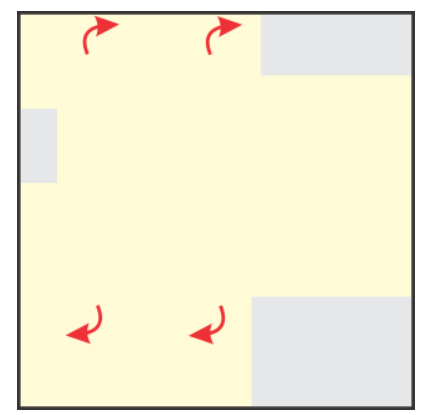




\section{Conflito}

É preciso lembrar que a vida na cidade envolve disputas, choques e conflitos. O número de atores é elevado e os interesses são múltiplos. Conviver não é uma tarefa das mais simples e num universo de 11 milhões de habitantes a coisa fica ainda pior. O processo de participação quando da criação do Plano Diretor da cidade é um indicativo disso. Houve diversas reuniões, de todo tipo, em diferentes lugares e em diferentes momentos para se debater o que queremos para a cidade. Nem todos demonstraram contentamento com os resultados obtidos nesses encontros.

O que procuramos representar aqui são dois tipos de conflitos que ocorrem na cidade, entre tantos outros. O primeiro, que aparecem em dois pontos da cidade, é o conflito entre habitação de baixa renda versus habitação de alta renda. Localizamos um no centro histórico da cidade em função do projeto Nova Luz e das obras ou projetos de revitalização do centro que acabam por expulsar os antigos moradores de baixa renda. O outro local é na Avenida Águas Espraiadas, como ponto de criação da Operação Urbana Águas Espraiadas, local que envolveu forte luta por moradia social ou de baixa renda. Como se não fosse suficiente o processo de valorização imobiliária brutal que acontece no centro expandido da cidade, o que torna a moradia inacessível para pessoas de baixa renda, existem processos que procuram expulsar as pessoas que ainda permanece.

O outro caso marcado em verde ao sul da cidade é o conflito entre habitar versus preservação ambiental. Uma questão histórica que por vezes volta à tona quando surge algum fato novo, o que nesse caso, pode ser representado pela criação do Rodoanel. Procuram-se evitar uma influência negativa da rodovia com a criação de parques naturais em seu entorno. De qualquer forma existe na área de mananciais da cidade um enorme contingente de moradores e não há por parte do poder publico uma ação efetiva de investimentos para adequação das condições sociais e ambientais da região.

Figura 20 - Conflito

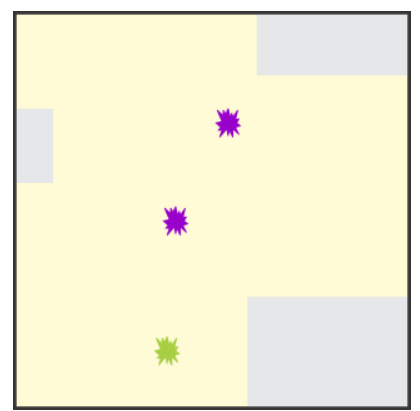


Em seguida apresentamos os elementos de composição da modelização gráfica e por fim o modelo gráfico da cidade de São Paulo.

Figura 21 - Elementos de composição da modelização gráfica
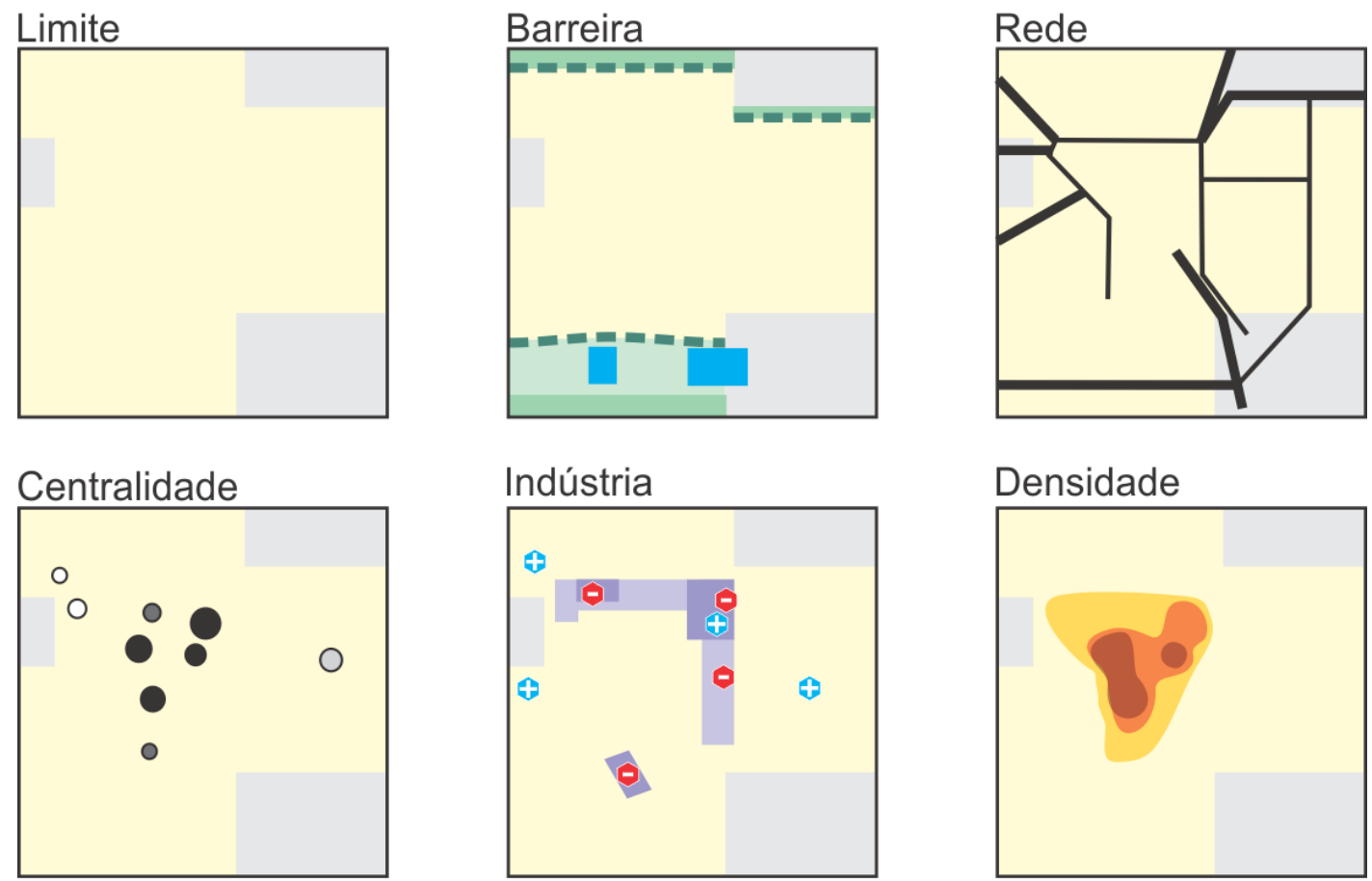

Fluxo
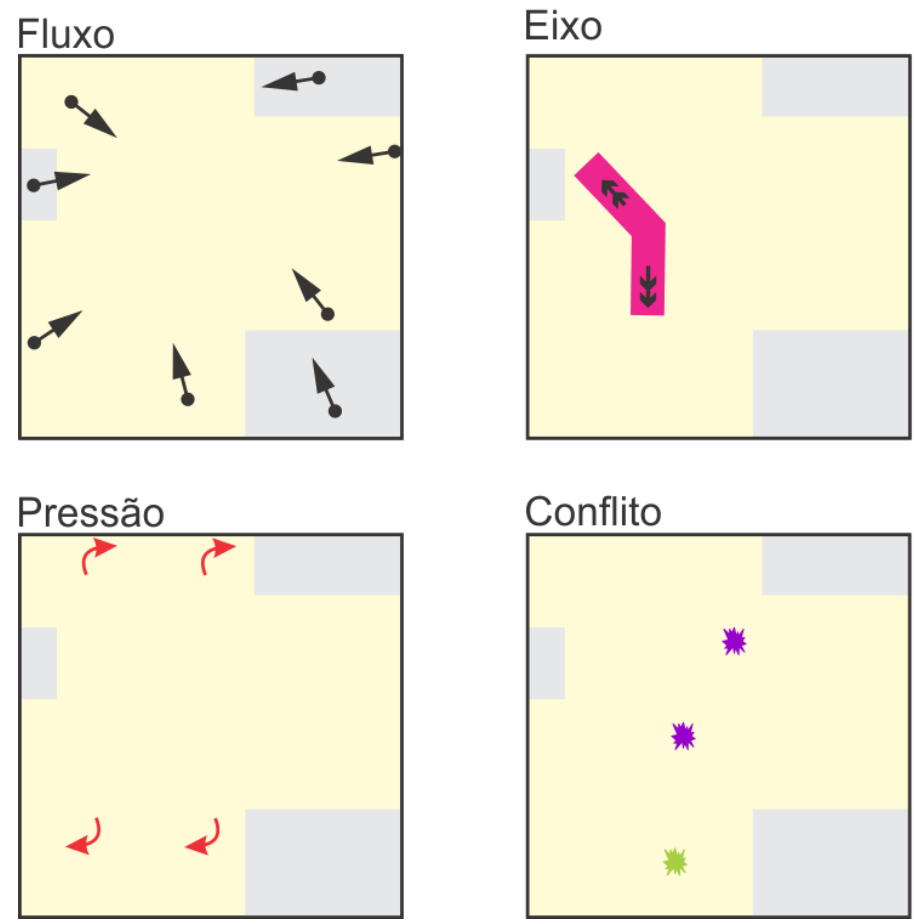

Elaboração: André de Freitas Gonçalves, 2012. 
Figura 22 - Modelo da cidade de São Paulo

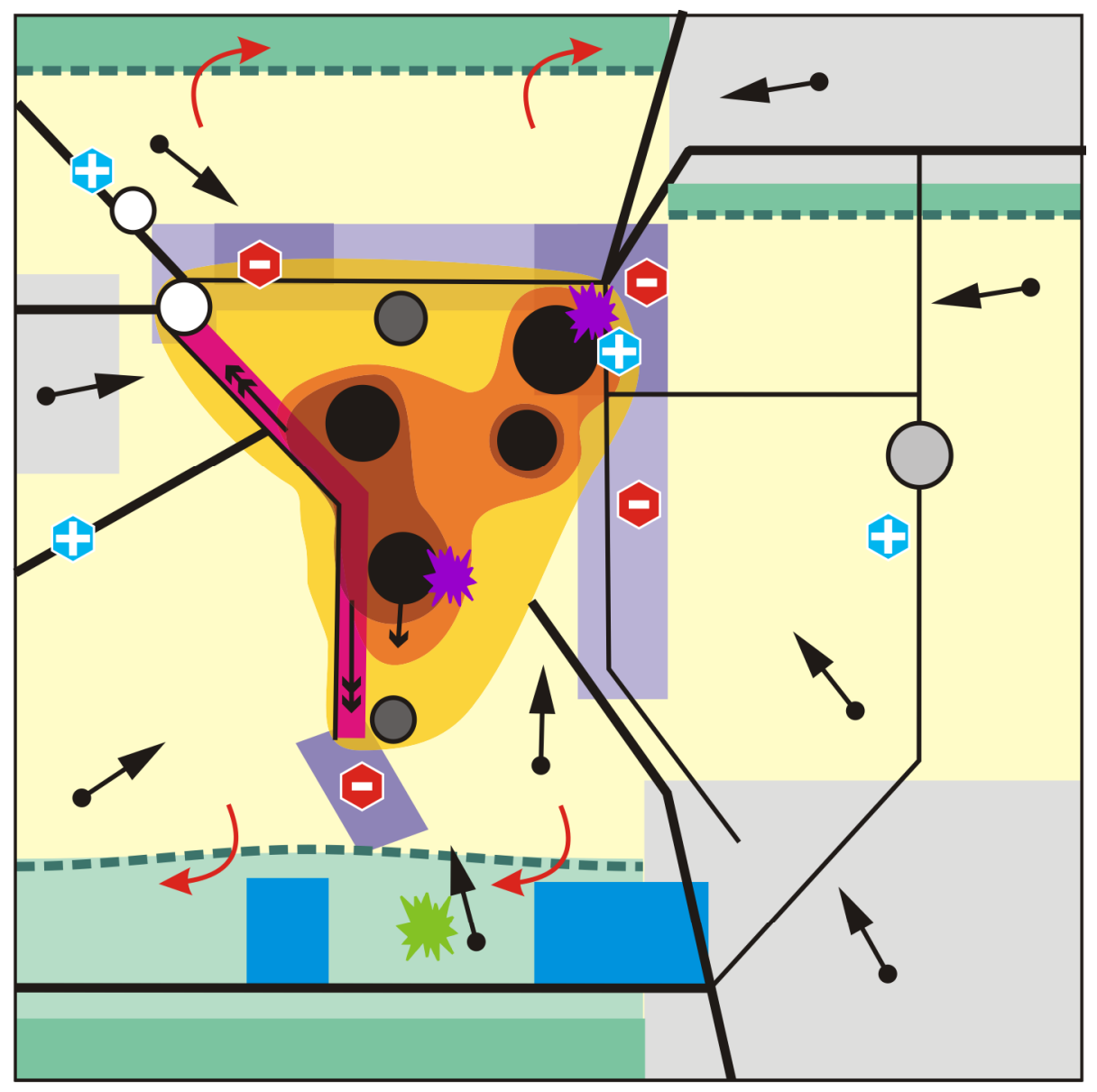

\section{Barreira}

- -- Limite de proteção

Rede

\section{Grande área verde} Área de proteção Represas

Centralidade
Primeira ordem
Segunda ordem
Terceira ordem
Quarta ordem

Atividade industrial

- Ganho (emprego formal)

- Perda (emprego formal)

Alta densidade

Baixa densidade

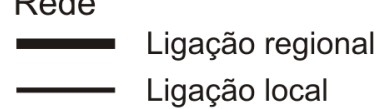

Densidade econômica

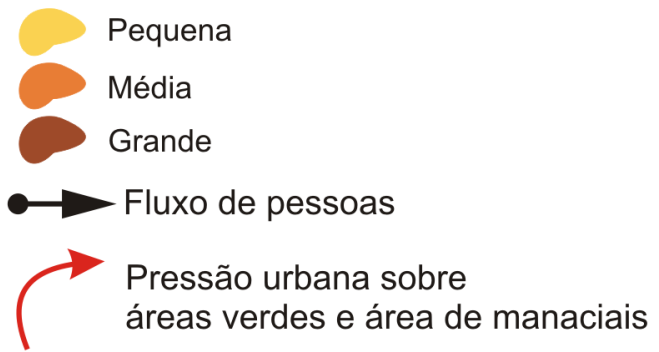

\section{Conflito}

Habitação de baixa renda $X$

Habitação de alta renda

Habitar X Proteção ambiental

Eixo de desenvolvimento

Elaboração: André de Freitas Gonçalves, 2012. 


\section{Considerações finais}

Após pesquisa e organização das ideias que permeiam a avaliação de território e posteriormente o mesmo com a coremática concluímos que ambos se complementam e fazem parte de um mesmo esforço que é compreender a organização do espaço geográfico e suas dinâmicas, pois durante a elaboração do diagnóstico da cidade de São Paulo e da elaboração das cartografias de base ou "temática", ficou claro a busca pelo entendimento e avaliação daquele território e que o ato de modelar as estruturas elementares do espaço que ali se enxergava era uma ação com vista no futuro daquele território (um ato prospectivo), uma vez que ao analisar o território em movimento observamos os possíveis caminhos que este pode tomar e quais os resultados podemos esperar.

Aplicando a avaliação territorial na cidade de São Paulo, desenvolvemos um diagnóstico seletivo e não de forma extensa e exaustiva, em busca dos pontos fortes, de atores e processo significativos, que expliquem a estruturação de seu território de maneira clara e objetiva, ao mesmo tempo, o resultado dessa investigação é de fundamental importância para a elaboração de modelos dessas estruturas e posteriormente uma modelização gráfica da cidade. A ação que cria o modelo nos ajuda a limpar e selecionar as informações utilizadas, e entender o movimento do território, o que também possibilita completar parte da avaliação que é ter uma visão de futuro; uma análise prospectiva. Ambas se complementam.

A coremática ou modelização gráfica é uma corrente teórica, tem um entendimento do que é Geografia e de como exercê-la, e também é uma metodologia de representação gráfica, o que amplia intensamente a possibilidade de críticas. Toda a forma de representação gráfica ou cartográfica tem suas limitações, e é por essa razão que existem várias. Há de se reconhecer essas limitações e definir quais são as mais apropriadas para representar tal o qual aspecto da realidade. Não se pode perder de vista que uma representação gráfica é sempre uma representação da realidade e não ela em si, logo essa representação tem prazo de validade. Independente de nossa divergência teórica e reconhecendo as limitações, a modelização gráfica é um avanço na forma de conhecer e representar a organização do espaço geográfico. Onde a simplificação das formas gráficas é necessária para que se possa apreender a complexidade daquilo que elas representam. 
Sobre o resultado da modelização gráfica da cidade de São Paulo podemos observar que, apesar de conter formas geométricas simples, o conjunto contém um número significativo de formas. Talvez um pouco mais do recomendado, poderíamos representar os processos de uma forma gráfica mais enxuta, contudo foi onde conseguimos chegar. Ainda assim os principais processos, indicados pelo diagnóstico, que se desenvolvem na cidade, estão representado e sua combinação é bem apreendida.

A conclusão sobre a avaliação territorial da cidade de São Paulo, como está presente no decorrer do diagnóstico aponta para um território dinâmico que tem sua complexidade aumentada fortemente no período recente; com concentração de atividade econômica muito forte; com atração de novas atividades de alta tecnologia; com um mercado imobiliário (residencial e comercial) dinâmico. Por outro lado, mesmo que reconhecidamente policêntrica é preciso descentralizar mais, pois como mostra os indicadores de demanda por transporte, os fluxos só cresceram nos últimos anos. Com a melhora na economia as pessoas tendem a circularem mais, elevando o índice de mobilidade. Em regiões periféricas as condições não são as melhores em decorrência das dificuldades cotidianas em circular pela cidade e pela precariedade de alguns assentamentos. Os conflitos estão presentes na função da cidade que lhe é mais cara o habitar. Como forma de melhorar as condições dos moradores e de ativar economicamente a cidade alguns propõem o adensamento da região central da cidade, isto devido a crítica ao esvaziamento da região central (SANDRONI, 2004, 2006; BONDUKI, 2011).

Como se verificou com os dados econômicos e do censo demográfico, essa tarefa, de maneira intencional ou não, já foi cumprida. Processo que já se mostrava efetivo faz algum tempo.

O quadro agudo de crise, identificado há mais de uma década na área central de São Paulo, costuma ser associado ao suposto "esvaziamento" econômico e demográfico da região e a um processo de "abandono" por parte de agentes públicos e privados. Contudo, uma verificação preliminar dos processos urbanísticos envolvidos, do histórico das políticas públicas que afetaram o centro, dos dados de atividade econômica e sua distribuição territorial nos permite questionar em grande medida a validade desses pressupostos (ROLNIK, CAMPOS, e NAKANO, 2004, p. 154) 
Contudo, o resultado pode não ter sido o esperado por alguns. Os distritos mais centrais da cidade passaram a registrar taxas de crescimento positivas, quebrando uma tendência que vinha desde os anos de 1980. Economicamente o centro mostra que se mantém forte e ativo, porém é de conhecimento geral que os preços de aluguel e de moradia no centro expandido da cidade são elevados, e foram aumentados a cargo da crescente procura por esses bens, pela facilidade do crédito, uma boa condição econômica etc. É preciso uma investigação maior, mas podemos apontar que essas condições não são as melhores para que pessoas de baixa renda, essas que precisam se deslocar até o centro para trabalhar, possam obter uma moradia em uma região melhor localizada. A valorização escalonar dos apartamentos nessa região é um impedimento prático ao acesso de pessoas de baixa renda. É preciso pensar em formas; estratégias que garantam uma variedade de classes de renda ocupando a região central para que não ocorra uma elitização.

De uma forma geral a cidade de São Paula avança em alguns pontos, mas para quem tem problemas graves e historicamente não resolvidos deveria reagir de maneira mais profícua. Não estamos nos referindo diretamente ao poder administração municipal, e sim de maneira ampla, de todas as instâncias de poder e da sociedade como um todo. Para resolver problemas tão grandes como o tamanho de São Paulo é preciso unir forças e saber para onde direcioná-la. 


\section{Referências bibliográficas}

ANELLI, R. L. S. Redes de mobilidade e urbanismo em São Paulo: das radiais/perimetrais do Plano de Avenidas à malha direcional PUB. Arquitextos n. 82.00. São Paulo, Portal Vitruvius, mar. 2007. Disponível em: <http://www.vitruvius.com.br/revistas/read/arquitextos/07.082/259 >. Acesso em: 10 jun. 2012 .

ÁLVAREZ, J. G. La coremática y la nueva geografia regional francesa. Ería, número 45, pag. 5-35., 1998. Disponível em:

http://www.unioviedo.es/reunido/index.php/RCG/article/view/1264 Acesso em: 15/10/2011.

ARANTES, O. Uma estratégia fatal. A cultura nas novas gestões urbanas. In: ARANTES, O.; MARICATO, E.; VAINER, C. A cidade do pensamento único: desmanchando consensos. Petrópolis, Vozes, 2000.

BAENINGER, R. São Paulo e suas migrações no final do século 20. São Paulo, São Paulo em Perspectiva. Fundação SEADE, vol. 19, n. 3, p. 84 -96m,jul/set. 2005.

BENKO, G. Mundialização da economia, metropolização do mundo. Revista do Departamento de Geografia, n. 15, p. 45-54, 2002.

BESSA, C. V. O setor de serviços às empresas. In: EMURB/CEBRAP. (org.). Caminhos para o centro. São Paulo, 2004. Disponível em: <http://www.centrodametropole.org.br/divercidade/numero2/caminhos/13Bessa.pdf $>$ Acesso em: 05.abr.2007.

et al. Território e desenvolvimento econômico. In: COMIN, A. et al.(org.). Metamorfoses paulistanas: atlas geoeconômico da cidade. São Paulo, Coedição SMDU/CEBRAP/Imprensa Oficial do Estado de São Paulo/Editora UNESP, 2012.

BONDUKI, N. O modelo de desenvolvimento urbano de São Paulo precisa ser revertido. Estudo Avançados. São Paulo, vol.25, n. 71, jan./abr. 2011. 
BRANDÃO, C. O desenvolvimento das metrópoles na economia contemporânea. In: Dieese; Ceset. (org.). O trabalho no setor terciário: emprego e desenvolvimento tecnológico. São Paulo, Dieese; Campinas,Ceset, 2005.

BRUNET, R. La composition des modèles dans l'analyse spatiale. L'Espace Géographique, $\mathrm{n}^{\circ} 4,1980$, p. $253-65$.

. La carte, mode d'emploi. Paris, Fayard/RECLUS, 1987, 269 p.

La carte-modèle et leschorèmes. Mappemonde, n. 04, 1986, p. 2-6.

. Evaluation des territoires et cartomatique. In:BRUNET, R. (dir.), THÉRY, H.; PHILIPPE, W. (coord.). Réseau cartomatique des départements et territoires d'outre-mer pour l'information et l'aide à la décision: rapport à $M$. le Ministre des Départements et Territoires d'Outre-Mer. Montpellier, Maison de laGéographie, 1990, 76 p. Disponível em: <http://horizon.documentation.ird.fr/exl-doc/pleins_textes/divers08-01/010010797.pdf>

- Les sentiers de la géographie: un peu d'air au coin du bois, Espace géographique. Tome 25, n. 1, 1996. p. 23-32.

. Des modèles en géographie ? Sens d'une recherche. Bulletin de la Sociéte de Géographie de Liège, n. 2, 2000, p. 21-30. Disponível em:

<http://www.mgm.fr/ARECLUS/page_auteurs/Brunet3.html> Acesso em: 05. abr. 2012.

Le déchiffrement du Monde. Belin, 2001, 402 p.

.Pour une pratique raisonée et rationelle de la représentation des territoires. Simpósio sobre aRepresentaçãodos Territórios, realizado em Turim, pela Região do Piemonte, 2006. Disponível em: <http://www.mgm.fr/ARECLUS/page_auteurs/Brunet4.html〉. Acesso em: 05. abr. 2012.

CAIADO, A. S. C. Dinâmica socioespacial e a rede urbana paulista. São Paulo, São Paulo em Perspectiva, Fundação SEADE, vol. 9, n.3, p. 54-61m,jul/set. 1995.

; RIBEIRO, T.F.F.; AMORIM, R. L. C. Políticas neoliberais e reestruturação produtiva, 2004. In:POCHMANN, M. (org.) Reestruturação produtiva: perspectivas de desenvolvimento local com inclusão social. RJ, Vozes, 2004.

CARDOSO, C. E.de P. Mobilidade em São Paulo - aimportância dos fatores socioeconômicos - XIX ANPET - Associação Nacional de Pesquisa e Ensino em Transportes, Recife, 2005. 
CARLOS, A. F. A. Espaço-tempo na metrópole. São Paulo, Contexto, 2001. São Paulo: dinâmica urbana e metropolização. Revista Território, Rio de Janeiro, ano VII - n' 11, 12 e 13 - set./out. 2003.

COMIN, A. et al. (org.). Metamorfoses paulistanas: atlas geoeconômico da cidade. São Paulo, Coedição SMDU/CEBRAP/Imprensa Oficial do Estado de São Paulo/Editora UNESP, 2012.

CORDEIRO, H. K. A “cidade mundial” de São Paulo e o complexo corporativo do seu centro metropolitano. In: SANTOS, M. et al. O novo mapa do mundo: fim de século e globalização. São Paulo, Hucitec/Associação Nacional de Pós-Graduação e Pesquisa em Planejamento Urbano e Regional, 1993.

CORRÊA, R. L. A rede urbana. São Paulo, Ática,1993.

.Os centros de gestão do território: uma nota. Revista Território, Rio de Janeiro, Ano I, n. I, 1996.

.Redes,fluxos e territórios: uma introdução. In: AGB, III Simpósio Nacional de Geografia Urbana. Rio de Janeiro, Anais, AGB, p. 31, 1993.

DELAMARRE, A. La prospective territoriale, Datar / La Documentation française, 154 p. La prospective territoriale. Territoires en mouvement. AutorAliette DelamarreEditoraDocumentation Française, 2002

DIAS, L. C. Os sentidos da rede: notas para discussão. In: DIAS, L. C.; SILVEIRA, R. L. L. de. (org.) op. cit.,2005, p. 11-28.

DINIZ, C.; DINIZ, B. P. C. A região metropolitana de São Paulo: reestruturação, reespacialização e novas funções. In: Caminhos para o Centro. Estratégias de desenvolvimento para a região central de São Paulo. CEBRAP, 2004. 
DUTENKEFER, E. Representações do espaço geográfico: mapas dissimétricos, anamorfoses e modelização gráfica. Dissertação de Mestrado em Geografia, Faculdade de Filosofia, Letras e Ciências Humanas, Universidade de São Paulo, São Paulo, 2010.

ECKERT, D. Évaluation prospective des territoires, RECLUS / La Documentation française, 1996, $256 \mathrm{p}$.

FONSECA, F. P. A inflexibilidade do espaço cartográfico, uma questão para a Geografia: análise das discussões sobre o papel da Cartografia. Tese de Doutorado em Geografia, Faculdade de Filosofia, Letras e Ciências Humanas, Universidade de São Paulo, São Paulo, 2004.

FOURNY, M. C. e DENIZOT, D. A prospectiva local, um modo de produção e governança, Confins [Online], postagem online em 22 jul. 2010. Disponível em: <http://confins.revues.org/6502 ; DOI : 10.4000/confins.6502>. Acesso em: 13 abr. 2012.

FREIRE, C. T.; ABDAL, A.; BESSA, V.. Conhecimento e tecnologia: atividades industriais e de serviços para uma São Paulo competitiva. In: COMIN, A. et al.(org.). Metamorfoses paulistanas: atlas geoeconômico da cidade. São Paulo, Coedição SMDU/CEBRAP/Imprensa Oficial do Estado de São Paulo/Editora UNESP, 2012.

FRÚGOLI JR., H. Centralidade em São Paulo: trajetórias, conflitos e negociações na metrópole. São Paulo, Cortez, Universidade de São Paulo, 2000.

.A questão das centralidades em São Paulo: o papel das associações de caráter empresarial. Revista de Sociologia e Política, Paraná, Universidade Federal do Paraná, jun. 2001, n. 16, p. 51-66.

GARCÍA ÁLVAREZ, J. La coremática y la nueva geografía regional francesa, Oviedo: Ería. Revista Cuatrimestral de Geografía, n. 45,1998, p. 5-35.

GIRARDI, E. P. Atlas da questão agrária brasileira. Qualificação (Doutorado em Geografia), Faculdade de Ciências e Tecnologia, Universidade Estadual Paulista, Presidente Prudente, 2007. 
GONÇALVES, A. de F. As empresas de contactcenter no território brasileiro e sua concentração na cidade de São Paulo. Trabalho de Graduação Individual. São Paulo, Departamento de Geografia, FFLCH-USP, 2008.

GOTTDIENER, M. A teoria da crise e a reestruturação socioespacial: o caso dos Estados Unidos. In: PRETECEILLE, E.; VALLADARES, L. (coords.). Reestruturação urbana: tendência e desafios. São Paulo, Nobel, 1990.

HALL, P. Cidade do amanhã. São Paulo, Perspectiva, 2007.

HARVEY, D. A produção capitalista do espaço. São Paulo,Annablume, 2005. Justiça social e a cidade. São Paulo,Hucitec, 1980.

LANGENBUCH, J.R.A estruturação da Grande São Paulo. Rio de Janeiro, IBGE, 1971.

LEBORGNE, D.; LIPIETZ, A. Flexibilidade defensiva ou flexibilidade ofensiva: os desafios das novas tecnologias e da competição mundial. In: PRETECEILLE, E.; VALLADARES, L. (coords.). Reestruturação urbana: tendência e desafios. São Paulo, Nobel, 1990.

LENCIONI, S. Reestruturação urbano-industrial: centralização do capital e desconcentração da metrópole de São Paulo, a indústria têxtil. Tese de Doutorado, Departamento de Geografia, Faculdade de Filosofia, Letras e Ciências Humanas, Universidade de São Paulo, São Paulo, 1991.

. Cisão territorial da indústria e integração regional no Estado de São Paulo. In: GONÇALVES, M.F.; BRANDÃO C.A.; GALVÃO A.C. (org.). Regiões e cidades, cidades nas regiões. O desafio urbano-regional. São Paulo,Unesp, 2003, p. 465-75.

MARTINUCI, O. da S. Circuitos e modelos da desigualdade social intraurbana. Dissertação de Mestrado em Geografia, Faculdade de Ciências e Tecnologia, Universidade Estadual Paulista, Presidente Prudente, 2008.

MATTEO, M.; BESSA, V. C. As tendências atuais da subcontratação e as políticas de formação profissional no Brasil. São Paulo, CEPAL, 2001 (mimeo) 
MENEGATTO, M. S. M. Modelização gráfica do estado de Rondônia, Confins [Online],postagem online em 19 jun 2012. Disponível em: < http://confins.revues.org/7678 >. Acesso em: 03 jul. 2012.

MIYAZAKI, V. K. Um estudo sobre o processo de aglomeração urbana: Álvares Machado, Presidente Prudente e Regente Feijó. Dissertação de Mestrado em Geografia, Faculdade de Ciências e Tecnologia, Universidade Estadual Paulista, Presidente Prudente, 2008, $172 \mathrm{f}$.

NOBRE, E. Reestruturação econômica e território: expansão recente do terciário na marginal do rio Pinheiros. Tese de Doutorado, Faculdade de Arquitetura e Urbanismo, Universidade de São Paulo, 2000.

ODDY, M. Reestruturação industrial, pós-fordismo e novos espaços industriais: uma critica. In: PRETECEILLE, E.; VALLADARES, L. (coords.). Reestruturação urbana: tendência e desafios. São Paulo, Nobel, 1990.

PADUA, R. F. de. Implicações socioespaciais da desindustrialização e da reestruturação do espaço em um fragmento da metrópole de São Paulo. São Paulo, FFLCH, 2008.

Produção e consumo do lugar: espaços de desindustrialização na reprodução da metrópole. Tesede Doutorado emGeografia Humana,Faculdade de Filosofia Letras e Ciências Humanas, Universidade de São Paulo, 2012.

PANIZZA, A. de C. Imagens orbitais, cartas e coremas: uma proposta metodológica para o estudo da organização e dinâmica espacial - aplicação ao município de Ubatuba, litoral norte, Estado de São Paulo, Brasil. Tese de Doutorado em Geografia, Faculdade de Filosofia, Letras e Ciências Humanas, Universidade de São Paulo, São Paulo, 2004.

PRADO JÚNIOR, C. O fator geográfico na formação e no desenvolvimento da cidade de São Paulo -"Geografia", ano I, n. 3, São Paulo, 1935; e "Revista do Arquivo Municipal de São Paulo", ano II, vol. XIX, São Paulo, 1936.

PRETECEILLE, E.; VALLADARES, L. (coords.). Reestruturação urbana: tendência $e$ desafios. São Paulo, Nobel, 1990.

ROLNIK, R. São Paulo. São Paulo,Publifolha, 2003.

.; FRUGOLI Jr., H. Reestruturação urbana da metrópole paulistana: a Zona Leste como território de ruptura e permanências. Cadernos Metrópole Desigualdade e Governança. São Paulo, v.1, n. 6, p. 55-84, 2001. 
.; CAMPOS, C. M., e NAKANO K. Dinâmicas dos subespaços da área central de São Paulo. In: Caminhos para o Centro: Estratégias de desenvolvimento para a região central de São Paulo. EMURB, Prefeitura do Município de São Paulo, CEBRAP, CEM, 2004, pp.123-158.

.;KLINTOWITZ, D. Mobilidade na cidade de São Paulo. Estudo Avançados. São Paulo, vol.25, n. 71, São Paulo, jan./abr. 2011.

SANDRONI, Paulo. A dinâmica imobiliária da cidade de São Paulo: esvaziamento, desvalorização e recuperação da região central. Em: Prefeitura de São Paulo. Caminhos para o Centro: estratégias de desenvolvimento para a região central de São Paulo, São Paulo: EMURB, Prefeitura do Município de São Paulo, CEBRAP, CEM, 2004. Cap. 12 pp. 366 380.

. Alternativas para o transporte nas metrópoles mundiais. In: PROENçA, Heloísa. (Org.). Visões da Metrópole - Depoimentos sobre transporte e urbanismo para o PITU RMSP 2025. 1 ed. São Paulo: FUPAM / Imprensa Oficial do Estado de SP, 2006.

SANTOS, M. A natureza do espaço: técnica e tempo, razão e emoção. São Paulo, Edusp, vol. 4,2004 .

.Da totalidade ao lugar. São Paulo, Editora da Universidade de São Paulo, 2008.

.Metrópole corporativa fragmentada: o caso de São Paulo. São Paulo, Secretaria de Estado da Cultura, 1990.

.Por uma outra globalização: do pensamento único à consciência universal. São Paulo,Record, 2000.

SASSEN, S. As cidades na economia mundial. São Paulo, Studio Nobel, 1998. . The Global City: New York, London, Tokyo.PrincitonUniversity Press, 1991. 
.; ROOST, F. A cidade: local estratégico para a indústria de entretenimento. Espaço e debates. São Paulo, Núcleo de Estudos Regionais e Urbanos, n. 41, p. 66-74, 2001.

SÃO PAULO (Município). Secretaria Municípal de Desenvolvimento Urbano. Departamento de Estatística e Produção de Informação. Informes Urbanos: Economia Paulistana mantém crescimento. n.5, jan. 2012.

Secretaria Municipal de Desenvolvimento Urbano. Departamento de Estatística e Produção de Informação. Informes Urbanos: O crescimento formal do emprego formal na cidade de São Paulo. n. 4, dez. 2011.

.Secretaria Municipal do Planejamento. Evolução do uso do solo nos anos 1990. São Paulo, Sempla, 2000.

Secretaria Municipal do Planejamento. Município em Mapas: Dinâmica Urbana. São Paulo, Sempla, 2006.

SILVA, A. B. As grandes empresas de consultoria, a produção de informações e os novos círculos de cooperação no território brasileiro. In: Anais do X Encontro de Geógrafos da América Latina. São Paulo, Universidade de São Paulo, 20 a 26 de março de 2005. CR-ROM.

. A contemporaneidade de São Paulo. Produção de informações e novo uso do território brasileiro. Tese de Doutorado, Departamento de Geografia, Faculdade de Filosofia, Letras e Ciências Humanas, Universidade de São Paulo, São Paulo, 2001.

SINGER, P. Desenvolvimento econômico e evolução urbana - análise da evolução econômica de São Paulo, Blumenau, Porto Alegre, Belo Horizonte e Recife. São Paulo, Nacional, 1968.

Migrações internas: considerações teóricas sobre seu estudo. In: SINGER, P. Economia política da urbanização. São Paulo, Brasiliense, 1973.

SMITH, N. Desenvolvimento desigual. Rio de Janeiro, Bertrand Brasil, 1988.

.Gentrificação, a fronteira e a reestruturação do espaço urbano. GEOUSP Espaço e tempo, São Paulo, n. 21, p. 15-31, 2007. 
SOJA, E. Geografias pós-modernas: a reafirmação do espaço na teoria social crítica. Rio de Janeiro, Jorge Zahar, 1993.

SOMEKH, N. Globalização e forma urbana: a intervenção urbanística na cidade de São Paulo. In: SANTOS, M. et al. O novo mapa do mundo: fim de século e globalização. São Paulo, Hucitec/Associação Nacional de Pós-Graduação e Pesquisa em Planejamento Urbano e Regional, 1993.

SOUZA, M. A. A. de. Território e lugar na metrópole: revisitando São Paulo. In: CARLOS, A.F.A.; OLIVEIRA, A.U. (orgs.). Geografias de São Paulo: a metrópole do século XXI. São Paulo, Contexto, v. 2, p. 21-50, 2004.

THÉRY, H. Modelização gráfica para a análise regional: um método, GEOUSP - Espaço e tempo, n. 15, p. 179-88, 2004.

; MELLO, N. A. de. Atlas do Brasil: disparidades e dinâmicas do território. São Paulo: Edusp, 2005.

.Chaves para a leitura do território paulista.In:Atlas Seade da economia paulista.

Disponível em:

<http://www.seade.gov.br/produtos/atlasecon/index.php?texto=mapa\&cap_cod= 11>, 2006, Seade.

. Modelos gráficos da competitividade paulistana. In: COMIN, A. et al.(org.). Metamorfoses paulistanas: atlas geoeconômico da cidade. São Paulo. Coedição SMDU/CEBRAP/Imprensa Oficial do Estado de São Paulo/Editora UNESP, 2012.

THÉRY-MELLO, N. A. de. Conservação de áreas naturais em São Paulo. Estudo Avançados. São Paulo, vol.25, n. 71, jan./abr. 2011.

VASCONCELLOS, E. Circular é preciso, viver não é preciso: a história do trânsito na cidade de São Paulo. São Paulo, Annablume, 2000. 
.Mobilidade urbana e atividade econômica. In: COMIN, A. et al. (org.). Metamorfoses paulistanas: atlas geoeconômico da cidade.São Paulo, Coedição SMDU/CEBRAP/Imprensa Oficial do Estado de São Paulo/Editora UNESP, 2012.

WALDVOGEL, B.C. (Coord.). São Paulo Outrora e Agora: Informações sobre a população da capital paulista do século XIX ao XXI., São Paulo: Fundação Seade, 2004.

andredfg@yahoo.com.br 